क) 

'est date star ' 1 '

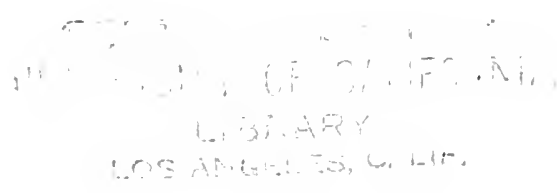



THE DEVELOPMENT OF FEDERAL RESERVE POLICY 



\title{
THE DEVELOPMENT OF FEDERAL RESERVE POLICY
}

\author{
BY \\ HAROLD L. REED \\ PROFESSOR OF BANKING AND FINANCE, WASHINGTON UNIVERSITY \\ SAINT LOUIS
}

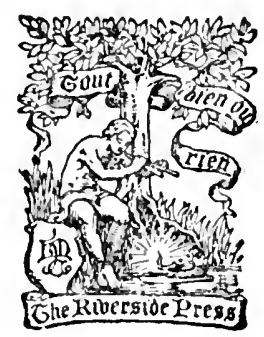

\author{
BOSTON AND NEW YORK \\ HOUGHTON MIFFLIN COMPANY
}

Cye zhiversioe press Cambrioge

1922 
COPYRIGHT, I922, BY HAROLD L. REED

ALL RIGHTS RESERVED

The Riucrsioe Pregs CAMBRIDGE - MASSACHUSETTS

FRINTED IN THE U.S.A. 


\section{PREFACE}

Owing to the unusual character of the period during which its policy has been developed, many misconceptions have become current regarding the nature and purpose of the Federal Reserve banking system. Some of these mis-

$\lambda$ conceptions are so far-reaching as to create serious dif-

* ficulties for its management. No central banking system can be administered efficiently in an atmosphere of prejudice and misunderstanding. The business public, in its appraisal of the system's management, must be led to apply the tests of sound principles of economics and finance rather than those merely of immediate, individual advantage. It, accordingly, has been the writer's endeavor to do what little his capacities permit to stimulate a proper spirit of inquiry regarding Federal Reserve matters.

It has appeared to the writer that a careful examination of the development of the reserve system could be made most opportunely by one not connected with its management. As a minor spur to the writer's efforts there has been the belief that no study offers superior opportunities for investigating the working of the principles of money and credit under contemporary conditions of business and industry. While the book was written for the general reading public, rather than for classroom purposes, it may serve as a sccond book to follow the reading of one of the elementary texts in college courses in Money and Banking.

On this occasion the writer would like to express his 
gratitude to those who have helped him to sustain his interest in finance and economics. Among these he would like to mention the names of Professor Kemmerer, of Princeton University; Professor Davenport, of Cornell University; Dean Joseph French Johnson, of New York University; Dean Turner, of New York University; Dean Gephart, of Washington University, now VicePresident of the First National Bank of St. Louis; Professor Willcox, of Cornell University; and Professor A. S. Johnson, at present a member of the editorial staff of the New Republic. Professor Allyn A. Young, of Harvard University, has been a constant source of inspiration. April 30, 1922. 


\section{CONTENTS}

I. The Working of the Regional Systeil I

II. Check Collections and Clearances under the Federal Reserve

III. State Bank Membership in the Federal ReSERVE

IV. Advances of Reserve Banks - Rediscounts

V. Direct Collateral Advances to Member BANkS

VI. The Develophent of the Trade Acceptaxce 105

VII. Agricultural Credit under the Federal ReSERVE

VIII. The Development of the Bank Acceptance

IX. The Open-Market Operations of Reserve Banks

X. Advances of Reserve Banks - Note Issues 205

XI. Advances of Reserve Banks - Deposits and Reserves

XiI. Federal Reserve Development, November, I9I4, TO DECEMBER, I9I6

Early Problems of Organization

XIII. Federal Reserve Development, Jayuary, i 917 , TO APRIL, I9I 7

Financial Preparation for lWar

XIV. Federal Reserve Development, May, 19i7, to November I I, I 9 I 8

War-Time Credit Expansion 
viii CONTENTS

XV. Federal Reserve Development, November i2, I)I 8 , to $\mathrm{MAY}$, I920 Tine Perion of Post-IVar Credit Expansion

XVI. Federal Reserve Develophent, May, igzo, to the Present Time

The Period of Business Reaujustment

INDEX 


\section{THE DEVELOPMENT OF}

FEDERAL RESERVE POLICY 



\section{THE DEVELOPMENT OF FEDERAL RESERVE POLICY}

CHAPTER I

THE WORKING OF THE REGIONAL SYSTEM

IN the matter of structure, organization, and administration, the most characteristic feature of the Federal Reserve banking plan is the system of district reserve banks. The regional system was also the most surprising outcome of the legislative planning which preceded the framing of the final provisions of the act. Since 1907 the question of banking reform had revolved about the idea of establishing, for the entire country, a single large and powerful institution which should hold a portion of the reserves of the member institutions and whose advances should be controlled by a single board or directorate. It was felt by many that a banking organization more centralized in control and resources offered far greater possibilitics of avoiding credit collapses than our old decentralized system. Demands for banking reform were thus predicated upon a belief in the desirability of a single central bank. While it was anticipated that such a bank must establish local branches or agencies, it was not expected generally that there would be established in each of a dozen different districts a bankers' bank which should deal for the most part only with the banks of its own territory. It was not anticipated that a group of independently operating bankers' banks would be set up, with no one bank possessing domi- 
nating authority. It was not predicted that the board with general control would not be allied to any one bank in particular.

The motives influencing the legislators to this generally unforetold conclusion are now well known. Despite the admittedly great possibilitics of a central bank, there were many fears that such an institution would employ its resources with partiality. Recollections of the old prejudices against such an institution surviving from the time of Andrew Jackson made it appear the part of political wisdom to the Congressional leaders of both parties to soften the emphasis upon the idea of control by the directorate of one all-powerful institution. In the Aldrich Bill the plan which might be said to represent the Republican attempt to secure banking reform, the idea of coöperation and not of control was to be suggested by the name of the new system. It was to bear the name, not of a bank, but rather of the National Reserve Association. Furthermore, its machinery was to be such as not to exert any large measure of continuous control. By the issue of notes carrying a progressively increasing tax, it was designed primarily to offer relief in periods of emergency and threatened credit collapse.

The underlying theory of the Federal Reserve system was somewhat different. The reserve institutions were to bear the names of banks, and it was hoped that they would operate more or less continuously. But lest the objections to the idea of a central bank should prove too strong, attacks were to be parried in another way. There was to be no single, all-powerful central bank. Twelve regional banks, distinct in membership and direction, were to be set up, their several operations to be harmonized and coördinated by a single board. The Democratic plan, the Federal Reserve plan, was thus based upon the idea of 
preserving for the banks of each locality as much control over the district bankers' bank as seemed financially expedient. Such a solution was indeed typical for a party whose political traditions are founded so largely upon the doctrine of States' rights and local autonomy.

The wisdom of the regional idea was attacked strenuously by many. At the time of greatest controversy, however, the ultimate manner of the operation of the Federal Reserve system was more or less a matter of doubt. There was no experience by which to measure the importance of the numerous objections. But now, after nearly a decade of experience, the value of the regional idea can be appraised more accurately. What, then, does past operation suggest regarding the practicability of the plan? An inquiry, such as this projects, renders it desirable to recall some of the earlier points upon which the regional system was attacked. An advantage of restating these objections now is that by virtue of recent experience the haziness which beclouded the form of their original statement may be avoided, in part at least.

In the first place, it was felt that the regional plan would create too much temptation to the frequent use of the reserve bank's resources. The basic idea was to bring the bankers' bank more close to the member institutions. Direction was so planned as to subject its management to pressure and influence exerted by the member banks of the locality. Six of the nine district directors were to be chosen by the member banks. Moreover, the regional idea was asserted to be merely a substitute for the plan which contemplated only occasional or emergency relief for the member institutions. It was evident to all that many dangers must lie in the path of any system designed to exercise day-to-day control over the money market. To render any such control effective the advances of the re- 
serve banks must be large. The acceptance of the European ${ }^{x}$ rule of procedure - keeping the central bank's rate above the market - might leave the reserve banks a piece of unused and costly machinery. In view' of the concentration of reserve money and the consequently great possibilities of pyramiding credits, it was perceived that an unexampled expansion of bank advances might take place. In short, the regional plan, instead of guarding against, seemed actually to make provision for, price inflation.

It was asserted, furthermore, that the regional idea was solely a compromise, the outgrowth of the desire to avoid popular objection. Considerations of financial wisdom were held to have been subordinated to those of political expediency. Few have been the occasions when compromise has proved successful in matters financial, and it scarcely could be hoped that banking reform would constitute an exception. If our old difficulties were due primarily to decentralization, in credit control, note issues, and reserve holdings, the greatest advantage could be realized only by utilizing to the utmost the idea of centralization. The greatest degree of benefit could be obtained only by establishing a single bankers' bank dominating the member institutions of the entire country. Any other solution must perpetuate among the reserve banks the old evil formerly pertaining to the individual banks - scrambling for reserves in periods of emergency and excessive competition in the period of business activity. To be sure, attempts could be made to unify the operations of the reserve banks by granting certain powers of control to the Federal Reserve Board. But this, it was argued, would be merely a patchwork device. The regional system must limit somewhere the possibilities of centralized control

${ }^{r}$ Only in a very general sense is it correct to imply that the dominating policy of European central banks has been to keep the official rate above the market rate. There are, of course, many exceptions. 
and concerted action. Otherwise what would be its advantage over a single central bank?

Opponents of the plan argued also that it represented an attempt to isolate different territories of finance, to establish sectionalism in an impossible field. Finance, any more than trade, cannot be confined within artificial borders. The call-rate policy of the metropolitan bank may affect the Southern cotton planter in as real (though a more indirect) a manner as the credit policy of his own local bank. Even under our old faulty banking system many were the means by which bank capital could be transferred from one locality to another. The call rates of city banks must exert some influence upon the place of investment of surplus bank capital. Our various banking channels cross somewhere, even if in a haphazard manner. The rivulets of credit, sluggish though they be, carry eventually their deposits to the deeper channels. If the various districts of the country are related in fact, why not recognize this relationship in the structure of the banking system? Failure to recognize it must create only difficulty. If twelve different open markets for commercial paper exist, wherein has correction been found for the old evil - inability to mobilize efficiently a large portion of our surplus bank reserves at the point of greatest need?

These were some of the more earnestly developed attacks upon the regional plan. Let us next consider as completely as may be their respective merits. In doing this, however, an attempt must be made to avoid for the present those aspects of the problem which involve ultracomplicated features of reserve banking.

In the light of recent experience much justification is afforded the view that the regional system is peculiarly susceptible to undue credit expansion. Local pressure for enlarged credit grants is always most intense. Business 
thrives on easy money; rising prices usually create the situation of a widening margin between costs of production and sale procecls. 'Those who are injured by price inflation, those whose money incomes are incapable of quick adjustment, exert only fecble pressure upon the banking administration. Wage-carners scarcely ever emphasize this cause of their woes; they are much more prone to employ the devices of strikes and concerted action. The middle class has no influence upon the banking administration. Occasionally entrepreneurial activity is injured by the rising scale of prices, as, for instance, in the public utility and railroad fields. But the petitions of inclustrial entrepreneurs, in the same manner as those of the wage-carners, are scarcely ever addressed to the banking administration. Prayers for higher rates offer greater prospects of relief. Because of the nature of things, it is peculiarly necessary that the banking structure be such as to make easy denial of demands for excessive credits. It is necessary that banking control be lodged in the hands of those well equipped to resist the credit demands of those who are not responsible for the interests of all classes in society, and who do not have in mind merely the shorttime requirements of business.

One means of ensuring conservatism in the operations of the central bank is to emphasize the emergency character of the institution. Let the rates on the advances of the central institution be normally above the market rate. Advances from the central bank are thus rendered unprofitable on ordinary occasions. But aid, costly though it be to secure it, is available for periods of credit strain.

It has been stated previously that the regional idea is based on the theory of continuous control of the money market. It necessitates accordingly constant employment of reserve funds. This, in turn, imposes the necessity of 
keeping the rates sufficiently low to occasion demand for the funds of the reserve system. The rule of remaining out of the market except in emergencies is not so easy of acceptance under the regional system. Control by member banks is too direct. And so far as the particular facts of the reserve system are concerned, the regional idea was invoked as a substitute for a previous plan in which the emergency character of the institution was emphasized.

It may be that in the course of time a means may be developed whereby the volume of reserve advances may be stabilized in relation to the needs of trade even though the reserve banks are kept continuously in the market. In the opinion of the writer, however, the principles for regulating the volume of reserve advances have not yet been formulated with sufficient definiteness. ${ }^{x}$

The above paragraphs should not be interpreted as advocating absolute aloofness from the market except in periods of strain. Those who stress the emergency character of the reserve banks would admit the necessity of some measure of continuous functioning. But such operations need not be so extensive in volume. It was asserted, furthermore, that if the share contributions of member banks to the capital of reserve banks could be returned, there would be even less pressure to find continuous use of reserve bank funds. If the idea of emergency advances only were developed, could not the reserve institutions develop enough investment power without share capital contributions from member banks? Reserve banks would still possess the resources based upon their holdings of member banks' reserves. But further discussion of this aspect of the problem can best be postponed till a later chapter."

'See infra, Chapter XVI.

'See infra, Chapter XII. 
In reply to the second objection, that the regional plan was based upon the idea of divorcing various banking channels, it was replied that the scheme represented no more sectionalism than existed in fact. Attention was called to the great differences in banking customs and needs of the various districts of the country. It was asserted that nowhere in the world was there an illustration of a central bank successfully dominating so large and diverse a banking territory as that of continental United States. In the words of H. P. Willis: ${ }^{\mathbf{1}}$

So far as area is concerned, then, there would be room in the United States for a number of institutions corresponding to the total number of central banks throughout the European continent. The mere fact that international lines divide the Bank of France from the Bank of England or the Bank of Germany has no relationship to the economics of the situation. It is a fact that no such extent of territory as the United States is dealt with by one single central bank. The Federal reserve system, with its series of reserve-holding institutions, therefore, does in fact correspond much more nearly to European practice than would a single central institution with branches. Each Federal reserve bank includes within its district a territory which, as the nation expands and its business increases, will rank with the territory tributary to one of the European central institutions.

From the point of view of directness and efficiency in administration, justification for Mr. Willis's remarks is clear. The regional character of the system has eliminated, undoubtedly, many anticipated difficulties of direction. But has this been accomplished at the expense of destroying all possibilities of financial coöperation between the various reserve banks? Has the reserve system meant the segregation of financial territories and the consequent destruction of any effective means of establishing a countrywide market for commercial paper of various origin, in

'The Federal Reserve, p. I28. 
such a way as to enable the surplus funds of the country to be mobilized effectively? More precisely, have the reserve banks shown willingness to aid each other, by means of the rediscounting or direct purchase of each other's paper?

In developing this inter-district harmony the succession of events has favored the administration. In the early years of operation, the period when no past experience in coöperation was possessed, a time accordingly when attempts to secure mutual aid would be difficult, there was little demand for this sort of reserve activity. Due to the reduction of reserve minima under the terms of the act and to the importation of gold from abroad, reserves of all the district banks were generally high. When the need of inter-district aid did develop, the Nation was engaged in a war so enveloping as to render apparent to all the necessity of subordinating considerations purely of sectional advantage. In such a situation it was easy for the Board to insist, in the determination of the inter-district shifting of funds, upon principles which ordinarily might have created some objection. At a time when so many devices of expansion were available, concessions by one bank would not necessarily impair its own lending power. Accordingly, as a guiding principle, reserves were to be equalized between the various district banks regardless of the cause of any bank's need for aid.

The accompanying table on page Io indicates the volume of such inter-district operations during some of the years when their amount was exceedingly heavy.

Needless to remark, operations so large in volume have affected greatly the reserve positions of the district banks on numerous occasions, increasing the reserves of some and lowering those of others. Indicative of this is the accompanying table on page $\mathbf{I} \mathbf{r}^{\mathbf{x}}$

'See Report of the Federal Reserve Board for 1919, p. 8. 
Intier-District Movenent of Discounted and Purcihased Paper

\begin{tabular}{|c|c|c|c|c|c|c|}
\hline \multirow[b]{2}{*}{ BANK } & \multicolumn{2}{|c|}{ FOR THE YEAR 1918} & \multicolumn{2}{|c|}{ FOR IHE YEAR 1919} & \multicolumn{2}{|c|}{ FOR TUE YEAR 1920} \\
\hline & $\begin{array}{l}\text { EXCESS } \\
\text { MOVE- } \\
\text { MENT } \\
\text { FROM }^{2}\end{array}$ & $\begin{array}{c}\text { EXCESS } \\
\text { MOVE- } \\
\text { MENT } \\
\text { IO }\end{array}$ & $\begin{array}{l}\text { EXCESS } \\
\text { MOVE- } \\
\text { MENT } \\
\text { FROM }\end{array}$ & $\begin{array}{c}\text { EXCESS } \\
\text { MOVE- } \\
\text { MENT } \\
\text { IO }\end{array}$ & $\begin{array}{l}\text { EXCESS } \\
\text { MOVE- } \\
\text { MENT } \\
\text { FROM }\end{array}$ & $\begin{array}{c}\text { EXCFSS } \\
\text { MOVE- } \\
\text { MENT } \\
\text { TO }\end{array}$ \\
\hline \multicolumn{7}{|c|}{ IN THOUSANDS OF DOLLARS } \\
\hline Boston....... & $\$ 92,046$ & & $\$ 131,165$ & & & S 986,280 \\
\hline New York .... & 329.491 & & 996,412 & & $\$ 764,219$ & \\
\hline Philadelplia .. & & $\$ 56.562$ & 826,521 & & 191,872 & \\
\hline Cleveland .... & & 207,534 & & $\$ \quad 463,909$ & & $1,120,832$ \\
\hline Richmond .... & 68,732 & & 837.866 & & 699,675 & \\
\hline Atlanta ...... & 77,722 & & 72,625 & & 250.510 & \\
\hline Chicago..... & & 195,192 & & $1,583,864$ & & 108,054 \\
\hline St. Louis . ... & 679 & & & 181,029 & 302,249 & \\
\hline Minneapolis ... & & 82.907 & & 536,513 & 253,096 & \\
\hline Kansas City ... & & 27,564 & & 16,060 & 386,137 & \\
\hline Dallas....... & 94.135 & & 337,398 & & 292.513 & \\
\hline San Francisco. & & $93,0.56$ & & 420.612 & & 325.105 \\
\hline Total ..... & $\$ 662,805$ & $\$ 662,805$ & $\$ 3,201,987$ & $\$ 3,201,987$ & $\$ 3,140,271$ & $\$ 3,140,271$ \\
\hline
\end{tabular}

1 The following extract from the Federal Reserve Bulletin for October, 1920 (p. 1015), is explanatory of the relation of the Gold Settlement Fund to the inter-district shifting of funds:

"Originally established for the purpose of expediting the settlement of balances in gold between Federal Reserve Banks arising out of exchange and clearing operations the shifting of funds from district to district in connection with rediscount transactions between Federal Reserve Banks has become one of the principal services of the fund under present conditions, and its efficacy has been strikingly exemplified during the beavy credit strain incident to the financing of our present crops.

"When a Federal Reserve Bank, through the Federal Reserve Board, has been granted an extension of credit, and such extension has been allocated to some other Federal Reserve Bank, the extension is made effeetive through the transfer of title to gold in the gold settlement fund at Washington. The gold settlement fund . . . consists of deposits of gold which have been made by the Federal Reserve Banks and agents with the Treasury, which holds them in trust. . . The gold in this fund is seldom physically moved, though it frequently changes ownership, transfer of ownership being effected through the mechanism of the fund without the need of moving. Ownership in the fund being represented by entries in the books of the fund, an applicant Federal Reserve Bank which has been granted credit extension receives its accommodation, and the gold to which it is entitled. through a eredit entry in the gold clearing books of the Federal Reserve Board. Inasmuch as the gold settlement fund is a part of the gold reserve of each of the Federal Reserve Banks, this transfer amounts to shifting a given volume of reserve metal from a granting bank to the applicant bank. The effect is to transfer a corresponding amount of credit-granting or credit-lending power from the granting institution to the applicant. The latter is then at liberty to use it as it may see fit in extending further accommodation to the member banks within its district. The transaction has, in short, really anounted to a temporary shifting of banking funds from one district to a notler."

$2 \mathrm{By}$ this operation the bank gains in reserve money. It is given credit on the Gold Settlement Fund. See note 1 fcr description of the working of this fund.

'By this operation the bank loses in reserve money. 1t is debited on the Gold Settlement Fund. See not ${ }^{1}$ for dexcription of the working of this fund.

- Figures are compiled from the yearly Reports of the Federal Reserve Board. 
Ratio of Tutal Reserves to Combined Net Deposit and Federal Reserve Note Liabilities, December 26, 1919

\begin{tabular}{|c|c|c|}
\hline BANK & ACtUAL & $\begin{array}{l}\text { AFIER ADJUSTMENT OF RESERVES BY DEDUCTING } \\
\text { AMOUNT OF BILLS REDISCOUNTED WITI OR } \\
\text { SOLD TO OTHER FEDERAL RESERVE BANKS AND } \\
\text { ADDING AMOLN OF BILLS DISCDUNTED FOR OR } \\
\text { PURCHASED FR OM OTHER FEDERAL RESERVE } \\
\text { BANRS }\end{array}$ \\
\hline Boston........... & 44.0 & $24 \cdot 3$ \\
\hline New York.... & 40.0 & 36.2 \\
\hline Philadelphia....... & 40.8 & 32.7 \\
\hline Cleveland........ & 46.3 & 49.4 \\
\hline Richmond........ & 40.9 & 43.5 \\
\hline 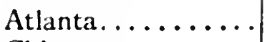 & 52.8 & 55.2 \\
\hline Chicago.......... & 50.6 & $5^{8.8}$ \\
\hline St. Louis.......... & 46.5 & 60.5 \\
\hline Minneapolis....... & 39.4 & 39.4 \\
\hline Kansas City...... & 43.1 & 41.3 \\
\hline Dallas........... & 49.4 & 77.0 \\
\hline San Francisco..... & 54.9 & 59.3 \\
\hline For all banks...... & 44.8 & 44.8 \\
\hline
\end{tabular}

The amount of inter-district lending of funds has thus been great. But to what factors shall we ascribe the willingness of the various banks to coöperate in this way? Has it been due to the unusual circumstances of the period when operations of this sort were the greatest? Has it been merely an aspect of the problems of war and post-war finance? Or has it been the desire of the lending bank to establish a basis for its own pleas for aid when it itself should become the needy institution? Answers to such queries as these should threw some light upon the probable future amount of inter-district operations.

Some explanation of the preceding problems is afforded by the following sentence from the Federal Reserve Bulletin for October I, I920: ${ }^{\mathrm{I}}$

The process of shifting bank resources through inter-reserve rediscounting was necessarily called into play and has become a regular and important feature of the working of the Federal Reserve System.

I Page rorf. 
As to how this function of the reserve has developed, it will be recalled that in the earlier years under the reserve system the effectiveness of the machinery for transferring funds from district to district was not fully tested. The release of reserves on the inauguration of the reserve system and the inflow of gold from abroad in the following years made unnecessary the use of reserve funds to any appreciable extent. But after the period of rising prices during the war and the getting more completely into the market of the Federal Reserve, inter-district aid became necessary on the part of the district subjected to unusual crop-moving or seasonal demands. Since, however, the peak of money demand is not reached simultaneously in all districts, it is possible for the Reserve Board to offset the seasonable fluctuations and changes in demand against one another. In this way the strain previously thrown upon the city banks in the financial centers by the calls from the interior becomes merely a transfer of surplus reserve funds from one district to another.

Various are the circumstances which determine the extent to which any one district bank may require such aid. Industries dependent largely upon agriculture must experience usually greater seasonal fluctuations in the demand for bank capital than those more largely manufacturing. Districts covering a territory diversified in climate and in the nature of their industries may be able more easily to finance exceptional demands in one part by reliance upon surplus funds in another without drawing heavily upon other districts. A section thus diversified is Number 12, the Pacific Coast Section, including States from the Canadian border to the boundary line of Mexico.

By relying upon the principle of reciprocity in the meeting of their mutual seasonal and emergency demands, it may be possible to avoid to some extent the objection of 
sectional financial isolation. It is true that the regional system creates some obstruction to the free flow of funds from district to district. Some friction will be encountered always in mobilizing effectively free bank funds. But this difficulty can be mitigated greatly and is perhaps justified by the administrative efficiency and political advantage of the regional plan.

One difficulty remains, however. If inter-district shifting of funds is regularly contemplated, wherein lies the advantage of the regional system in meeting objections emphasizing possibilities of sectional discrimination? Rediscounts by one reserve bank for another can be required by the Federal Reserve Board. According to the liberality with which it treats one district, and the conservatism another, the display of sectional partiality is easily possible. If exercised, its results would be identical with the more direct partiality displayed by the directorate of a single central bank.

In the opinion of the writer, however, partiality in requiring reserve banks to render inter-district aid is not nearly so probable. Under the reserve system it will be expected that the borrowing districts in normal years shall not merely clear their books in the off season, but also shall be able to render aid to other districts in the slack season. In the long run the advances to member banks in any one district must bear some relation to the resources of the reserve bank, resources which represented originally the contributions of the members. Under a single bankers' bank the determination of the legitimate amount of advances to any one locality must be based on more hypothetical grounds. Failure to map out definite and permanent districts would create much more difficulty in determining the relative merits of the demands of the various sections of the country. Under the present sys- 
tem the resources of each reserve bank are real and the advances to any one section do not depend so largely upon the rulings of a single directorate.

A query, of possibly greater im portance, relating to the political expediency of the regional plan, necessitates some concluding discussion. How effective has been the regional plan in enabling the general administrative body - the Federal Reserve Board - to confine complaints to the district in which the discontent has arisen? To what extent has the Board been able to disclaim responsibility for policies initiated by the district directorate? In what measure has each district been held responsible by the public for conditions logically the result of its own policies? Very important is the answer to this query because the system is much more likely to be modified by legislative action when complaints are directed against the central administrative body than when directed merely against one of the twelve administrative subdivisions.

It must be admitted at the outset that there has been a persistent refusal by the general public to recognize the regional character of the system. In the period of agricultural depression following the spring of 1920 , nothing was more clear than this. Newspapers and journals of the Middle West and South wrote many an editorial and published many a cartoon to establish the partiality of the Federal Reserve Board toward the metropolitan financial interests. In virtually all of these the existence of different reserve banks in the various sections of the country was ignored. "The men who grew the wheat" could not obtain credit to hold their crops for a fair price, whereas the "men who tried to corner the wheat market," it was asserted, were bountifully supplied with funds emanating from the Federal Reserve. No attention at all was ordinarily paid to the fact that the National City Bank of New York is 
served by the New York Reserve Bank; whereas the First National Bank of Waycross, Georgia, is served by the Atlanta Reserve Bank. ${ }^{\mathrm{I}}$

Indicative further of this point of view, there is even to be found an address of the former Comptroller of the Currency, and ex-officio member of the Federal Reserve Board, Mr. John Skelton IVilliams, delivered in Augusta, Georgia, July I4, I921. ${ }^{2}$ The following extract may be quoted from this address:

While small banks in the farming districts were being taxed in this manner, great banks in New York were being supplied with practically unlimited amounts of money at 5,6 , and 7 per cent. The official record will show that while the Reserve Bank collected \$2 Ioo (equal to 8 per cent on the bank's entire capital stock for 12 months) from a little bank in your adjoining State of Alabama, for the use of about \$112,000 for two weeks in crop-moving time, a year ago, a big bank in New York, whose funds were largely employed in speculative operations and deals, for the same cash consideration, or, say, \$2100, was given the use of about $\$ 800,000$ for the same time.

And in his charges of wasteful and uneconomical expenditures before the Atlanta audience the bulk of the illustrations were drawn from the experience of the New York bank. The financial layman could easily gain the impression that the Federal Reserve Board was a bank with its main office in New York City.

In view of such assertions as these by a former member of the general administrative body, it is not at all surprising that a large portion of the lay public has been induced easily to convict the Board of sectional partiality, even

'It is indisputable that reserve funds found their way in large amounts in the post-war period to the speculative markets. But in the opinion of the writer this was an inevitable, though unintended result of the "easy-money policy" of the funancial administration in the war and post-war periocl. This aspect of the problem will be discussed in later chapters.

'This address is published in the Commercial and Financial Chronicle, July 23, 1921, pp. $354^{-58}$. 
though its regulations have been general and scarcely ever possessed merely a sectional application.

Despite repeated assertions regarding the limitation of its own powers to points of general policy, the Federal Reserve Board has found it exceedingly difficult to define the sphere of regional responsibility. Attempts to establish the accountability of the district directorate for its own specific acts have always occasioned severely adverse criticism. Indeed one of the legislators, possibly more responsible for the final form of the Reserve Act than any other one man, Senator Owen, complained on one occasion most bitterly ${ }^{\prime}$ that the Board's policy meant the abdication of its powers. Thus:

The Federal Reserve Board was created to control, regulate, and stabilize credit in the interest of all the people. . . [It] is the most gigantic financial power in all the world. . . . Instead of using this great power as the Federal Reserve Act intended that it should be used, the Board abdicated. Instead of using this power in the interests of all the people, the bankers included, it delegated this power to the bankers. ${ }^{2}$

As long as the act entrusts to the Board such general powers as supervision of rediscount rates; since decisions in such matters must always affect some districts more vitally than others, it will prove most difficult to place upon the shoulders of the district directorate any large measure of responsibility for what is believed to be the industrial and business results of its general credit policy. No matter how refined the game of "passing the buck," success stands to be won by the body most frequently in contact with the public. The local banker, in denying credit accommodations lays responsibility upon the district directorate; the district board calls attention to the warnings of the Board against the granting of "unessen-

'Cf. Commercial and Financial Chronicle, July 30, I921, p. 475.

${ }^{2}$ Six of the nine district directors are selected by the member banks. 
tial credits." The Board, however, can find no body higher up, unless it be the legislators responsible for the terms of the statute.

Nevertheless, the writer believes that the regional plan has many merits of political expediency. The reserve system is new, and much educational work still remains to be done in acquainting the public with the nature of its organization and operations. Because of the exceptionally abnormal period during which it has lived, it has been impossible for the Board to develop a permanent principle regulating reserve bank advances.

Furthermore, the responsibility of the district directorate has undoubtedly rendered it easier on many occasions for the Board to resist the directly expressed demands of certain special interests for credit advances. It has enabled the Board to insist that it itself was not a bank and had no money to loan. Thus Governor Harding was enabled to write Senator Smoot of Utah in the summer of I9I I : ${ }^{x}$

In view of the fact that the twelve Federal Reserve Banks are independent bodies corporate and are controlled and directed each by its own board of directors, subject only to the general supervision of the Federal Reserve Board, whose authority with respect to discount is confined principally to defining eligible paper in accordance with the terms of section 13 of the Federal Reserve Act, it seems to me that the statement which many, both in Congress and on the outside, urge be issued by the Federal Reserve Board, stating that the Federal Reserve Banks will adopt certain policies in connection with the rediscounting of agricultural paper, would have to be made by the Federal Reserve Banks themselves. The Federal Reserve Board has no power to interfere with the discretion given or the responsibility imposed by law upon the directors of a Federal Reserve Bank with respect to passing upon the merits of eligible paper offered for discount.

'This letter, written July I I, I92 I, is published in complete form, in the Federal Reserve Bulletin, August, 1921, pp. 895-99. 
Congress did not establish a central bank in this country. It established twelve banks under the general supervision of the Federal Reserve Board, which does nol exercise banking functions. ${ }^{\text {I }}$ These functions are exercised exclusively by the Federal Reserve Banks.

We are now in a position to derive a general conclusion regarding the merits of the regional system. Politically it appears to the writer to have been a clever device. It has served to some extent in the past, and undoubtedly should serve to a greater extent in the future, to localize sectional complaints, and thus to ward off attacks which otherwise would be launched upon the reserve system as a whole. In an administrative way it has rendered possible an enormous increase in business with a minimum of friction. Had the plan of I9I 3 been that of a single central bank, it is by no means impossible that by administrative development it would have been organized finally upon lines somewhat similar to those of the reserve system of to-day. Many duties can best be performed locally; district branches must be provided under any central banking system to assist in the work of check clearances, examinations of condition of member banks, analysis of the quality of paper of local origin offered for rediscount. Should such a system get into the market continuously, the work of these branches might not prove far different from that of the regional banks of to-day.

The most vulnerable point of the regional system, in the mind of the writer, is the closeness of contact between the district directorates and the member banks. As inclicated previously, this feature was dependent upon the desire to establish a group of bankers' banks which should exercise some measure of continuous control over the money market. The advantages of a smoothly working

'The italics are the writer's. 
system of this sort are evident to all. But unless there are developed principles of credit control, more sound economically than those enunciated in the past, the plan may prove to have been too ambitious. It might have been better to have proceeded upon the more modest lines of devising merely an emergency machine. But, as it is, the problem of the future is to develop sound rules for the regulation of the credit advances of a set of banks permanently in the market. 


\section{CHAPTER II}

\section{CHECK COLLECTIONS AND CLEARANCES UNDER THE FEDERAL RESERVE}

THE early treatment of the subject of check collections and clearances may evoke some surprise in the mind of the reader. In criticisms of the old banking system following the crisis of 1907 , principal attention was not devoted to the country's clearance difficulties, and in most current discussions major emphasis has been placed upon the new system's discount functions. Nevertheless, the writer feels that the development of the Federal Reserve's par clearance system should be given a position of prominence.

Prior to 1914 clearing houses and clearing systems represented the most important institutions of coöperation developed through the initiative of the banks themselves. But the work of these institutions was not the most efficiently coördinated and systematized. In particular, the various sections of the country were not served by any single set of clearing institutions. What has been done under the Federal Reserve is to establish common centers for each of the districts under conditions whereby the work of each will be closely related. If we hold to the view that the reserve system was established primarily to secure more effective coöperation in banking, the importance of the clearing functions of the new banks is clear.

Check clearances, moreover, indicate more largely than any other single function the need of the continuous operation of the reserve banks. The volume of rediscounting must alter greatly with changing business conditions; it 
may be that on certain occasions there will be very little demand for the reserve system's funds. In the early years of operation, for instance, little success was achieved in the desire to get the reserve banks actively in the money market through their cliscount functions. Then, especially, was it highly important that a service be developed for which member banks would find a constant need.

In no matter of government and administration, furthermore, has more tact and diplomacy been required than in the efforts to extend the scope of the reserve clearing system. In the early legislative history of the statute no provisions were more vehemently attacked than those providing for country-wide par collections. After the date of inauguration each step in the development of the clearing system has been carefully observed and analyzed by the great number of country banks. In view of the impossibility of building an imposing reserve edifice upon the insufficient foundations of limited membership, this attitude of the country banks often compelled the modifications of plans which the requirements of efficiency would otherwise have dictated.

Difficulties in check collections existing prior to 1914 are generally understood. In the first place, the indirect routing of distantly drawn checks created much delay in securing the return of checks to the drawee bank. As a second aspect of this difficulty reserves were built up in an exceedingly unscientific manner and consisted frequently to a large degree of checks in the mails. In the third place, check collections were rendered more expensive because the local clearing system usually comprised a portion only of the banks in the locality. It is a well-known principle of check clearances that the possibilities of off set ting clearing debits by clearing credits are limited when the system does not embrace a large portion of the banks which mutually 
receive and collect each other's checks. One bank may receive in a day about the same volume of checks drawn aggainst other banks as the other banks receive against it. But there is no guarantee that in a collection system of limited scope any one bank's credits may not greatly exceed its debits and vice versa.

But to consider these difficulties more in detail, let us first turn our attention to the matter of the indirect routing of checks. The purpose of this prevailing custom was to enable some bank to avoid the deduction of exchange charges imposed by the drawee institution. Bank $A$, in one district, receives checks drawn against Bank $B$ in another district. If $\mathrm{A}$ sends these checks directly to $\mathrm{B}, \mathrm{B}$ would customarily remit something less than their full face value. Justification for this deduction was in part the clerical labor and other expense necessitated in the making of remittance. Bank $\mathrm{B}$ must remit by dispatehing currency by registered mail or express, or by drawing against a foreign balance previously established for this particular purpose. The building-up of these foreign accounts, be it by the purchase of exchange, the shipping of currency, or the discounting of its own note, was costly. Bank $\mathrm{A}$ in turn might attempt to recoup itself for this exchange deduction by imposing an exchange charge upon the individual who deposits the check. In many situations, however, banking customs were so firmly established and banking competition so keen as to render impracticable such a practice in the case of regular clients. All the greater, consequently, was the necessity of avoiding if possible the loss through the deduction of exchange in Bank B's remittance.

One of the means of escaping such a loss would be for Bank A to establish par relations with banks in foreign territory. Two banks located in different parts of the country could agree to collect for each other checks drawn 
against banks in a certain prescribed territory. ${ }^{\mathbf{I}}$ Thus Bank A gives full par credit to Bank $\mathrm{C}$ for the deposit of checks drawn against banks in the neighborhood of Bank A. Bank $C$ does the same for Bank A. If Bank B is located in the district of Bank $C$, Bank $A$ is able to collect through $\mathrm{C}$ without loss checks drawn against $\mathrm{B}$. But in order to induce some outside bank to collect at par and thereby absorb the exchange charge, it was of ten necessary for one of the banks to maintain a deposit balance in the other. Thus:

The First and Old Detroit National Bank carries deposits accounts in banks scattered over the country for the purpose of getting checks collected at par. In fact such checks are not collected at par, because the bank loses the use of its funds on deposit. The interest on such funds is the price paid for the "par" collections."

But the point most to be emphasized here is that the existence of such par points served to impede the direct return of checks. Instead of being sent directly to the drawee bank for remittance, they would be dispatched to the par or free city, where perhaps they would be again indirectly routed to the drawee bank. Bank $A$, for instance, dispatches checks drawn against Bank $B$ not directly to $\mathrm{B}$, but to its collection correspondent, Bank $\mathrm{C}$.

This devious routing increased the number of banks through which the "homing" check passed and padded the expenses of collection. But possibly more important than this increased expense was the manner in which such distantly drawn checks were customarily handled in the creation of legal reserves. By the practice previously per-

'A good account of such arrangements is contained in an address by lliliam J. Gray, at Portland, Michigan, August, 1916. 'This address was published in the Michigan Inestor and quoted by the Conmercial and Financial Chronicle, August 19, 1916, pp. 636-37.

2Ibid. 
mitted by the Comptroller of the Currency, the country bank remits a cash letter to the bank which acts as its collecting agent in the reserve city, "and on that day charges the amount of that cash letter to its reserve agent and considers it a cash balance and part of its reserve." $x$ Needless to remark, the reserve agent may find it impossible to collect from the drawee bank for some days. It, in turn, may forward the check indirectly through one of its par correspondents and thereby create a reserve balance for itself. The same check may suffice finally to establish several fold its face value in reserve money before being charged to the account of the drawer. As a final outcome the check may retrace its path marked "no funds." At one time it was estimated that the amount of checks in the mails - the so-called "float" - amounted to three hundred millions of dollars daily. ${ }^{2}$

The desirability of correcting such evils as these would appear to have furnished sufficient warrant for the alteration of former collection methods. But certain special circumstances, possibly less fundamental in their importance, supplied in large measure the raison d'être for the new machinery. Among these was the fact that under the reserve system it became necessary for the reserve banks to assume many functions previously provided for by the city correspondents of the country banks. There is no doubt but that in the discussion over banking reform victory was won by the "interior" as against the financial interests in the metropolitan centers. In the panic of 1907, interior banks found themselves unable to secure funds by drawing upon their New York deposits. This,

\footnotetext{
'From an address by Benjamin Strong, Jr., delivered June 24, 1915, before the New York State Bankers' Association at Saratoga Springs, New York. A portion of this address is published in the Economic World, July 17,1915, pp. $74-76$.

${ }^{2}$ Cf. E. W. Kemmerer, The A B C of the Federal Reserve System, pp. 20-2I.
} 
above all, explains, in the opinion of the writer, the willingness of the country banker to lend an ear to discussions of banking reform. Academic criticisms of the old methods were not nearly so determining.

But what was the source of the 1907 difficulty in the financial centers? Was it not primarily this - bankers' balances were not invested properly, were not kept in sufficiently liquid form? Therefore must there be set up new institutions whose resources should be available for the members in time of need, institutions whose investments must be kept liquid. The reserve banks were to become the city correspondents of country banks. But if the reserve banks were to function in this manner they must give credit for checks forwarded for collection by the member institutions. Otherwise the member banks would find the new machincry costly. To the foreign deposits established for purposes of collection must be added deposits the Reserve Act required to be kept with reserve banks. To avoid such duplication of deposits and, accordingly, of expense, the reserve banks, themselves, must act as collection agents. But if the credits, the reserves, of member banks were to be real and not hypothetical, the old method of establishing reserves must be modified. The "float" feature must be abolished.

Banking reform, moreover, was not solely the result of criticism by bankers. It was to a very great degree the result of the demands of business which had been insisting for years that exchange exactions were unduly burdensome.

It has been stated previously that, in their eagerness to secure deposits of country banks, city institutions were often willing to absorb exchange charges by giving immediate and full credit for the deposit of country bank checks. Often no attempt was made to recover this loss from the public. Nevertheless, the amount of exchange 
charges paid by the public aggregated an enormous sum and there was an insistent demand that by the establishment of more efficient methods of check collections the burden borne by the public should be lightened.

These exchange exactions, moreover, were not always imposed equitably, a feature which served to increase the public discontent. In Baltimore, ${ }^{\mathrm{I}}$ for instance, there was an old rule of the Clearing House that out-of-town items would be taken at par only from depositors who had been regular customers of their banks at the time, years ago, when a new rule was adopted requiring such charges of new depositors. But if an old customer should change his account to another bank, he was considered as a "new account" and lost his privilege of depositing at par. Change from one bank to another was not free. New corporations and new enterprises explained their hesitancy to establish themselves in this city on the ground that they would be handicapped in their competition with the older firms. In one case the par-deposit privilege was lost merely by a change in the firm name. The new name compelled the application of the rule applying to new businesses. Amid such conditions as these there was a widespread demand that the reserve system provide for the limitation of such exchange exactions.

In the earlier legislative stages of the Federal Reserve Act provisions were inserted the intent of which was to eliminate these charges entirely. But the bill thus framed met speedy and vigorous objection on the part of a great majority of the exchange-charging banks. Many country banks asserted that the elimination of such charges would impair very seriously their profits. Nor would they accept the argument that in the course of time their interest

${ }^{x}$ Cf. weekly circular of Nelson, Cook \& Co., of Baltimore, issued August 5 , 1916. References to this circular are to be found in the Commercial and Financial Chronicle, August 12, 1916, p. 534. 
charges automatically would be increased to compensate for such loss; that since the competition between banks must determine the rates on bank loans, equal treatment to all could mean no discrimination against any one in particular. Country banks maintained that in many situations local competition was not operative in large degree; that custom and law were frequently so determinative as to prevent the shifting of such loss to the borrowing public. All banking communities, furthermore, display some rivalry one with another. The time has passed when banking custom ean decree uniformly that a local inclustry shall depend exclusively upon the local bank. Elimination of such charges would handicap most those institutions which in the past had depended upon exchange for a considerable portion of their profits. By the proposed new law the city institutions would often gain more than they would lose. In the past many of them had been willing to absorb such charges for the privileges of receiving the accounts of the country banks. It was of ten forgotten that under the Reserve Act these city institutions stood to lose a large portion of bankers' deposits through the transfer of reserves to the reserve banks. It was accordingly asserted that the elimination of exchange charges must affect most injuriously those banking institutions which previously had experienced the greatest difficulties in realizing reasonable profits.

The collective legislative influence of the country bankers was enormous. Not merely did their number enable them to bring pressure to bear upon very many legislators, but it was peculiarly essential that the provisions of the act be not such as to cause the refusal of any large number of eligible banking institutions to join the system. It is not difficult, then, to account for the alteration in the terms of the bill according to which it was 
expressly stipulated that nothing in the act should be so construed as to prohibit a member bank from charging its actual expenses incurred in collecting and remitting funds, or for exchange sold its patrons.

We may now summarize the various provisions of the act as finally enacted dealing with check collections and clearances. First, there was the provision of section 16 that

Every Federal reserve bank shall receive on deposit at par from member banks or from Federal reserve banks checks and drafts drawn upon any of its depositors, and when remitted by a Federal reserve bank, checks and drafts drawn by any depositor in any other Federal reserve bank or member bank upon funds to the credit of said depositor in said reserve bank or member bank.

This provision is made subject to the exception noted above. Since a Federal Reserve Bank is thus required to give credit to other banks, economy and efficiency would demand that it clear the checks thus received, in order to employ the most economical method of determining the net credit or debit balance due from or to any bank. Accordingly there was enacted the further provision in the same section that the Federal Reserve Board

may also require each such [reserve] bank to exercise the functions of a clearing house for its member banks.

This last-quoted provision would concern intra-district clearings. But the receipt by one reserve bank of checks drawn against member banks in other districts would create debits and credits among the various reserve banks. Bank A of district one receives credit for a check drawn against Bank $B$ of district two. The reserve bank of district one recoups itself by charging to the reserve bank of district two. In similar fashion the reserve bank of district

'A similar provision was contained in the first paragraph of section I3. 
three receives items collectible in district two and vice versa. Accordingly another sentence of section 16 gives the Federal Reserve Board discretionary power to

exercise the functions of a clearing house for such Federal reserve banks.

This, as noted in Chapter I, made necessary the later establishment of the Gold Settlement Fund at Washington.

From the wording of the act, it would appear as if the exchange-charging banks had won a complete victory. The law provided that the reserve banks "shall" receive at par checks drawn on member banks. It furthermore reserved expressly the right to the drawee bank to deduct reasonable exchange for expenses incurred in collecting and remitting funds. Must not the reserve banks be obliged, therefore, to absorb the costs of collecting checks?

Means of escaping the absorption of such charges would seem to lie, therefore, in the following lines of action: First, the "shall" in the clause of section I 6 above referred to might be construed as permissive and not mandatory." Such a construction, however, was unlikely, as it would involve a perversion of the meaning usually understood to pertain to the word "shall." Second, the reserve bank might agree to bear the expense of remittance of funds from member to reserve banks, . and thus, by eliminating this item of expense, destroy, partially at least, the right of the drawee bank to charge exchange. If necessary checks could be presented at the counter and their full face value demanded. In the third place, the permissive "may" of the last paragraph of section $\mathrm{I} 6$, relating to the clearing functions of reserve banks, might be so construed as to deny membership in the clearing system to those member banks which insisted on deducting exchange. In

'Some slight confirmation of this view is afforied by the fact that the similar provision of section 13 contained the permissive " nay." 
other words, the permissive "may" might enable reserve banks to refuse to clear for banks which would not agree to whatever conditions should be imposed upon clearing members. One of these conditions might be the agreement of a member bank to remit at par. 'The final outcome of the clearance problem must depend much upon future statutory interpretation and administrative procedure.

Because the work of the reserve banks must be built up anew on bed-rock foundations, it was not to be expected that the reserve banks, immediately in I9I4, should begin the exercise of all the functions contemplated for ultimate development. Neither was it expected that the various reserve banks should all operate at the outset in precisely the same manner. Beginnings were slow and varied much between the various district banks. In the early days the New York Reserve Bank, for instance, would receive checks drawn only on rescrve banks and those drawn by a member bank on another member institution in the cities of New York, Albany, and Brooklyn. ${ }^{x}$ On December I, I9I4, the Federal Reserve Board granted the reserve bank of Kansas City power to clear checks presented by member banks drawn on member banks. ${ }^{2}$ St. Louis was also among the first to provide such service and on the 4 th of March, I9I5, it was announced by the Board that the Chicago Federal Reserve Bank had been clearing checks between the member banks of the seven Reserve and Central Reserve cities of the district. ${ }^{3}$ But on the same date it was announced that only three reserve banks, those of Kansas City, St. Louis, and Chicago, had taken advantage of the clearance privileges conferred by the act.

${ }^{I}$ Cf. letter by Governor Strong, of the New York Reserve Bank, in the Commercial and Financial Chronicle, December 5, 1914, p. 1636.

${ }^{2} \mathrm{Cf}$. Commercial and Financial Chronicle, December 5, I9I4, p. I635.

${ }_{3}$ Cf. ioid., March 13, 1915, p. 867. 
Aside from the initial pressure of new work and duties there were additional reasons for delay. Inter-district clearings awaited the development of the Gold Settlement Fund, an undertaking not successfully completed until June, I9I 5. Intra-district clearings uncovered some legal objections,

it being argued that there is no power to compel a member bank not located in a Federal Reserve city to pay or have charged to its account at the Federal Reserve Bank of its district a check which it had not seen and approved prior to the times of presentation at its own counter. ${ }^{2}$

There was also a natural hesitancy to establish a clearing system, which, on the one hand, might admit the right of the drawee bank to charge exchange, or, on the other hand, to create early opposition to the system by definitely climinating such charges. Furthermore, because final transfer of reserves to reserve banks was not to be completed for three years, financial considerations created some solid basis for opposition to the immediate introduction of a complete clearance system which might necessitate the maintenance of balances with reserve banks. During the period in which reserves could be kept partially with city institutions, it might be a hardship to compel city banks to give up this clearance work to the reserve or to compel country banks to transfer balances to the reserve institutions for clearing work. Balances with the reserve banks would draw no interest. For these various reasons the Reserve Board began to work first on the establishment of a voluntary-reciprocal plan of clearances. It was believed that sufficient success might be achieved with such a system to render unnecessary measures ultracompulsory in nature.

${ }^{2}$ Cf. Report of the Federal Reserve Board for the year 1915, p. 14.

IIbid., p. I5. 
In the spring of 19I5 the Federal Reserve Board began to send to the various reserve banks descriptive circulars of the new voluntary-reciprocal plan. ${ }^{x}$ According to this plan membership was to be purely voluntary. Checks would not be cleared drawn upon banks which would not agree to remit at par. But, on the other hand, banks not agreeing to remit the full face value of checks drawn against them could not avail themselves of the facilities of the reserve system in collecting checks drawn upon other banks. Details of operation would differ in the various districts. In the Chicago district, ${ }^{2}$ the costs of operating the system were to be borne by the reserve bank and each bank must maintain sufficient funds on deposit with the reserve bank to permit the immediate charge of debit balances. The amount of such balances would be determined by experience gained as the system continued its operation. But regardless of the details, the clearing system in each district was to be open to every bank which would agree to permit the deduction at par of its own debit items. The motives for joining the system would be: first, the economies realizable in the collection of checks drawn against other banks; second, increased acceptability of the member's own checks.

In the opinion of the great majority of the banks, however, either the time for entrance was inopportune, or the obligations greatly outweighed the privileges. By January, 1916 , it was stated ${ }^{3}$ that only about twenty-six hundred out of a total number of eight thousand member institutions had subscribed to the provisions necessary for admittance. Accordingly, the Board felt that more compulsory measures were necessary. As a consequence of this belief there was devised a new system which began

\footnotetext{
${ }^{2}$ Cf. Bulletin, May I, I9I5, pp. 6-7.

${ }^{2}$ Cf. ibid., pp. 7-9.

3 Cf. Commercial and Financial Chronicle, January 1, 1916, p. 15.
} 
operation on July 15, 1916. This plan provided the nucleus for the development of the present clearance system.

By the terms of this new plan, member banks, regardless of their own volition, were to be required to pay without deduction checks drawn upon themselves and presented at their own counters. Remittance by the reserve banks through the mail was to be construed as presentation at their own counters. Settlement could be made by acceptable checks on other banks or by the shipment of lawful money or Federal Reserve notes ${ }^{\mathbf{I}}$ at the expense of the reserve bank. It would not be necessary, therefore, for banks to maintain balances at reserve hanks for clearing purposes. For its services as a collection agent the reserve bank could collect a small service charge of, say, one and a half to two cents an item from the bank for whom collections were made. In the course of time, however, such charges were eliminated.

The only compulsory feature of the new plan was that requiring payment at par from drawee member banks. Member banks were free to keep clearing balances elsewhere and to clear through private agencies if they so desired. But it was not believed that many member banks would find it to their advantage to clear elsewhere than through the reserve. If they must remit at par to the reserve banks, why not gain the advantages of collection of credit items at par? By construing the sending of checks through the mails as presentment at the counter, it was believed that legal objection could not be made to the denial of the right of a bank to deduct exchange.

Under the new system checks would also be received drawn upon such non-member institutions as coulel be collected at par. Desire to avail of the economies in the collection of credit items and to increase the circulatory

'See Bulletin, June I, 1916, pp. 262-6q. 
power of their own checks might be appealing motives influencing non-member institutions to remit at par. To make the law more clear regarding the status of nonmember banks, an amendment was secured to the Federal Reserve Act on September 7, 1916, expressly permitting reserve banks to receive deposits of all checks and drafts payable upon presentation.

This amendment, however, contained no mandatory provision regarding the remittances of State banks. Refusal of any large number of such banks to become clearing members must weaken the system seriously. The services rendered by the reserve banks must depend upon the volume of checks collectible for each clearing member. Consequently, some of the reserve banks began to search for various means of compelling membership. The measures adopted were often expensive, but were undertaken, nevertheless, on the theory that if, by presentation at the counter, the State banks could be forced to make par remittance, they would perceive the desirability of joining the reserve clearance system and thereby gain whatever advantages this system offered as an agency for the collection of their own credit items.

Collection at the counter necessitated local agencies to protest items not promptly paid. In case a member bank was located in the town, there would be no great difficulty in establishing such an. agency. Otherwise arrangements must be made to secure the services of some other institution. At one time a project was developed whereby postmasters might act as agents of the reserve banks in towns where no member bank was situated.' But undoubtedly because of its doubtful political expediency this project was abandoned. Often notaries and express agents would be employed. In some cases it is asserted that the reserve

'Cf. Commercial and Financial Chronicle, July 22, 1916, p. 284. 
bank or its agent would save up the checks of the State bank until they amounted to a considerable volume. Then they would be dispatched to the drawee bank by automobile or otherwise and presented in bulk.

Such arrangements were pushed zealously and possibly in some cases with excessive vigor. In an address delivered in the House, Representative Reavis complained on one occasion that in the town of Pierce, Nebraska, representatives of the reserve bank saved up checks until they amounted to $\$ 41$, ooo. ${ }^{x}$ Then they went in an automobile to this town and demanded payment in cash. Inasmuch as every bank bases its operations on an approximate daily correspondence of daily income and daily outgo, such measures must prove exceedingly embarrassing. Representative Reavis also charged that in its endeavor to force this bank to terms the reserve bank had a man on the ground endeavoring to organize a competing national bank.

These attempts at coercion inevitably occasioned the utmost of protest by the non-member State banks. Their protests were expressed in various ways. Bankers' associations were exhorted to exert pressure in their behalf, and efforts were made to secure the enactment of legislation prohibiting the coercive measures. In suits at law, moreover, the reserve banks were accused of exceeding their lawful powers.

As an outcome of such protests laws were enacted in several States unfriendly to the Board's plans. Among these States were North Carolina, Tennessee, and Mississippi. As a type of such legislation the Mississippi law is well worth summarizing. ${ }^{2}$ First, it definitely legalized what it called "the established custom" of banks of that State

${ }^{1}$ Extracts from this adkess are publithel in the Commercial and Finanial Cironicle, February 7, 1920, pp. 515-16.

'The complete text of this law may be found in the Bulletin, April, 1920, p. $3^{87}$. 
to charge a service fec commonly called exchange for collection and remittance. Second, banks were given discretionary power to deduct exchange on items presented by any bank, "post-office, express company, or any collection agency, or by any other agency whatsoever." In the third place, State officers were deprived of power to "protest for nonpayment any such 'cash item' when such nonpayment is solely on account of the failure of any of such agencies to pay such exchange." Furthermore, there should be "no right of action, either at law or in equity, against any bank in this State for refusal to pay such cash item, when such refusal is based alone on the ground of the nonpayment of such exchange."

Various suits at law were begun also to test the validity of the coercive measures. The most important of these was the American Bank and Trust Company et al. v. Federal Reserve Bank of Atlanta. On appeal this suit was brought to the Supreme Court of the United States. ${ }^{\mathbf{I}}$ In this case it was alleged that the practice of the Atlanta Reserve Bank had been to accumulate a large number of checks upon the exchange-charging banks, then present them at the counter, and demand cash in payment. It was complained that such methods were employed with malicious intent, for the purpose of injuring the business of the nonmember drawee banks. In the decision of the district court it was held that the defendant's right to cash checks in this way was absolute, and that the matter of malicious intent was irrelevant. This ruling, however, was reversed in the decision of the higher court. Consequently the case was remanded to the original court for decision upon its merits.

Because of its probable future importance, certain

r The opinion delivered by Mr. Justice Holmes is printed in the Bulletin, June, 1921, pp. 700-or. 
remarks of Mr. Justice Holmes, who delivered the opinion for the Supreme Court, are well worth quoting. 'Thus:

The defendants say that the holder of a check has a right to present it to the bank upon which it was drawn for payment over the counter, and that however many checks he may hold he has the same right as to all of them and may present them all at once, whatever his motive or intent. . . But the word "right" is one of the most deceptive of pitfalls; it is so easy" to slip from a qualified meaning in the premise to an unqualified one in the conclusion. Most rights are qualified.

And then, after a few illustrations of the necessity of guarding carefully our concept of "rights":

Banks, as we know them, could not exist if they could not rely upon averages and lend a large part of the money that they receive from their depositors on the assumption that not more than a certain fraction of it will be demanded on any one day. If without a word of falsehood, but acting from what we have called disinterested malevolence, a man by persuasion should organize and carry in to effect a run upon a bank and ruin it, we can not doubt that an action would lie.

To determine the lawful procedure for the defendants (the reserve bank)

it is not enough to refer to the general right of a holder of checks to present them, but it is necessary to consider whether the collection of checks and presenting them in a body for the purpose of breaking down the petitioner's business as now conducted is justified by the ulterior purpose in view.

The probable results of this decision were variously interpreted. Many exchange-charging banks hailed it as the legal solution of their difficulties, and predicted as the final outcome the withdrawal of many non-member banks from the par list and the final acknowledgment by the reserve institutions of the drawee bank's right to deduct exchange. In this vein writes Mr. L. R. Adams, ${ }^{1}$ in the Journal of the American Bankers' Association: ${ }^{2}$

'Mr. Adams was secretary-treasurer of the Country Bankers' Association of Georgia.

2 Issue of June, I921, pp. 776-79. 
We anticipate that the final effect of the Supreme Court's decision will be that both member and non-member banks will be given the right to charge reasonable exchange on checks cleared through the Federal reserve system or otherwise. However that may be, it appears that the country banks of Georgia . . . have laid out a road which the Supreme Court has paved with concrete principles of justice, over which the non-member banks may safely and smoothly travel, using as a vehicle the equity processes of the Federal courts, to a safe haven in which they may exercise their lawful functions without fear of "embarrassing, annoying and expensive" methods of forcing their compliance with unauthorized demands.

When the case was remanded to the lower court, however, for a decision on its merits, the opinion of the court was hostile to the plaintiffs. United States District Judge Beverly D. Evans held ${ }^{\mathbf{I}}$ that the reserve banks properly could collect all checks payable upon presentation, including checks drawn on non-member banks, and that they could not pay any exchange charges. As regards the method of collection the court stated:

(3) In the discharge of its duties with respect to the collection of checks deposited with them, and with respect to performing the functions of a clearing house, the several Federal reserve banks are empowered to adopt any reasonable measure designed to accomplish these purposes. To that end a Federal reserve bank may send checks to the drawee bank directly, for remittance through the mails, of collections without cost of exchange. If the drawee bank refuses to remit without deduction of the cost of exchange, it is in the power of the several Federal reserve banks to employ any proper instrumentality or agency to collect the checks from the drawee bank, and it may legitimately pay the necessary cost of this service.

(4) The process of the daily collection of checks, in the exercise of the clearing-house functions, is not rendered unlawful

I This opinion is printed in the April, 1922, Bulletin, p. 436 . 
because of the fact that of the checks handled two or more of them may be drawn on the same bank.

Only in one respect did this opinion grant comfort to the complaining banks. It was held that there should not be publication on the par list of the name of a non-member bank without its consent. While it might be true that the checks of a certain non-member bank could be collected at par, it might also be that this bank had not consented to the par clearance plan. But this is a matter of minor importance.

But before the opinion of Judge Evans was announced it did not appear to the writer that the enthusiastic predictions of Mr. Adams could be fulfilled. It would seem as if always the burden of proof regarding the matter of malicious intent would rest on the complainants. Furthermore, courts, very likely, will be inclined to be liberal in interpreting the collection difficulties of the reserve banks. It cannot be expected that the reserve bank shall submit to unnecessary expense in the collection of a single check. Economy will justify their collection in batches. To determine when malicious motives are present will require special evidence in every case. The expense of such litigation may operate to deter many of the small country banks from bringing suit. ${ }^{1}$ Finally, not everything in the opinion of Justice Holmes was favorable to the contention of the plaintiffs. For one matter, it was held that in a case of this sort the Fedcral and not the State courts possessed jurisdiction. If it be true that the general body of business opinion is hostile to the exchange charges, reserve banks may prefer to have such cases decided in the United States courts, which are more likely to be influenced by the general attitude of the country as a whole and not that of a single community.

r Of course attempts may be made to distribute this expense through the formation of associations of bankers. 
If this conclusion be correct, relief for the exchangecharging banks can be had only by securing changes in the Federal statute. As a matter of previous development such statutory alterations already had been vigorously attempted. At first only success was achieved. In the spring of 1917 the so-called Hardwick amendment to the Federal Reserve Act was passed in the Senate expressly legalizing the deduction by the drawee bank of a reasonable charge for the collection and remittance expenses, and in the House, on May I0, 1917, by a vote of more than two to one, conferees were directed to accept the substance of this amendment. Before the conferees came to an agreement, however, it was charged that intensive lobbying was employed in order to defeat the amendment. Regarding this Mr. Thralls states: ${ }^{\mathrm{x}}$

A nation-wide campaign had been conducted by the Credit Men's Association, the mail-order houses, manufacturers, jobbers, wholesalers, and merchants in the large centers for the defeat of the Hardwick amendment. These interests were ably assisted by the Federal Reserve Banks.

Material changes, which if literally interpreted will defeat the purpose of the amendment, were made in conference. When the bill was reported for consideration in the House, the point of order that the managers of the House had not obeyed instructions was overruled. This ruling, in the minds of many, is contrary to parliamentary precedents. The Administration pressure was turned on, and the report was accepted. It contained two modifications:

I. Providing that the charges are to be determined and regulated by the Federal Reserve Board.

2. Providing that no such charges shall be made against the Federal Reserve banks.

This last modification, when it became law, took the

ICf. Mr. Jerome Thralls, secretary of the National Bank and Clearing llouse Sections of the American Bankers' Association, in the Journal of the American Bankers' Association for July, 1917. The substance of this address is printed in the Commercial and Financial Chronicle, July 21, 1917, pp. 235-36. 
teeth out of the amendment. It completely turned the tables on the exchange-charging banks. So far as the law was altered at all, it affirmed more definitely than ever the right of the reserve banks to refuse exchange deductions by drawee banks.

Mr. 'Thralls's charge that the Hardwick amendment was unfairly defeated may be true. But aside from the means employed, the Federal Reserve Board had an exceedingly strong case. In the first place, expense of remittance to the collection agent was reduced by the agreement of the reserve bank to absorb such costs on checks cleared through it. A part of the justification for the earlier practice was thus eliminated. In the second place, the prohibited charges related only to those sought against the reserve banks and did not apply to those levied upon the public. In view of the economies of collecting through an efficient clearing system, such levies, however, should be much more reasonable than those exacted under the old banking system. Banks would no longer be obliged to maintain deposits in outside private banks in order to facilitate the collection of their own checks. If the reserve banks give credit at par, should they not be permitted to collect at par? If the reserve banks are considered as acting merely as an agent for the member banks, elimination of exchange charges could not affect them at all in the aggregate. To the extent that one bank is denied an item of income, another is saved an item of expense.

It will always be extremely difficult to ascertain the real attitude of the banks toward the Board's clearance plan. Many bankers who disliked this feature of reserve operation may have withheld vigorous objection because of their dependence upon other functions of the Federal Reserve. On the other hand, some of the larger city banks may have felt it impracticable to take a leading part in the 
agitation for the spread of the plan for fear of estranging the country banks for whom they wished to continue to serve as city agents. In point of numbers, however, it is undoubtedly true that the decision of the bankers would be decidedly unfriendly. At least, the results of most referenda indicate general hostility toward the plan. In one such referendum, conducted by Mr. Jerome Thralls, of the Clearing House and National Banks Sections of the American Bankers' Association, more than three fourths of the réplies gave a negative answer to the following question: "Is the plan of clearing and check collection now operated by the Federal Reserve banks satisfactory to you?" " On another occasion Governor Harding, of the Federal Reserve Board, admitted that probably twenty thousand out of twenty-four thousand acquiescing banks had agreed to the system unwillingly. ${ }^{2}$ Mr. Harding justified the plan on the ground that it represented solely the sincere desire to administer the law. If relief was desired, he insisted that pressure should be brought to bear upon the legislative branch of the Government and not upon the Federal Reserve Board. Stating further that the Board desired to clear up any possible vagueness as to the intent of the legislators, he even suggested the terms of a possible amendment to the law which would preserve the right of exchange deductions. ${ }^{3}$ This attitude of Mr. Harding, however, can be reconciled only with difficulty with his policy at the time of legislative consideration of the Hardwick amendment. Then he took an active, and not merely passive, position of hostility to the terms of the amendment suggested by the exchange-charging banks.

Aside, however, from the popularity of the par collection system the Board has met with remarkable success in

I See Commercial and Financial Chronicle, December 16, 1916, p. 2199.

${ }^{2}$ Cf. ibid., May 15, 1920, pp. 2034-36.

${ }^{3}$ See Commercial and Financial Chronicle, May 15, 1920, pp. 2036-37. 
its endeavors to extend the scope of the new plan. It is true that at first much difficulty was encountered. In the Federal Reserve Bulletin for February I, I9 I8, we read: ${ }^{\mathrm{I}}$

Where good progress has been made it has been almost invariably due to energetic solicitation by one or more members of the staff of the bank who have devoted their attention to the matter and have done actual work for the purpose of adding to their par list.

Nevertheless, on February I5, I922, 28,906 member and non-member institutions were on the par list and only 2,327 not on this list. On this date every bank in the Boston, New York, Philadelphia, Chicago, and San Francisco districts was a member of the clearing system. The volume of work accomplished has increased enormously. In the month January 16 to February 15,1922 , total items handled amounted to nearly eleven billions of dollars.

It has been suggested previously that the attitude of business in its desire to avoid exchange charges has been the principal support of the reserve banks in the employment of their coercive measures. Undoubtedly much of the approval of business in the early days was due to the mistaken belief that as a final outcome all exchange charges would be absolutely eliminated. As previously indicated, this is not true. There is now legal warrant for the exaction from the public of certain minimum charges. While on the whole such charges are less than in the old days, there are numerous exceptions due to the desire of many banks to make up in charges to the public what has been lost in exactions against other banks. Thus the Farmers \& Merchants National Bank of Los Angeles, California, stated in its monthly letter on September 15, 1916: ${ }^{2}$

\footnotetext{
I'age 75.

2 Extracts from this letter are printed in the Commercial and Financial Chronicle, September 23, 1916, pp. 1083-84.
} 
The banks on the Pacific Coast, for instance, have heretofore accepted Eastern drafts at par. They recoup themselves by selling exchanges against Eastern funds thus obtained. To-day, if a man walks into a Pacific Coast bank with a draft drawn by a solvent party on an Eastern bank, and wants immediate credit for the proceeds thereof, he will be compelled to pay for the use of the money until the bank cashing the draft has received its proceeds from the party upon whom it is drawn. If a merchant deposits out-of-town items and gets immediate credit for them, he will be compelled to pay the bank with whom he makes the deposit for the use of the money advanced on those items until the bank has collected them. There are a thousand and one services which banks have gratuitously performed for their customers that they will now charge for.

It will be generally agreed that such practices, if not carried to undue lengths, are as they should be. Nobody will argue that the bank should perform such services gratis. Losses encountered in one operation must be made up in others. What has been accomplished under the Federal Reserve has been to place the various services of a bank on such a basis as to increase the likelihood that each will carry a larger portion of its own cost. As previously indicated, the aggregate burden borne by the public should be considerably reduced under the new plan. No longer need so many deposits be maintained at various points throughout the country for domestic exchange purposes. No longer need checks be indirectly routed with resulting increases in clerical and postage expense. No longer is the principal clearance work of the country performed entirely by unrelated and uncoördinated clearing organizations. These economies should redound ultimately to the benefit of the public.

In order that the reserve banks should function satisfactorily as the correspondent banks of the members, it soon became necessary that they handle other items than bank checks. It would have worked a hardship to require 
member banks to maintain balances with city correspondents in addition to those with reserve banks. Accordingly in the Bulletin for September I, I9I7, ${ }^{1}$ we read that the Board requests the various reserve banks to establish collection departments for time items. At the present time the reserve system handles, in cases where satisfactory arrangements exist for collecting checks, such items as promissory notes, trade bills, trade drafts, coupons and acceptances. This extension of the reserve activities was necessary if the reserve banks were to be effective substitutes for the former reserve agents of member banks.

The growth in this collection work has necessitated a considerable enlargement of the functions of the Gold Settlement Fund. Prior to the development of the interdistrict system it was employed largely to handle transfers or drawings between reserve banks. Later it became the means by which individual banks could be benefited directly. Transfers originating with one member bank can be made in the interest of another member bank of another district. In the course of its development it became the agency by which transfers could be made on note accounts between the Federal Reserve agents and the reserve banks which they represent. Finally it became the clearance fund for the inter-district collection system. It is impossible to stress too highly its functions in enabling to run smoothly the machinery of domestic exchange.

What now shall be our conclusions regarding the merits of the par collections controversy? Shall we take the position that because of its economy and efficiency its further progress should not be impeded? Or should we conclude that, while an economy may have been wrought for the hanks as a whole, it has discriminated unfairly against the small country bank?

$\therefore$ Page 66r. 
It is clear, first of all, that the law does not prevent the country bank from levying upon the depositor of a check drawn upon a foreign bank. Sone banks, however, receive fewer checks drawn upon foreign banks than are presented to them for collection. Such charges may not be sufficient to overcome the loss due to the necessity of remitting for its own checks at par. If this be the situation, then, why not levy upon the depositor who sends a check to a distant point and thereby imposes upon the bank the burden of providing remittance?

It is obvious that much friction would be created if any such per-item expense were imposed. The necessity of such a charge would not be understood generally, and banking has so developed that the depositor has come to feel it his innate right to emit checks drawn against his account to any distant point. As a matter of business policy the country bank cannot recoup in this manner. But there still remains the possibility of recouping indirectly. Cannot the depositor be required to maintain a larger average balance? If not this, cannot it be recognized that, since former collection profits are lost, the interest charge on the original loan must be permitted to adjust itself to a higher point?

Much can be said in behalf of the method of requiring larger minimum balances. Many accounts are unprofitable; should not the country as well as the city bank endeavor to refrain from doing any portion of business at a distinct loss? The balance idea, moreover, would prove helpful in other connections, such as to render it more difficult to overdraw accounts, and to preserve for the bank funds the depositor does not require in his period of slack business. ${ }^{x}$ The only objections to such methods would

- The balance idea tends to encourage a borrower to keep, in his slack season, as large balances as possible in order that the yearly average may be high. 
be the difficulties of introducing new and unwelcome methods into a competitive situation where old customs have had time to harden.

But are these objections sufficient to warrant the restoration of the old custom of permitting deductions against the foreign bank of deposit? Should the Federal Reserve Act be so amended as to permit reasonable charges to be levied against the collection agents of the banks of deposit, the reserve banks?

Many difficulties to such a solution appear immediately. A charge against the reserve bank is an indirect charge against its member banks. ${ }^{I}$ Why should the reserve bank lessen the earnings available for the group in order that the drawee bank, which may not even be a member of the reserve system, may have its checks cleared without cost and possibly at a profit? Why should the bank, member or non-member, whose checks are distributed in largest volume in distant communities, derive extra commissions as against banks which have not created so much work and expense for outside collection agencies? Is not the reserve bank already rendering in direct as well as indirect ways, a sufficiency of free services for the non-member banks of the country? Will not the proper regulation of the reserve system prove all the more difficult if the twelve reserve banks are put under added pressure to earn at all times sufficient to offset these and similar costs?

Answers to these queries are not promising: With the change in old methods, the substitution of reserve banks for independent private banks as reserve agents, there is no longer the same justification for the imposition of large charges against the collecting bank. The solution for the country exchange-charging bank must be found in re-

The member banks are the stocklioklers of the reserve banks. Of course, the burden would be borne by the Government if the earnings were more than sufficient to meet the minimum anount permitted for stockholders. 
couping from the depositors of foreign items, by direct exchange charges imposed upon the public, by requesting offsetting balances from customers who demand the right to circulate checks outside the neighborhood of their banks, or by permitting the original discount rate to adjust itself so as to compensate for the loss.

In a rather marked manner the par collections controversy recalls the old contest for sound banking methods in the wild-cat days prior to the Civil War. Then banks customarily refused to meet willingly their obligations at par. Then they sought court action to avoid payment in full of their obligations. Then they endeavored to prevent the development of a system whereby the parity of all the elements in the currency system could be maintained. Then, however, the controversy had to do with bank notes and not with checks. But the checks of to-day occupy the place of the note issues of yesterday. Issues of banks payable to bearer are becoming relatively less important. More and more their position is being occupied by checks.

A temporary loss of profit to a portion of the banks should not be permitted to impede the development of the system of par collections. Undoubtedly some banks have a grievance. In some cases the reserve officials may have displayed an excess of zeal in their coercive measures. It may have been true that the reserve administration has not always been absolutely sincere in its defense of its own course of action. In many instances its interpretation of the law was not the only reasonable one; in other instances reserve officials advertised their own indifference to the terms of the law and insisted their function was solely to administer the statute as bequeathed to them by lawmakers, while at the same time they were exerting every endeavor to prevent a legislative change. Nevertheless, the writer believes that in the par collections controversy 
the Board has displayed rare good tact in coördinating concession and firmness; that, in so far as it has possessed discretionary power, it has employed it solely for the purpose of correcting former abuses in our methods of domestic exchange. 


\section{CHAPTER III}

\section{STATE BANK MEMBERSHIP IN THE FEDERAL RESERVE}

At the time of the framing of the Federal Reserve Act few problems presented more difficulties than those relating to the requirements for admission into the new system. A priori the weight of advantage seemed to lie on the side of a large membership. Not only would a small membership mean that the resources of the reserve banks would be small, but also that a large number of banks, by remaining outside the system, would not be affected directly by the policies of the reserve administration. In its open market, or purchase operations, a reserve system of limited membership would not have the funds to exercise any large measure of control over the money market by competing with private institutions. In its rediscount operations few banks would be dependent upon the reserve and, accordingly, capable of being affected by the rate policy of the Federal Reserve Board.

On the other hand, however, it was generally agreed that it would be a mistake, perhaps irretrievable, to make in the beginning too many concessions in order to secure the entrance of a large number of banks. The assets of the reserve banks would consist largely of paper endorsed by member banks. Should this paper prove to be of inferior quality, the resources of the reserve system must be impaired. The character of the reserve management, furthermore, must depend largely upon the member institutions. Out of the nine district directors six were to be 
chosen by the member banks. The importance of an able membership in the district directorates was clear to all. It could not be expected that the Federal Reserve Board could concern itself greatly with the detailed application of its policies to individual cases. Such duties must devolve largely upon the district directorates. Too great liberality as regards membership might also produce unfortunate results outside the system. In the attempt to maintain a place for State non-member banks, State legislatures might lessen the strictness of banking laws, and thus create an unhealthy situation in which the State and the Nation would be obliged to compete one with another for more lax, rather than for more sound, conditions of bank control. Subsequent history furnishes some confirmation as to the correctness of this fear. From the Report of the Federal Reserve Board for the year $1915^{\mathrm{x}}$ we read that some States had lowered reserve requirements materially since the adoption of the Federal Reserve in order to enable non-member institutions to compete more effectively with the members.

It was understood also that early mistakes in the direction of excessive conservatism could be corrected more easily than those of excessive liberality. It is easier to grant concessions than to employ new measures of control. Since, in all probability, the reserve framework must be altered after some years of experience, it appeared preferable to build a small superstructure on a sound foundation rather than a lofty though shaky banking house upon imperfect supports.

Too great strictness in the beginning, however, might defeat the purpose of the lawmakers. If the reserve institutions should not display at an early date the strength which comes from a large membership, popular faith, and

- Page 13. 
accordingly popular support for the new banking system might disappear. It is therefore easy to understand the difficulties of applying the preceding general observations to the specific facts of initial organization.

Over a portion of the banks of the country, the national banks, the Federal lawmakers possessed mandatory power. The only alternative to membership for these institutions would be the surrender of their national charters. Since, furthermore, it was expected that most of these banks would discern the helpful possibilities of the system, the strict provisions were inserted in the law that any national bank failing to signify its acceptance of the terms of the act within sixty days after proper notification to subscribe to the stock of its district reserve bank must cease to act as a reserve agent. If within one year after the passage of the act it failed to comply with the provisions of the act, it must forfeit its Federal charter. During the days of organization, many insinuations were current regarding the refusal of some of the country's most powerful national banking institutions to accept these terms. But it finally appeared that in many cases the motive for these veiled threats represented pressure to secure more favorable terms in the act or the endeavor of some of the banks which favored the bill to get the public in the correct psychological attitude for sanctioning the plan. It may well be that after the experience with the Aldrich plan, a scheme interpreted primarily as a measure of public control or public coercion would enlist popular support more easily.

Over the State banks, however, direct power of control was lacking. To secure their admission permissive and not mandatory provisions were inserted in the act. The more important conditions of membership for these banks were the following: ${ }^{1}$

see section 9 of the original act. 
(a) First, they must comply with the requirements relating to capital and reserves imposed by law upon national banks. Laws relating to national banks prohibiting the purchase of or loans upon their capital stock, the withdrawal of capital, or its dissipation through payment of unearned dividends, must also apply to State member banks. Their capital, furthermore, must be such as to entitle them to become national banking associations according to the population of the place in which they were situated.

(b) Secondly, they must submit to examinations and regulations prescribed by the Federal Reserve Board, and must make certain reports of dividends to the Comptroller of the Currency. In the event of failure to comply with the terms of the act or with the regulations of the Reserve Board, they could be required to surrender their stock in the reserve bank.

(c) In the third place, the banks must conform to the provisions of law imposed on national banks "respecting the limitation of liability which may be incurred by any person, firm, or corporation to such banks."

These were the pertinent provisions of the law. What has been their effect upon the entrance of State banks. Historically, State admissions may be classified as falling into two periods: first, the period succeeding organization to June 2I, I9I 7 ; second, that which followed the summer of 1917. Let us first consider the State admissions in the early period.

On June 27,1914 , it was announced that only fifty State banks had made application for membership." In the Report of the Federal Reserve Board for the year I9I we read: ${ }^{2}$

- See news item in the Commercial and Financial Chronicle, July 4, 1914, p. 16. The Federal Reserve Bulletin was not published until May I, 1915.

- Page 20. 
Since the passage of the Federal reserve act, there have been converted into National banks 93 State banks and trust companies, with a capital and surplus of $\$ 9,151,306$. There have been admitted to the system as members thereof 9 State banks and 4 trust companies, the aggregate capital and surplus of the I 3 institutions being $\$ 17,884,000$. Those State institutions which have already been admitted to the system have entered upon the understanding that they are to accept any regulations the Board may make regarding the conduct of member banks. There are pending at the present time $5 \mathrm{I}$ State banks and trust companies. These applicants have preferred to await the issuance of regulations governing the admission of State banks.

Three years later, June 2I, I9I7, 53 State banks and trust companies with aggregate capital and surplus of $\$ 78,49$ I, I65 and resources of $\$ 825$,000,000 were members. ${ }^{\text {I }}$ In view of the infinitely larger number and resources of the non-member institutions, it appears in this first period that the conditions of membership were not appealing to the great body of State institutions.

To what facts shall we attribute this unwillingness to join. Would it not appear that the statutory provisions regarding eligibility were extremely liberal? Were not the general terms of the act such as to render attractive membership for the typical country institutions? For one matter, small institutions could not object seriously to the method of selecting district directors. The method adopted was specially devised to ensure representation for the smaller banks. Legal reserve requirements, furthermore, were reduced by the act for all member institutions. ${ }^{2}$ The statute also contained no prohibitory measure regarding loans on real estate. The regulations of the Board regarding real estate loans were liberal, merely requiring that they be not carried in such liberal amounts as to

× Cf. Report of the Federal Reserve Board for the year 1917, p. I4.

2 If State laws should impose higher requirements, these would govern banks chartered by the State. 
impair the general liquidity of the bank's assets. In view of the great reliance of many state banks upon real estate loans, the generosity of these provisions was of greatimportance.

First among the reasons explanatory of the refusal of the great number of State banks to pay the price required to share in the benefits of the organization was the doubtful legal position of the applying bank. Regarding this matter the following news item published in the Commercial and Financial Chronicle for July 4, 1914, is pertinent: ${ }^{\mathrm{x}}$

Advices from the Organization Committee state that there are only twenty States in which the Treasury Department officials are sure that it is possible for State banking institutions to become members of the new Federal reserve system without some modification of the laws. These States are Vermont, New York, New Jersey, Delaware, Maryland, Virginia, West Virginia, Kentucky, Tennessee, Ohio, Indiana, Illinois, South Carolina, Alabama, Mississippi, Arkansas, Texas, Arizona, California, and Oregon. Two of these States - Kentucky and South Carolina - passed enabling acts since the passage of the Federal Reserve Act which make it possible for the State banks and trust companies to enter the Federal reserve bank system. In New Mexico and Montana it is possible for trust companies, but not for State banks, to become member banks of Federal reserve banks. The information of the Reserve Bank Organization Committee is based largely, it is said, on letters written by State officials in reply to inquiries concerning their State laws and the necessity for amendment of their statutes, so that their financial institutions may participate in the new system. Without exception, it is added, the State officials gave assurance that steps would be taken to make changes in State laws which will enable State banks to join the Federal reserve banks, if they so desire. However, in many States the legislatures do not convene until I9I5.

Gradually, however, the necessary legislation was enacted in most States and difficulty on this score largely

' Page 16. 
removed. But the delay thus enforced may have caused some State banks, whose enthusiasm was aroused in the beginning, to postpone application at a time when interest in banking reform was the most intense. With each day of delay the general attitude became more and more one of indifference. The money market was easy in the first few years succeeding I9I4 and the need did not appear for any great reliance upon the Federal Reserve. In the interval during which the permissive legislation was being framed, State bankers had ample opportunity to study the terms of the statute and analyze its apparent defects. Some of the resulting objections were sound and some were unsound. But attitude toward membership was primarily a matter of the bankers' beliefs and only secondarily a matter of the financial soundness of their views.

Among the most emphasized of difficulties was the fear that membership would subject State banks to many prohibitions applying to national banks even though these prohibitions were not contained in the Federal Reserve Act. For instance, it was asserted frequently that membership would subject the shareholders to double liability in the event of insolvency, even though the law in the State of incorporation did not impose such requirements. This fear, however, was soon dispelled by the publication of an Opinion of Counsel in the September I, 1915, issue of the Federal Reserve Bulletin, ${ }^{1}$ in which it was held that this provision of national banking law was not applicable to State banks. The only double liability resulting from membership in the Federal Reserve Act was that pertaining to the stock subscriptions in the reserve banks. Liability of shareholders on this account would be small. Of course, State member banks would be subject to the regulations of the Reserve Board. But these regulations must

- Page 273. 
be based upon, rather than in conflict with, statutory lau: But aside from restrictions and limitations of powers, what about the advantages of membership? Mould the rediscounting privilege in particular be of any great benefit to the great number of State banks? More specifically would State banks possess much of the paper eligible for rediscount? In the days of organization there was current a general belief that the Board would require financial statements of the maker of the paper to accompany rediscount applications. In its first regulations such conditions were imposed as a basis for ultimate procedure. But small banks ordinarily do not need to require, and often are not in a position to demand, such statements. It is not strange, therefore, that in a referendum conducted by the Bankers' Information Service of Washington ${ }^{x}$ the consensus of opinion was:

That although they will be compelled to pay a portion of their capital into the capital of the Federal Reserve System, where it will be tied up, they may receive no benefit because the class of commercial paper they handle is not eligible for discount under the regulations of the Federal Reserve Board.

Expressing the same prevalent view, also, was the following editorial extract from the Commercial and Financial Chronicle: ${ }^{2}$

Manifestly, since the regional Reserve bank is made up out of the stock contributions of all the banks large and small, nationals, proportionate to their stock and surplus, the benefits of the system should inhere to each in like manner, and the access for rediscount should be free to all. let we find that the status of the large bank and the small, or the country bank, is reversed by the provisions governing rediscount. Formerly it was the country bank that rediscounted its paper most freely, the large central institutions rediscounting very little and that against principle. Now, such are the provisions governing that

'Cf. Commercial and Financial Chronicle, March 27, 1915, p. 1047.

2 Issue of January 20, 1917, p. 197. 
kind of paper admissible, the city bank is meant to be, and can be, the easy and extensive borrower at the Federal Reserve Bank, while the country bank finds it extremely difficult to come within the provisions, owing to the nature of its local business, and is, in fact, scarcely at all a borrower from the said bank.

As a matter of subsequent history such fears do not appear to have been justified. In later chapters evidence will be presented that the reserve administration went the limit of liberality in its endeavors to make the reserve banks useful to all classes of institutions. Requirements concerning the filing of financial statements were altered early in I9I5 so as to constitute virtually no bar to the applying member bank. The testimony of reserve bank directors has been almost unanimous that where the reserve bank was permitted to coöperate, it was found the member bank's portfolio contained much paper, either directly admissible, or of such a character as to enable it easily to be made eligible. Confirmatory of such a view are the following remarks of Governor Strong, of the New York Reserve Bank, before a group of the New York State Bankers' Association: ${ }^{\text {}}$

The statement has also been made by some bankers of our district that very little, if any, of the paper held by their banks is eligible for rediscount with the Federal Reserve Bank. Those bankers who make this statement are liable to create the impression that this opinion is held generally by member banks; but an examination of statements filed with us disclosed that only about 80 banks, out of our 480 members, reported that they had very little, if any, paper eligible for rediscount. With these, we have communicated, in order to ascertain upon what theory their reports were based. By correspondence and personal interview, with many of them, we have satisfied them, as well as ourselves, that one half or more of the paper they hold is eligible for rediscount.

I A part of this address is printed in the Commercial and Financial Chronicle, June 5,1915, p. 1880 . 
Such conclusions as these represented the usual results of investigation in other districts.

In the rare cases where no eligible paper existed, the resources of the reserve bank might furnish indirect aid. The needy member bank might borrow on its note payable from another member bank which did possess eligible paper. Furthermore, eligible paper might be purchased from commercial paper houses or from other banks. Such paper, rediscounted, would increase the reserve of the borrowing institution; while, if arrangements could be made whereby the seller would obtain for the time being only a credit upon the bank's books, payment for this paper need not mean an immediate and corresponding loss in cash or reserve money.

The above arguments were addressed to the State banks however, largely from the point of view of their collective strength and not that of individual profit. From the standpoint of its own individual gain the necessity was not always clear for joining a set of rediscount institutions whose funds should be husbanded carefully for emergencies. From a selfish viewpoint many a bank might reason that the reserve system might be maintained by other institutions; that so far as it required rediscount aid, it could rely upon its old city correspondents, who in turn could secure aid from the reserve banks. With such institutions it had in the past maintained occasional rediscount relations, and it appeared easier to continue these old customs than to take the trouble of investigating rediscount regulations applicable to the new reserve banking system. Particularly likely was such a position to be taken at a time of great ease in the money market.

In other situations it was not so much a matter of inability to ascertain the advantages of membership, but rather a belief that admission would involve direct disadvantages. 
In this connection discussions of systems of check clearances assumed much importance. Would the reserve banks develop clearing departments which would remove the necessity of depending upon outside city correspondents? The law gave discretionary power to the Reserve Board to require reserve banks to act as clearing agencies, but did not make this function mandatory. If this service was not certain to be developed, membership might prove costly. In addition to deposits with reserve banks, accounts with city correspondents for clearance purposes might continue to be necessary. There was no probability that city banks would discontinue bidding for country bank deposits. As long as they paid interest on bankers' deposits it would seem preferable to maintain deposits with them than with the reserve banks which paid no interest.

But even if the reserve banks should make provision for clearances, it was not certain that the new facilities would offer any economies in making collections. What if the reserve banks should refuse to clear checks drawn on nonmember institutions? Unless checks on both classes of banks were to be cleared, members might be obliged to maintain balances with city correspondents for the collection of non-member bank items in addition to those deposited with reserve banks.

There was also uncertainty about the future rights of banks to deduct exchange on remittances for their own checks. As indicated previously, such charges constituted a large part of the profits of some of the smaller institutions and the prevailing custom was one working in favor of the country bank. In the early stages of the bill in Congress, the provision prohibiting these exchange deductions proved very shocking to these banks. Although this objectionable provision was modified later, it was doubtful 
whether the rights of country banks as determined by established custom was sufficiently safeguarded. The concessions granted to them in the final draft of the bill preserved their rights to deduct exchange only to the extent that costs were incurred in collection and remittance. It was foreseen by some that it was within the province of possibilities for the reserve collection system to develop in such a way as to eliminate all costs incurred in remittance. Would not the presentation of checks at the counter destroy ${ }^{\mathrm{I}}$ the justification for such charges? If so, would it not be better to refrain from adding to the resources and thereby to increase the prestige of the reserve system until definite guarantees were given regarding the right to continue to impose such charges?

On what terms also could State member banks withdraw from the system? Since the days of Andrew Jackson no American bank had had any experience with such a banking system. The success of the Federal Reserve was problematical. Its future relations to member banks must depend largely upon its management. It might become a helpful organization securing for our banking system a stability never before possessed. On the other hand, it might become the "monster" of the time of the Second United States Bank. If so, could an early mistake in becoming a member be corrected easily? Must withdrawal necessitate voluntary liquidation?

Particularly important were such questions to those State banks which were performing functions not legal for member national banks. If, after membership, such functions were being exercised, would inability to withdraw necessitate the abandonment of that kind of business? It is true that in its early regulations the Board endeavored to calm the fears of the banks by making such withdrawals

See supra, pp. 34-37. 
casily possible. But the Federal Reserve Board was a body, not with a permanent, but rather with a shifting personnel. In the course of time, because of a change either in viewpoint or membership, its regulations might be altered. Regulations, alone, did not seem to provide a sufficient safeguard.

Provisions regarding examinations were also distasteful to many State banks. By the terms of the statute certain powers of examination were conferred upon the Federal Reserve Board, and the Comptroller of the Currency had the right to require statements of condition and operation. These powers of examination and inquiry were to be added to those possessed by the State Banking Department and mayhap also to those of the local clearing house. An excess of examination was easily possible. Not merely might this involve much loss of time to the officers and clerical staff of the bank, but examination is always unwelcome because of the possibility of bank secrets being spread in this way. It would be much more difficult to trace the origin of such disclosures when examinations could be conducted by so many differently constituted bodies.

In order to quiet discontent on this score, the Board made every feasible concession. Particularly, since every bank was to be contingently liable for its rediscounted paper, and because neither the Board nor the district directorate could be expected to make careful investigations of the credit standing of the original borrower in all cases, it was unwilling to dispense with the investigation. But wherever possible there was to be coöperation with the State banking authorities in order that visits of examiners might fall as nearly as possible on the same days, and in order that there should be no useless duplication of work. In these ways objections were somewhat mitigated. 
It was understood generally that the prime purpose of the new banking system was not to secure profits for stockholders. Dividend provisions were written in the act merely to lessen the possibility of total loss of income on the capital subscription to the reserve bank. Nevertheless, the average banker could not refrain from taking into consideration this áspect of the question. Under the terms of the law six per cent represented the utmost dividends possible on the stock of the reserve banks. Additional earnings must go to the Government as a franchise tax, or to surplus. In the early years, even six per cent dividends seemed impossible, in view of the small volume of rediscounting and there was the fear of spreading, by virtue of excessive open-market operations, the belief that the reserve banks were designed to compete with, and not to render service to, the member institutions. Many banks felt their capital could be made to earn much more than six per cent, and were unwilling to place it, even in small quantities, in a field where its profit-getting opportunities were thus limited.

Because of these numerous doubts, queries, and objections, because the state of the money market was not such as to create great dependence upon the Federal Reserve, because arguments were based so largely on advantage to the group and possibly not to so great an extent on the self-interest of each bank, it does not appear surprising that the great number of banks, not accustomed to assuming positions of leadership in the banking fraternity, should prefer to await future developments; that, in other words, they adopted the policy of watchful waiting. It is no doubt true that the assumption of this attitude placed the non-member institutions in a stronger strategic position. It was not to be expected at the time of the framing of the original act that the lawmakers would make every 
feasible concession to the State institutions. With more experience in the operation of the system, further concessions could be made later. And possibly the framers of the act had in mind the desirability of holding back something for future bargaining purposes. At any rate, it is probable that the few State institutions which joined prior to the middle of 1917 were those which were strongly impressed by this opportunity of stamping themselves with whatever guarantees of soundness and progressiveness membership in the Federal Reserve implied. Membership was an advertising feature of no mean advantage.

But after the date of our participation in the World War, the situation altered itself abruptly. It was understood everywhere that war finance must increase greatly the demands upon all classes of banks. Not merely was it expected that the general level of commodity prices was destined to advance, but the necessities of military demands must throw greater strain upon our productive and industrial organization. To wait longer in applying for admission might prove costly. Entrance into the Federal Reserve could not be accomplished on the moment; some delay must be encountered while the merits of the application for entrance were being considered. Previously the Reserve Board had rejected many applications because the past record or present condition of the bank was unsatisfactory. Nor was there certainty that indirect aid could continue to be had from the Federal Reserve. The increasing strain upon the banks might place the city correspondent institutions in a position where they must think more largely of their own requirements. At the same time the occasion appeared ripe for some of our high Government officials to base their pleas for membership on patriotic motives. Early in May, 1917, a letter from Secre-

' Cf. Report of the Federal Reserve Board for I9I5, p. I2. 
tary McAdoo ${ }^{*}$ indicative of such appeals was read before the Executive Council of the American Bankers' Association. The following sentences may be quoted from this letter:

The time may come when the financial resources of the country will not be commensurate with the national purpose, if the nation remains half State bank and half national bank in its organization. The State banks will find greater security for themselves, if disaster should threaten, if they are members of the Federal Reserve system; and the system will be irresistibly strong if the State banks unite with the national banks in making them an extremely useful national instrument.

I commend this question to your earnest and patriotic consideration, with the sincere hope that love of our common country should surmount every other consideration and bring about this supremely desirable result.

At the same time it began to appear as if the non-members had gained all possible advantage from remaining aloof. In an address delivered in Chicago in April, ${ }^{2}$ Paul M. Warburg called attention to the fact that the Board had gone the limit in its endeavors to provide favorable terms for the entrance of State banks. He insisted that since State banks profited by the institution they were under obligation to support it.

In the matter of friendly legislation much progress had also been recently accomplished. In the previous year or so some of the few States which had been tardy in enacting the necessary enabling legislation wrote statutes empowering State institutions to become stockholders in the Federal Reserve Banks. These States were Delaware, Idaho, Kansas, Montana, North Dakota, South Dakota, and Washington. Furthermore, Federal legislation of very

'This letter is printed in part in the Commercial and Financial Chronide for May 12,1917, pp. $183 \downarrow-35$.

'Cf. Commercial an! Jinancial Chronicle, April I4, 1917, Pp. 1450-51. 
great importance was enacted in the amendment to the Federal Reserve Act on June 21, 1917. The most important concessions therein granted were the following: ${ }^{x}$

I. Any State bank or trust company desiring to withdraw from membership in a Federal Reserve bank may do so, after six months' written notice shall have been filed with the Ferleral Reserve Board, upon the surrender and cancellation of all its holdings of capital stock in the Federal Reserve bank.

2. Subject to the provisions of this act and to the regulations of the board made pursuant thereto, any bank becoming a member of the Federal System shall retain its full charter and statutory rights as a State bank or trust company, and may continue to exercise all corporate powers granted it by the State in which it was created. ...

The first of these concessions placed in definite statutory form what previously had been merely a ruling of the Board. In case withdrawal should be desired, voluntary liquidation would no longer be necessary. By the second concession guarantee was given that entrance into the system need not result in the loss of rights and powers possessed at the time of entrance, provided these were not in conflict with the terms of the act or the regulations of the Board. And aside from the clauses relating directly to the terms of membership in the system, a further welcome feature of this amendment was the lowering in the legal reserve minima. After these statutory concessions had been granted, the President felt justified shortly afterward in asserting ${ }^{2}$ that "membership in the Federal Reserve system is a distinct and significant evidence of patriotism."

The effect of these appeals, of these statutory changes, and of the altered financial condition of the country was

See Section 9 of the amended act.

- Statement of President Wilson made public through the Federal Reserve Board. See Bulletin, November, 1917, pp. 827-28. 
soon made manifest by an increased membership. It has been remarked that on June 2 I, I9 I 7, the number of member State institutions was 53 with total resources of $\$ 825$,ooo,ooo. By January 3I, I9 I 8, 296 State institutions with total resources of more than five billions of dollars had become members. ${ }^{1}$ By September I, 1921, more than I600 State institutions were members with total resources of nearly ten billions of dollars. ${ }^{2}$

It seems undeniable, therefore, that remarkable success was achieved finally in enlisting members from State banks and trust companies. It is true that the total number of non-member institutions, with resources, enormous in the aggregate, far outnumber those which have joined. Many of these, however, would not be eligible for membership, and many would not add to the strength of the system if they were admitted. It should not be forgotten that a number of applications have been refused, and the effect of these refusals has undoubtedly influenced many other banks, whose financial strength was somewhat similar, not to make applications. It is true that many strong and powerful institutions remain outside the fold, but sufficient success has been achieved to render improbable the danger of warfare between members and non-members. When one recalls that in one matter of the utmost importance to the State banks - the clearance and collection of checks - no concession of principle was made, it appears that the Board should be lauded for its general good tact and administrative efficiency. Few proposals of the sort once most earnestly advocated are now to be heard, proposals which if worked out might have split the country into two rival camps, proposals that non-members establish a country-wide clearing system of their own. Of

- See Bulletin, February I, I918, p. 92.

- See ibid., issue of September, 1921, p. 1078. 
course it may be true that the accretion in membership was merely the by-product of a too liberal discount policy. But this is another problem and calls for special discussion in a later chapter.

One interesting aspect of the State bank membership problem remains for discussion. What has been the effect of the legislative efforts to attract State bank members upon laws governing the operations of national banks? With no concession to national banks their position as competitors of State banks would become less secure. There was danger of stunting the growth of the national banks. To check this danger, legislation was enacted broadening under certain circumstances the powers of national banks. Legislation of this sort was contained in the act of September 26, I918. The import of this can be understood best by quoting an Opinion of Counsel of the Federal Reserve Board as to its application: ${ }^{\mathrm{I}}$

Under the provisions of section II $(k)$ as amended by the act of September 26, 1918, the Federal Reserve Board may properly permit any national bank to exercise any of the fiduciary powers authorized by that section, unless there is some express provision of the laws of the State in which such bank is located which either directly or by necessary implication prohibits national banks from exercising such powers, and even if there is such an express statute, the Board may issue its permit if any State bank, trust company or other competing corporation in that State is permitted to exercise the powers applied for by the national bank.

An indirect result of the problem of State bank membership has thus been to encourage the tendency toward "department store" banking. It is probable that there will be a further development of this tendency in the future. Many national bank directorates feel that the law is not quite fair to their institutions. In many respects,

'See Bulletin, April, 1919, p. 363. 
such as that of prestige, membership in the Federal Reserve serves all the purposes previously requiring national incorporation. These directorates are considering reincorporation as State banks in order to gain the advantage of more liberal legislation. Particularly in the matter of the establishment of branches there is a general demand that national banking law be made more affrmatively liberal. 


\section{CHAPTER IV}

\section{ADVANCES OF RESERVE BANKS - REDISCOUNTS}

The purpose of this chapter is to explain the machinery and conditions under which the funds of reserve banks through the medium of rediscounts may be made available for member institutions. The reader will bear in mind that rediscounting is not the sole means by which reserve banks may employ their resources. Through an amendment to the original act, later to be discussed, reserve banks secured authority for rendering direct aid by discounting the notes of the member banks themselves. Indirectly also, through their open-market operations, further aid may be extended. Our present purpose, however, is to discuss one type only of reserve bank operations, rediscounts, or the discount of paper which originated at a prior date, the parties concerned being in most cases the member bank and one of its clients.

It seems logical to give rediscounts rather than the other operations the place of priority in our discussion. Not for a considerable period after the date of inauguration were reserve banks given permission to make direct advances to member institutions. While reserve banks did possess from the very beginning certain powers of direct dealings in the open market, such functions were not the most emphasized. In the exercise of their open-market powers the reserve banks of ten must assume the position of competitors of member banks; their policies may have been adopted for the purpose of controlling the money 
market, possibly with the result of interfering with the profit-making operations of the member institutions. If conducted, not for the purpose of control, but merely for the sake of securing more complete employment for their resources, these direct dealings may lessen the dependence of the public upon the member institutions. Only in rediscount operations is the character of the reserve system displayed consistently as of a coöperative nature, only then does the reserve system appear as an institution designed to render service to its member banks. Since in the early years of operation every device of sound banking must be employed in order to secure the allegiance of the individual banks of the country; since without their generous support the Federal Reserve must have failed to secure the resources and influence necessary to enable it to function as intended, the helpful possibilities of the system have been the most advertised. To-day a layman, asked to define the functions of the reserve banks, would undoubtedly reply - they are institutions designed to aid member banks by rediscounting commercial paper.

Statutory provisions regarding rediscounts are contained in section $\mathbf{I} 3$ of the act. The general purport of the terms of this section was to encourage sound methods of commercial banking and to maintain liquid the assets of the reserve banks. Accordingly reserve banks may rediscount only paper which arises in the short-time, selfliquidating operations of trade, industry, and agriculture. More specilically the leading provisions of this section were:

(I) Reserve banks are permitted to rediscount paper endorsed by member banks which arises out of and the proceeds of which are employed for agricultural, industrial or comnescial purposes. 
(2) Paper covering merely investments or drawn for the purpose of carrying or trading in stocks, bonds, or other investment securities is rendered ineligible.

(3) The definition of ineligible paper, however, does not cover "that issued or drawn for the purpose of carrying or trading in . . . bonds and notes of the Government of the United States."

(4) Paper drawn for agricultural purposes or based on live stock may have a maturity at the time of discount by the reserve bank of six months. Other eligible paper must have a maturity not in excess of three months.

So much emphasis has been placed upon the desirability that rediscounted paper should comply with these requirements that it is commonly assumed that it would not have been in the interests of sound or conservative reserve banking to have included other varieties of eligible paper. Of late, however, some voices have been heard denying the assumption that eligible paper should be defined thus narrowly. In order that later we may form a judgment as to the desirability of the qualifications contained in the act, it may be well to recall some of the leading objections offered to the rediscount of speculative or investment paper.

First of all, it was believed that these restrictions were necessary in order to keep liquid the funds of the reserve banks. In the course of time it was expected that the loaning power of the reserve institutions would become the ultimate reserve of the country. Far more important then would it be that the reserve funds should be easily available than those of any private bank. Member banks could rely if necessary upon the reserve institutions for aid, but no easily accessible source of relief would be open to the reserve institutions. Their reserves would constitute the last line of defense in a period of threatened liquidation.

I Cf. for instance, Anna Youngman, "The Efficacy of Changes in the Discount Rates of the Federal Reserve Banks," American Economic Review, September, I92I, pp. $463-86$. 
In the second place, there was a general desire to seize every opportunity offered by the establishment of the new system to encourage sound banking methods on the part of the member institutions. Not merely does the strength of the reserve system-depend largely upon the strength of the member banks, but the advantages to the public arising from the formation of the reserve system inight be lost if member banks should be encouraged to invest too large a proportion of their resources in slow assets. From the standpoint, then, of the condition of member banks, every effort should be exerted to maintain the liquid character of the paper in their portfolios.

Certain objections, somewhat of a political character, also lay in the way of the admission of paper arising out of investment or speculative operations. As remarked in a previous chapter the support of the interior banks and of the business public could not easily have been secured for a plan whereby the reservoir of funds for investment and speculative activities could be increased by the use of the contributions of all member banks, large as well as small, metropolitan as well as rural. To repeat a former observation, the Federal Reserve plan was directed largely against Wall Street; its support among a large class of bankers depended, not so much on any sound conviction as to the merits of the numerous technical objections to the oid system, as to discontent arising out of the difficulties experienced by banks of the interior in securing the return of funds invested in 1907 in the securities market of New York City. Allegiance to the reform system could not be secured easily without the guarantee that the surplus reserves of commercial banks should be kept available for the needs of commerce and agriculture instead of swelling in the slack seasons and years the reservoir of stock market funds. Rediscounting of speculative paper must be refused. 
What, moreover, about the inflationary possibilities of the new system? Everywhere was it understood how, by the concentration of reserves and the resulting pyramiding of credits, the reserve system would make possible vastly cnlarged amounts of bank advances. Would expanding credit grants, thus rendered possible, exert a lifting influence upon the general price level and exaggerate the difficulties already generally attributed to a faulty standard of deferred payments? In answer to such queries there was a general denial by the members of a certain school of currency students of any direct connection between expanding grants of commercial credit and the general level of commodity prices. This school argued that only when bank funds were borrowed for investment or speculative purposes the cause of a resulting higher level of prices could be attributed to any enlargement of bank advances. The real.danger lay in pouring too large a proportion of the country's banking resources into the investment reservoir. Possibly the clearest brief statement of this point of view is that of Professor C. C. Arbuthnot in the American Economic Review for December, I920. His statement was made for another application, but well summarizes certain views earlier expressed regarding Federal Reserve policy. To quote from his argument:

In the ordinary processes of business the credit of commercial banks is used to assist in the purchase and sale of marketable goods. It takes the form of short-time notes which are to be paid from the receipts from the sold goods. The extension of credit to permit buying is accompanied almost simultaneously by an offer in the market of the salable commodities. The effective demand for goods thus made possible is accompanied by the supply of goods. The equilibrium between supply and demand is not seriously disturbed and the extension of credit has no

${ }^{x}$ Cf. pp. 779-80. The subject of Mr. Arbuthnot's article was "A Stabilized Dollar." 
lifting influence on the general level of prices. As long as commercial bank credit serves this purpose there is no inflation.

As will be indicated later, this view does not harmonize with that of the writer. Nevertheless, with various modifications and refinements it represented the view of many. Since it was inevitable that the reduction of reserve minima under the Federal Reserve would expand greatly the potential volume of bank credit, acceptance of this view necessitated a careful attempt to restrict the use of reserve resources for investment purposes.

The above fears of price inflation had to do with the probable results of too great advances to the investment market. But when bank funds are employed for another purpose, the withholding of goods from early consumption - for commodity speculation, in other words - there was general agreement as to the lifting influence upon the price level of the bank funds thus advanced. Clearly, it was unanimously agreed, reserve funds must not be made available to the commodity speculator.

Many controversial points were involved in the arguments stated above. It is the writer's belief that to-day there is an even greater tendency to dispute the validity of some of these tenets. But their truth accepted, the practical problem became that of framing measures which would effectively discourage the use of reserve funds for speculation or investment. In other words, it was a matter of devising tests or standards according to which the commercial character of the paper offered for rediscounts could best be determined. Several possibilities received some attention in this connection. First, admissible paper must be of the double-name rather than of the single-name type. Second, statements of conditions of the maker's assets could be required. Finally, in a more informal way, rediance could be placed upon the knowledge of the applying 
banker as to the purpose for which the funds originally obtained were employed. Let us first turn our attention to the matter of double-name paper.

The case for admitting double-name paper only was based upon a number of arguments. In the first place, its form was such as to offer greater indication of the commercial nature of the underlying transaction. Every operation of trade involves at least two parties. If admission of the indebtedness is evidenced by a draft, the seller of the goods becomes the drawer, the purchaser the drawee. If the promissory note is employed, the payee or his agent is the seller, the maker the purchaser. Since these two parties are always involved in a trade transaction, why not require their names and their combined security in the paper which arises when resort is had to bank funds. In case two-name paper cannot be supplied, there is greater likelihood that in the underlying transaction the purchaser is not to liquidate his account out of the proceeds of the sale of the goods, and the paper is not liquid. If two-name paper can be supplied, there is one indication, not conclusive to be sure, but informative, nevertheless, of the liquidating character of the transaction.

In the second place, it was asserted that single name paper indicates more often lax customs of trade credit. The buyer is more tempted to buy unwisely, the seller to overextend credit or accept bad debt accounts, when the buyer is not compelled to acknowledge immediately his indebtedness. Single-name paper often originates because of the desire of the buyer to postpone the date of formal acknowledgment of his obligation. At the time of shipment and for a certain period thereafter he insists upon being carried on the open book account. Inevitably this delay must increase the likelihood of bad debts, slow payments, expensive collections - in short, irregularities in our trade credit methods. 
As a special irregularity thus created, it was furthermore insisted that single-name paper necessarily gives rise to many duplications. These duplications could usually be attributed to the ability of the buyer to avoid the immediate creation of paper which when discounted would render him subject to a call from the bank. In the absence of careful analysis of financial statements, single-name methods permit the same person to borrow from a bank and from a commercial paper house. Some firms established connections with several note brokerage concerns and sell through them all. The practice of registering with a trust company paper thus sold had its origin in the endeavor of some firms to prove they were not duplicating security in this manner. Some firms borrow largely on their showing of book account and later assign these to selling agents. ${ }^{x}$ If one party could not obtain bank funds without joining simultaneously the other party to the trade transaction, such duplications would become more difficult.

Finally it was contended that the admission of singlename paper must encourage the acquirement of precisely the sort of paper for which there was little foreign demand. In Europe a broad market existed only for prime paper of the double-name type. One of the underlying purposes of the Federal Reserve Act was to create a constant open market for prime paper, both in the home and foreign markets. A broader home market alone would not solve difficulties due primarily to such international facts as excessive gold exports arising from an unfavorable balance of trade. In defining eligible paper a wonderful opportunity existed to correct the situation wherein commercial banks were induced to invest surplus funds in stock exchange activities. But to secure the utmost of advantage

× Cf. E. E. Agger, "The Commercial Paper Debate," Journal of Political Economy, July, 1914, pp. 670-71. 
the requirements of foreign as well as of domestic demand must be taken into account. Single-name paper possessed inferior standing abroad.

Many objections of a practical character, however, must be met by those insisting upon the exclusive acceptance of double-name paper. One of the most obvious, as well as most compelling of these, was the very great lack of good double-name paper in the American market. It has been asserted that at the time of the framing of the act, trade paper arose in less than three per cent of the total credit transactions of the country. ${ }^{x}$ Of this three per cent a very large part consisted of paper arising in settlement of postdue accounts. With double-name paper alone admissible, it was clear that the reserve system could render little real aid to the member banks. If it was not to degenerate in to an impotent and unused mechanism, it must take account of the actualities of the situation and not merely hypothetical or idealistic considerations. Of course the reserve administration would be expected to plan consistently for the development of more sound methods of trade and bank credit. Some time must elapse, however, before any considerable alteration of existing methods could be accomplished.

The above argument could be addressed to practically all the commercial banks of the country. But an especially appealing objection could be addressed to the great number of small bankers on the ground that double-name paper alone must mean discrimination in favor of the large city institutions. In the main, it was argued, the small bank is the bank of the retailer; whereas the wholesaler, jobber, and manufacturer must depend on the urban banking house. Because of the small amount and informal character of his average credit transaction, the retailer

1 Cf. E. E. Agger, "The Commercial Paper Debate," Journal of Political Economy, July, 19I4, p. 663. 
cannot offer his banker any large amount of double-name paper. Except in cases of post-due accounts and slow payments, custom and competition do not permit him to demand notes or to require the acceptance of drafts from his customers. In the wholesalers' transactions, however, wherein considerations of custom must be somewhat less important relatively than those of business efficiency, a future field for the creation of double-name paper was discernible. But what would be the justice and the political expediency of a programme which would admit as eligible only paper contained in large volume in the portfolios of the city institutions? Acceptance of this proposal would compel country banks to purchase paper in the open market in case they desired to draw upon the reserve. But the advantage of such a course of action would be dubious. It is true that rediscounting would increase the bank's reserve. But payment for the paper purchased would tend to tear it down in corresponding degree.

Neither, it was insisted, was there any guarantee that funds obtained by the discount of two-name paper would not be employed for investment or speculative purposes. The funds obtained by the discount of admissible paper might be put to any use desired. In the words of Moulton, written for another purpose: ${ }^{\mathbf{T}}$

It will be recalled, from our previous analysis of the relation of the commercial banking system to the financing of stock exchange speculation, to the outright purchase of securities, to the making of collateral loans for fixed capital purposes and to the activities of invest ment bankers engaged in the marketing of securities, that the funds of the commercial banking system constitute the support for the entire financial fabric, investment and speculative, as well as commercial.

Of course it might be argued that to make this class of paper alone admissible would increase its desirability to

- Financial Organization of Society, p. 633. 
the member banks. But ought not the general liquidity of the borrower's assets and not the form of the paper to determine the right to request Federal Reserve aid. Because of the nature of their operations some borrowers cannot gain possession of double-name paper. If their assets in general are sufficiently liquid, should not their paper be rediscountable? As Sprague puts it: ${ }^{x}$

The fundamental point at issue is whether an analysis of the entire financial position of the borrower or a series of particular transactions affords the lender better safeguards against loss.

It could be contended, furthermore, that discrimination in favor of double-name paper might tend to increase the volume of unsound paper. Eligibility for rediscounts is purely a matter of arbitrary definition. Nevertheless, it might become one of the principal bases offered in the open market for testing its worth. Single-name paper, because of the possible misuse of the funds, because of the fact that only one party is responsible, puts the purchaser on guard. $\mathrm{He}$ is not nearly so likely to avoid the usual safeguards of examination and inquiry when his paper is not of the sort encouraged by the definition of eligibility. In the discount of two-name paper, no margin of collateral over credit obtained would usually be required.

In a pragmatic sort of way, some measure of truth may be contained in this objection. Too much attention to form might lessen dependence upon careful analysis of the borrower's condition. If such abuses should appear, however, the method of correction would be easily available. Merely let there be redoubled devotion to the usual safeguards. In Warburg's words: ${ }^{2}$

It has never been contended by the champions of the trade

I See O. M. W. Sprague, "The Federal Reserve Banking System in Operation," Quarterly Journal of Economics, August, 1916, p. 649.

2 See Bulletin, July 1, 1918, pp. 604-06. 
acceptance that these acceptances should be bought by any one who has not familiarized himself thoroughly with the financial condition of the maker of the paper; he should take this precaution just as if he were buying a single-name note, and as long as he does that there is no reason whatever why he should not be capable of judging solvency and standing from the statement of a borrower who sells the trade acceptance he receives just as he can from the statement of a firm which borrows only on its own note.

Admonitions of this sort, however, were frequently sufficient to lessen the ardor of many advocates of doublename paper. It was expected by many that a change in the form of trade paper must lessen the need of tedious and careful examination. When it became apparent that a mere change in form could not accomplish everything, there was a marked reaction to the view that the main prerequisite of eligible paper must be the general character of the borrower's assets.

As a final objection to the sole admission of two-name paper, it was argued that its use would transfer part of the work of rating the credit of the buyer from the bank to the selling merchant. Under the single-name paper methorl the bank must satisfy itself regarding the standing of the borrower (the buyer). Under the double-name plan the borrower's ability to obtain credit would depend in the first instance upon the seller's rating of the buyer. Because of the addition of the seller's contingent liability in the bank borrowing, dubious trade paper might become the basis for bank credit. In other words, it was insisted that the buyer's bank ordinarily possesses superior means of testing the buyer's solvency to that of the seller of the merchandise.

Undoubtedly there was a good deal of force in this argument. But it merely emphasizes the necessity of careful analysis of the standing of the buyer as well as of the seller. It also brought into clearer relief the viewpoint that the 
principal consicleration was the credit rating of the parties and not primarily the form of the paper. There did not appear to be sufficient warrant for the absolute rejection of single-name paper. Accordingly, the principal statutory provision relating to eligible paper makes the test, not the form of the paper, but the purpose for which the proceeds have been or are to be employed.

But were there not certain other feasible means of increasing the use of trade paper? Could not less strict qualifications and less complete information as to the nature of the transaction be required in the case of doublename paper? In view of the difficulties just disclosed regarding the dangers of insufficient examination, such a course would appear extra-hazardous. But if not this, could not the total volume of rediscounts obtainable by one member bank be made the greater in cases where the applications were in large part double-name paper? Objection to such a policy was the probability that some sections of the country would be unfairly treated. Many communities, particularly the rural and the village, could not be expected to originate any large volume of two-name paper. There thus remained the possibility of granting a preferential rate of discount to applications covering the new kind of paper. To anticipate future discussion, the policy of preferential rate treatment has been adopted during a large part of the period of reserve operation.

The Federal Reserve Board's first regulations regarding discountable paper may now be briefly summarized. In an early communication, Circular Number $13,{ }^{x}$ reserve banks were requested to confine their operations to short-time, self-liquidating paper arising from commercial, agricultural, or industrial needs, and to exercise particular care to

I This circular is accessible in convenient form in the Commercial and Financial Chronicle, November 14, 1914, pp. 1416-17. 
avoid furnishing capital merely for investment or speculative purposes. Funds desired for fixed improvements would fall in the ineligible class. The maturities of the paper rediscounted should be well distributed, and the paper should be non-renewable. To quote from the circular regarding the distribution of the maturities:

It is a general rule (in Europe) not to purchase paper having more than 90 days to run. The maturities of these notes and bills are so well distributed as to enable these banks within a short time to strengthen their hold on the general money market by collecting at maturity or by reinvesting at a higher rate a very substantial proportion of their assets. Acting on this principle, the Federal Reserve banks should be in position to liquidate, whenever such a course is necessary, substantially one third of all their investments within a period of 30 days. Departure from this principle will endanger the safety of the system. It is observance of this principle that affords justification for permitting member banks to count balances with Federal Reserve banks as the equivalent of cash reserves.

As a means of determining the self-liquidating character of the paper, the method of procedure is next outlined. The Board was evidently impressed by the desirability of considering more than the nature of the specific underlying transaction, for the procedure outlined to become effective after January I5, I9I5, practically called for a statement of condition of the borrowing firm. Since, however, the Board did not wish to lay down rules which might involve needless delay or difficulty in rediscounting, it was not insisted that a statement of condition be attached to each bill sold to a reserve bank. But it was to be required as a basis of permanent procedure that the original borrower should file such a statement with his member bank. For the time being, certified accountants' statements need not be submitted. It was suggested, howerer, that at a later date these might be required. Even though the statement 
of condition need not be attached to each bill, the paper must bear on its face evidence that it was eligible, and that the seller had filed a statement of condition with the member banks. This evidence might be vouchsafed by the officers of the member applying bank through the means of a rubber stamp.

These regulations were exccedingly exacting, so far, at least, as methods of procedure were concerned. Few of the smaller banks, particularly those in the rural sections, were in position to supply the required evidence that a satisfactory statement of condition was on file. In the face of an almost entire lack of rediscounting, it soon appeared that the severity of these regulations must be relaxed. Accordingly, on January I2, I9 I5, three days before these regulations were to become effective, the Board extended the date from January I 5 to July I 5 of the same year. But the lack of a genuine desire to rediscount still asserted itself and in Regulation B, Series of $1915{ }^{1}$ it was ruled that statements of condition need not be on file in certain types of borrowing where it was believed it would be difficult to obtain them. To be specific, these requirements were to be waived:

I. If the bill bears the signature of the purchaser and seller of the goods and presents prima facie evidence that it was issued for goods actually purchased or sold; or

2. If the aggregate amount of obligations of such a depositor actually rediscounted and offered for rediscount does not exceed $\$ 5000$, but in no event a sum in excess of ro per centum of the paid-in capital of the member bank; or

3. If the bill be specifically secured by approved warehouse receipts covering readily marketable staples.

In succeeding circulars regulations with a similar trend were sent out. In view of the very great desire of the Board to improve the admitted deplorable conditions in the trade

'See Bulletin, May I, 1915, pp. 37-38. 
and bank credit situation, it appears to the writer that the Board cannot be convicted of endeavoring to establish ultra-bureaucratic methods of procedure.

The purposes of the Board's regulations were two-fold. First, they were designed to state the precise terms according to which the more general terms of the statute could be made applicable to individual cases; and, sccond, to lay down rules governing rediscount operations in cases where the statute appeared to be silent. But even the regulations themselves could not be expected to deal specifically with the multitude of complicated cases which must inevitably arise. Accordingly, as a means of disseminating such information, the Board began the publication in its official organ, the Federal Reserve Bulletin, issued monthly first of its own informal rulings, and second of the opinions of counsel in the Law Department. In these we find replies to the inquiries of member banks, reserve bank officials, private individuals, and governmental representatives. By these methods much was accomplished in the way of harmonizing the policies of the various district board directorates. To a very marked extent the wisdom or lack of wisdom of the Board's policies is set forth in these pronouncements.

The difficulties of avoiding confusion and inconsistencies in these rulings are easily apparent. To consider that prime difficulty of fundamental application - when is an operation commercial and when is it merely investment in character? A distinction, such as this would involve, could not be set up by any generally accepted method of economic reasoning. Fundamentally this query touches a problem which has never been withdrawn from the field of theoretical economic controversy - what is capital? Ever since the precepts of the science of economics have been formulated systematically, the masters have quarreled 
over the proper means of delimiting this concept. To-day opposite viewpoints are still displayed. One school would define capital from the point of view of the form of the good - whether or not it is of a kind primarily applicable to the creation of other consumable goods. The other school would define solely from the acquisitive, individualistic point of view. Thus capital comprises those goods, no matter what the form, which are employed not to provide direct psychic income, but rather to enable the possessor better to derive a money income. This fundamental difficulty appears again and again in the determination of eligible paper.

Many less far-reaching criteria were current also in I9I4 regarding the proper definition of commercial paper. One of these was this - it is paper the proceeds of which are employed in order to acquire readily salable goods. The note of the coal dealer to secure the funds for the purchase of coal to be speedily resold to his customers, of the fruit buyer to acquire fruit for his current sales, would be eligible commercial paper. But what about paper arising in the individual's desire to acquire tracts of standing timber? The timber as well as the timber land might be sold speedily, yet the individual owner. might have in mind more or less permanent ownership. The nature of his possession might create no hardship in holding permanently. Unlike the coal or the fruit, the timber would continue to improve in physical quantity. There would be much more likelihood of its being held indefinitely than in the case of the coal or of the fruit. But should the paper be refused merely because the asset of the borrower and accordingly the security for the bank improves?

In this case the existence of another quality of standing tracts of timber rendered more easy a statement of the Board's opinion. This extraneous quality enabled the 
Board to base its ruling on the desirability of preserving liquid the banks' assets. Timber is subject to forest fires and severe winds. To quote from the Bulletin for July I, 1915: ${ }^{\mathrm{x}}$

While it is true that there are times when timber lands, that have been thoroughly cruised and reported upon by competent experts, are readily salable, there are other conditions relating to properties of this kind which must be taken into consideration. Forest fires sometimes destroy a good deal of standing timber, and sometimes wind storms greatly diminish the value of such properties.

The precedent would be a dangerous one, as owners of coal and ore lands might ask to have their coal and ore in the grounds appraised on a royalty basis, and ask to have paper, based upon their holdings of such lands, made eligible for discount at Federal reserve banks.

But without the possibility of relying upon this quality of timber land - possibility of great deterioration in physical quality - how much more difficulty must have attended the ruling?

Let us therefore suppose another case in which no such condition exists. What if the contractor wishes to borrow in order to secure funds for the erection of a building? Is his operation commercial, or investment, or even speculative in its nature?

Here again the Board was enabled to rely upon a fact of attending circumstance - whether or not at the time of borrowing the contractor possessed a contract of sale. Thus we are informed by the Bulletin for July, $1920,{ }^{2}$ that the proceeds are for fixed improvements and the note is ineligible in case the paper is that of the owner. But if it is that of the contractor, it may be regarded as commercial in character. Thus another quality of paper is introduced -

'Page 126.

'Page 6yg. 
existence of contract for sale of that which has been acquired or constructed by the use of the proceeds of the borrowing.

But if intention to liquidate quickly is the uniform criterion, the Board must face another difficulty - one which must occasion frequent discontent with the management of the system. One borrower might be the maker of an eligible note, another of an ineligible note, even though in both cases the proceeds were employed to purchase the same sort of a good. In one case the Board held eligible a farmer's note to secure the funds for the purchase of farm tractors. Using this as a precedent, it was insisted ${ }^{x}$ by a corporation engaged in the business of furnishing motor transportation that its notes to secure funds with which to purchase motor trucks were eligible. This corporation argued that its paper was even superior to that of the farmer since the life of a motor truck ordinarily is less than that of a farm tractor. Motor truck paper would be less of an investment nature than tractor paper. Accordingly the Board is here compelled to make a distinction dependent entirely upon a matter of degree. To quote a part of its ruling:

Farm tractors constitute only a small part of the entire equipment of a farm, whereas the motor trucks of a corporation engaged in the business of furnishing motor transportation necessarily constitute a very large part of the corporation's entire equipment. If the notes of such a corporation, the proceeds of which are used to purchase motor trucks, were declared eligible for rediscount by Federal Reserve Banks, the result would be that paper representing in the aggregate a very large part of the corporation's capital investment would be eligible for rediscount, and it would not be reasonable to assume that such notes could be liquidated out of the corporation's current revenues.

× Bulletin, February, 1921, p. I9r. 
Obviously the task of deciding what is and what is not a fixed investment is fraught $t_{j}$ with difficulty. Frequently the decisions do not meet the issue squarely. Dependence upon facts of attendant circumstance must make future rulings largely a matter of following precedent, with the danger of confusion, inconsistencies, and reliance upon arbitrary, discretionary judgment.

But to summarize our conclusions as reached thus far "readily salable goods" is not a concept easily determined and easily applied. In some cases conclusions must depend upon the risks of deterioration; in others, upon the existence of contracts to sell. In others, it would seem to depend upon the extent to which the value of the goods acquired by the proceeds of the borrowing measure up to that of the other assets of the company. Fortunately for the Board, the provisions of the statute inserted the word mere in the prohibitory clause relating to investment paper.

Let us next consider another basis for determining the eligible character of the paper. Are the proceeds to be employed to further some definite stage of production, distribution, or manufacture? If the proceeds are not to be employed in such a way as to hasten their journey toward acquirement by the ultimate consumer, clearly the expenditures were for capital and not for commercial purposes. But in practice it must be very difficult to determine whether a given operation is a necessary part of the process of production or commerce. How classify the note of the dealer who borrows in order to acquire grain or cotton which for the time being at least is not to be sold? Is mere warehousing to be considered a necessary part of the distribution process? If it is thus to be considered, would not dangerous precedents be developed, precedents which might seem to justify Federal Reserve advances for commodity speculation? What if the purpose of the borrower 
was primarily to put himself in a position to create a temporary scarcity by withholding the goods from the market?

No practice in market distribution is more frowned upon by the public than commodity speculation of this sort. In our recent period of unrest over the rising cost of living, much legislation and many administration measures were directed against devices of this sort. Nevertheless, loans to store goods are very essential to the marketing of many crops. The supply appears suddenly on the market, and if credit cannot be obtained by the grower, the crop must be sacrificed at depressed prices. The purchasers, presumably often in a better position to obtain bank capital, would then be in as good a position as the local dealer to withhold from sale for the sake of influencing the price unduly. Rejection of applications based on paper of this sort woulc seem to create injustices as between different classes of grain dealers.

It is obvious that the ideal solution would be for the Board to be guided by the existing situation in the market and not by any easily ascertainable fact of the paper. As long as the goods are not unduly obstructed in their flow to the market, the reserve advances appear to be justified. In the words of the Board, the test is whether the funds are requested in order to facilitate the orderly and regular marketing of the crops. Thus in the Bulletin for December I, 1919, ${ }^{x}$ we read of certain remarks addressed to cotton growers:

The Board has consistently advocated during the past five years the policy of orderly marketing of crops. Assuming that adequate warehousing facilities are available, it seems to be in the interest of the consumer as well as of the producer that staple commodities remain as far as possible in the hands of producers until sold for consumption. This policy gives the producer the benefit of an average price in that he is not required to "dump"

- Page I rog. 


\section{ADVANCES OF RESERVE BANKS-REDISCOUNTS 9I}

his products upon the market in excessive volume, thereby depressing the price to the advantage of favored consumers or of speculators who do not as a rule pass the advantage on to the consumer. Owing to the great number of producers there will always be competition between them to sell, which would not be the case if large syndicates were able to acquire control of the bulk of the crop.

But no matter how wide the difference in results between speculative borrowing and those necessary for the orderly moving of the crops, the determination of the precise situation can never be easy. The eligibility of any single note must depend upon general market and business conditions. Under some situations the note of a grain dealer should be accepted; under other situations the note of the same dealer for an identically similar purpose must be rejected. Day-to-day considerations must govern.

What help can be obtained by following through another criterion? Were the proceeds originally employed in order to purchase goods in form fairly complete, or close to the point where marketable? Or, on the other hand, were the proceeds invested in goods which must be completely altered in form in order to render marketable? If this be the basis of distinction, the reserve funds must render less aid to the production and industrial than to the distributive interests of society. Coal purchased by a gas company is not to be marketed until completely altered in form. Labor purchased by an electric light company emerges in salable condition only in form of electric current. But might not the note of the gas company be just as liquid when the proceeds are used to purchase coal as the note of a grain dealer to secure funds for acquiring grain? Is not the pay-roll expense of the electric light company as specdily contributory to income as the expenditure of the grocery dealer for canned goods? 'The labor employed is not sold, but the products speedily are. It is evilent that 
little aid is to be obtained by focusing attention upon the form of the goods purchased by the proceeds of the note.

Shall another criterion be accepted - the speed with which the borrower should be able to liquidate his loan? Shall it be the shortness of the period within which the expenditures bring in returns which determines eligibility? Should reserve funds be withheld from operations, in all other respects as commercial as any other, in which for technical reasons a longer period than ninety days is required? It is evident that such a course would involve much partiality. As stated in the Bulletin for June I, I915: ${ }^{\mathbf{x}}$

There are many processes of production which take a longer time than 90 days, and while no Federal Reserve Bank should enter into an agreement for the renewal of discounted paper, nevertheless, in cases where the "process of production" distribution covers a period longer than 90 days, there is no reason why a borrower should not renew his 90 day borrowing.

In general, as stated in another connection, "Liquidity should not be tested by standards that are too narrow, arbitrary or inflexible."

It thus appears that no one yardstick is available in determining the eligible character of the paper offered for rediscount. Neither liquidity, nor existence of a contract to sell the product, nor the form of the goods acquired by the proceeds of the borrowing, nor the probable speed of liquidation, alone, is sufficient. Distinction between eligible and ineligible paper must often depend upon mere matters of degree or emphasis. Differences are often only relative. It is pertinent to inquire, therefore, whether in the original act it was not somewhat futile to place so much emphasis upon the commercial character of the paper. Are the distinctions between commercial and non-commercial paper too difficult to employ consistently in practice? Should discriminations have been waived and certain

s Page 74. 
types of investment paper rendered admissible? Queries such as these must be postponed until a later chapter. But this much is now clear: under the present regulations much reliance must be placed upon the discretionary judgment, first of the member bank, second of the reserve bank directorate, and lastly of the Federal Reserve Board. If this be true, it appears desirable to inquire whether other mean s of restricting the unwise use of reserve bank facilities were contained or should have been contained in the statute.

One obvious method of preventing excessive use of reserve funds would be to limit the amount of rediscounts obtainable by any one member institution. Since all member banks contribute to the resources of the reserve banks according to their capital and surplus, their rediscounting privileges might be determined on the same basis. In this way an outside limit could be placed on the extent to which any one bank could rely upon the reserve facilities, and any one bank could be prevented from using funds so excessively as to diminish the power of reserve banks to render aid to other member institutions in periods of emergency.

Such a restriction did not commend itself to the framers of the act. It is true that another statute ${ }^{x}$ prevents a national bank from incurring certain indebtedness in excess of its capital stock. But to the application of this law there are certain exceptions. One of these exceptions ${ }^{2}$ relates to any indebtedness incurred under the provisions of the Reserve Act. It has accordingly been ruled that a member bank may rediscount paper to any amount permitted by the district directorate. It was felt that in periods of emergency the power of the district board to render relief should not be curtailed. In periods of business confidence, it was

'Section $\mathbf{5 2 0 2}$ of the Revised Statutes.

'See section I3, Federal Reserve Act. 
believed that most reliance should be placed upon the good judgment of the district bank directorate. Restriction of rediscounts for any one bank is accordingly a matter of the discretionary power of management.

A second plan would be to restrict the amount of rediscountable paper bearing the signature of any one party. Such a limitation might appear to be much more equitable. Should one borrower of one bank be refused accommodations at a time when the paper of another no more deserving borrower of another bank is admitted? Should not discriminations take account of facts of justice between individuals, rather than primarily between banks? Acting on this point of view, the framers of thestatute prohibited the rediscount of paper bearing the signature of the same name, provided such paper exceeds ten per centum of the unimpaired capital and surplus of the lending bank. To this general statement exceptions are to be made in case of "bills of exchange" drawn in good faith against actually existing values. Furthermore, in order to encourage the purchase and acquirement of war securities an act of limited duration was enacted, according to which, on April I6, I9 I9, the Board ruled it permissible for a reserve bank to rediscount paper of a single borrower to an amount equaling twenty per cent of the capital and surplus provided the excess above ten per cent was secured by a like face amount of Liberty bonds or certificates of indebtedness. ${ }^{x}$

But would the paper of any borrowing individual rediscounted with the reserve bank be included within the limitations of section 5200 of the Revised Statutes. Would the creditor be considered to be the member bank or the reserve bank? In view of the fact that rediscounts must be endorsed by the member bank, and accordingly comprise a contingent liability of the bank, a good case

¿ Cf. Commercial and Financial Chronicle, April 19, 1919, p. I56r. 
would seem to exist for regarding them in this light. But by an Opinion of Counsel it was ruled in the Bulletin for September I, I9I8, that: ${ }^{\mathbf{x}}$

A note or bill rediscounted in good faith by a member bank which is no longer owned or held by the bank need not be included as a liability of the maker to the bank within the meaning of section 5200, Revised Statutes.

The effect of this opinion is to confirm the view that rediscounting offers a process by which a bank may increase greatly its loans to any one client. In case the paper of any one borrower approaches the ten per cent limit, such paper may be rediscounted. In this case it becomes an obligation, not to the member, but to the reserve bank.

A consideration of these various limitations perhaps justifies this general conclusion: provided a member bank possesses a sufficient quantity of rediscountable paper, effective limitation of the rediscounts must depend almost solely on the good judgment of the district directorate and the Federal Reserve Board. Restraints of a direct nature, arbitrary refusals to accept the applications of certain classes of paper, depend largely upon the reserve directorates. Indirect restraint, those relating to the cost of rediscounting, depend ultimately upon the Board, because of its power to review rates of rediscount. The development of the reserve system is thus largely a story of management. Statutory provisions reduce themselves in large measure to the discretionary judgment of direction. The most important restrictions relate to the prohibitions on speculative and investment paper. But for the most part the Board's rulings and regulations have been exceedingly liberal.

It was not contemplated by the framers of the act that reserve banks should lend their facilities to non-member $\therefore$ Page 867. 
institutions. These banks were not rendered subject to examination by the Federal Reserve Board and make no contribution to the capital of the reserve institutions. To rediscount this paper must destroy one of the principal incentives to membership in the Federal Reserve.

What, however, was enacted about indirect means of securing the use of reserve funds? Could not the member bank accept the paper of non-member institutions and by rediscounting this paper free its own resources? In this way the reserve could be made the indirect source of advances to non-member institutions.

It was felt by the lawmakers that this would be a situation necessitating much discrimination in judgment. On some occasions it might be a service to member banks for reserve banks to aid non-members in this indirect way. Such action might be the means of restoring general business confidence. In other situations, however, such advances might not be necessary and might have the sole effect of discouraging membership in the system. Accordingly, the law requires that, in case the purpose of such applications was to secure funds to reloan non-member banks, the permission of the Federal Reserve Board must be obtained. During the war period, however, matters of Government finance were deemed sufficient to warrant a very liberal application of the statute. For a certain period it was left to the discretion of the district bank directorates to determine whether such accommodations should be afforded the non-member institutions. ${ }^{\mathbf{x}}$

${ }^{2}$ Cf. Bulletin, June I, 1917, p. 426. 


\section{CHAPTER V}

\section{DIRECT COLLATERAL ADVANCES TO MEMBER BANKS}

When the Federal Reserve system began operations in the fall of I9I4, advances could not be made, under the authority of section I3, by direct discounts of member banks' notes. Leaving out of account their open-market operations, reserve banks could grant accommodations only upon the tender of paper which had originated previously in an advance by the member bank to one of its clients. In other words, the reserve bank's portfolio would consist of paper, the makers of which were the customers of the member bank. For the sake of ensuring the safety of this paper and accordingly of the soundness of the reserve banks' assets, member banks were required to endorse the paper offered for rediscount. But the member banks' responsibility was contingent and not direct.

The reasons motivating the lawmakers to discriminate against direct discounts were several. In the first place, the paper accepted would be single - and not double-name. Only the member bank would be responsible for ultimate payment; whereas in the case of a rediscount, the member bank's contingent responsibility would be additional to that of the original borrower. Secondly, rediscounting operations emphasized more strongly the direct public benefits which the reserve system was intended to accomplish. In case of a direct discount for a bank, it might be difficult for many to understand just how the business pulblic was being aided; whereas in the case of a rediscount the 
ability of a bank to finance a specific transaction would seem to depend more directly upon the willingness of the reserve bank to accept such paper. Rediscount operations appeared to bring the reserve banks more closely in contact with the public. Finally, it was feared that direct advances might be dangerous. If the member bank possessed short-time eligible paper, it could secure aid through rediscounts; in case it possessed no such paper, its purpose very likely would be to secure capital for long-time commitments. To refuse to make direct advances would not seem to penalize the institution which held paper of the eligible sort. But it would penalize the bank whose assets consisted largely of investment or speculative paper. Applications for direct discounts would be the resource of those institutions which did not possess eligible paper, and whose assets, therefore, were presumably, non-liquid.

Of these various objections, the last was apparently the most impressive. For one illustration we may quote the following extracts from the reply of John Perrin, Chairman of the San Francisco Reserve Bank, to the appeals of the Orange County Bankers' Association of California for an amendment to the act which would permit direct discounts of member banks' paper: ${ }^{\mathbf{x}}$

Bank reserves under requirements of the old system were at times found inadequate and financial panic resulted. Your resolution seems to us to advocate not only a continuance of the evils of the old system, but, in advocating loans of indifferent liquidity out of diminished reserves, urges a further weakening. It would seem to us that no policy could be more suicidal and none more certain to involve both the banks and their customers in disaster. ...

The development of liquid commercial paper is a fundamental essential of banking progress. In lowering reserve requirements the Federal Reserve Act contemplates that a bank's paper

${ }^{-}$See Commercial and Financial Chronicle, January 22, 1916, p. 300. 
eligible for rediscount with Federal Reserve bank will constitute an important part of its real reserve. This fortification your resolution would sweep aside, though it should be clear that while the Federal Reserve bank may convert shortly maturing liquid paper into means of payment it has no power to convert a non-liquid loan in to one which will speedily convert itself into a money reserve.

If direct discounts should be made to members who did not possess the necessary amount of eligible short-time paper, the truth of the above statement would be clear. But might not a member bank desire frequently to offer its own note even though its portfolio did contain liquid admissible paper? Might not a bank find direct discounts more convenient and feasible? An affirmative answer to this query might be based on the following grounds:

(a) The member bank might wish to borrow for very short periods of time. 'To discount customers' paper of longer maturity would subject the applying bank to the heaviest discount applying to the paper with longer maturity. Rather than submit to this heavier charge, the country bank, in particular, might continue to seek aid from its city correspondent instead of applying to the reserve bank. Such action would render it all the more difficult for the reserve system to extend its membership and improve its prestige and power to regulate the money market.

(b) In the second place, it was argued that direct discounts would reduce greatly the labor of computing interest on many small notes. Discounts would have to be figured only on the member's note; when this note fell due, it could be paid off and the collateral, consisting perhaps of customers' paper of various maturities, could be returned.

(c) In the third place, direct advances collateraled by customers' notes could be made to offer some margin of security to the reserve bank. The face value of the collat- 
cral could be made higher than the amount of the advance. In the case of an uncollateraled rediscount, there could be no margin of security over the advance of the reserve bank.

With the lessons of experience thus indicating that direct discounts, properly regulated, could be supported by arguments relating to safety as well as to those of convenience, a general demand arose for a change in the statute. Accordingly, on September 7, I916, an amendment to the Reserve Act was passed according to which such advances were to be permitted in cases where the member bank's note was limited to fifteen days' maturity and in cases where the collateral consisted either of the kind of paper eligible for rediscount or of Government securities. The specific wording of this amendment was as follows: ${ }^{x}$

Any Federal reserve bank may make advances to its member banks on their promissory notes for a period not exceeding fifteen days at rates to be established by such Federal reserve banks, subject to the review and determination of the Federal Reserve Board, provided such promissory notes are secured by such notes, drafts, bills of exchange, or bankers' acceptances as are eligible for rediscount or for purchase by Federal reserve banks under the provisions of this Act, or by the deposit or pledge of bonds or notes of the United States.

The reasons for the inclusion of the several restrictions on direct collateral advances should be clear: Unless the objection of rendering the reserve assets more non-liquid was to hold, member banks should possess paper of an eligible sort. If they held such paper, it would be no hardship to require them to forward it as collateral for the advance. The basis of limiting the maturity of the member's note seems obvious, likewise. If the previous difficulty was need of funds for a period shorter than the maturities

:See section 13 of the amended act. 
of customers' paper, member banks could not object to the limitation of fifteen days for the period of advance.

After the date of the amendment, the advantages of direct borrowing frequently proved appealing aside from considerations of convenience. In the seven months or so preceding the outbreak of hostilities, the reserve administration continued to stress, as a means of preparation for any future emergency, the desirability of maintaining the liquid character of the reserve system's assets. Fifteenday paper accordingly was much in demand by the reserve banks. After the outbreak of the war, direct loans collateraled by Government securities rendered great aid in the Treasury's war finance policy. Prior to September 7, I916, member banks which might have acquired Government bonds could not liquidate them by means of rediscount operations. It is true that customers' paper, the proceeds of which had been used to purchase Government bonds, was eligible. But in the Treasury's war finance campaign it proved necessary frequently to rely heavily upon the subscriptions of the member banks themselves. To guarantee banks against loss through the fact that the bond subscriptions might temporarily drain them of funds, member banks were permitted to discount their own notes collateraled by Government war securities at very low rates. On May 25, 1917, for instance, a special rate of from two to four per cent was established at the New York Reserve Bank for member banks' one-day collateral notes arising from the Government's loan operations. This was raised to three to four and one-half per cent on December 7, $1917^{\mathrm{x}}$

For these reasons the use made of the direct collateral advance was great. For the years 1917-20 inclusive the amount of such operations was as follows: ${ }^{2}$

- Cf. Report of the Ferleral Reserve Board for 1917, p. 37 .

Figures were compiled from the Report of the Federal Reserve Board for various years. 


\begin{tabular}{|c|c|c|}
\hline YEAR & $\begin{array}{c}\text { Member Banks Collateral Notes } \\
\text { ACcepted by Reserve Banks }\end{array}$ & $\begin{array}{l}\text { Total Amount of Bills } \\
\text { Discounted }\end{array}$ \\
\hline $1917 \ldots \ldots$ & $\$ 7,742,806, \mathrm{I} 86$ & $\$ 8,968,970,8$ I 8 \\
\hline $1918 \ldots \ldots$ & $33,007,788,230$ & $39,752,933,847$ \\
\hline $1919 \ldots \ldots$ & $72,548,007,733$ & $79,173,969,730$ \\
\hline $1920 \ldots \ldots$ & $55,5^{6} 5,447,000$ & $85,320,874,000$ \\
\hline
\end{tabular}

The direct collateral loans thus came to constitute by far the most important form by which advances were made by Federal Reserve banks to member banks. The great bulk of these loans were secured by United States certificates of indebtedness and Liberty bonds. This is indicated by the following figures: ${ }^{\mathbf{x}}$

\begin{tabular}{|c|c|c|}
\hline YEAR & $\begin{array}{c}\text { MeMBer Banks Collateral Notes } \\
\text { SECURED by War Paper }\end{array}$ & $\begin{array}{l}\text { TOTal AMOUNT OF DIRECT COL- } \\
\text { LATERAL LOANS TO MEMBER BaNKS }\end{array}$ \\
\hline $1917 \ldots \ldots$ & $\$ 5,884,160,624$ & $\$ 7,742,806,186$ \\
\hline $1918 \ldots \ldots$ & $32,142,405,7$ I I & $33,007,788,230$ \\
\hline $1919 \ldots$. & $72,289,834,393$ & $72,548,007,733$ \\
\hline I920...... & $55,410,876,000$ & $55,565,447,000$ \\
\hline
\end{tabular}

The amount of reliance placed by member banks upon the direct collateral loan after the fall of 1916 cannot be stressed too highly. In the first place, after the first issue of Government war securities in 1917, we hear no more about the inability of member banks to take advantage of the reserve system's rediscount facilities because of the lack of eligible paper. Practically every member bank possessed at some time or other considerable quantities of war paper. This sort of an advance, moreover, rendered it easy for the Treasury to carry out its easy-money policy of financing the war. As long as member banks could rediscount their own notes thus collateraled at rates approximately equal to the rates borne by the bonds, and as long

I Figures were compiled from the Report of the Federal Reserve Board for various years. 
as the reserve banks continued to announce their policy of coöperating with the Treasury, they need stand in no great fear of over-subscribing to the war issues. The key to the ability of the Treasury to float billions of dollars of bonds at a low interest rate lay in the ability of member banks to obtain funds on easy terms from the reserve banks. Permitting the notes to be collateraled by Government securities virtually offered an additional means by which funds could be obtained from the Federal Reserve.

Direct advances also rendered it far easier for the banks to carry customers who employed borrowed funds to purchase the war bonds. In case the customer should not complete his payments and the bond should revert to the bank, the bank could liquidate, at least temporarily, by relying upon the reserve bank. In large measure the apparent case with which the Treasury obtained a market for its issues can be attributed to this amendment of September, I9I6. In opposite fashion, whatever evils resulted from the easymoney policy of war finance can likewise be attributed largely to the working of this amendment.

It is true that advances of this sort were limited to borrowings of fifteen days' duration. Nevertheless, the Federal Reserve administration was very liberal in its renewals. The only limitation was that the reserve bank must not obligate itself to make such renewal. ${ }^{x}$ Such an agreement might create the situation in which the maturing note would be paid off out of the proceeds of the new discounts, and the fifteen-day limitation be virtually suspended. But if the requirements of the bank should be due to the emergency character of the general financial situation or to its own liberal subscriptions, there was little doubt but that faith could be reposed in the ability to

- See Opinion of Counsel, Law Department, Bulletin, October 1, 1917, p. 765. 
obtain such renewals. To quote from the Opinion of Counsel of the Board: ${ }^{x}$

If, however, the Federal Reserve Bank is under no such agreement and has the option to require payment in cash, it may at the maturity of a 15-day note discount another for the same amount, secured by the same or substituted collateral, so long as the two transactions are independent of each other.

The question of how far this practice should be encouraged by Federal Reserve Banks is one of policy rather than law. It may be reasonably assumed that the Federal Reserve Banks will not permit its abuse.

× See Opinion of Counsel, Law Department, Bulletin, October 1, 1917, p. 765. 


\section{CHAPTER VI}

THE DEVELOPMENT OF THE TRADE ACCEPTANCE

IN the earlier days of reform-discussion there was a sharp difference of opinion regarding the necessity of a new banking structure. On the one hand, it was argued that despite many imperfections of detail the national banking system would not so frequently have failed to function adequately had there existed in this country a strong controlling bankers' bank. It was insisted that such an institution, by compelling credit-restraint in the years of excessive activity, and by making its resources easily available in time of emergency, could do much to prevent the periodic collapses of the credit structure. This school admitted it was unfortunate that our note issues were based upon the public debt; that our reserves for bank deposits were rigidly defined at law and improperly employed by the metropolitan financial institutions; that the peculiar credit needs of foreign trade industries had been so largely overlooked. Such difficulties as these were admittedly serious; but, nevertheless, it was insisted that a central bank of even moderate resources could do much to moderate the intensity of our credit ills. The major defect was held to be decentralization in reserve holdings, in note issues, and in control.

A second school, however, endeavored to formulate the tenet that no new banking structure was required or was even desirable. In view of the prevailing hostility to the idea of a central bank, it would be futile politically to 
endeavor to devise a dominating bankers' bank. Rather, reform measures should proceed on less ambitious lines. Instead of retaining rigid reserve requirements for deposits, we should provide for elasticity by the employment of a graduated tax on deficient reserves; note issues should be based on the general commercial assets of a bank rather than upon its holdings of Government bonds; foreign trade difficulties should be corrected by bestowing additional powers upon national banks such as the right to accept bills and drafts for international commerce purposes. Finally, as a matter of very great importance, many improvements could be wrought in our commercial paper and trade credit usages. In particular, the attempt could be made to increase the use in commercial transactions of two-name trade paper.

As the controversy progressed, however, these two schools of thought became less sharply differentiated. On the one hand, it came to be more widely perceived that a central bank might encounter serious difficulties unless reserve requirements were rendered less rigid; note issues less inelastic; commercial paper less unsound. On the other hand, it was gradually recognized that the administrative.development of many proposed reforms would require the sponsorship of a large dominating central institution. In particular a more liquid type of commercial paper could be popularized only by a propaganda more effective than any private agencies without power to act could conduct. Was not this the teaching of past financial history? Despite the admitted evils of earlier trade credit methods, the privately controlled banks had failed to develop a wide open market for sound commercial paper. The only hope of improvement lay in the formation of a strong central institution with power to guide and influence. 
Viewed in this light, the campaign for double-name commercial paper becomes one of the most prominent aspects of the reform begun in I9I4. The Federal Reserve banks were not to be solely discount institutions; they also were to be the sponsors and the leaders in the propaganda for more sound methods of commercial banking. In this respect was realized the special contribution of a man who played a peculiarly important rôle in banking progress. Prior to I9I3 Paul M. Warburg was closely identified with credit-reform, and after the passage of the Owen-Glass Bill he was a member of the first Federal Reserve Board. The life of his work survived many changes of political and legislative control. During the period of preparation of the Aldrich Bill, his contribution to the publications of the National Monetary Commission was The Discount System in Europe. In this work the main contrast between European and American banking methods was asserted to be no more the lack of a central bank here than that

The European financial system is constructed upon discounts as its foundation; the American system is constructed upon stocks and bonds as its foundation. ${ }^{x}$

The especial virtue of the European credit mechanism was that its "discount system mobilizes the resources of the banks." 2 Further:

The discount and central bank system enables the Nation to meet these situations by concerted but varying action adjusted to meet each individual case. ${ }^{3}$

The historical causes of present methods of tradc credit are now generally understood. Prior to the Civil IVar the bill of exchange, drawn by the seller against the buyer, was

r Page 23.

2I'age 39

${ }^{3}$ Page 37 . Italics are the writer's. 
commonly employed. The bill, when accepted, would be discounted at the seller's bank. In this way the seller rendered liquid his tracle assets; the seller's bank commonly had available a supply of easily negotiable commercial paper; and the buyer endeavored to conduct his operations in such a way as to ensure his ability to meet his obligations on the promised date.

Gradually, however, this custom was superseded by the open book account system coupled with the offer of a liberal discount for prompt cash payment. This change in methods is explained by the writers as due largely to two causes. ${ }^{x}$ First, the fluctuating value of the dollar in the greenback days rendered tradesmen anxious to close their accounts as soon as possible. Many of them began to offer large discounts to ensure early payments. Since it would not do to obligate the buyer to pay on a future date, his indebtedness would be carried currently as a book account. In this way, two-name trade paper became less and less common. To acquire the funds for his remittance the buyer would offer his banker his own single-name note. Control over trade credit has passed more and more from the hands of the wholesaler's bank and has been lodged in the hands of the local banker. If the buyer did not remit promptly, the seller might be obliged to obtain a line of bank credit. But the paper of the seller was his own singlename, and did not evidence any particular transaction.

IVe are also informed, as a second explanation of the change in trade credit methods, of the development of the work of the traveling salesman in such a way as to alter the legal position of the buyer. When the retailer selected from the stock of the wholesaler as in the earlier days and had an opportunity to examine the quality of the goods,

\footnotetext{
${ }^{2}$ Cf., for instance, E. E. Agger, "The Commercial Paper Debate," Journal of Political Economy, July, 1914, ip. 663-67
} 
the legal doctrine of caveat emptor prevailed. But when he bought from sample, he had a right to insist that the goods conform to the quality of the sample. Before acknowledging his indebtedness he must have an opportunity to inspect the goods. He prefers to be carried on the books in the meanwhile and consequently objects to accepting immediately a draft.

But despite these facts it seems difficult to account for the extremely great scarcity of good two-name trade paper in 1914. It would seem as if the demand on the part of the bank with surplus funds to invest would have created at least a limited field for this type of paper. It would seem reckless to assert that the requirements of the capitalist were absolutely impotent.

Answers to this query may be had, however, by noting the type of transactions to which paper similar in form to the bill of exchange was customarily employed. The draft had been relegated in trade transactions largely to the slow accounts. It was employed in many cases because the seller had become so suspicious regarding the buyer's ability to pay or so impatient at his delay that he demands a definite acknowledgment of the buyer's obligation to remit on a definite date. Two-name commercial paper was in bad company.

Some difficulty, moreover, was experienced frequently in the collection of two-name paper. The drafts were usually not made payable at any bank specified by the buyer of the goods. In this respect its position differs somewhat from that of the modern trade acceptance. Under the Negotiable Instruments Law, recognized in a large majority of our States, a trade acceptance made payable at a specified bank operates in the same manner as a check. Upon maturity, if presented for payment, it will be charged to the account of the buyer provided there are sufficient funds to meet it. 
Banking facts, also, help to explain our inability to develop good two-name trade paper. For various reasons there existed no broad open market, upon which the bank could depend confidently for the sale of its short-time commercial paper. With a strong central bank in existence, directed from the standpoint of public needs, there should not have been the same difficulty in time of emergency of liquidating upon holdings of such paper. Since the time of Andrew Jackson, however, no such institution had existed in this country. It seemed preferable, therefore, in establishing a secondary reserve to invest in securities for which the stock exchanges furnished continuous quotations. This was the basis of Warburg's remark, previously quoted," that "the American system is constructed upon stocks and bonds as its foundation."

Finally, unlike the currency systems of most continental European countries, our banking law placed no premium on commercial paper as a basis for note issues. The bondsecured note issue has much for which to answer.

If, then, it was generally agreed in 1913 that the Federal Reserve must assume a large measure of responsibility for the development of an improved type of trade paper, what were the pertinent provisions of the original statute? It has been stated previously that, while the matter was considered seriously, the lawmakers refused to designate twoname trade paper as the sole type eligible for rediscount. By the terms of section 13 , reserve banks were given the right to discount any of the following: "notes, drafts, and bills of exchange arising out of actual commercial transactions." Eligible paper was to depend, therefore, upon the nature of the underlying transaction and not upon the form of the paper. The concessions of this section (number I3) are confined to certain permissions for the rediscount

\footnotetext{
${ }^{\prime}$ See supra, p. Io7.
} 
of a larger amount of paper bearing the signature of one party than in the case other types of paper are offered. This matter will be discussed briefly toward the close of the chapter.

It is in the open-market section (number $\mathrm{I}_{4}$ ) that we find the principal concession to trade paper. Reserve banks are empowered to purchase "from member banks and to sell, with or without its indorsement, bills of exchange arising out of commercial transactions." This constitutes an evident discrimination in favor of two-name trade paper, since nowhere is the promissory note included in the permissible class of open-market investments. Despite these concessions, however, statutory recognition of two-name trade paper is so limited that its later development must be credited largely to the discretionary acts of the reserve administration.

Before investigating the trade paper policy of the reserve administration, it may be desirable to recall some of the advantages urged in behalf of encouraging the use of a proper type of the commercial bill of exchange. These supposed advantages have been heralded so widely and discussed so generally that we shall attempt to do no more here than to mention them briefly. These advantages may be classified as falling under three heads: first, those of special concern to the seller of the goods; second, those addressed primarily to the buyer; and, lastly, those appealing most directly to the self-interest of the banker.

To the seller the arguments were based on the opportunity of securing almost immediately upon the sale of the goods a definite agreement of the buyer to pay on a certain date, an agreement, moreover, which is couched in negotiable form. Much preferable, therefore, is it to the uncertain and unadmitted obligation of the buyer as evidenced only by the seller's book records. Bad debts and slow pay- 
ments must be lessened by the encouragement of such paper. If payments of the purchaser are speeded up, the bank borrowings of the seller need not be nearly so great ; and the cost of securing working capital is reduced, a factor, moreover, which competition must gradually cause to redound to the benefit of the public. But even if no speeding up of payments is induced, trade paper may still permit the seller to liquidate his assets more quickly. The book accounts of the seller, ordinarily, were difficult to assign. Requests for borrowed funds on the basis of such assigned accounts were interpreted frequently as evidence of the faulty financial position of the seller. Because such assignments were in general disuse, such requests were frequently interpreted as evidence of the impaired financial standing of the applicant. The accepted draft of the buyer, drawn at the time of shipment, should prove much more negotiable, and therefore enable the local banker to make advances even though his own ability to continue to hold the acceptance is doubtful. In other words, the wider the market for commercial paper, the greater the ability to liquidate trade assets quickly.

It has proved somewhat more difficult to convince the buyer of the advantages to be derived by the substitution of trade paper for the open account. It is true that it was easy to argue that any system which would render more certain to the seller the redeemability of his payments receivable must gradually through the force of competition lessen the charges exacted by the seller. But would it secure immediately, in the specific transaction in hand, and with relation to his own competitors, any cheaper terms? It must be borne in mind that the average buyer makes one transaction at a time and is only indirectly interested in improving methods employed by trade as a whole. Too often the propaganda has confused general and long-time 
advantages with those of special and immediate interest. to the buying business man. It may be true also that the trade acceptance method may serve to check reckless buying on the part of the purchaser. But must it not be difficult to convince any one purchaser that his buying habits are so loose as to necessitate his obligating himself to make payment on a specific, definite date? Clearly, arguments to the purchaser have greater force when the appeal is based upon specific individual advantages in the particular transaction in which his acceptance is requested.

Arguments of immediate individual advantage might be the following: In the first place, the buyer who agrees to obligate himself definitely regarding the time of payment improves his credit position with his banker. Often a query of the banker is this - do you accept trade drafts? An affirmative answer may raise the buyer's credit rating. ${ }^{x}$ It is to be admitted, of course, that the underlying explanation of this discrimination is to some extent artificial. The motive of the member banks in encouraging the acceptance frequently has been their desire to secure a type of paper rediscountable with the Federal Reserve at a low, preferential rate. But whatever the source of discrimination, it has been made to apply with increasing force. In some industries, firms which accept trade drafts have been able to insist upon better terms as regards cost of goods and quantity obtainable. These firms conld advance the argument that the acceptance enables the seller to obtain his bank credit at a cheaper rate. Frequently also the acceptance offered a means by which the small and comparatively unknown firms were able to place themselves more largely upon a position of credit equality with those of a more firmly established credit standing.

The advantages of trade paper could also be heralded to ${ }^{1}$ Certain exceptions to this statement will be discussed later in this chapter. 
the commercial banker. It has been remarked that in the past it was customary in the slack seasons for the interior banks to invest in large volume surplus funds in the security market or to place them on deposit with their correspondents in the financial centers. In recent years the work of the note broker had so developed that it was comparatively easy to find an outside market for these surplus funds by investments in short-time commercial paper. But the ability in an emergency to liquidate such paper in advance of the date of maturity was a factor of doubt. Commercial paper investments, sufficiently attractive so far as yield was concerned, did not make a good secondary reserve. The limited open market for such paper explains, therefore, in large measure the huge volume of commercial bank funds regularly invested in the bond market or redeposited with the financial institutions in the stock market centers which bid for such funds.

The danger of these practices was called to the public's attention forcibly in the panic of 1907. The call of the interior banks for New York funds and the general attempt to liquidate quickly on security investments soon caused a general suspension of payments in our financial center.

But correction of this difficulty was not easy. Crisis and financial panics are not ordinarily contemplated as of inevitable recurrence. A change from old methods could be induced only by establishing in normal times a wide open market for commercial paper. The market should be so broad and steady as to offer the same means of liquidating assets as those furnished by bank redeposits and bond investments. Here was the place for the trade acceptance. It was two-name, had its origin presumably in an automatically liquidating commercial operation, and with proper backing from reserve authorities could be converted into cash on occasions of real need. 
It was accordingly possible to make for the acceptance an appeal to all classes of the business public. As to the means which must necessarily be employed to increase its use, it has been stated previously that these depended largely upon the discretionary power of the reserve administration. It was not a matter of slavish devotion to the terms of the statute. Favorable discrimination was confined by the act to the provisions relating to open-market operations and to those bearing upon the amount of rediscountable paper bcaring the signature of any one party. It is therefore necessary to inquire next as to the precise means employed by the reserve management to extend the use of such paper.

In circulars issued November 16, 1914, and April 2, 1915, the Federal Reserve Board outlined certain special privileges and preferential rates of discount to be enjoyed by the acceptance. But the trade acceptance as a distinct class of commercial paper dates its origin to the issuance of Regulation J, Series of 1915. By this regulation the name, "trade acceptance," is devised for double-name commercial paper which conforms to certain requirements. The intention was to find a means of distinguishing this new type of commercial paper from other paper, similar in form, but lacking some of its essential characteristics. For instance, the trade acceptance would be similar in form to a draft arising from other sorts of transactions than those purely commercial. To deserve the title of "trade acceptance" and to enjoy the special privileges which it was proposed to grant it, the paper must conform to the following qualifications: First, it must be drawn by the seller of the goods against the buyer. Second, it must be drawn on account of the indebtedness created by the transfer of the goods and for no other reason. Third, it must be accepted by the buyer under conditions whereby the date of pay- 
ment is made certain. When presented to a reserve bank for discount, such paper must bear the endorsement of a member bank, and must have a maturity at time of rediscount of not more than ninety days. Evidence of the nature of the underlying transaction could consist of a certificate to the effect that "The obligation of the acceptor of this bill arises out of the purchase of goods from the drawer." If it so desired, the district directorate could inquire into the exact nature of the basic operation.

A perusal of the terms of this regulation will suggest the answer to the query as to why this favored class of paper must be made out solely in the form of the draft. Would not a promissory note for the amount of the goods tendered to the seller by the purchaser possess the virtues desired for the trade acceptance, namely, that the paper be double-name and that it arise out of an operation of commerce? Discrimination in favor of the draft depended, not on belief that the form of the paper proves the nature of the operation, but upon the belief that a trade transaction can ordinarily be proved more readily when the paper is in the form of a draft. In case of the draft the seller and not the buyer takes the initiative in making out the transaction. The buyer may postpone so long the making out. of the note that it might be difficult to determine which of a series of operations was financed by any one piece of paper. The draft lends itself readily to the requirement that proof of the transaction be available at the time the paper is presented to the banker. If desired, the bank can insist that the bill of lading and other shipping documents be attached to the note which is offered for discount.

What success has been realized in the endeavor to popularize such paper? Complete and accurate information regarding this matter is difficult or impossible to obtain. Some indication of the use of this paper may be had by 
examining the discount operations of the reserve banks in such a way as to compare the amount of trade acceptances discounted to commercial paper of all classes. Figures are not given for open-market operations, since the volume of these reflects too greatly the volition of the reserve management. What we need to obtain is information indicative of the holdings of member banks. ${ }^{x}$

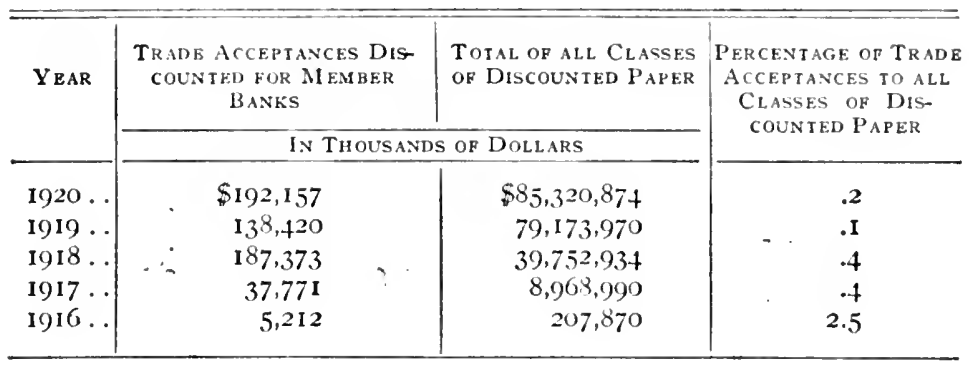

These figures do not indicate any such startling growth in the use of trade acceptances as to suggest a sudden and complete revolution in trade credit methods. Of course the nature of reserve bank operations does not portray with exactness the condition of member bank portfolios. But the larger the amount of acceptances held by member banks, the greater the probability that the proportion of this paper discounted to that of other classes will be large, and vice versa. But in one way these figures may not do exact justice to the acceptance. In the earlier years of reserve operations the trade acceptance was discountable at a lower rate than other classes of paper. Later this preference was eliminated. At no time, however, was there a rate discrimination against the trade acceptance. And the general conclusion derived by examining the figures is confirmed by the prevailing type of literature upon the subject. A very large portion of it attempts to explain

s Figures are obtained from the A nuual Reports of the Federal Reserve Board. 
the nature of the difficulties encountered in the endeavor to secure its popularization. Let us next, therefore, attempt to state some of the obstacles which stood in the way of a wide extension of its use.

A first difficulty was the easily explained hostility of many of the stronger firms in various industries. Many such hesitated to encourage the use of a new instrument which tends to place their smaller rivals on a position of credit equality. In Warburg's words: ${ }^{\mathbf{X}}$

When borrowing on its own note, the strong firm, with wellestablished credit, can obtain larger loans and on more favorable terms than its small competitor, and it is, therefore, in position to finance its purchases and its sales on a more favorable basis than the small firm. It gains the advantage both as to the larger scope of business it can do and the lower interest rate it enjoys. True, it could probably do a larger business than at present by adopting the trade acceptance plan, but by thus adopting the trade acceptance basis small firms would probably profit more in proportion than the larger ones; their handicap would be lightened.

It is necessarily more difficult to secure an inroad for the acceptance by appealing to the smaller establishments. Their customs and methods are not studied so thoroughly by the trade as are those of their larger rivals. The lead must be taken by the leaders. And it could not be expected that weaker establishments, those with a very low credit rating, could be led easily to seize the opportunity of removing their credit disadvantage by adopting the acceptance. These weak firms object to binding themselves to pay on a definite date. Moreover, there has been no desire on the part of the acceptance propagandists to make this type of paper the resort of the weak firm. No paper can classify more highly than the standing of the obligee.

Much difficulty has also been experienced in converting

${ }^{1}$ From address published in part in Bulletin, July, 1918, p. 605 . 
the commercial banker to the new method. To quote Warburg again : ${ }^{x}$

Some bankers assert that in buying a promissory note the mere fact that they are conscious of buying the naked note of a customer furnishes a reason for their feeling obliged to carefully analyze the statement of the customer and to judge the merit of the borrower upon the statement of the latter's financial condition. They allege that this practice is safer than that of purchasing a trade acceptance issued by the same firm, because, as they say, in that case they are likely to rely on the legitimate character of this double-name paper without examining as cautiously as they otherwise would the general condition of the borrower.

The answer to this view has been stated previously. Bankers who purchase acceptances should examine the financial condition of the parties as carefully as when discounting a single-name promissory note. It never was contemplated that a change in the form of paper would eliminate the necessity of such examination. Such a result would be an unfortunate by-product of the trade acceptance movement.

Some firms which employ the trade acceptance are obliged frequently to borrow on their own single-name note. A question which confronts the banker in such situations is whether the use of the acceptance in other transactions impairs the quality of this paper. Some bankers have answered this question in the affirmative by announcing their reluctance to buy the single-name paper of a borrower who practices the sale of his trade acceptances.

The reason given for this view is that whoever buys a trade acceptance acquires the first lien on what would otherwise have represented one of the accounts receivable of the concern which drew the acceptance, and in addition to that lien, in case of

From address published in part in Bulletin, July, 1918, p. 60.4.

Ibid. 
bankruptcy of the drawer of the acceptance, the holder of that acceptance would rank equally with the unsecured note holder as a general creditor for any part of the acceptance which the acceptor might not have paid.

The answer to this contention has already been indicated. Examination and financial analysis are as necessary as in the case of the unsupported single-name note. With proper care this objection should not hold. Unless its privileges are abused, the practice of accepting should improve the borrower's credit rating. It implies a willingness to meet obligations on a definite date and a desire to avoid buying in excess of ability to pay.

All in all it appears that the reserve management has been amply justified in lending its aid to the trade acceptance movement. But the moment special privileges are granted, new difficulties arise. Inevitably attempts are made to create a paper, similar in form to the trade acceptance, but for purposes not contemplated by the reserve administration. Unless such attempts are checked, the distinctive place of the trade acceptance as an easily liquidated type of commercial paper is lost.

One of these objectionable methods has been to employ it in old accounts. Because of the greater proportion of bad debts, in such cases it would not have been surprising had the Board ruled that the draft thus drawn did not conform to its conception of the trade acceptance. The Board might have ruled that the draft must be drawn only at the time of the transfer of the goods. But in this matter the Board's ruling was liberal. In an Informal Ruling we read: ${ }^{\mathbf{}}$

A bill drawn by a retail dealer on his retail customer to finance the sale of goods to that customer is a trade acceptance within the meaning of the Board's regulations, even though it is drawn after the purchaser has failed to remit promptly on an open account.

'Bulletin, January, 1918, p. 30. 
But even though such drafts might be held technically admissible, it is suggested, as a matter of not subordinating "the trade acceptance to the open account by suggesting it as a last resort for bad debts," that reserve banks "should be encouraged to discriminate against them as far as possible. ..."

In the minds of some, doubt existed as to the status of the trade draft on occasions when the purpose of the buyer was not to resell the goods, but to use them for some other purpose. The argument against the admission of these drafts would be that such use destroys their character as paper automatically redeemed out of the sale of the goods. Aside, however, from the difficulty of ascertaining the facts in each case, such a limitation might confine the acceptance too largely to the field of distribution and render it more difficult for the manufacturer and producer to derive advantage through the development of this new type of trade paper. On strictly logical grounds, moreover, it might not make so much difference whether the goods were to be resold. They might be used in such a way as to aid the purchaser in the sale of other goods. They might assist in increasing the liquidation of other goods.

But the basic transaction must be real and not fictitious. Various subterfuges are attempted frequently to enable the drawing of the drafts, which are then paraded as bona fide acceptances. One of the more common of these devices is the formation of subsidiary sales corporations which act as the acceptors of the drafts. In reality the transaction may not involve even the transfer of goods from one department of the business to another. Such bills come close to classifying as those in which the drawer makes out the draft against himself.

In another connection the status of a bill, which in effect was drawn by the drawer against himself, was stated in an 
opinion of M. C. Elliott, then Counsel of the Federal Reserve Board:" "In substance such an instrument is a promissory note, single-name paper and no more." But subsidiary corporations, subsidiary though they be, possess an independent corporate life. Would, then, a "draft drawn by a lumber corporation upon a sales corporation which it and a number of other lumber concerns have organized . . . when accepted, become a trade acceptance, even though the selling corporation is a stockholder of the sales corporation. . . . ."? ${ }^{2}$

The opinion of counsel in this case was couched in very general terms. The status of the paper would depend upon the purpose underlying the existence of the sales corporation. Such paper could be classified as trade acceptance paper if the sales corporation was organized in good faith and not merely as an agent of the selling corporation, to evade the law. Such a conclusion would follow logically from the acceptance of the premise that the transaction must display evidence of some real progress in the process of manufacture, production, or distribution. The transfer of goods from a corporation to a mere agent or subsidiary might not be an essential step in hastening the goods in their journey toward the ultimate consumer, even though the buying corporation did possess an independent corporate life.

Another difficulty concerned the use of the trade acceptance in renewals. It is clear that, if merchants should develop the practice of taking new bills in renewal for those maturing, the distinctive quality of trade acceptance, a bill quickly redeemable out of the sale proceeds, would be destroyed. Such a renewal trade draft would be much akin to that arising in the settlement of past-due accounts.

3 Bulletin, September I, 1916, pp. 462-63.

- Ibid., January 1, 1918, p. 33. 
Accordingly we find the American Acceptance Council insisting that

if an extension of the credit is given, it should be in the form of a promissory note with interest. ${ }^{x}$

Opinions vary considerably regarding the extent to which the acceptance has been thus employed. Regarding this matter the American Acceptance Council states: ${ }^{2}$

So far as we have learned, however, these practices have been largely, if not entirely, confined to houses of minor importance, and they were possibly not surprising in view of the period of credit strain which was endured last summer and autumn, particularly in the textile lines, regarding which the complaints were most general, and the ignorance or lack of appreciation among the smaller and less well-informed commercial concerns as to the proper use of the trade acceptance. A flabbiness of commercial moral fibre may also have been a contributing cause.

These were a few of the difficulties encountered in the endeavor to win for the acceptance a reputation as the purest type of commercial paper. Continuous vigilance was necessary to prevent misuse. But problems of policy also arose which retarded its rapid development. One of these related to the number and strength of the firms whose allegiance to the acceptance should be sought.

In this matter the financial administration was confronted with two alternatives. Either the acceptance must be pushed zealously among all firms indiscriminately, irrespective of their credit standing, and for multitudinous sorts of transactions; or, the propaganda must be begun slowly and cautiously, confining its use to firms with high credit rating and for bona fide commercial transactions. The latter was the only feasible policy. Little improvement over former methods would have been achieved by the adoption of the acceptance in all types of transactions.

'Cf. Commercial and Financial Chronicle, April 2, 192 I, p. 1345.

Ibid. 
In fact, the trade acceptance presented some grave elements of danger if its use became general. One of these over-buying - may easily arise in situations where the banker neglects to take the usual precautions of examination. This depends upon the fact that the trade acceptance is, in form, readily negotiable. Many illustrations of this danger were presented in the crisis of I920-2I. Some receiverships were explained as due to over-buying encouraged in just this way. When the seller hesitated to tie up more funds by sales on credit, he would be requested to continue to ship goods, taking in payment an acceptance, which, it was argued, could be discounted easily. The very liquidity of the trade acceptance created the temptation to sell in excess of the normal volume. When the crisis came, many firms were caught with excessive stocks on their shelves and in their warehouses.

It is true that a more conservative bank-credit policy would have served to check such excessive activity quite irrespective of the sort of trade paper available. But the trade acceptance rendered it easier for the banks to furnish the unsound credits. Bankers had to be impressed again and again with the fact that nothing in the nature of the acceptance justifies refusal to take due precautions regarding the analysis of the credit standing of the parties to the bill. It appears, therefore, fortunate that the propaganda has proceeded slowly and cautiously, that in the beginning the main campaign was begun among the strong, representative firms in lines of industry where the acceptance was expecially applicable. It would have been a mistake, perhaps irretrievable, to have tried to encourage its use among firms of poor credit rating. Care also had to be taken not to push the acceptance too rapidly into industries where the buyer would interpret its use as a reflection upon the soundness of his financial standing. 
With this brief discussion of the difficulties of extending the use of the acceptance, we may now be prepared to offer a more conclusive answer regarding the necessity of a central banking system in our credit structure. Experience seems to have proven that, no matter how great may be the advantages ultimately obtainable from the use of the acceptance, a rapid increase in its use would have brought many evils. Despite the encouragement of an active propaganda and of a preferential rate of rediscount, the trade acceptance to-day is employed relatively infrequently. Without a strong central institution to foster its use by rediscounts and direct purchase, its sound growth must have been even less rapid. No small part of its present attainments is due to the belief that the reserve banks were ready to employ their funds if necessary in the acquirement of the acceptances of prime quality.

A final query yet remains for brief consideration. What limitations exist regarding the amount of trade acceptances discountable by member and reserve banks? Let us first consider the matter of limitations applicable to the member banks in their discounts for their clients.

It will be recalled that section 5200 of the Revised Statutes limits the amount of advances to any one person, firm, or corporation to an amount not exceeding ten per cent of the bank's capital and surplus. But to this general statement there are certain exceptions. Among these is "commercial or business paper actually owned by the person negotiating the same." It has been held that this exempts the trade acceptance, since it classifies as paper of this sort. To quote from an Opinion of Counsel in the Bulletin: ${ }^{\mathrm{x}}$

. . a trade acceptance negotiated in good faith by the bona fide owner would be exempt from the limitations of section 5200

s October I, 1918, p. 974. 
as "commercial or business paper actually owned by the person negotiating the same."

But what is the situation with respect to the amount of trade acceptances permissible for rediscount by a reserve bank? Section 13 of the act limits the amount of paper bearing the name of any one borrower to an amount equal to ten per cent of the member bank's capital and surplus. But an exception to this statement is made by the following clause:

This restriction shall not apply to the discount of bills of exchange drawn in good faith against actually existing values.

The decisive question relates to the question of when a bill will be considered as drawn against "actually existing values." Here there are two possibilities: first, when the bill is discounted before acceptance; second, when discounted subsequently to acceptance.

Before accepted by the buyer, the bill could not be interpreted as being properly secured by the personal obligation of the buyer. Actually existing values must then be proved by the goods themselves. Unaccepted bills do not form an exception to the general provision unless title can be shown to the goods. To quote from an Opinion of Counsel in the March I, I917, Bulletin: ${ }^{x}$

A bill of exchange discounted before acceptance may be said to be drawn against actually existing value, within the meaning of section 13 of the Federal Reserve Act, when and only when it is accompanied by shipping documents, warehouse receipts, or other papers securing title to the goods sold.

An accepted bill, however, may be considered as drawn against actually existing values

if drawn against the drawee at the time of, or within a reasonable time after, the shipment or delivery of the goods sold.

Page 195 . 


\section{DEVELOPMENT OF TRADE ACCEPTANCE I 27}

[But] In this latter case there must be reasonable grounds to believe that the goods are in existence in the hands of the drawee either in their original form or in the shape of the proceeds of their sale.

Bills accepted before sale or delivery of the goods could not be treated as drawn against actually existing values, however, unless the goods have been placed in storage under the order of the drawee. Such goods would not be in the possession of the drawee in original form or in the shape of the proceeds of the sale. The essential commercial nature of the transaction would then be lacking. 


\section{CHAPTER VII}

AGRICULTURAL CREDIT UNDER THE FEDERAL RESERVE

IT has long been recognized that the credit needs of the agricultural classes differ widely from those of the purely commercial or mercantile interests. Among other characteristics agricultural credit needs are relatively long-time, and are subject to pronounced seasonal variations. It might have been expected, accordingly, that a special set of institutions would have been evolved in this country to obtain capital from the investment public for agricultural purposes. For the most part, however, these institutions have been undeveloped here, and the national banking institutions with which the farmer has dealt have been patterned more in accordance with the needs of commerce and distribution. Mercantile and distributive credit requirements are far different from those of agriculture.

Justification for the restrictions relating to real estate loans in the National Banking Law, however, was easy to establish. In most part these restrictions were the result of past disasters which developed when bank funds were employed to promote excessive land speculation. From the standpoint of logic, also, the desirability of limiting loans on real estate security seemed clear. Since the great bulk of the deposits of the national banks are demand deposits, should not institutions whose obligations are payable on call be required to keep their assets liquid? Had not past experience proved the slowness of real estate paper? At any rate, these restrictions were a part of the National Banking Law. 
It has sometimes seemed difficult to account for the marvelous development of an industry thus handicapped in its borrowing facilities. Explanation is twofold. First, credit has been obtained largely from other sources; second, the farmer's past credit needs were relatively limited. Land was cheap and farming could be begun with a limited amount of equipment. As cultivation was conducted on a more and more intensive scale, new capital was required, but this was supplicd largely out of past profits. Farming was creating in large measure its own funds for extensions. The industry was seasonal in its nature, but during the slack seasons employment was furnished by the work of further clearing, building erection, extension of the cultivated area. Goods were brought on time from the local merchant, and, although the price paid for this sort of credit has undoubtedly been high, the farmer has been somewhat slow to perceive that the cost of credit emerged in the price exacted for the goods.

Gradually, however, the dependence of the farmer upon the bank, even for short-term credit, has become more intense. Farm machinery is costly, and the amount required by modern methods is increasing. The horse is beginning to give away to the tractor; this is an cra of the automobile, motor truck, gasoline engine, steam plough, artificial fertilizer, and blooded live stock. Between 1900 and 1910 census figures show a per-acre increase in the value of farm implements and machinery of $6 \mathrm{I} .8$ per cent. Development of new land has become more difficult without credit aid. Very little cheap and easily cultivated land is now available; farm-land extension has necessitated expensive methods of cultivation, such as dry-farming and irrigation. At the same time education and propaganda have become more and more convincing in regard to the high cost of credit obtained indirectly from the store. 
keeper. Under the store lien system the farmer obtaining credit obliges himself to sell his goods through the storekeeper. He obtains customarily low prices on his sales and pays very high prices on his supplies. In an article on agricultural credit Professor E. W. Kemmerer quotes Mr. George K. Holmes, of the United States Department of Agriculture, as follows: ${ }^{1}$

The rate of interest on the liens on the cotton crop of the South, it is safe to say, probably averages 40 per cent a year. All cotton men will agree that it is at least that. The store system of the South is a sort of peonage; that is what it amounts to with the cotton planter.

With similar experiences elsewhere, the desirability as well as the necessity of drawing more largely upon the commercial bank became apparent.

The growing needs of bank credit granted, we may next inquire as to the ability of existing institutions to supply it. Attention has already been called to the provision of the National Banking Law limiting loans on real estate security. But State bank restrictions were usually not onerous. It was often not so much a matter of the legal impossibility of making the credit advance as of the financial undesirability to the banker of the farmer's paper. As previously mentioned, agricultural credit of necessity must be relatively long-time. The farmer is engaged in a producing activity; not until he has a product in salable form is he in shape to make repayment of the loan. A note drawn to obtain funds for the purchase of cattle or seedgrain cannot be redeemed out of the sale proceeds until sufficient time has elapsed for the cattle to be fattened or for the grain to become the harvested crop. The farmer's operations are much more akin to those of the manufac-

' Cf. E. IV. Kemmerer, "Agricultural Credit in the United States," American Economic Review, December, 1912, pp. 852-72. 
turer than to those of the retailer, jobber, or wholesaler. Three months is ordinarily a very short maturity for the average farmer's note.

It should be borne in mind that it may be much more hazardous for the farmer to depend upon renewals than for the retailer or wholesaler. It may be inconvenient for either of the latter to have their notes called. But a forced sale, by marking down prices, is usually possible. Goods unsold exist presumably in salable form. Not until after the harvesting season, however, is the farmer in possession of readily marketable goods.

But is it legitimate for the farmer to depend upon the commercial bank for such credit needs? Has he a right to insist that the commercial bank supply capital not returnable in a very short period? The answer is several fold. Many of his needs are for purposes much more quickly and easily liquidated than the sort of advances which in the early days created the prejudice against real estate loans. Then our difficulties arose in the purchase of land before cultivation was practicable. Loans for the purchase of machinery or cattle are far different in character. But irrespective of all this, the commercial bank supplies much more capital to the merchantile interests for developmental purposes than is ordinarily supposed. The stock and bond investments of the commercial bank have been enormous.

But at any rate the commercial bank may be the only institution available for the farmer. He cannot offer his stock or bonds to the investment public through the instrumentality of the bond house. Neither have there been perfected here coöperative credit institutions for the purpose of appealing to the investing public. In Europe, by way of contrast, such associations have accomplished much. Details of their organization vary. But usually the plan involved the acquirement by the society of the mort- 
gages on the property of the members who desire advances. On the basis of these mortgages, the society offers its paper to the public. The investor is thus protected by the collective security of the members' obligations. But in America orgainzations had not even developed to such an extent as to preserve for the agricultural borrower funds saved by members of his own class. Savings bank investments, built up in part from farmer's deposits, have been made customarily in corporate bonds of industrial enterprises. In the course of time such institutions as the Landschaften in Germany may take root here. But sudden development cannot be expected. In the meanwhile the commercial bank must be organized to offer legitimate credit aid to the farmer.

Not only are the farmer's requirements long-time; they are also subject to pronounced seasonal fluctuations. Banks which commit their funds to industrial undertakings in the off season may find themselves unable to take care of the farmer during the busy spring-planting or fall crop-moving period. Deposits with banks in the financial centers could normally be withdrawn without difficulty. But during the scason of agricultural strain the security market might be temporarily low and render inadvisable liquidation of bond investments. Limitations on the farmer's ability to sell commercial paper in the open market already have been mentioned. The frequent preference of the banker for industrial rather than for agricultural clients may be traced in part to the unsteady credit appetite of the agricultural borrower.

The special needs of the farmer understood, a next inquiry was to ascertain the means by which relief could be granted. Everywhere the hope was expressed that there should be a continued development of coüperative agricultural credit societies. But what rôle should the com- 
mercial national bank play in all this? Of course it was insisted that the legal restrictions of the National Banking Law be modified. It was asserted that the real estate loan limitations were driving business from national banks to State banks, and that attempts to avoid this loss of business explained many subterfuges and indirect methods of evading the terms of the statute. Frequently the stockholders of a national bank would organize a State bank in the same building and under the same roof. The same set of officers would keep the books of the two institutions, direction would be harmonized, clients would be mutual. Only in one respect were they separate institutions, and that was in the fact of their separate corporate life. Borrowers on real estate mortgages would be "recommended" to the "other" bank under the archway. To the extent that the law created subterfuges of this sort, the chief result was to lessen the size of the national banking system and add to the prestige of the State banks.

It could also be argued that the restrictions of the law, in many situations, lessened rather than increased the soundness of national bank assets. National banks could not loan on real estate security, but were permitted to discount the unsupported note of a farmer. Before the maturity of the unmortgaged note, the borrower might execute a lien in another borrowing operation in favor of a State bank. In case of the insolvency of the borrower, the national bank's claim to the property would be inferior to that of the State institution. The national bank could have acquired a prior lien had it been permitted at the time of the loan to demand a mortgage.

But one fact relating to the safety of farm loans seems strangely to have been overlooked by many students of agricultural credit. It is true that in the past some of our most severe crises were due to over-speculation in land. It 
is also true that farm borrowings are for a relatively long period of time and that the commercial bank deposits should be protected by easily liquidated holdings. Still, in past depressions the speed with which agriculture has recovered often has been astounding. Poor years may come, markets or crops may fail, but the nucleus of the farm organization remains intact. It is the exceptional case to find the farm in a good agricultural district totally deserted and rendered destitute of equipment. It is seldom abandoned as may be the case in an unprofitably established factory or shop. And steadily land values have increased. The big drops in this country have been due usually to temporary speculative reaction and represent only momentary oscillations on a steadily ascending curve.

These considerations should not be interpreted as an argument for the total removal of restrictions on real estate loans. The commercial bank must keep its assets in fairly liquid shape; it cannot base its advances on ultimate prospects. But no large proportion of a bank's assets need ordinarily be liquidated suddenly. Would there not be justification, accordingly, for permitting to a limited extent investments protected by real estate mortgages?

But what provisions should have been inserted in the Federal Reserve Act relating to agricultural credit? The reserve banks were to be bankers' banks to guarantee, particularly in periods of emergency, the redeemability of member bank assets. They were to be the ultimate reserve holding institutions of the country. It, accordingly, was a matter of absolute necessity that they maintain their own assets liquid. The paper discountable was to be of the short-time, automatically liquidating variety. What room would there be in the Federal Reserve Act for a provision rendering it possible for a member bank to lend on real 
estate security? Logically none, unless such paper were eligible for reliscount or direct purchase. A change in the law not concerning directly the operations of reserve banks should appear in the form of an amendment to the National Bank Act. Nevertheless, a provision of this sort did appear in the Federal Reserve Act. In adclition to this modification of the previous legal difficulty regarding real estate loans, it would be expected that something would have been attempted in the way of removing the financial undesirability of agricultural paper. Accordingly, certain preferences are granted agricultural over other sorts of commercial paper in the rediscount operations of reserve banks.

We may now quote the provisions of the Federal Reserve Act of special importance to the agricultural borrower. The most important provisions of the statute are three. The first of these, in section 24 , is not related to rediscounting. The original act read as follows in this section:

Any national banking association not situated in a central reserve city may make loans secured by improved and unencumbered farm land situated within its Federal reserve district, but no such loan shall be made for a longer time than five years, nor for an amount exceeding fifty per centum of the actual value of the property offered as security. Any such bank may make such loans in an aggregate sum equal to twenty-five per centum of its capital and surplus or to one-third of its time deposits and such banks may continue hereafter as heretofore to receive time deposits and to pay interest on the same.

Then followed a statement to the effect that the Federal Reserve Board could add to the list of cities in which national banks would not be permitted to make loans. Except for this, this section is not related in any direct way to the reserve mechanism.

This section was later amended. Under certain restrictions banks in the permitted cities may make loans on real 
estate as well as upon farm-land. Also, the bank advancing the funds need not be situated within the same district, provided the real estate or farm-land is "located within one hundred miles of the place in which such bank is located."

The second of the agricultural credit provisions is found in the rediscounting section, 13. Whereas eligible commercial paper must have a maturity of three months or less, notes, drafts, and bills drawn or issued for agricultural purposes or based on live stock and having a maturity not exceeding six months may be discounted in an amount to be limited to a percentage of the capital of the Federal reserve bank, to be ascertained and fixed by the Federal Reserve Board.

This is the most important concession to the special needs of the agricultural interests to be found in the act. The accomplishments under this section later will be considered.

The last of these provisions of special importance to agriculture is to be found in the amendment to the act bestowing upon national banks power to accept certain types of domestic bills and drafts. Since no specific preferential treatment is hereby granted agricultural paper, it might not appear to warrant mention in a chapter devoted to agricultural credit. But the domestic acceptance should prove peculiarly useful in removing many difficulties hitherto encountered in the marketing of farm crops. As will appear more clear later, the bank acceptance is a method whereby the client's bank is enabled to aid him to secure funds from other banks. If the local banker is temporarily without funds and cannot discount the applicant's note, it may agree to accept a draft drawn against it by the prospective borrower. This accepted draft may be peddled around the market and because of the financia! standing of the acceptor should find a ready market. It is as if the local bank had guaranteed the note of the client. 
The farmer is in peculiar need of reaching the outside investment market in some such way as this. The scasonal character of agricultural operations of ten creates a strain too severe for the local banker. But the farmer unassisted has no way of securing the use of idle funds available elsewhere. He cannot have his notes peddled over the country by the note broker. His standing in the investment market is not such as to permit this. In view of these facts it seems strange to the writer that the special applicability of the acceptance to the farmer's marketing problems so frequently has been overlooked.

With these, the pertinent provisions of the statute, we may next inquire as to the agricultural credit policy of the reserve management. Has it adopted a liberal or illiberal policy in the administration of its duties? Inasmuch as a prime function of the Federal Reserve Board is to define eligible paper, we may first test its liberality by examining some of its most important decisions so far as these have to do with the admission of paper to the agricultural class. Undue strictness and conservatism would tend to restrict the willingness of member banks to make loans of needed maturity to the applicant farmers.

A first problem had to do with the interpretation of these words of the statute, "based on live stock." A strict construction might have held "based on live stock" to be synonymous with "secured by live stock." The Board ruled, however, that the farmer's note need not be protected by a chattel mortgage on the stock. " Based on" is thus made to refer to the purposes of the farmer's note. If the funds were borrowed in order to acquire the stock the stock comprises part of the assets of the farmer guar antecing his ability to pay. This ruling mate possible. accordingly, theemployment of less red tape in the advance of funcls to the farmer.

Sec Bulletin, June 1, 1915, 1., 72. 
A second interesting ruling related to the eligibility of notes given by farmers in payment for tractors to be used in agricultural operations. It is to be assumed, of course, that the tractors were not intended to be resold. The main question here was whether tractors were to be classified as a permanent fixed investment. If they were so classified, the farmer's note would not be rediscountable. It would appear as if much justification would exist for such a classification. It is to be expected that the life of the tractor would extend over several seasons, and it could not be regarded as an expense chargeable to the revenues of any one season. Would not expenditures of this sort correspond to those invested in permanent drainage improvements, in silos, and in buildings?

The act, however, stipulated as eligible paper that based upon live stock. Would it be possible to show the similarity of tractor paper to that of live-stock paper? If the law was to be construed strictly, this would appear to offer the sole means of holding such paper agricultural. This means was seized upon by the Board. In the words of the ruling: ${ }^{\mathbf{1}}$

Horses and mules bought for farm work are purchased with several years' use in view, yet there can be no question that a note given by a farmer in payment of a pair of mules to be used in farm work, maturing within six months, is eligible as agricultural paper. Where tractors are used to supplement the work of horses or mules or are used altogether instead of these animals, it seems to the Board that notes given by farmers for the purchase price of tractors, and maturing within six months, should be admitted to discount as agricultural paper. . . .

Implement paper, however, would present a situation in which solution could not be found by stressing the similarity to live-stock paper. Very early the Board was compelled to decide hetween a wide and a narrow con× Bulletin, April I, 1918, pp. 309-10. 
struction of the act. Decision in this matter comes closer to indicating the desire of the Board to render as available to the farmer as possible the facilities of the reserve system.

The Board admitted ${ }^{x}$ that it was

a very close question whether agricultural implements are to be considered as permanent improvements or as a part of the cost of operation.

But as ground for liberality

it must be considered that machinery of this kind is not of a permanent character. It wears out rapidly and in most cases has to be replaced within a comparatively short time, so that it may be assumed that a certain amount of money would be spent annually and regularly for the purchase and replacement of machinery of this kind.

It seems to the writer that it is extremely doubtful whether in other situations so much stress would be placed upon the fact that capital expenditures may be distributed fairly evenly over a series of years. Woukl a manufacturer's notes be eligible for the purpose of constructing buildings in such a way as to keep the erection costs approximately equal from year to year? Would the equipment notes of a railroad company be eligille because the replacement costs for rolling stock might display yearly uniformity?

Prophetic vision is not required to answer these queries in the negative. The real intent of the Board appears to be expressed in the following: ${ }^{2}$

As the Board by its regulations does not desire unnecessarily to restrict, but rather to encourage, the facilities to be given, ats far as that may be done consistently with prudence, it would appear that the wider interpretation in this case should $x^{2}$ given. . . .

'Bulletin, February 1, 1916, p. 67 .

I Ibid. 
Certainly in such cases the burden of doubt is not placed against the farm borrower.

Would it make any difference, however, who was the presenter of the note for discount? Would the Board be obliged, for instance, to refuse to admit as agricultural the paper presented by a dealer, and insist that the maker, the farmer, must be the presenter of the paper? In case the farmer had given his note to the dealer, which note had been discounted, would eligible agricultural paper have been created? Or, since the facilities are granted to the dealer and not to the farmer, must it not be classified as non-agricultural paper?

It is clear that the purpose of the act was to give "special facilities to farmers." I The question, then becomes this - How can these facilities best be granted? In certain situations the farmer might be accommodated to advantage by encouraging the method of note-giving to the dealer. Such a note would be double-name, and very likely would be discounted at a cheaper rate than the farmer's own single-name note. The Board ought not to insist upon the more expensive means of financing agricultural operations. It ruled accordingly that to classify as agricultural paper, the maker of the note need not be the presenter. ${ }^{2}$

But let us return to other cases in which the question at issue was whether or not the expenditure was for fixedcapital or long-time developmental purposes. One important problem was the classification of notes given for the purpose of draining and tilling farm-land. How liquid would such notes be? How soon would such expenditures contribute to increased farm :evenues? Questions of this sort might well involve the amount of expenditures pro-

I Bulletin, February I, I9I6, p. 67.

Ibid. 
portionately to the total farm investment. The Boarl's ruling, however, made the decision depend upon the nature of land. In its own language: ${ }^{x}$

cases may arise in the reclamation of swamp lands where such lands could not be treated as farm land until expensive drainage systems have been installed. In such case there is doubt of the eligibility of the notes, the proceeds of which are used for this purpose. Where, however, the land drained is already in use as farm land, the draining may be treated as incidental to the cultivation of the land, and notes given for such purpose may be rediscounted as agricultural paper.

The liberality of this ruling is easily apparent. Questions relating to the amount of such expenditures and their nature, are not even to be raised. The only criterion is whether or not the land previously has been under cultivation. But even in the case of cultivated land, if such operations as draining do not constitute permanent improvements - fixed-capital expenditures, in other words - it is difficult to know what might be. Such paper may vary widely from the automatically liquidating variety.

A similar sort of decision is raised in connection with farmers' paper arising in the purchase of dairy cattle. In one query to the Board it was stated ${ }^{2}$ that the

cows will be used as dairy cattle which will be retained for a considerable length of time 3 to produce milk, butter, checse, etc., and that the loan is not made, strictly speaking, for the "breeding, raising, fattening, and marketing of live stock."

Nevertheless, the Board held such paper agricultural since "live stock includes cows."

It would have been very easy, however, to hold that dairy cows, to be held permanently, were not "live stock" within the meaning of the act. Live stock is ordinarily

\footnotetext{
- Bulletin, August 1, 1918, pp. 7+3-44.

2 Bulletin, March I, I9⿺6, p. I12.

3 Italics are the writer's.
} 
sold when fattened. In this sense live-stork paper is automatically liculudating. Dairy catlle, however, may not be sold, but contribute to income slowly. Their present selling price represents the capitalization of their future carnings. In reality, dairy cattle is as much a fixed-capital expenditure as that required to purchase a buil ling which is to be rented, or a locomotive which is gradually to earn its own replacement cost.

These are some of the more interesting and illustrative of the Board's rulings bearing upon the differentiation between agricultural and non-agricultural commercial paper. Our next query concerns the method of identification of agricultural paper. Has so much red tape been required in the process that the farmer is harassed?

This question relating to implement paper was answered by the Federal Reserve Board, December 30, 1915.' IVe may quote the following:

The nature of the bill, the name of the acceptor, and the name of the drawer would probably indicate that a farmer was the purchaser and an implement dealer the seller of the goods. However, the purchasing member bank will have to satisfy itself in some satisfactory way that the bill is substantially of an agricultural character. A simple memorandum attached to the bill, stating that the bill was drawn in payment of agricultural implements, signed either by the acceptor or the drawer, would probably be considered sufficient evidence by the member bank and the Federal Reserve Bank.

It will be recalled that by the terms of the statute the amount of agricultural paper purchased by a reserve bank could not exceed a certain percentage of its capital stock. The amount of this percentage was to be fixed by the Federal Reserve Board. Some light may be thrown upon the Board's attitude by noting the percentages thus established. In every case this percentage has been fixed at ninety-nine per cent. This appears very liberal.

I Bulletin, February I, 1916, pp. 67-68. 
In still another way a ruling of the Bnard was such as to make more difficult charges that it was ultra-technical or bureaucratic in matters relating to farm creclit. In an informal Ruling in the June, I9 5 , Bulletin, ${ }^{2}$ it held that a member bank need not make an exhaustive infuiry as to the use of funds borrowed in order that the paper might he classed as agricultural. It need only satisfy itself that the primary purpose was agricultural. The agricultural character of the paper would not be destroyed even if it should be established that part of the funds were employed for the support of the borrower's family.

So far as commerce and industry are concerned, the reserve system has never endeavored to regulate the interest or discount rates member banks might exact. In the marketing of farm crops, we find the sole exception. During a portion of its life, reserve banks, in order to facilitate crop marketing, established a discount rate lower than for other classes of paper. But member banks could rediscount at this low rate only on condition that they would pass this advantage on to the borrower. The borrower's paper was not rediscountable if the member bank originally exacted a rate higher than a certain published maximum. This was the special "commodity" rate.

The establishment of a special commodity rate grew out of the endeavor of the reserve administration in thesummer of I9 5 to be prepared for any contingencies which might arise in connection with the marketing of the cotton crop). All were aware of the disaster which befell the South and the entire country the year previous because of the sudden cutting off, at the outbreak of the World War, of the European market for the South's most important article of commerce. Accordingly, a committee of the Boarl sought to inform itself in the summer of 1915 regarding

1 Page 72. 
conditions in that inclustry. It learned that the reduction in cotton acreage had been such that ample storage facilities were available in the South for the warchousing of such portion of the crop as might have to be carried over. Having ascertained that the physical means were at hand for the orderly marketing of the crop, it appeared that the special need was to ensure a sufficiency of bank credit to finance the carry-over.

The committee entertained the view that warehouse receipts for cotton, grain, and other staple non-perishable agricultural products of a readily marketable character, form an excellent basis for bank loans. ${ }^{\mathrm{I}}$

Accordingly, on September 3, I9 I5, the Board issued regulations according to which notes secured by non-perishable staples receive the benefit of the low special rate.

Since the Board was especially desirous that the advantage of this low rate should be passed on by the member bank to its customers, it was provided that only paper should be eligible for rediscount at the special rate upon which the member bank's charge was not more than six per cent per annum inclusive of all commissions. This special rate was not to be applied exclusively to cotton, but might serve for other staple commodities such as grain, cotton, and wool. The rate might be adopted by any reserve bank, and was not confined to any one district.

To illustrate the manner in which credits might be granted, the following selection is quoted from a statement by the Secretary of the Treasury on September 3, I9I5:2

A borrower asks his local bank for a loan on his note, secured by warehouse receipts for cotton. If the bank is satisfied that the cotton is in a responsible warchouse, properly insured, and that the note is good, it may make the loan. If the local bank

× Cf. Report of the Federal Reserve Board for 1915, p. 7.

'Bulletin, October I, 1915, p. 301. 
charges the borrower, a rate of interest, including commission, not exceeding 6 per cent per annum, it may inclorse the note over to the Federal reserve bank of its district, and the Federal reserve bank may advance to the local bank the full amount of the loan. The rate of interest which the Federal reserve lank will charge the local bank will be sufficiently low, say 3 per cent, to enable the local bank to make loans at a rate of interest not exceeding 6 per cent per annum, and have a liberal margin of profit on such transactions.

The principal problem relating to the applicability of this special rate was that of the definition of "readily marketable staples." By this phrase, the intent was merely to confine the use of funds obtained from the reserve bank to goods capable of being graded, and for which a wide market usually existed, a market not ultrasensitive to changes in consumers' whims and tastes. In one ruling it was held that ${ }^{\mathbf{x}}$

Potatoes, properly graded and packed and stored in a weatherproof and responsible warehouse, as evidenced by its receipt, would undoubtedly constitute a readily marketable, non-perishable staple within the meaning of the regulation.

\section{Although the}

so-called commodity rate was established some time ago in order to give a preferential rate particularly to farmers cluring the crop-moving season ${ }^{2}$

it was ruled that manufactured goods, such as cotton yarn and flour, were staples within the meaning of regulations dealing with this class of paper. ${ }^{3}$ But such manufactured goods must be non-perishable and have a wide ready market.

They must be goods generally produced and well estahlished in commerce, not an extraordinary or unusual commodity for which there is no ready market.

Cf. Bulletin, August 1, 1917, pp. 614-15.

a Bulletin, January I, I9I8, p. 3 \%.

3 Sec Regulations for Series of 1915 and Bulletin, October 1, 1916, p. 523. 
The use marle of the commodity rate is indicated by the following figures: ${ }^{x}$

$$
\begin{aligned}
& \text { September 8, I915, to December 3I, 1915....\$10,315,000 } \\
& \text { January I, 1916, to December 31, 1916.... 16,813,200 } \\
& \text { January I, I917, to December 31, I917 .... I1,244,27 I }
\end{aligned}
$$

These figures display only limited reliance upon this special rate. In the Report of the Federal Reserve Board for I9I5 we read the following: ${ }^{2}$

The effect of the commodity paper regulation was mainly anticipatory and protective. The certain assurance that whatever funds might be necessary for the gradual and orderly marketing of the cotton crop would be available at moderate rates had an immediate and stimulating effect on sentiment.

But as the cotton market improved after the fall of 1915 , and as general ease in the money market prevailed, it no longer seemed desirable to offer this special rate. Accorrlingly, we read in the Bulletin for January, $1918,{ }^{3}$ that it was merged with the general commercial rate. The principal significance of the special commodity rate appears to the writer to consist of its indication of the friendly attitude of the reserve administration toward the credit needs of agriculture.

Let us now consider the matter of the rate of rediscount on six-months agricultural paper with a view of comparing them with commercial paper rates of lesser maturity. On account of the many different rates, and the changes in the basis of classification from time to time, as well as the fact that differences existed between the rates of the various reserve banks, it would be onerous to endeavor to state these results in tabular numerical form. But the following observations may be made:

I Figures obtained from the Annual Report of the Federal Reserve Board.

2Page 8.

3 Page 30. 
I. From November I6, I9I4, to January I, I915, the six-months rate exceeded the rates on shorter maturities never by more than one half of one per cent. In many districts there was no differentiation on the basis of maturities.

2. On January $I$, I9I6, the average rate in the twelve districts on agricultural and live-stock paper maturing after ninety days was five per cent. The corresponding average for the twelve reserve banks on 6I-90-day paper was $4 \mathrm{I} / 6$ per cent.

3. On January I, I9I7, the average rate on agricultural and live-stock paper maturing after ninety days was 4 7/8 per cent; 6I-90-day paper averaged 4.2 plus per cent.

4. On January I, I9I8, the average rate on 6-months paper was 5. I per cent. Corresponding average on 6I-90day paper was $45 / 8$ per cent.

5. On January I, I9I9, the average rate on 6-months agricultural paper was 5.27 per cent. The corresponding average on 6I-yo-day paper was 4.79 per cent.

6. On January I, I920, the average rate on commercial and industrial paper maturing within ninety days was 4.79 per cent. 'The rate on 6 -montks paper was $5 \mathrm{I} / 8$ per cent.

7. October 3I, I92I, the average rate on ninety-day plus paper was $52 / 3$ per cent. Corresponding rate on 9oday paper was the same.

8. At no time has agricultural paper been discriminated against as such. The only discrimination has been that due to the length of the maturity. Agricultural paper maturing within ninety days has been discounted at the same rates as other commercial paper. lart of this period, a preferentially low rate of discount was available to the member bank offering a certain type of commodity paper. There has been displayed no hostility against the agricultural interests in the Reserve board's rate policy. 
With this conclusion reached regarding rates, it becomes difficult to convict the Federal Reserve Board of any failure to recognize the legitimate needs of agriculture. In many cases it has been shown that the definition of eligible agricultural paper has possibly been something more than fair. Bureaucratic methods of identification and certification have been conspicuous by their absence. At one period, agriculture, by means of the special commodity rate, was given a special low rate under conditions whereby a maximum rate was fixed for member bank charges. Liberality was displayed finally by the Reserve Board in determining the percentage of each reservebank's resources which might be invested in member bank's six-months agricultural or live-stock paper. Unfairness to agriculture must, if it existed at all, have occurred by means of direct methods employed by the district directorates. By direct methods we refer to the refusals of these directorates to accept for discount or purchase good eligible paper from the member banks. Let us next ascertain, so far as is possible, the extent to which agriculture may have encountered hostility in this manner.

The period in which to search for this hostile discrimination must be that of I92I-2I, the years of deflation in agricultural prices. Nobody accused the reserve management of illiberality in the earlier years. Until the war period the chief concern of the reserve management seems to have been to secure more complete employment for reserve funds. During the war period and for a year fol. lowing the armistice, credit expansion proceeded at an unexampled rate. What, then, does the evidence show regarding the relative treatment of agriculture and other industry in the years $1920-2 \mathrm{I}$ ?

In the Bulletin for August, I92 I,' Governor Harding, of

$\therefore$ Pages $895^{-99}$. 
the Reserve Board, in a letter to Senator Owen gives certain figures bearing upon this matter. Some of these may be quoted:

On July 9, I920, the total bills on hand at all Federal reserve banks amounted to $\$ 2,934,184,000$. On July $6,192 \mathrm{I}$, this total amounted to $\$ 1,832,499,000$, a decrease of $\$ 1,101,685,000 . \ldots$ The total of agricultural, commercial, and live-stock paper on hand, rediscounted for member banks, on July 6, I92 I, was $\$ I, I 26,968,000$ as against a total of $\$ I, 265,243,000$ on July 9 , 1920 , a decrease of only $\$ 138,257,000$, which is more than accounted for by the decrease in the holdings of paper of this kind by the Federal Reserve Banks of Boston, New York, and Chicago.

In other words,

The bank liquidation which has taken place has been mainly in financial and industrial centers, and the figures do not indicate that there has during the past 12 months been any decrease in Federal Reserve accommodations to banks in the agricultural and live-stock districts, but on the contrary there has been a considerable increase.

Similar figures chosen for other dates of I920-2 I point toward the same general conclusion.

But such figures as these do not tell the whole story. As prices decline, the need for credit to accomplish the same volume of business recedes also. In the depression of business in $1920-2 \mathrm{I}$, the decline in agricultural prices proceeded much faster than the reduction of credits. Since in the nine agricultural districts there was no decline in holdings of agricultural paper, it would appear as if in relation to the state of prices reserve funds were leing enlarged considerably for the benefit of agriculture. The fall in the prices of wholesale agricultural products for this period is inclicated by the following group index numbers supplied by the United States Bureau of Labor Statistics: ${ }^{1}$

- Commolities have been regrouperl hy the Federal Reserve Bourd and the index numbers are published munthly in the Bulletsn. 


$$
1913=100
$$

\begin{tabular}{|c|c|c|c|}
\hline \multicolumn{2}{|c|}{1920} & \multicolumn{2}{|c|}{ I92 I } \\
\hline June & $=30 \mathrm{I}$ & January & $=1.55$ \\
\hline July & $=287$ & Feloruary & $=145$ \\
\hline August & $=259$ & March & $=13^{5}$ \\
\hline September & $=232$ & April & $=126$ \\
\hline October & $=\mathrm{I} 9 \mathrm{I}$ & May & $=\mathrm{I} 3 \mathrm{I}$ \\
\hline November & $=I 70$ & June & $=125$ \\
\hline December & $=\mathrm{I} 55$ & July & $=122$ \\
\hline & & August & $=\mathrm{I} 23$ \\
\hline
\end{tabular}

These facts do not answer the question as to the treatment of the farming class accorded by the member banks themselves. But it should be remembered that the reserve manangement has no direct control over member banks' discount policy. So far as its operations are concerned, the reserve system appears to have displayed every desire to lessen the shock of the liquidation of $1920-21$.

It may be true also that the reserve management's general rediscount policy preceding the depression of $1920-$ 2I is to be condemned. However this may be, it will later be shown that ample warnings were given for the rate increases of the fall of 1919 and for $1920{ }^{r}$ that these rate increases were made only when the reserves of the reserve banks were so low as to necessitate restrictive measures. Moreover, the reserve banks' discount rates tended to follow rather than to precede those of the general money market. The causes of the deflation were many; but figures show that the responsibility of the reserve management, so far as the volume of discounts is concerned, was confined to checking the rate of credit expansion. There had to be a stop some time.

In view of these many evidences of exceptional favors, to be found not merely in the statute, but also in the management of the system, it is interesting to attempt to

× See infra, Clapters XV and XVI. 
explain the general discontent with the reserve system manifested by the agricultural classes after the depression of I920-2I. That a genuine feeling of hostility has been created, in the farming districts of the Middle West and South particularly, cannot be doubted by anyone who has had the opportunity of coming into close personal contact with the farmers of these sections. The following explanations are offered:

First of all, the farmer suffered relatively the most of all classes by the general price decline. Index figures for wholesale prices furnished by the United States Department of Labor's Bureau of Labor Statistics show that while farm products fell from a figure of 287 on July, 1920 (I9I3-IOO), to I 22 on July, I92I, all commodities fell in the same period from 262 on July, I920, to I 48 on July, 192I. Retail prices fell even much more slowly. Of all classes the farmer was probably more convinced than any other that the price gains of the war period would be maintained. Encouraged by his political representatives, by editors of agricultural journals, by officers of his organization, he was led to believe that the old order had changed once for all. Instead of creating rainy-day funds for future emergencies, his profits of war-time were employed to finance larger personal expenditures and the purchase of new land and more expensive equipment. In many localities of every agricultural State, land speculation forced prices up to a point where only the most careful husbandry could produce a fair return on the inflated values. The transportation breakdown and high freight rates contributed to the decline in farm-products values. In all this the local banker was not without blame. It was his duty to prevent the use of bank funds for excessive speculation. In the localities where he failed most to assume this obligation, recovery from the depression was most difficult. 
When pressed for credit he did not feel able to grant, the local banker frequently found it possible to throw responsibility upon the reserve management. The local banker pointed to the increased rediscount rates exacted by the district bank, and to warnings of the district directorate. The district bank could refer to the warnings and arlmonitions of the Federal Reserve Board. Political representatives in Congress, often without any real understanding of the nature of the reserve system, added to the pressure brought to bear against the Board. It was a grand old game of "passing the buck." In all this the emergency character of the reserve system was forgotten, as also the exceptional character of the war period. It was assumed that the reserve system was obligated to furnish funds for private profit-making purposes. To the writer it seems unfortunate that this turn of affairs was not anticipated earlier. The mistake of the reserve management (a mistake, however, Treasury policy made it difficult to avoid) lay in permitting the expansion of the post-war period, not in checking it when it appeared about to pass all bounds of safety.

There were also current many misconceptions as to the nature of the reserve system. As previously indicated, the regional character of the system often was overlooked. It was forgotten that the reserve bank in Kansas City is a different bank from that of New York. It serves a different set of industries and interests, and is managed by directors selected by a different group of men. The fact that credits are made available in one district for purposes denied in another does not necessarily indicate sectional partiality. It may mean solely that one reserve bank was previously more careful in its credit grants, and had built up a greater reserve to support new financing.

It may have been unfortunate that in the financial 
centers security speculation could not have been subjected to more strict control. But our methods of war finance rendered this control difficult. We floated our bond issues at cheap rates by placing the resources of the reserve banks at the beck and call of member banks. Until the war-paper holdings of member banks were reduced it was difficult to render effective a policy of credit restraint. Finally the credit situation got out of hand. A check in the rate of increased grants of reserve funds was inevitable. Many mistakes were doubtless made in all this. But they were not mistakes of attempted and purposed discrimination against the agricultural borrowers.

Finally, the farming class, as also others, has failed often to perceive the real character of the sort of operations permitted for the reserve banks. The reserve system was intended to be an institution dealing, with a few exceptions, in paper of a commercial character. Its reserves are the country's final and ultimate. They must be kept liquid. It never was contemplated that the reserve system should supply funds through the discount of paper arising in land or commodity speculation or for long-time developmental purposes. It may be legitinate for credits of this sort to be supplied by such institutions as'the War Finance Corporation or the Federal Farm Loan Banks. The writer would be one of the first to admit the necessity of developing institutions for the sake of procuring for the farmer the funds of the saving and investing classes. But reserve funds are intended for other purposes. The reserve system is a set of regional banks designed to guarantee the liquidity of sound paper of commercial banks. 


\section{CHAPTER VIII}

\section{THE DEVELOPMENT OF THE BANK ACCEPTANCF}

$I_{N}$ a previous chapter mention was made of the importance generally ascribed to the work of popularizing the trade acceptance. Among the anticipated advantages was the devising of a type of paper which should command a broad and steady market and therefore comprise a suitable investment for commercial banks. But in this respect the development of the bank acceptance deserves even greater mention. It would seem that no paper could be more liquid in open-market transactions than that accepted by an institution with the financial status of a bank.

The essential function of the bank acceptance is to substitute for the inferior credit of the individual the more easily liquidated obligation of a bank. Because of the wide market for the bank acceptance, the bank may be able to meet the needs of its customer even though it itself is unable or non-desirous of making a straight loan. Instead of discounting its customer's note and furnishing the funds itself, the bank merely assists its customers to obtain the advance from some other institution. By accepting this draft the bank places the customer in possession of paper which may be sold to some other banking institution. The accepting bank assumes no responsibility until the date of the maturity of the draft. But on or before the date when payment becomes due, the customer is expected to provide funds for the meeting of the draft. This may have been accomplished previously by the opening of a credit in favor of the individual, or by turning over to the bank for 
collection customers' paper maturing at approximately the same date as the bank acceptance and aggregating perhaps a substantially equivalent amount.

In the import trade past events had shown the necessity of the development of the acceptance method. When the seller of the goods resides in a foreign country, it is peculiarly desirable that the importer's bank be permitted to accept the draft. The standing of the importer may not be sufficient to enable him, by means of his own acceptance, to add much strength to the bill drawn by the foreign exporter. Prior to 1913 acceptance powers were not conferred by law upon national banks. Accordingly, when occasions arose which necessitated the substitation of a bank for the American importer as acceptor, reliance might have to be placed upon some foreign banking institution. This could be accomplished by the American bank's issuance to its customer of a letter of credit addressed to some London institution requesting that it accept the bill. Arrangements would be made whereby the London institution would be supplied with funds to meet, on maturity, any draft drawn under the letter of credit.

In several ways this financing through London was not thoroughly satisfactory to American trade and banking interests. In the first place, this method virtually required the American firm to pay two commissions, the one repre. senting compensation for the service of the Americat institution in issuing the letter of credit, the other compen. sation for the London bank in honoring it. The entire service could have been rendered by the American institution had legal authority for the acceptance existed. In the aggregate the yearly charges upon American industry which went to swell the revenues of London institutions were very great. London was securing business which might have been performed by our own banks. 
Reliance upon London increased the difficulty, moreover, of developing the use of the dollar exchange in international transactions. Drafts drawn against English houses must necessarily be couched most frequently in terms of sterling. When the time arrived for furnishing "cover," the American firm would be obliged to provide whatever sum in dollars the prevailing quotations on sterling would make necessary. The risks of exchange fluctuations were borne by American trading interests.

In the endeavor to avoid this loss by exchange, the American firm might make forward contracts for the amount of sterling credits necessary for cover. But this only meant that the risk in exchange was placed on the shoulders of another party. The assumption of this risk was a service demanding compensation. Payment for it represented an increase burden upon American trade.

In the financing of the export trade a similar necessity existed for the bank acceptance. Let us suppose that an exporter in New York ships goods to a buyer in Buenos Aires. Immediately he draws a draft upon the buyer and attaches thereto the shipping documents covering the goods sold. In case the shipper's bank is in position to discount the draft, no difficulty would arise in the financing of the transaction. The seller secures his funds at once, and is liable only in case of the inability of the bank to collect from the purchaser in Buenos Aires.

In many situations, however, the ability of the bank to discount these bills would be limited. The bills ran customarily for a long period of time. Relatively speaking, South American countries have been capital-poor countries. They must buy largely on time. Their industries, moreover, are dependent largely upon agriculture. In years of poor crops or of a depressed foreign market abroad for their agricultural produce, the period of liquidation is 
prolonged. Frequent renewals become necessary. Under these conditions the American bank might feel obliged to refuse a straight discount.

By means of the acceptance, however, the bank may be able to aid the seller to secure the funds immediately in the open market. The exporter draws another draft against his bank, which accepts it under condition that the trade draft will be turned over to it for collection, the proceeds to be employed to cancel the acceptance credit. The bank, either directly or through some other American house, forwards the trade draft with the shipping document to a Buenos Aires correspondent. When the buyer accepts the draft he receives the shipping documents. By this method the American seller is given negotiable paper, which can be discounted in the general market because of the strength given by the bank's acceptance.

Not only was it argued that bank acceptance would enable the exporter to secure his funds quickly, but it was also anticipated that it would offer a means whereby the financing of forcign trade could be deflected from New York to London as money market conditions might necessitate. Regarding this point we read in the Bulletin for May I, I9I5:

The importance of the development of this banking instrument is now beginning to be generally understood, and inquiries which have been made indicate that additional banks are preparing to offer accepting facilities to their customers. From the point of view of the development of a stable market in New York City for dollar acceptances, this is of importance, for such a market depends primarily upon a large, stealy volume and low, steady rates. Several banks and firms dealing in bills have also, largely within the present month, begun to quote forward rates on bills drawn in dollars, so that exporters in distant countries may be able to calculate the comparative negotiable

'Page 53 . 
value of sterling and dollar drafts. This is also of fundamental importance in the development of the acceptance business. When the movement of our exports and imports has been sufficiently standardized through bankers' acceptances, so that it may be facilitated as easily in the New York as in the London market, even though the volume in the New York market may be much smaller, we should be enabled readily in the future, when we wish to protect our reserves or when they are needed for domestic expansion or seasonal movements of commodities, to deffect the financing of our foreign trade from New York to London by raising New York rates above London rates and making it cheaper for the shipper to draw on London than on New York. Conversely, when we are ready to finance it again we should be able, in normal times, to recover the business from London by reducing our rates below those of London. At other times, of course, London may take the initiative in readjusting the rates for one or another of these purposes, just as its rates have been raised substantially during the past 30 days as a protection to its reserves.

In general the bank acceptance was regarded as necessary in order that our financial centers might assume, in the field of international finance, the place commensurate with the importance of American trade and industry.

Most of the above considerations were stressed also in discussions relating to the financing of domestic trade. Aside from the fact that foreign trade involves the translation of the medium of exchange of one country into that of another, distant domestic transactions offer the same problems as foreign. It is still necessary to find a means of substituting bank time-credit for the credit of the individual. But the points emphasized most largely in the days of banking-reform discussion were the aid which the acceptance might render; first, in the campaign to create a broad and steady market for commercial paper; and second, in the equalization in some degree of money rates in different sections of the country. 
In regard to the first matter it was argued that the bank acceptance would do much to standardize the commercial paper available for bank investments. The credit of individuals varies in quality, but paper representing the obligations of banks should possess some degree of uniformity. The bank acceptance offered a means of substituting the one type of paper for the other. If commercial paper could be thus standardized, much would be accomplished in the way of relieving the stock market from the uncertainties of the call-loan market. As an element in banks' secondary reserves it was anticipated that the acceptance might become the most important item. It was argued that this would constitute an advantage for the security investment as well as for the banking interests. Stocks and bonds of fluctuating value should be financed by time loans. In no other way can they be relieved on intimate dependence upon momentary changes in money rates.

As a second advantage, it was urged that the acceptance would assist in the transfer of banking funds from the capital-poor to the capital-rich sections of the country. Previously, such a redistribution in the employment of bank funds was made difficult because of the inferiority of private credit in the borrowing sections. The acceptance offered a means of overcoming this difficulty to some extent in short-time transactions. Eastern banks would be expected to show more willingness to purchase paper accepted by a Western bank than that of a private individual.

Under the terms of the banking laws of some States recognition of the merit of the acceptance had been made prior to the passage of the Federal Reserve Act. In the Report of the Board for the year 1919 we read: ${ }^{x}$

' lage $2 \mathbf{r}$. 
Incorporated banks were first permitted to accept about ro years ago under the laws of some of the States in which they were domiciled.

It is by the terms of the act, however, that national banks are first endowed with acceptance powers. According to the terms of the original statute member banks were given the right to ${ }^{x}$

accept drafts or bills of exchange drawn upon it and growing out of transactions involving the importation or exportation of goods having not more than six months' sight to run.

In view of the arguments previously advanced in behalf of the use of the acceptance in domestic trade, it may seem strange to note that the original act confined its use to foreign-commerce transactions. Explanation for this fact, however, is not difficult to find. In the first place, it was not desired that in the beginning the bank-acceptance method should be pushed among all sorts of institutions. It was hoped that its use might be confined to banks of the highest degree of solvency. As a rule institutions which had been prominent in foreign-trade financing were classified among those of highest solvency.

In the second place, it was perceived that the foreign trade acceptance was necessary in order to encourage the use of the dollar exchange. As long as London banks accepted for international trade purposes, the banker's bill, in the great majority of cases, would be drawn in terms of sterling money. This was a matter which involved rivalry with a foreign banking mart; it seemed especially important that restrictions preventing our banking institutions from competing on even terms with the foreign should be removed.

Finally, the inflationary possibilities of the bank ac'Section $\mathrm{I} 3$. 
ceptance were recognized. As indicated previously the acceptance method offers a means whereby local industries may be permitted to draw upon surplus funds in the outside banking community. There was danger that credits should be offered too liberally; credits not merely in the aggregate, but also in the amount extended to a single firm. Accordingly, the original act confined its use to one single type of transactions.

Subsequently, ${ }^{\mathrm{r}}$ however, the act was amended to permit of its employment in other types of transactions. These were: first, for the purpose of creating dollar exchange; secondly, to finance the domestic shipments of goods; thirdly, to permit the temporary storage of staples pending a reasonably prompt sale or distribution.

The reader of section $\mathrm{I} 3$ may be somewhat confused by the very many restrictions confining the use of the bank acceptance. Some of these restrictions were a part of the original act; others were introduced in subsequent amendments. It may be desirable, therefore, to inquire as to the motives of the lawmakers in inserting these restrictions in the statute. Aside from matters previously mentioned the desire to preserve for the acceptance a distinctive place as a superior type of commercial paper available for member banks' secondary reserves, and the fear of its inflationary possibilities - the following explanations may be ventured. First, it was made available for rediscount or purchase by reserve banks at a specially low rate. For a considerable period after the acceptance regulations were issued by the Board, the rates on such rediscounts were announced as varying between two and four per cent. The minimum figure was considerably less than the average rate on other paper. A consideration determining whether the rate would correspond more closely with the maximum

- By the amending act of September 7, 1916. 
or minimum would be the standing of the firm acting as acceptor. A higher rate would be a means of discouraging the offer of undesired acceptances. As stated by the Board in an Informal Ruling in the November I, I9 I5, Bulletin: ${ }^{\text {x }}$

It is, of course, understood that the Board would not wish to see concerns regarded as eligible acceptors which are not in the habit of carrying on some acceptance business regularly and are not generally of such character and standing as to qualify their acceptance as a banker's acceptance.

As in the case of the trade acceptance, it was to be expected that many illegitimate attempts would be made to gain the advantage of the low rates.

As a second explanation, it was to be expected that the bank acceptance as a superior type of commercial paper would come to occupy a prominent place in the portfolios of reserve banks. In the early days of operation the support of the reserve banks would be necessary in order to encourage its use. Later, large amounts of acceptances would be purchased by reserve banks as a part of their open-market operations. It was emphatically necessary that the reserve banks keep their assets in liquid shape. Precautions were felt to be peculiarly necessary in order to prevent an unduly rapid growth of such paper.

Finally, with certain exceptions, the limitations of sec. tion 5200 would not apply to the bank acceptance. The theory justifying this exception is that an acceptance is not a loan of money. The accepting bank merely lends its credit to the maker of the bill. The bank's responsibility is contingent only and not direct. Because of the remoteness of loss under this contingent guarantee, it was not esteemed necessary to provide for the application of the same laws which govern the straight loan. Accordingly,

s Page 36. 
by the amendment of September 7, 1916, a sentence in section 13 was made to read:

No member bank shall accept, whether in a forcign or domestic transaction, for any one person, company, firm, or corporation to an amount equal at any time in the aggregate to more than ten per centum of its paid-up and unimpaired capital stock and surplus, unless the bank is secured either by attached documents or by some other actual security growing out of the same transaction as the acceptance.

This was a negative way of providing that acceptances thus secured might be made to an amount exceeding ten per cent of the capital and surplus. But if not secured, the liability of the bank, contingent though it be, was considered too great. If law established for the acceptance no such limitation as section 5200 provided for the straight loan, all the greater appeared the necessity of imposing other restrictions.

While discussing this matter intrepretation should be made of the phrase, "attached documents or by some other actual security." It is evident that the documents must be surrendered to the purchaser before the latter can obtain the goods, and that after their surrender the documents are not in the possession of the bank. To cover this situation the following ruling was announced by the Board in the February, 1919, Bulletin: ${ }^{\times}$

It [a member bank] cannot accept in domestic transactions without being secured at the time of acceptance, but may release the security after acceptance upon the execution of a trust receipt or an agreement by the customer that so much of the proceeds of the sale of the goods covered by the security as may be necessary to pay the draft will be deposited with the accepting bank when available and will not be used for other purposes.

Under certain conditions, however, an acceptance would Page 143. 
become for all practical purposes a loan or a discount. Under such conditions section 5200 would apply. One of these situations would be that in which the accepting bank some time subsequent to acceptance purchases its own acceptance.

This practice, the purchase by the bank of its own acceptance, was not welcomed as customary procedure. An acceptance is a means whereby some other bank is to furnish the funds. On certain occasions, however, such action might prove necessary. If no outside demand for the acceptance accurred, the only means of protecting the acceptance market would be for the accepting bank to make the purchase. Such action might be defended on the ground that the acceptance method must not be permitted to fall into disrepute.

Ordinarily, however, such action should not prove necessary. So desirous have the reserve authorities been that the bank-acceptance method should be encouraged for legitimate purposes, and so well fortified have the reserve banks been in their open-market powers, that the market should not customarily fail for prime acceptance paper. Although somewhat handicapped by the slow development of special discount corporations, the acceptance demand has been enlarged recently on the part of other institutions, as, for instance, savings banks. In some cases, furthermore, it appeared that the purchase of the bank's own acceptance was an attempt to evade the limitations of section 5200 and find a means of advancing more to one party than an amount corresponding to ten per cent of the bank's capital and surplus.

By an Informal Ruling, however, announcement was made that such practices could not be permitted to accomplish their purposes. ${ }^{\mathbf{1}}$ It was insisted that acceptances

s Bulletin, January I, 1917, p. 28. 
purchased by the accepting bank must be considered as loans. In such cases the bank's obligation is direct, and not mercly contingent.

The acceptance method, furthermore, contemplated that the acceptance credit would be eliminated by remittance of "cover" to the bank on or before the maturity" of the acceptance. If the indebtedness of the drawer is not destroyed, the bank assumes the position of making a direct advance. Exception to this statement might be made only in case the payee permitted the renewal of the acceptance. It is not surprising, therefore, to find in the Bulletin for February, $1916,{ }^{x}$ an Informal Ruling to the effect that

the provisions of section 5200 of the United States Revised Statutes would apply to the indebtedness arising between the drawer of the bill and the accepting bank in case the drawer fails to furnish funds with which to meet the acceptance.

A somewhat confusing situation might arise, however, in the case of the rediscount of an acceptance which had been purchased previously by the accepting bank. By the act of rediscount, which transfers the paper to another institution, the bank ceases to occupy the position of a lender of money. After rediscount its liability is preciscly the same as that which existed before the purchase of the bill. The bank's obligation becomes.contingent only. Section 5200 does not apply. ${ }^{3}$

We may next consider the conditions governing the use of the acceptance for various classes of permitted purposes. Let us first turn our attention to the use of the acceptance in the establishment of the dollar exchange. By the amendment of September 7, i9 6 , member banks

' l'age 6.t.

af. Upinion of Counsel, Bulletin, September 1, 1917, p. $6 x) 6$. 
were empowered, with the special permission of the Federal Reserve Board, to accept drafts

for the purpose of furnishing dollar exchange as required by the usages of trade in the respective countries, dependencies, or insular possessions.

The Federal Reserve Board was given power to determine whether the country's trade usages were such as to necessitate the acceptance of drafts originating therein. In the December I, 19I6, Bulletin, ' we are informed that applications had been granted for the acceptance of drafts drawn in Porto Rico, Santo Domingo, Costa Rica, Peru, Chile, Brazil, Venezucla, Argentina and Bolivia. The Board refused ${ }^{2}$ to include England or France in this list. Thereason for this discrimination was explained asfollows: ${ }^{3}$

The purpose of this Act and the regulation made pursuant thereto was to enable the American banks to provide dollar exchange in countries where the check is not the current means of remittance in payment of foreign debts, but where the three months' bankers' draft is generally used for that purpose. . . .

The Board is informed that the bankers' custom of selling three months' drafts in preference to checks originated in countries where the mail connections were irregular and the foreignexchange market was a limited one, and where it would have been difficult for the drawing banker to be certain that he could find a cover against the checks drawn by him in time to forward it by the same mail, whereas, in drawing a three months' draft, he would feel assured of being able to forward remittances before his obligation fell due.

In other words, irregular mail connections make it impossible frequently to depend upon the immediate remittance of "cover." In such cases, a time bill is desired, giving sufficient opportunity for remitlance.

$\therefore$ Page 665.

2 Ibid., p. 666.

3 Ibid., pp. $665,666$. 
In a ruling by the Board ${ }^{x}$ it appears that attempts have been made to draw such bills when the usages of trade were not such as to require them. In some countries where the dollar was at a premium such drafts would be drawn to supply the needed exchange. The Board ruled that these drafts could not be accepted by American banks. It appears, therefore, that "the usages of trade" refers solely to the customs created because of the lack of regular mail connections.

Statutory limitations upon the ability of banks to accept such drafts were as follows: In no case could the amount of acceptances exceed one half the capital and surplus of the accepting bank. Ten per cent of the capital and surplus would be the maximum unless "the draft or bill of exchange is accompanied by documents conveying or securing title or by some other adequate security."

The second class of bankers' acceptances were those arising out of the importation or exportation of goods. In absence of special permission from the Board, nember banks are given the right to accept to an amount equal to fifty per cent of their capital and surplus. The Board is empowered, however, to grant permission to applying banks to accept up to one hundred per cent of the capital and surplus. In pursuance of this power the Board has regularly published the names of banks which are to be permitted to accept the larger amount.

The reason for the insertion of such restrictions in the statute is not difficult to explain. The acceptance is a means whereby the accepting bank aids its customer to secure funds from the outside banking community. Clearly no one bank should be permitted to (lraw too heavily upon other banks for the benefit of its own customers. Stating the limitation in terms of a maximum and a mini-

'Bulletin, August, 1920, p. 835 . 
mum gives the Board some discretion regarding the sort of banks which are to be granted in greatest degree tho acceptance privilege. In order to ensure the aceeptance against misuse, the Board has been unwilling to encourage its employment on the part of firms whose standing is not of the highest.

During the foreign-trade boom following the armistice, assertions were made frequently that these limitations were too severe. It may well be that, in the course of time, a further amendment to the statute will be necessary. But in this period the volume of foreign trade was extraordinarily great. Under more normal conditions the need of the acceptance should not prove so great. It may be preferable, furthermore, to extend its use among a larger number of banks before granting greater powers to any one.

As in the case of the domestic acceptance, member banks may accept drafts which arise in foreign trade having a maturity of six months. The maturity of a draft, rediscounted by a reserve bank, however, must not exceed three months. It cannot be granted under an agreement to renew. ${ }^{\mathbf{x}}$ The purpose of the acceptance was merely to finance transactions capable of being liquidated in a comparatively brief period. Funds, desired for longer purposes, should be obtained by means of a straight loan. Since a direct loan would be subject to the restrictions of section 5200, Revised Statutes, agreement to renew an acceptance would offer virtually a means of evading the terms of the statute.

This should not be interpreted, however, as denying a member bank the privilege of granting an acceptance credit outrunning six months. The acceptance credit may be considered merely as permission to draw the drafts. The limitation applies to the maturity of the drafts, not to the

${ }^{\prime}$ Cr. Opinion of Counsel, Bulletin, March, 1920, pp. 777-78. 
length of the period during which such drafts may be draivn.

A problem of some difficulty had to do with the means of identifying a foreign-trade transaction. How could it be distinguished from an operation of domestic tracle? In case the dealer handled only goods in foreign trade, the presumption would be clearly in favor of classifying it as a foreign-trade acceptance. But if the party handled goods for the domestic as well as for the foreign trade, it would be more difficult to determine to which class it belonged. In the latter case, accordingly, it has been ruled that the dealer could be required to display a contract for foreign sale. It would not be necessary, however, to identify in the export trade the specific goods placed on board ship. ${ }^{x}$

In the early days of reserve operation it was easy to understand the necessity of distinguishing between foreign and domestic-trade acceptances. Then, acceptances could be given only to finance transactions arising out of the importation or exportation of goods. But later amendments permitted domestic acceptances under conditions substantially similar to foreign. In what, then, consists the value of this distinction to-day? The answer consists in part of the provision that whereas member banks may be permitted to accept both classes of bilfs up to an amount equal to one hundred per cent of their capital and surplus, "acceptances growing out of domestic transactions shall in no event exceed fifty per cent of such capital stock and surplus." To determine whether any one bank is exceeding its acceptance powers, it is necessary to learn how large are its acceptances for donestic and how large for foreign-trade financing.

The provisions of the original act relating to foreinntrade transactions were drawn in rather general terms. It

${ }^{2}$ Cf. Informal Ruling, Bulletin, Decemler I, 1915, pp. +05-u6. 
was merely stated that the transaction must involve the importation or exportation of goods. Would it be sufficient, then, if the ultimate object of the transaction was to supply goods for export?

The Opinion of Counsel in this matter is stated in the Bulletin for September I, I9I5. 'To quote the terms of the inquiry stated therein:

A domestic corporation, which for convenience will be designated "Company A," enters into a contract with another domestic corporation, designated "Company B," to furnish material to be used by Company $B$ in the manufacture of products which Company $B$ is under contract with a foreign purchaser to export. Query: Can a national bank accept a draft or bill of exchange drawn by Company A and accompanied by the necessary documents?

It is obvious that to hold such an operation "foreign trade" would be to widen enormously the permitted classes of acceptance transactions. Many domestic transactions result finally in a foreign sale. Many of them frequently would be difficult to trace. It is not surprising, therefore, that Counsel ruled that the transaction itself must involve a foreign sale or purchase. It is not enough that the domestic transaction be mercly related to the foreign.

Let us now turn out attention to domestic acceptances. The first class of these acceptances permitted by the statute are those growing out of domestic shipments of goods secured by the attachment of shipping documents conveying title to the goods. In this respect such domestic acceptances stand on a different basis from the foreigntrade acceptance. In the case of the latter the provisions of the statute were intended merely to ensure the fact that there had been a shipment. Congress evidently intended,

sage 276 。 
however, to restrict domestic acceptances to a greater extent, because it provided that the shipping documents must convey to the accepting bank title to the goods. Such goods can be released to the purchaser, however, on the execution of a deed of trust stipulating that the proceeds from the sale shall first be devoted to the cancellation of the acceptance credit. ${ }^{\text {I }}$ The release of the security would cause, however, the limitations of section 5200 to apply. In that case the bank is secured neither by the attached documents nor by the actual security of the goods. ${ }^{2}$

The.more strict limitations upon domestic acceptances were due to the possibilities of greater abuses. The volume of domestic transactions is much greater than that of foreign. Greater possibilities of evil attach, therefore, to the domestic acceptance.

The duration of these acceptances may be as great as six months. But in no case may they run for a period longer than necessary to finance the sale. ${ }^{3}$

An interesting question arises as to the power to accept when a corporation is making a shipment of goods to its own agent. Such a transfer could not be consiclered as a sale. It would not seem legitimate to permit a clraft to be accepted for any other purpose than to finance the shipment, to offset temporarily the cost of transporting the goods. In this case the maturity of the draft should approximate the duration of their transit. ${ }^{4}$

The principal concern of the Board has thus been to confine the use of this type of the bank acceptance to the financing of the shipment or the sale of the goods. Funds desired to enable the goods to be carried through the process of manufacture into finished products should not

Cf. supra, pp. I80-18I.

a C. Informal Ruling, Bulletin, March, I92 I, P. 308.

3 Ibid., p. 308.

${ }_{4}$ Cf. Informal Ruling, Bulletin, September I, I917, p. 690. 
be financed by the acceptance. The acceptance should not be employed to secure working capital. Funds for such uses should be obtained by the discount of the borrower's promissory note. The acceptance contemplates the extinction of the credit from the proceeds of the groods obtained by the sale of the acceptance.

The second class of permitted domestic acceptances was those secured at the time of the acceptance by warehouse receipts conveying title to readily marketable goods. The function of this acceptance is to assist the producer in the orderly marketing of farm crops. If funcls could not be obtained freely to hold the products of the farm in the locality of their production for a reasonably quick sale, the producer would be more largely dependent upon the offer of outside capital. The producer can well argue that means should be found to place him on the same basis as the outside purchaser with reference to his ability to obtain banking capital. Banking capital may be scarce in the growing section. Since the security must be that of "readily marketable staples" only, the risk of the bank which grants the acceptance credit should not be great ordinarily.

Such methods as these could be abused easily if no limit were placed on the period for which the funds thus obtained could be employed. By a permanent advance of funds the bank might be supplying capital for commodity speculation. Legitimate use of the acceptance for this purpose was thus stated by Counsel of the Board as follows: The purpose must be

to carry goods covered by warehouse receipt pending a reasonably immediate shipment, a reasonably immediate sale, or a reasonably immediate distribution into the process of manufacture. ${ }^{\mathrm{I}}$

×Cf. Opinion of Counsel, Bulletin, January I, 1920, p. 67. 
The acceptance must not be made subject to renewals." The security may be cattle provided the maturity is no longer than that required to fatten and resell. ${ }^{2}$

The use made of this type of the acceptance must depend upon the definition of "readily marketable staples." "In the Bulletin for July, $1919{ }^{3}$ the Board stated:

A readily marketable staple may be defined as an article of commerce, agriculture, or industry of such uses as to make it the subject of constant dealings in ready markets with such frequent quotations of prices as to make (a) the price "easily and definitely ascertainable and (b) the staple itself easy to realize upon by sale at any time.

This definition would bar the use of the acceptance for the great majority of manufactured articles. Acceptances secured by warehouse receipts to automobiles and automobile tires were held by the Board in the January, I920, Bulletin ${ }^{4}$ to be unwarranted. This class of acceptances may be considered, therefore, as devised in largest measure to meet the special marketing needs of the agricultural borrower.

The restrictions thus far mentioned relate to the power of member banks to accept. It is necessary next to learn the conditions governing the power of reserve banks to acquire acceptances.

Under its discount powers, reserve banks can acquire acceptances maturing within three months from date of discount. Six-months acceptances must be held, therefore, for a period of three months before they become cligible for discount with a rescrve bank. Until May, I92I, the acceptance was treated as a commercial bill, and

'Bulletin, March, 1920, p. 277.

${ }^{2} \mathrm{Cf}$. Informal Ruling, Bulletin, July, 1921, p. 315.

3 Page 652.

4 Page 65. 
subject, therefore, to the statutory limitations applicable to such paper. But in that month foreign trade conditions were interpreted to be such as to warrant an extension of maturities. Accordingly, in the desire to encourage the granting of acceptances of longer maturity by member banks, an exception was made by a ruling of the Board whereby acceptancesgrowing out of transactions involving the importation or exportation of goods might be eligible for purchase by reserve banks even though the maturity at the time of purchase was as great as six months. ${ }^{x}$ A further reason for this regulation was to widen the acceptance market by adapting acceptances to the requirements of savings banks. Foreign-trade acceptances might be desired by these institutions if the reserve banks had power to protect the market by acquiring acceptances of longer maturities. By extending the maturities of bills eligible for purchase the protecting power of reserve banks would be enlarged. ${ }^{2}$

Bankers' acceptances rediscounted under the terms of section I3 must be endorsed by a member bank. Openmarket purchases under section I4 need not be endorsed. Nevertheless, the policy of the Board has been to take all feasible steps to ensure the worth of paper thus acquired. Accordingly, by Section B, Series of $192 \mathrm{I}$, it was held that an unendorsed acceptance "is not eligible for purchase until the acceptor has furnished a satisfactory statement of its financial condition," and agrees to submit any information concerning the underlying transaction requested by the Federal Reserve bank.

An endorsement by the accepting bank adds little, however, to the strength of the acceptance. Accordingly, the Board has not welcomed purchases directly from the

See infra., pp. I9I-192.

'Cf. Bulletin, June I, I92I, p. 648. 
accepting bank. It prefers that the acceptance should be acquired from another bank. It was only because of the weak market for acceptances in some districts that purchase directly from the accepting institution has becn condoned. But in February, 1920, reserve banks were instructed to make all such purchases at the rate applicable to commercial paper rather than at the preferential rate applicable to bankers' acceptances. ${ }^{\mathrm{I}}$

Open market purchases under section I4 are not subject to the requirements of section 13 , that the paper accuired by reserve banks shall not bear the name of a borrower indebted to the member bank to an amount exceeding ten per cent of the bank's capital and surplus. Nevertheless, as a matter of banking policy the Board announced that it desired member banks to recognize this restriction as applicable to open-market purchases. Discretion in this matter, however, is left to the district banks.

The preceding discussion relates exclusively to the acceptance powers of member and reserve banks. By a series of amendments to section 25 of the act, member banks have been endowed gradually with powers to invest in the stock of corporations possessing certain acceptance privileges. Let us turn our attention next to this matter of syndicate acceptance development.

Section 25 of the original act gave national banking associations, with a capital and surplus of more than \$I,OOO,OOO, power to establish branches in forcign countries for the "furtherance of the foreign commerce of the United States, and to act, if required to do so, as fiscal agents of the United States." In the discussion preceling the passage of the act on December 23, 1913, the public had been rather thoroughly educated regarding the necessity of such foreign branches. In the matter of for-

¿Cf. Bulletin, Junc, 1921, p. 699 . 
cign trade some forcign agency must act as the forcign correspondent of the Ancrican bank in such matters as the making of collections on export bills, honoring and issuing letters of credit, supplying credit information for the benefit of American industry. Foreign banks, under the control of, and devoted primarily to the welfare of, foreign industry could not be expected to perform all. these services with strict secrecy and impartiality. It was a matter of frequent comment that American trade secrets found frequent disclosure through the medium of foreign banks. It is not strange, therefore, that our legislators decided to equip certain types of our banks with powers more in accordance with those possessed by their foreign banking competitors.

Under the terms of this section many foreign branches were established. It soon appeared, however, that the act did not go quite far enough. Banks which were not desirous themselves of establishing these foreign branches insisted that they should be permitted to coöperate with other banks in the organization of foreign banking institutions. Accordingly, the amendment of September 7, I9I6, contained a provision permitting certain types of banks to subscribe to stock in institutions "chartered or incorporated under the laws of the United States or of any State thereof, and principally engaged in international or foreign banking."

The work of institutions of this sort must be largely of a commercial nature. Their advances must be, in large measure, short-time advances. In the period following the signing of the armistice, however, it became clear that the industrial needs of Europe were such as to demand the granting of credits running for a relatively long period of time. By a further amendment to section 25, signed by the President on September I7, 1919, national banks were 
empowered to assist in the formation of institutions to provide investment as well as commercial credit. Curporations to be formed under the authority of this legrislation must be "principally engaged in such phases of international or foreign financial operations as may be necessary to facilitate the export of goods."

But while stock might be subscribed in such institutions, no means were provided for the Federal incorporation of foreign banking corporations. By further amendment to section 25, which became law on Decenber 24, I9I9, the so-called Edge Act, this difficulty was eliminated.

At the time of the passage of the Edge Act its purpose was generally proclaimed to be the assisting of Europe in the reconstruction programme. In the April, I920, Bulle$t_{i n}{ }^{\mathbf{x}}$ however, we are informed that it should not be regarded as merely of temporary importance. Its permanent endeavor was to provide for the establishment of felerally incorporated institutions with sufficient power to compete on even terms with forcign institutions. In Europe institutions of the type of the "investment trust" had long since been developed to encourage foreign trade and foreign investment. The basic purpose of these institutions is to substitute for the investor domestic for foreign securities. To obtain capital from its investing public its own debentures are offered. These debentures should be safer than those possible of individual selection. The investments of the company are much more widely diversified than an individual's of limited means possibly can $l x$. They are superintended by an offecial with special (1pportunities to investigate the worth of foreign securitics purchased. The investment trust, furthermore, can conduct its operations on a scale impossible for that of the individual. Its capital is collected from a number of savers.

3 Pages $379-82$. 
Finally, the purchaser of the debentures could be fortified by the knowledge that shrinkage of earnings would be borne first by the company's shareholders, and that not until the losses wipe out the capital and surplus is his own equity disturbed. Corporations organized in this country under the Edge Act would possess power to purchase sccurities in companies conducting a business engaged in forcign trade.

Corporations formed under this act may operate either on a debenture or on an acceptance basis. In view of the fact that the framers of the legislation undoubtedly had in mind an institution of the type of the foreign "investment trust," it may seem difficult to account for its acceptance powers. It might appear that the issuance of debentures alone would suffice. It must be remembered, however, that the purpose of these corporations was to supply for foreign-trade purposes short- as well as long-term credit. In the matter of short-term acceptance credits, member banks felt the limitations on the aggregate permitted by section 13 rather severe. The Edge Act offers a means of lessening this difficulty.

Under the terms of the law the acceptance of bills and drafts was to be subject to any limitations and restrictions the Federal Reserve Board might impose. By Regulation $\mathrm{K}$, Series of $\mathrm{I} 92 \mathrm{O}$, the Board has permitted corporations which issue no debentures to make acceptances for the purpose of supplying dollar exchange and for the purpose of furthering the importation or exportation of goods Bills accepted of the first class may run for three months; those for the last class six months. For one drawer acceptances cannot exceed ten per cent of the capital and surplus "unless the transaction be secured or represents an exportation or importation of commodities and is guaranteed by a bank or banker of undoubted solvency." Limitations 
upon the aggregate volume of acceptances were to be governed by the following regulations:

Whenever the aggregate of acceptances outstanding at any time (a) exceeds the amount of the subscribed capital and surplus, 50 per cent of all the acceptances in excess of the amount shall be fully secured; or (b) exceeds twice the amount of the subscribed capital and surplus, all the acceptances outstanding in excess of such amount shall be fully secured. The Corporation shall elect whichever requirement (a) or (b) calls for the smaller amount of secured acceptances.

Dollar exchange acceptances are not permitted to exceed fifty per cent of the banks' subscribed capital and surplus.

Although the liability of the bank is only contingent in the case of a draft drawn under an acceptance credit, it seemed desirable to ensure a sufficiency of liquid assets against these acceptances. Accordingly, certain reserve provisions were inserted in the Regulations.

Banks of this country displayed no immediate haste to take advantage of this authority to form such corporations. In the early part of 192 I announcement was made of the formation of the Foreign Trade Financing Corporation under the sponsorship of the American Bankers' Association. The capital of this corporation was to be $\$ 100,000,000$. At that time there were only two other Edge Act corporations in existence. These possessed capital stock of $\$ 7,000,000$ and $\$ 2,100,000$ respectively.

Much difference of opinion exists regarding the future of such institutions. Lack of sudken growth may be explained in part by the inevitable friction and delay in securing the large amount of capital such institutions would repuire. The depreciation of the dollar value of foreign currencies also rendered it uncertain to make antvances to foreign traders. The development of some such

- See keport of the Federal Reserve l3oard for 1y20, p. 26. 
plan of supplying international credits as the Ter Meulen may lessen the future need of Edge Act institutions. It has been anticipated, however, that the Ter Meulen bond would be issued to importers in foreign countries largely for the purposes of enabling them to obtain raw materials. The supplying of eapital for such purposes as the purchase of machinery may establish a place for the Edge Act corporations.

Full development of any institution of this sort must wait, however, in large measure upon the rectification of certain unsound financial practices employed at the present by European countries. As long as these countries refuse to balance their budgets and continue to meet deficits by new creations of currency, as long as credits are employed for non-reproductive purposes, as long as currency inflation continues, relief to Europe will be difficult. But these corporations have another purpose than aiding in the reconstruction of Europe. A leading motive was to develop machinery whereby American financial institutions may be unhampered in meeting the legitimate requirements of foreign trade.

As a concluding inquiry let us turn to the policy of the reserve banks in the endeavor to encourage the use of the acceptance. For the years I9I5, I9I6, and a part of I9I7, the discount rate on bankers' acceptances varied from two to four per cent. The Board sanctioned the application of minimum and maximum figures in order to permit reserve banks to differentiate according to their own discretion between paper of various degrees of solvency. In this early period the market for acceptances was largely that established by the reserve banks. The paper was new, and special discount corporations had not been formed to such an extent as to offer an immediate market for this paper. Accordingly, it was made possible for a very low rate to be applicel. 
There is no doubt but that the reserve authorities were genuinely eager to encourage the use of this type of paper. Aside from any considerations thus far noted, acceptances would be expected to evoke a more intense foreign demand than that for any other grade of paper. With such a foreign market created, it was hoped that it would be possible to shift the purchase from London to New York by alternate changes in discount rates.

During 1917 , however, the rates hardened. By the end of the year they had risen to 3 to $4 \mathrm{I} / 2$ per cent, except for three reserve banks where the rates were 3 to 5 per cent. The latter part of the year open-market charges on bankers' acceptances maturing within 3 months were 4 per cent as a minimum. This was slightly less than the rates on 6I-90-day paper secured by United States war obligations (4 I/4 per cent). Relatively the same figures were maintained during the year 1918 .

This lessening of the rate advantage given to the acceptance may be explained on several grounds. First,

It was thought that a lower rate for any class of paper than that borne by member banks' 15 -day collateral notes secured by Government obligations might have an unfavorable effect upon the Treasury's operations. ${ }^{\mathrm{x}}$

In other words, it was not desired to do anything which might interfere with the sale or the market for war securities. Secondly, sufficiently good progress had been achieved in the acceptance movement to render less necessary an extremely low preferential rate. The increase in the open-market purchases by Federal Reserve banks is indicated by the following figures: ${ }^{2}$

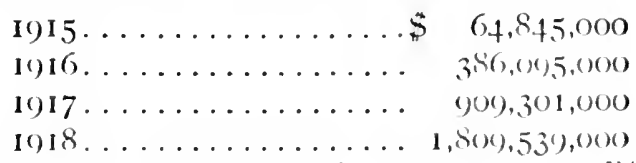

"Report of the licderal Reserve Board for 1918, (1) 19. "Ibid. 
Finally, money-market conditions during i9 8 were such as to render it unnecessary to endeavor to meet the lower British rate. Free shipments of gold were suspended and connection between the two markets was destroyed. The higher rate exacted here did not mean the driving of financing to London because of the disturbances wrought in foreign trade and finance.

Since I9I 8 the policy of the reserve administration has been to establish a greater similarity for the different classes of paper of corresponding maturities. On December 2 I, I 92 I, the average rates charged on bankers' acceptances maturing within three months was the same as the commercial paper rate. Figures showing the purchases by reserve banks from I9I 7 to I 920 were as follows: ${ }^{x}$

ACCEPTANCES BOUGHT IN OPEN MARKET BY RESERVE BANKS

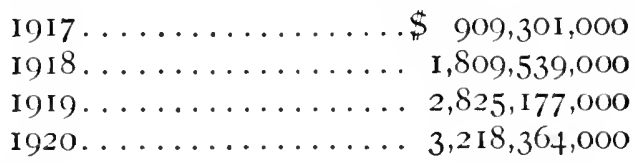

The holdings of reserve banks of bankers' acceptances on certain dates of 1920 and 192 I were as follows: ${ }^{2}$

END OF

September, r920. . . . \$ \$306,295,000

December, $1920 \ldots \ldots \ldots 276,096,000$

March, I92 I.......... I32, I06,000

June, $1921 \ldots \ldots \ldots \ldots \ldots 48,586,000$

September, $1921 \ldots \ldots \ldots$ 45,761,000

These figures show a decided falling off in the acceptance activities of reserve banks during the year I92 I. A similar decline is indicated by available figures bearing on member bank acceptance activities. Through inquiries sent out by the American Acceptance Council it was ascertained, in

seport of the Federal Reserve Board, I920, p. 52.

'Bulietill, November, 1921, p. 1269. 
417 answers out of 482 inquiries, that bankers' acceptances outstanding on April I, I920, amounted to as much as $\$ 799,000,000$. By April I, I92 I, this figure liad shrunk to $\$ 644,000,000$. Investigation of the Federal Reserve Board indicates an approximately similar decline for the same period. $^{\mathbf{r}}$

Many factors serve to account for the decline in acceptances in possession of reserve banks in $192 \mathrm{I}$. The lessening volume of foreign trade and the fact that the preferential rate enjoyed by the acceptance has been virtually eliminated have retarded both the necessity and the desire of member banks to finance in this way. The general easing of the money market has enabled many banks, which would depend otherwise upon the acceptance, to finance their clients by the straight loan. At the same time, the improvement in the money market has enabled many banks to hold in their own portfolios acceptances purchased, until maturity. On the part of foreign branch banks there has been an increased competition with the reserve banks in the purchase of this paper. This latter fact would not concern, however, the operations of member banks.

Despite these facts long-time prospects for the acceptance development appear favorable. In some States, such as New York and Massachusetts, recent legislation permits savings-bank acquirement of acceptances. The Board's ruling in May, 1921, lengthening the maturity of eligible acceptances to six months, should render this paper more desirable for savings banks. As the period of depression gives way to activity, more and more situations will arise in which customers' requirements will be too heavy to be met by direct advances. Elucation and propaganda, moreover, may accomplish muclı, and a

'Bulletin, July, 1921, pp. 775-76. 
great deal of work still remains for some reserve banks in lending their facilities to member banks in the purchase of acceptance paper.

The future development of the acceptance market is highly necessary. Otherwise, surplus funds of member banks will again be entrusted in large volume to the callmoney market. The call-money market is not under the direct control of the reserve system. Stock cxchange paper is not cligible for rediscount or purchase. 


\section{CHAPTER IX}

\section{THE OPEN-MARKET OPERATIONS OF RESERVE BANKS}

In the mind of the public much confusion has existed regarding the difference between the open-market and discount operations of the reserve banks. The first class of operations are authorized by section I 4 of the act, and the latter class by section I3. But in what way can a distinction be made between the character of the work which can be performed under the authority of these two sections?

A widely accepted belief has been that in the open-market operations the reserve banks deal directly with the public; whereas by their discount powers they operate only with the member banks. Color is lent to this view by noting certain facts about the early legislative history of the act. The report by Chairman Glass for the House Banking and Currency Committee on September 9, 1913, contained the following statement:

It [the committee] recommends that these bankers' banks shall be given a definite capital, and that they shall do business only with the banks aforesaid, and with the Government.

The later inclusion of section I4 in the act is interpreted, therefore, as the extension to reserve banks of powers to deal directly with the public. However this may be, section It of the final bill authorized reserve banks to "purchase and sell in the open market, . . . either from or to domestic or foreign banks," " certain specified classes of paper.

- House Report, 6zd Congress, Ist Session, pp. 16 et seq.

Italics are the writer's. 
Under the terms of this section reserve banks may deal with banks. All that can be said for this point of view, therefore, is that the open-market powers are the sole authorization for direct dealings with individuals and corporations. Such powers are not granted by section I3. Section I4 also permits a reserve bank to deal with other than its own member banks. It may buy or sell certain types of securities and commercial paper from or to member banks in other districts. It cannot rediscount under section I 3 for the member banks of other districts.

Neither can complete distinction be found by noting whether there has been endorsement by the member bank of the paper offered the reserve bank. It is true that rediscounted paper must be endorsed by member banks, whereas the statute does not require paper purchased under the authority of section if to be endorsed. Nevertheless, the Board has endeavored by its regulations to encourage the practice of giving precedence to endorsed paper in the reserve banks' open-market purchases.

Nor can conclusive distinction be had by noting the types of paper which may be acquired under the authority of the two sections. It is true that certain types of Government securities and municipal warrants may be purchased under section $\mathbf{I} 4$ only, and that promissory notes can be aequired by reserve banks only by a discount authorized by section $\mathrm{I} 3$. The original bill permitted the open-market purchase of "notes, drafts, and bills of exchange." But in the final draft the words "notes" and "drafts" were stricken out of section I4, although they are retained in section $\mathbf{I} 3$. But even after these alterations bankers' acceptances and bills of exchange could be dealt in by the authority granted by either section. Classification of securities and paper in the two sections overlaps.

In the case of bank acceptances, however, nearly all the 
paper acquired from member banks has been in accordance with the authority granted by section $\mathrm{I} 4$. This is due to the fact that the rate on prine acceptances bought in the open market has been lower than the rediscount rate for commercial or agricultural paper. The principal exception to this statement relates to bankers' acceptances unendorsed by a bank or banker other than the acceptor. In this latter case the higher rate on rediscounted paper applies.

If the paper is authorized by both sections and is acquired from a member bank, section I4 must be regarded, therefore, as conferring additional powers by which reserve banks may deal with member banks. As stated previously, however, the open-market regulations have been such as to discourage the applications of member banks involving paper not of the highest degree of liquidity.

In view of the fact that the House Committee in its report of September 9, I9I3, recommended that the bankers' banks must confine their dealings to member banks and the Government, it is peculiarly interesting to inquire into the motives which led to the inclusion of the open-market section in the final bill. It was understood, of course, how desirable such powers would be in cnabling reserve banks to make profitable investment of their surplus funds. On occasions when the volume of rediscounting falls off, the earnings of rescrve banks would diminish unless they could be permitted to go out in the open market and find invest. ment use for their funds. This consideration woukd hold for any central banking system. But the structure of the Federal Reserve was such as to render it peculiarly necessary that the district banks possess these powers. Member banks were compelled to subscribe to the stock of the reserve banks. Their interest and enthusiasm in the new system must pall unless a reasonable dividend is 
received on stock subscriptions. At least, it is not desirable that reserve banks operate at a clirect loss.

Open-market operations, noreover, represent under some situations the only effective means whereby reserve banks can take aggressive action in the control of the money market. There can be no rediscounting unless the member banks take the initiative by making applications to the reserve banks. On occasions when member banks' reserves are plentiful, increase in rediscount rates may result in no correction of member banks' practices in advancing credits frecly. Member banks may then ignore the advice and warnings of the reserve administration. Accordingly, if the reserve banks are to be more than a mere set of emergency institutions, they should be given power to effect general money-market conditions by their purchases or by their sales. Such measures are especially necessary in the endeavor to realize, first, more uniform rates throughout the country; and, second, to control the Nation's gold movements in such a way as to avoid excessive outflow at one period followed by enormous inflow in another. Direct sale and purchases are needed to accomplish the first result when banks in other districts are not attracted by the higher rates in the capital-poor sections. As a matter of fact, there have always been many obstacles in the way of the free flow of bank funds to the district of high rates. Rediscounting alone may not affect the situation markedly. In the matter of controlling gold movements, a principal past difficulty has been the inability of our many exchange-dealing banks to adopt a unified policy regarding alterations in our discount rates as it appeared necessary to attract or to repel gold. No institution, furthermore, was charged with the responsibility of accumulating the supply of foreign credits which could be drawn upon in lieu of gold shipments in time of a declining exchange. 
Finally, it was anticipated that some of the open-market powers would prove very helpful in encouraging the use of dollar credits. If forcign countries are to be induced to employ dollar exchange as a means of international payment, they must be satisfied that a ready market will exist in this country for the discount of the bills which their bankers and merchants draw. When the domestic market fails for prime bills of this sort, the reserve banks must protect it by their purchases. In opposite fashion, the institution responsible for the control of the Nation's gold movements should be given power to establish credits abroad which may be drawn upon in times when the balance of payment is unfavorable. Such drawings may make unnecessary shipments of gold. Accordingly, certain specified types of operations are permitted by section 14 in order to accomplish this purpose.

One aspect of this question is of peculiar importance in the establishment of the dollar exchange. This is the matter of quoting forward discount rates. As stated by Paul M. Warburg before the Pan-American Financial Conference: ${ }^{1}$

A bank in a foreign country, when buying a dollar acceptance, must be assured of the rate at which the bill will be discounted when it reaches our country. On this rate it will largely depend whether the foreign shipper will use his European or his American credit facilities. The Federal Reserve banks are fully alive to the importance of this question, and I may state on behalf of some of the largest of these banks that they will be prepared to give the greatest possible assistance by adopting a liberal policy in quoting such forward rates, good for a certain clate or for delivery upon the arrival of mail by a given steamer.

It seemed clear to the framers of the act that paper permissible for open-market dealings must be highly

Quoted from Bulletin, July I, 1915, PP. 132-36. 
liquid. Purchases at one season or year become sales at another. Control of the market involves sales quite as much as purchases. It was insisted, therefore, that reserve banks should not buy large amounts of paper or securities which would not command a broad market in the periorl when it is desired to unload.

It may seem strange, therefore, to note the inclusion in section I4 of certain classes of investment paper. Throughout the act, the underlying theory appears to be that short-time paper growing out of commercial transactions is preferable to investment paper as an item in reserve banks' portfolios. It might seem as if investment paper would have been excluded in section 14 quite as throughly as in section 13. But there was the desire to make the Federal Reserve system of especial service to the Federal Government and the local subdivisions. Accordingly, by section $\mathrm{I} 4$, permission is given for investment in certain specified classes of Government securities. As a matter of fact, similar powers are granted by section 13. Therein eligible paper is made to include that drawn for the purpose of carrying or trading in bonds and notes of the Government of the United States. On purely financial grounds it might have been argued that Government securities frequently rise in price in time of extensive liquidation. The fear attaching to private securities in period of liquidation seems often to increase the demand for Governments. These securities possess a more stable market than the general mass of obligations issued by private corporations.

Paper purchasable under section 44 falls into four classes. We may mention first the Governments. Section $14 \mathrm{~b}$ states that reserve banks may

buy and sell, at home or abroad, bonds and notes of the United States, and bills, notes, revenue bonds, and warrants with a maturity from date of purchase of not exceeding six months, 
issued in anticipation of the collection of taxes or in anticipation of the receipt of assured revenues by any State, comty, district, political subdivision, or muniripality in the continental United States, including irrigation, drainage and reclamation districts, ...

Two facts in this sentence deserve emphasis. In the first place, municipal warrants must be issued solely in anticipation of later receipts. Fears as to the wisdom of including them may be mollified somewhat on this account. In the second place, irrigation and reclamation districts are included in the class of governmental subdivisions whose issues are purchasable under the authority of this section. There appears to be no attempt here to discriminate against agriculture or land-development.

A second class of open-market paper consists of bills of exchange and bankers' acceptances. Need for these powers has been explained in previous chapters. The bankers' acceptance is peculiarly necessary for foreign-trade financing and it was believed that its rapid development necessitated the sponsorship of central banking authority.

An interesting question relates to the period within which purchasable bankers' acceptances must mature. This section empowers reserve banks to purchase and sell, in the open market,

cable transfers and bankers' acceptances and bills of exchange of the kinds and maturities by this Act made eligible for rediscount, . . .

Since discounted paper, by the terms of section I3, must be payable within three months, it might appear as if purchasable bankers' acceptances must have no longer maturity. If this be true, it would be puzzling to understand the legal authority for the Board's Regulation B, as amended in May, 1921, wherein reserve banks are author- 
ized to purchase bankers' acceptances arising out of foreign-trade transactions and having maturities as extended as six months.

In reply to the writer's query on this matter the Board stated its position as follows: ${ }^{2}$

The question of whether the Board's regulation authorizing the purchase of six-months' acceptances is in conflict with the terms of the Federal Reserve Act depends upon whether or not the phrase "of the kinds and maturities by this act made eligible for rediscount" refers both to bankers' acceptances and to bills of exchange or refers only to bills of exchange. It cannot, of course, refer to cable transfers, because cable transfers are not eligible for rediscount under any circumstances. The phrase might, however, qualify both bankers' acceptances and bills of exchange or might qualify only bills of exchange. The Federal Reserve Board has always interpreted it as applying only to bills of exchange, and in its regulations of the Series of 1915 , 1916, I917, and 1920, it has authorized the purchase in the open market by Federal reserve banks of acceptances growing out of the domestic storage of goods, although the only acceptances eligible for rediscount as growing out of domestic storage transactions are those growing out of the storage of readily marketable staples. The term "goods" is, of course, more inclusive than the term, "readily marketable staples." Consequently, the Board's Regulation B, Series of I92I, making eligible for purchase in the open market, subject to certain conditions, acceptances with maturities not in excess of six months which grow out of foreign transactions, was not predicated upon any new interpretation of the law.

Looking only at the language of this particular provision of the Federal Reserve Act, it is not clear whether the phrase "of the kinds and maturities by this act made eligible for rediscount" qualifies both bankers' acceptances and bills of exchange or qualifies only bills of exchange, but as heretofore indicated the latter interpretation now has the sanction of established usage, and this would, I think, have great weight with any

Sce supra, p. 174 .

2 In a letter to the writer. 
court which had to pass upon the question. Furthermore, the legislative history of the Federal Reserve Act inclicates that the Board's interpretation of the provision is the correct one. The corresponding paragraph of the bill as first passed the House of Representatives provided "That any Federal reserve bank may, under rules and regulations prescribed by the Federal Reserve Board, purchase and sell in the open market,... prime bankers' bills, and bills of exchange of the kinds and maturities made eligible for rediscount, and cable transfers." The words "and bills of exchange of the kinds and maturities by this act made eligible for rediscount" thus constituted one separate and complete clause with a comma at the beginning and at the end, and it is quite clear that the term "prime bankers' bills" was not intended to be qualified by the words "of the kinds and maturities by this Act made eligible for rediscount." There is nothing to indicate that the subsequent amendment which the Senate made in the phraseology of the provision was intended to give any broader application to the phrase "Of the kinds and maturities by this Act made eligible for rediscount," and the fact that the provision as thus amended is at least ambiguous is indicative of the absence of such intent.

The last class of permitted open-market powers relates to dealings in cable transfers and golel coin and bullion. Section I 4 states that reserve banks shall have power

to deal in gold coin and bullion at home or abroad, to make loans thereon, exchange Federal reserve notes for gold, gold coin or gold certificates, and to contract for loans of gold coin or bullion, giving therefor, when necessary, acceptable security, etc., etc.

These powers were conceived to be necessary in order to enable the reserve banks to exercise some control over the exchange market and to protect the dollar exchange. By acquiring forcign credits or accumulating gokd holdings abroad the reserve banks may be able to provicle American industry with the means of foreign payment on such 
occasions as might otherwise result in a depreciation in the dollar or an excessive outflow of gold.

The reserve system went into operation in a period marked by much confusion and uncertainty. In the haste to secure the functioning of the system it was not deemed essential that provision be made at the outset for the complete exercise of its open-market functions. Accordingly,

the Board determined to confine itself in the beginning to those matters which were deemed absolutely essential to setting the banks in motion upon a basis of reasonable efficiency. It was felt that the regulations relating to discount operations and commercial paper in general were fundamental and they should be prepared and issued at once. ${ }^{\mathrm{t}}$

Nevertheless, on December I8, I9I4, authority was given for the purchase of Government bonds. Shortly afterwards, December 23, regulations were sent out relating to the purchase of warrants and municipal bonds. Early in I9I5 regulations were issued relating to bankers' acceptances, and by a

letter of October 8 , confirmed by a circular and regulation of December 6, the Board authorized the several institutions to purchase, at rates to be fixed by them within certain limits prescribed by the Federal Reserve Board, all those classes of bills of exchange which are by the Act made eligible for rediscount.

Several points in these circulars deserve mention. The first relates to the purchase of acceptances. By Circular I9 of November 29, I9I5, reserve banks were authorized to purchase domestic as well as foreign-trade acceptances. Since the act permitted national banks to accept only to finance transactions arising out of the importation or cxportation of goods, the question may arise as to the

× Report of the Federal Reserve Board, 19I4, pp. 8-9. 
source of domestic-trade acceptances. The answer is that since the enactment of the Feleral Reserve Act a number of States had adopted legislation permitting the domestic acceptance, and these were marle eligible by the Board for purchase by the reserve banks. 'This action foretold the later adrocacy by the Board of an amendment to the act permitting national banks to accept for domestictrade purposes. If such action was not anticipated, the Board probably would not have made State bank domestic acceptances purchasable by reserve banks. It was also advocated in this circular that reserve banks should give preference

to acceptances endorsed by a member bank, discounted under section 13, not only because of the additional protection that such endorsement affords but also because of the reason that acceptances discounted under section 13 may be used as collateral security for the issue of Federal Reserve notes. ${ }^{\mathrm{I}}$

Particularly because of the disturbed conditions abroad, the Board advocated caution in foreign-exchange dealings. While the Board did not insist that foreign bills of exchange should be accepted before purchase, it did rule that unaccepted bills either should be secured by documents or bear a satisfactory endorsement other than that of the acceptor or drawer.

After the issuance of these circulars reserve banks were authorized to exercise to the full extent permitted the powers conferred by section I4. In view of the fact that the open-market section evidences more clearly than any other the intention of the framers that the reserve banks should operate continuously and not merely during emergencies, it is especially necessary to note the use which has been marle of these powers. The following figures enable

\footnotetext{
2 Circular No. 20. By amemlments to the original act acoeptances purchatised under section if may be used as collateral security for liederal kieserve nutes.
} 
comparisons to be made between the volume of the discount and open-market operations by years from I9I5 to I920:

\begin{tabular}{|c|c|c|c|c|c|c|}
\hline & 1 & 2 & 3 & 4 & 5 & 6 \\
\hline YEAR & $\begin{array}{c}\text { TOTAL BILLS } \\
\text { DISCOUNTED } \\
\text { FOR MEMBER } \\
\text { BANKS }\end{array}$ & $\begin{array}{l}\text { ACCEPTANCES } \\
\text { BOUGHT IN } \\
\text { THEOPEN } \\
\text { MARKET' }\end{array}$ & $\begin{array}{c}\text { UNITED } \\
\text { STAIES SECUR- } \\
\text { ITIES AND } \\
\text { MUNICIPAL } \\
\text { WARRANTS }\end{array}$ & $\begin{array}{c}\text { TOTAL } \\
\text { INVESTMENT } \\
\text { OPERATIONS }\end{array}$ & $\begin{array}{l}\text { PER } \\
\text { CEN I } \\
\text { OF } \\
1 \text { TO } 4\end{array}$ & $\begin{array}{l}\text { PER } \\
\text { CENT } \\
\text { OF OPEN } \\
\text { MARKET } \\
\text { TO } 4\end{array}$ \\
\hline $\begin{array}{l}1915 \ldots \\
1916 \ldots \\
1917 \ldots \\
1918 \ldots \\
1919 \ldots \\
1920 \ldots\end{array}$ & $\begin{array}{r}\$ 161,353,000 \\
207,870,500 \\
9,014,186,454 \\
39,752,933,847 \\
79,173,969,730 \\
85,320,874,000\end{array}$ & \begin{tabular}{|r}
$\$ 64,845,000$ \\
$386,095,000$ \\
$1,077,712,509$ \\
$1,809,538,795$ \\
$2,825,177,002$ \\
$3,218,364,000$
\end{tabular} & $\mid \begin{array}{c}81,572,770 \\
147,436,180 \\
105,421,882 \\
5,852,05 \times, 075 \\
4,737,920,421 \\
7,988,310,0003\end{array}$ & $\begin{array}{r}307,770,800 \\
7+11,401,610 \\
10,197,320,845 \\
47,414,530,717 \\
86,737,067,153 \\
96,527,548,000\end{array}$ & $\begin{array}{l}52.4 \\
28.3 \\
88.3 \\
83.7 \\
91.3 \\
88.3\end{array}$ & $\begin{array}{r}47.6 \\
71.7 \\
11.7 \\
16.3 \\
8.7 \\
11.7\end{array}$ \\
\hline
\end{tabular}

I The first purchase of bankers' acceptances was made February 15, 1915. 2 Includes only $\$ 1000$ of municipal warrants.

3 No purchases of municipal warrants.

In the early years of operation, I9I5 and I9I6, the openmarket operations were relatively very important. There was then little demand for discounts, and reserve banks were forced to make open-market purchases in order to find even moderate employment for their funds. In these years the reserve ratios of the reserve banks were very large. But after the outbreak of the European War the discounts requested by member banks were so great that open-market purchases declined in comparison. In aggregate volume, however, they increased year by year without interruption. In every year from I9I5 to I920 the total volume of openmarket purchases exceeded that of the previous year.

One of the most interesting objections to the open-market provisions of the Reserve Act was voiced by Miss Anna Youngman in the September, I92I, number of the American Economic Review. She argued that it was a mistake to endeavor to discriminate against the promissory note in reserve banks' purchase operations. Our trade credit system is based upon the note and not upon the bill of

$\therefore$ Pages $463-85$. The Efficacy of Changes in Discount Rates of Federal Reserves bianks. 
exchange, and attempts to foster the use of the bank acceptance do not appear to her to have been exceptionally successful. She calls attention to the decline in the volume of bankers' acceptances in $192 \mathrm{I}$, and alludes to the fact that this decline would have been all the more startling were it not for the large volume of acceptance credits covering sugar and those granted for the creation of dollar exchange. Bankers' acceptances appear to her of principal value in foreign-trade transactions. Accordingly, the present openmarket policy of the reserve banks is characterized as an attempt to secure effective control of the market by confining dealings to a paper arising in a small and relatively unimportant class of transactions. She advocates that reserve banks' open-market powers should be extended to include notes as well as bills growing out of commercial transactions. It also seemed plausible to her that, to a limited extent, reserve banks should be permitted to purchase, as well as discount, paper representing loans on stock exchange collateral.

Miss Youngman's objection to great dependence upon the barkers' acceptance is also based upon her belief that the market for this paper is highly uncertain. There is the competitive English demand for bankers' acceptanees, and the English rate must be met if the financing is to be done in the New York market. As long as acceptances grow largely out of international transactions, reserve banks must come to the rescue of dealers when the English rate is lowered, even though such action is contrary to our own investment neels. Open-market transactions in commercial paper should be based more largely upon domestic paper.

Her argument for extending reserve bank operations to stock exchange paper is based upon the be lief that all money rates should be subject to influence, if not to control, by the reserve banks. Unless call rates can be intluenced by 
reserve activities, rates on other loans are also difficult to influence. To a certain degree banks have their choice in sclecting the market which offers highest compensation. The reserve banks should be in a position to break abnormally high rates by direct lending. If they cannot do so, their rediscount policy may be rendered futile.

The reader's reaction to these somewhat revolutionary views will depend largely upon the degree of control he is willing to repose at the present time in the reserve administration. Granted that the reserve banks can be managed impartially, with economic foresight, without fear of political hostility, the argument is entirely in favor of widening the classes of open-market paper. The greater the variety of paper which can be dealt in, the more complete the power of the reserve administration. Possibilities of evil are also greater. The reserve banks are governed by men, not by automatons. They have, or ought to have, personal interests to protect in the stock and investment market. No matter how great the endeavor to keep primarily in mind the needs of the public, personal responsibilities would tend always to create an unconscious bias. Aloofness from the stock exchange loan market is not an ideal situation, but it is perhaps the price that must be paid to limit plutocratic domination.

On purely political grounds, Miss Youngman's programme is unworkable. Even at the present time, when direct advances on stock exchange security are impossible, there is a widespread belief that security speculation has benefited more largely than commerce or agriculture from the use of the reserve system's funds. The insistence upon an agricultural representative upon the Federal Reserve Board is one indication of this widespread belief. How much greater must have been the discontent with the reserve management if direct purchase of security paper 
had been permitted? The writer is convinced that the unpopularity of a system possessing such powers would have caused a complete remodeling of the system, possibly to the detriment of all classes, in the agricultural depression of 1920 and I92I. Political considerations are quite as important as financial. The present system is better than the old; too much should not be expected of the reserve banks until the elementary principles of finance are more widely understood. Development cannot be too rapid. It is more desirable that slowly but soundly foundations be built for the more imposing edifice of the future.

In regard to the inclusion of the note arising from commercial transactions the writer will agree that too much attention may have been reposed in the bankers' acceptance. But the trade acceptance arising from domestic operations is eligible for purchase. In the past the popularization of the trade acceptance has encountered many obstacles. But part of the difficulties are due to the insistence that its progress should be sound rather than merely rapid. It might be better at the present time to admit the promissory note to open-market dealings. But many dangers would lie in such a course, and it appears the part of wisdom to postpone discussion of the admission of the note until the trade acceptance has had a more conplete trial. Many will hold, furthermore, that the abuses of the open book-account system are sufficient to warrant some lessening of the reserve banks' powers.

Miss Youngman's proposals are basel largely upon her doubts as to the efficacy of changes in rediscount rates to affect general money charges. In many localities high loan rates will persist despite any lowering of reserve banks' rates. In such localities banking competition may be absent and the high charges represent some degree of monopolistic extortion. The only means of breaking such 
rates lies in permitting reserve banks to step in as competitors of local banks by their direct purchases. But such action could be made effective only by permitting dealings in the type of paper customarily employed. Since the trade acceptance is unfitted for the needs of many buyers, it is argued that reserve banks should be permitted to purchase notes.

Final conclusion upon this point must wait upon the discussion of the relation of reserve banks' rediscount rates to those exacted in the general market. ${ }^{x}$ But it will be generally agreed, perhaps, that as a matter of public policy the present is not the time to introduce the reserve banks in the rôle of more active competitors of member banks. Present clamor directed against the reserve system is sufficiently great without adding this new source of discontent.

During the World War a situation arose which led Senator Robert L. Owen, then Chairman of the Senate Banking and Currency Committee, to propose the establishment of a separate reserve bank in order to relieve the other reserve banks of a portion of their responsibilities under section 14 of the act. ${ }^{2}$ This proposed new Federal Reserve bank was to be charged with the responsibility of preventing the dollar exchange from depreciating abroad and with furnishing American commerce with the credits required in foreign transactions. If the plan which he advocated had been enacted into law, the regional character of our reserve system would have been altered to that extent. His bill proposed that in the field of international credits one new reserve bank should serve for all American industry and not primarily for any one district.

The cause of Senator Owen's investigations was the

See infra, pp. 339, 340.

' Cf. H. L. Reed, "Senator Owen's Proposal to Stabilize Foreign Exchange Rates," American Economic Review, September, 1918, pp. 66I-69. 
falling of the dollar below its normal gold par in some of the neutral countries of Europe, particularly Spain, Norway, Denmark, Netherlands, and Sweden. This depreciation occurred in spite of the fact that during the years 1916 and I9I 7 the United States possessed a favorable trade balance with each of these countries as well as with the world at large. But credit extended by the United States to its European allies resulted in a plethora of dollar credits possessed by merchants in these countries. When purchases were made from Spain by England, or France, payment was frequently made by drawing upon these dollar credits. Possessing a favorable trade balance with the world as a whole, Spain acquired more dollar credits than needed to balance its own requirements. Since shipments of gold were suspended, the dollar shrank in terms of pesetas.

In many ways this depreciation of the dollar was unwelcome. As a matter of first importance, perhaps, it was argued that it rendered somewhat more difficult the campaign to assert the superiority of dollar credit as a medium of international payments. The supremacy of sterling exchange in the past was due in no small measure to its stability in terms of gold. Here was the opportunity to establish the dollar as the one class of exchange which had not depreciated in the general financial confusion engendered by the World War. Nevertheless, for the reason given, the dollar declined in terms of the currencies of some of the countries with which the balance of trade was in our favor.

The discount on the dollar abroad also increased the cost to our merchants who had remittances to make for their imports. A premium on the peseta of twenty-five per cent meant that, instead of the dollar buying five pesctas, it bought only four. But aside from any direct material loss the psychological effect of a falling dollar was held not to 
be good. In normal situations a falling exchange points toward future gold withdrawals. The dollar exchange has fallen in most of our financial crises. Its depreciation during the World War could be pointed to by our enemies as evidence of our financial instability.

Attempts on the part of private bankers to remedy this difficulty had been productive of little benefit. Private negotiations for the necessary loans in Spain had failed. Accordingly, Senator Owen proposed that the reserve banks should grapple with this problem. But as they were then constituted they lacked the machinery and powers necessary to secure effective results. No single one of the reserve banks was specified by the statute as responsible for the maintenance of the parity of the American dollar, and it would be impolitic to delegate this responsibility to any one. Charges of sectional discrimination would inevitably arise. It was asserted, furthermore, that each reserve bank was already so completely occupied with matters of domestic finance that it could not give the problem of supplying foreign trade with the credits it required the necessary attention.

Senator Owen proposed, accordingly, that

the Federal Reserve Act be so amended as to provide for the establishment of a Federal Reserve foreign bank. ${ }^{x}$

This bank would assume the responsibility of furnishing American Commerce with a stable exchange. It would have power to establish foreign branches generously equipped with power to acquire and sell foreign credits. If necessary these credits could be established in foreign countries by the sale of Government bonds. No individual

I See remarks of Hon. Robert L. Owen on Senate Bill 3928 to establish the Federal Reserve Foreign Bank, etc., in the Senate of the United States, February 25, 1918. Cong. Rec., pp. 2817-825. 
or bank other than this foreign bank would have the legal right to

sell dollar balances at less than gold par, except as payment for merchandise imported into the United States, without the express authority of the Federal Reserve Board. ${ }^{\mathrm{x}}$

It would be directed by a board of nine men appointed by the President of the United States, and all of these would be merchants and not bankers. Bankers would be excluded from the directorate, for

Our American bankers have not sufficiently realized that banking grows with commerce . . the banker who thinks in terms of interest and commission and profit exaction is not happily constituted to determine the best methods of serving commerce.

This would explain why reliance could not be placed on the recently established foreign branches of private banks. The proposed bank would be a reserve bank. ${ }^{2}$

This proposal met with some opposition from such men as Mr. Harding, and Mr. Warburg. Mr. Harding, for instance, ${ }^{3}$ felt that the situation was not sufficiently serious to justify the setting up of such elaborate machinery as was called for by Owen's plan. He did not feel that the temporary dislocation of exchange with a few European neutrals would interfere with the campaign to encourage the use of the dollar exchange. The Orient and South America would not be affected directly by the discount on the dollar in these European nations, and it was in the Orient and South America that the best opportunity existed for encouraging the use of the dollar exchange. The continent of Europe would probably readopt earlier methods.

Cong. Rec., pp. 2817-825.

2 Ibid.

Bulletin, August I, I9I8, p. 72 ff. 
The rather sudden termination of hostilities, bringing with it the elimination of the dollar discount, seemed in the minds of most financiers to render Owen's machinery unnecessary. If the plan had been adopted, however, it would have marked the first departure from the regional idea. The writer ventures to remark that, if the regional plan is to be altered in the future, the opening wedge may prove to be some modification of the open-market powers. It is in the employment of these powers that the reserve banks can exercise their greatest initiative in the attempt to control money-market conditions. 


\section{CHAPTER $\mathrm{X}$}

\section{ADVANCES OF RESERVE BANKS - NOTE ISSUES}

THE commercial bank creates credit or credit money of two forms, note issues and deposits. Although to-day both in Great Britain and the United States the deposits exceed note issues in volume and importance, early banking in both countries was primarily a matter of issuing notes. It is correct in the main to state that modern English banking found the germ of its development in the evolution of the bank note. The goldsmith's receipt of the fifteenth and sixteenth centuries, supposedly representing a value in coin or bullion equivalent to its face, gradually was adapted to the requirements of a circulating medium. In the course of time it was made payable to bearer and did not require endorsement when transferred to another party. It came to be made out in round even sums instead of to the amount representing the deposit of the owner. When accepted by the public, even though issued to an amount exceeding its security, the trick of modern commercial banking had been learned.

The issuance of circulating promises to pay exceeding the value of the coin or bullion security subjects the economic world to many dangers. Excessive issues of bank paper currency may produce the same results as the undue issue of Government paper money. The price level may advance rapidly to new heights, the gold of the country may be driven out as a consequence of the adverse trade balance engendered by the excessive issues, and if 
non-redeemable an important element in the currency may depreciate. For these reasons attempts to restrict its issues would be expected. It might be argued, however, that unregulated deposits could create the same undesired results. However this may be, note issues were developed before deposits, and the early dangers of uncontrolled banking were attributed largely to note issues. Accordingly, in English and American banking law, we find greater restrictions imposed upon banks in their note-issue powers than in their powers to create book credits subject to check.

It may be that the discrimination against the note rests upon a sound economic basis. The note is payable to bearer and possesses a greater circulation power than the bank check. It may circulate for a considerable period far from the place of its issue. It may get in to the pocket of an individual who has no opportunity to learn of the solvency of the issuing bank. Because of its tendency to stay in circulation longer, the ability of the bank which issued it to redeem is not so speedily tested as in the case of the bank deposit. Since a check is not adapted for continuous circulation, a bank is automatically restrained from issuing too large a volume of deposit credits. So large an amount of checks drawn against it may be presented to the clearing house by other banks that a deficit in cash arises. But if the issue is a note, some time may elapse before the issuing bank is called upon to make redemption. The penalty may not be visited so speedily.

At any rate, either because of these considerations or because of precedents established in the era of state banking, or because of the historical fact that early banking abuses were largely note-issue abuses, the framers of the National Banking Act enacted the most rigid note-issue regulations. As finally amended the law rendered it impossible for national banks to issue notes to an amount 
exceeding the par or market value of Government bonds, whichever is the lowest, deposited with the Treasury to secure them. Basing note issues on the public debt made their inelasticity inevitable. Their volume tended to fluctuate more in accordance with the state of the bond market than with the needs of trade. Consequently plans of banking reform prior to the panic of 1907 usually took the direction of basing note issues more largely upon a wider class of bank assets. Commercial paper, in general, was to be the security instead of Government bonds. And while the Aldrich-Vreeland Act evidenced the influence of the opponents of an asset currency, provision was made for the issue of notes in periods of emergencies collateraled by a wider range of securities.

Had bank note issues continued to occupy their old position of prominence the need of a more elastic bank note currency would have been uncontrovertible. But since the date of the writing of the National Bank Act the use of bank deposits has become relatively much more important. At the present time it is estimated that the check is employed as a means of payment in from eightyfive to ninety per cent of our total transactions. If deposit credits under the national banking system had possessed a large measure of elasticity, it would have been logical to attribute our currency ills primarily to the bank note. But, largely because of our rigid reserve requirements, deposits also were insufficiently elastic. The case for an asset currency was not quite so clear as it otherwise would have been.

These facts may be crudely illustrated by noting the customary train of events in past periols preceling general collapse. As reserve ratios fall, banks become more and more hesitant to advance needed credits. The demand for loans becomes all the more intense as the market begins to 
decline. By the time general public confidence is disturbed, runs upon banks may ensue. Since these runs represent a demand for currency, the inability of banks to expand their bank note issues freely appears to constitute the principal weakness of the banking system. But would the public demand for cash have arisen if at an earlier period banks had been permitted to expand their grants of deposit credits in the necessary amount?

There are many occasions when the demand upon a particular set of banks is primarily a demand for a circulating medium. In the autumnal season of harvesting strain, crop-moving expenses could not be met by expanding deposits alone. Checks given to transient laborers, for instance, would be presented speedily to the banks for encashment. An enlargement of the volume of bank currency appeared the necessary requirement. But if reserves against deposits had been less rigid, the difficulties created by the currency demands would not have been so intense. The currency would have been supplied at the expense of reserve money, but the penalty of slightly impaired reserves would not have been so great.

By the time the Federal Reserve Act was written, however, these facts were more widely accepted. In the mind of the writer the principal point of progress marked by the Federal Reserve over previous plans is the greater recognition of the need of elasticity of deposits. A thorough-going reform plan could not confine itself to an attempt to secure merely an asset currency.

It was agreed nevertheless, that the ideal plan of reform would secure elasticity in bank note issues as well as in deposits. Bank note currency provides a means of supplying the public with a circulating medium without impairing a bank's supply of reserve money. Elastic bank note issues are part of the problem of securing more flexible deposit credits. 
These matters of elementary banking principle granted, the problem of banking reform became that of determining what set of banks should possess the bank note issue responsibility. Should bank notes continue to be issued by the member banks or should their issue be concentrated in the hands of reserve banks only? Bearing in mind the fact that the reform movement was in part an attempt to secure greater concentration in credit control, it is not surprising to note the decision to concentrate the new bank note issuing powers in the hands of the reserve banks. The idea of centralized control was joined to that of greater elasticity in the media of exchange.

It has been pointed out frequently that bank note issues are not absolutely essential to central bank operation. If its power to control credit be sufficient, the central bank may meet the demands upon it by accumulating in ordinary times a surplus supply of reserve money to provide for seasonal or emergency needs. It is probably true, however, that public confidence in a system without bank note issue powers would not be so great. Possessing such powers it appears as if the central bank's ability to manufacture the necessary media of exchange is incapable of exhaustion. As indicated previously, moreover, the general public has come to attach an exaggerated importance to bank note issues.

But what should be done with the old bond-secured issues of national banks? There was much to offer against any programme of eliminating or subordinating these issues. They constituted a definite part of our money supply approximating $\$ 75^{0}, 000,000$ and could not be withdrawn immediately without subjecting the country to a money famine. Furthermore, banks had purchased the bonds not so much for their investment yield as for the security of their bank note issues. This artifically created 
demand caused the price of the bonds to move to a higher point than warranted by their income return. Because of the circulation privilege attaching to its bonds, the United States has been able to borrow money at cheaper rates than almost any other country in the world. In the pre-war period, while the United States two per cents, bearing the circulation privilege, were selling at about par, British two and a half per cent consols were selling only slightly above seventy, and French three per cent rentes at about eightyfive. Justice demanded that the Government take no action confiscating bond values bought in good faith.

In order to reconcile the legitimate interests of the banks with the requirements of commerce for a more elastic currency a means was provided by the act for the gradual purchase from the national banks of a portion of their bonds by the Federal Reserve banks. By the terms of section 18 any member bank desiring to retire any of its circulating notes is permitted to "file with the Treasurer of the United States an application to sell for its account, at par and accrued interest, United States bonds securing circulation to be retired." Such applications can be made in the twenty-year period, December, 1915, to December, 1935. At the end of every quarterly period the Treasurer of the United States is required to furnish the Federal Reserve Board with a list of such applications. The Board may require the reserve banks to purchase these bonds, which are then to be apportioned among the twelve reserve banks pro rata according to their relative capital and surplus. It was provided that the reserve banks could not be compelled to purchase more than $\$ 25,000$,000 of these bonds in any one year, and that this amount must include whatever amount of bonds the reserve banks may have purchased directly from the public without the intervention of the Federal Reserve Board. 
In this manner provision was made for the eventual acquirement by the reserve banks of bonds bearing the circulation privilege and the gradual retirement of the bank notes outstanding against them. The reserve banks were authorized to utilize these bonds in one of two ways. First, they may deposit them with the Treasurer of the United States and upon this security issue bank notes to the par value of the bonds. The law stated that such

notes shall be the obligations of the Federal reserve bank procuring the same, and shall be in form prescribed by the Secretary of the Treasury, and to the same tenor and effect as national-bank notes now provided by law.

In case, however, no vital need exists for this currency, the bonds may be converted into one-year gold notes or three per cent thirty-year old bonds not possessing the circulation privilege. Such an exchange is to be made on the basis of par and accrued interest. If this method is availed of, the bond-secured bank notes may be reduced gradually in volume. But this reduction may be very slow, since reserve banks cannot be required to purchase more than $\$ 25,000,000$ of these bonds in any one year. But at any rate provision was made for a reduction relative to the volume of other currencies. As the country grows in population and resources and the other elements in the circulation increase, the bond-secured bank notes will decline in importance.

The extent to which the reserve banks have availed of these provisions in order to issue their own bond-secured currency is indicated for certain selected dates by the following figures:

\section{Federal Reserve Bank Notes in Circulation}

\section{Amount Outstanding}

January 4, 1918 . \$ 8,000,000 December 31, 1919 \$273,450,800 June $28,1918 \ldots \quad 10,390,000 \quad$ December $31,1920 \quad 249,467,000$ December 27, 1918 117,122,000 November 1, 1921 123,296,960 
Without further information it might appear as if the reduction in national bank circulation, particularly in the years 1918 and 1919, must have been exceedingly heavy. This would seem to follow from the fact that the reserve bank notes were required to be secured by Government bonds, and that the surrender of these bonds to the reserve banks must compel a reduction in national bank currency. ${ }^{\mathrm{x}}$ But the figures show no such reduction in national bank circulation. At the close of I92I it was approximately the same as in 1914 and had increased somewhat since 1917. Thus:

Total Volume of National Bank Notes Circulating in the United States
July I, 1917 . . \$715;420,010
January I, 1919.. \$723,532,210
January I I9I 8 719,212,630
July 1, I91 $8 \ldots 724,205,485$
January I, 1920. . $724,338,692$
November I, $1921 \quad 743,288,847$

Clearly the increase in the volume of Federal Reserve bank notes was not at the expense of the aggregate circulation of national bank notes. To what, then, can the increased circulation of reserve bank notes be attributed?

During the World War the attention of Congress was drawn to the uses which might be made of the stock of silverdollars reposing in the Treasury of the United States. Several Oriental countries were accumulating balances against the United States and our allies and it was not desired to meet these claims by exporting gold. So far as silver could be used economically for this purpose, it would seem that the Treasury's stock should be drawn upon. For years this stock had been lying idle as the metallic backing for the silver certificates.

Accordingly, by the Pittman Act of April 23, 1918, the Secretary of the Treasury was authorized to melt down

\footnotetext{
'Unless offset by the purchase of other bonds possessing the circulation privilege.
} 
and sell as bullion not more than $\$ 350$,000,000 standard silver dollars. The bullion could be sold for the following purposes: first, to conserve the Nation's stock of gold; secondly, to facilitate with silver-using countries the settlement of adverse trade balances; thirdly, to provide silver for subsidiary coinage or domestic use. In order to protect the silver market it was provided that the bullion should be sold at a price of not less than \$I per ounce of silver 1000 fine, and that the silver thus withdrawn must be repurchased by the Treasury at the same price. Since the melting down of the silver dollar would destroy the security for the silver certificates, it was provided that these certificates should be retired at the rate of $\$$ I for each dollar melted down or broken up.

This would involve a reduction in one of the elements in our currency. In order to prevent a corresponding contraction in the general circulating medium the Federal Reserve Board was given authority to require reserve banks to issue Federal Reserve bank notes to an amount not exceeding the amount of standard silver dollars thus destroyed. The reserve banks issuing these were required by law to deposit as security United States certificates of indebtedness or one-year United States gold notes.

The amount of Federal Reserve notes thus issued under the terms of the Pittman Act was as follows on certain dates:
UP TO AND
INCLUDING
December 31, 1918........\$1 \$0,803,000
December 31, 1919. . . . . . . 259,375,000
December 31, 1920 . . . . . . . 260,875,000

The Pittman Act was regarded merely as a temporary measure. Section 6 required that, as the silver dollars are recoined through the purchase of silver bullion by the Secretary of the Treasury, Federal Reserve bank notes 
shall be retired in an amount equal to the volume of the dollars so coined. Such purchases of bullion must be made at the rate of $\$ \mathbf{I}$ an ounce. On April I, I92I, ${ }^{1}$ it was announced by the Secretary of the Treasury that the retirement of Pittman Act certificates had been begun and would be continued gradually.

The Pittman Act proved decidedly useful during the war and post-war period. It seems unfortunate, however, that the Treasury was required to repurchase the amount of silver obtained by melting down the dollars. Securing silver certificates by silver coin or bullion is an anomaly in a gold-standard country. The real security for any of our currency, gold, could have been obtained on favorable terms by the final sale of the silver bullion at the highest market silver has commanded in years. We lost our opportunity to work off without great loss our silver, the existence of which had really been a source of embarrassment in previous years. But it may have been politically unwise to estrange the silver interests during the period of hostilities.

But no progress in elasticity was made by the issues of Federal Reserve bank notes. It was by the means of another note creation, the Federal Reserve note, that the endeavor was made by the Act of 1913 to provide the truly elastic element in our currency system. These notes are the issues of reserve banks upon the security of commercial paper, and each note bears the distinctive number of the district in which it is issued.

By the terms of the original act the method of issue was as follows: Any reserve bank could make application to the Federal Reserve Agent-the member of the district directorate who is the official representative of the Federal Reserve Board-for such amount of the notes as it may

:See Bulletin, April, r921, p. 374. 
require. Such applications must be accompanied by a tender of collateral equal to the amount applied for. By the original act the collateral offered in the application must be notes and bills accepted by the reserve bank for rediscount. But the act was later amended in such a way as to include in the collateral paper purchased in the open market. Section 16 now states that

the collateral security thus offered shall be notes, drafts, bills of exchange, or acceptances [acquired] under the provisions of section thirteen of this act, or bills of exchange indorsed by a member bank of any Federal reserve district and purchased under the provisions of section fourteen of this Act, or bankers' acceptances purchased under the provisions of said section fourteen, or gold or gold certificates.

The Federal Reserve Board can at any time call upon the reserve bank for additional security.

These notes were made receivable by all members and reserve banks. They are obligations of the United States and are receivable for all taxes. They are not legal tender for private payments. They may not be counted as a part of the legal reserve of a member bank. Whether or not they may be counted as reserve money by a State bank depends upon law in that State.

The first line of security behind these notes is the commercial paper (gold in lieu of paper) deposited with the Federal Reserve agent. Reserve banks must also maintain a forty per cent gold reserve behind these notes. 'This requirement, however, may be suspended by the Federal Reserve Board. But if the reserve is permitted to fall below forty per cent, a graduated tax paid by the reserve bank will operate as a penalty.

These notes will be issued to member banks through the process of rediscount, and offer a means whereby reserve banks can supply the member banks with counter money 
without depleting their own reserves. Since they are issued through rediscounts, prevention of excessive issues becomes a part of the problem of rediscount policy. Rate increases, more careful scrutiny of the paper offered by member banks, direct refusals, represent the means of preventing unduly large issuance or of compelling their retirement.

But what means were provided to secure their speedy return on occasions when the need has passed? The following devices were included in the Federal Reserve Act. First, the notes of one reserve bank may not be paid out by another reserve bank save by paying as a penalty a ten per cent tax upon the face value of the notes. A member bank however, located within or without the district of issue may pass them out without restriction. Since a Federal Reserve note may circulate for a long time before being deposited with a reserve bank, this provision cannot be expected to do much in the way of compelling their quick redemption. Secondly, the notes may not be counted as a part of the legal reserves of any member bank. A member bank in need of reserve money will be impelled, therefore, to save them for redemption. But on other occasions of ample reserves member banks may not find it necessary to establish their reserves by the rediscount method. In this situation the return of the notes is not likely to be rapid. Finally, the notes are issued only upon the deposit with the reserve agent of commercial paper. If the reserve banks are rediscounting freely, ample paper should be available to replace the collateral upon its maturity. But if the reserve banks refuse or discourage renewals, they may compel member banks to return the notes or their equivalent in other currency.

There is no doubt but that the act provides ample means for redemption in cases where redemption is 
desired. They must be received by any member bank and by any reserve bank; if they reach the counter of another reserve bank, they may be collected either directly from the reserve bank of issue or indirectly through the Gold Settlement Fund at Washington. But while there is an open avenue for rapid redemption, nothing short of a strict rediscount policy is likely to result in their being driven home against the will of the holder. They may get into the vaults of State banks which are permitted to count them as reserve money, they may repose in the tills of merchants or pockets of the people, they may form part of the counter money reserve of member banks. Only one situation is likely to explain their return against the will of the holder, that in which they are acquired by another reserve bank than that which issued them. Expansion of these notes in time of need is easy, but whether or not there is to be contraction in slack season and years depends upon the rigor with which the reserve management exercises its powers of rediscount control.

Mention should be made, however, of a provision in the act which gave the Federal Reserve Board power to exact from the reserve bank an interest charge on all notes issued to the reserve bank not covered by gold or gold certificates in the hands of the agent. The purpose of this provision was to give the Board some power in the way of compelling contraction. Reserve banks compelled to meet such a charge would likely exert, by means of higher rates, pressure upon member banks to return the notes or their equivalent in other money. In case, however, the reserve bank directorate was working in close harmony with the Board, and did not endeavor to thwart the Board's advice to restrict rediscounts, such pressure would not be required. The writer is not aware that a tax of this sort has yet been imposed upon reserve banks. 
In the early period of its existence the volume of rediscounting by reserve banks was exceedingly limited. Nevertheless, a rather large amount of notes got into circulation. Since the notes are issued to member banks through the process of rediscounting, the public was at first somewhat puzzled at the existence of so large an outstanding circulation. On analysis, however, it developed that notes once issued were not being retired upon the maturity of the paper rediscounted. Instead of returning the notes to the agent, the reserve bank would deposit gold as "cover." Reserve banks, when called upon by member banks for currency, would offer the Federal Reserve notes instead of gold. In this way the notes were becoming virtually gold certificates.

A few figures will indicate the extent to which this practice was carried on. On July 2, I9I5, the total amount of notes issued to the reserve banks was $\$ 84,000,000$. As security for these the Federal Reserve agents held lawful money to the amount of $\$ 70,000,000$. On June 30 , I916, the amount of note issues was $\$ 176,000,000 . \$ 165,000,000$ of the cover for this was lawful money. On June 29, 1917, $\$ 402,000,000$ of the security for $\$ 550,000$, 000 of notes was legal tender money. In other words, the accumulation of cash in the hands of the reserve agents was chiefly cash and only to a limited extent paper.

This policy of the Federal Reserve Board was bitterly condemned in certain quarters. The Commercial and Financial Chronicle, for instance, asserted vigorously ${ }^{\mathrm{x}}$ that there was no authority for keeping the notes outstanding in this manner, and that the plain intent of the law was to secure their retirement upon the maturity of their paper collateral. Furthermore, the Board was charged with usurpation of authority. The act did not then

IIssue of August 7, 1915, pp. 398-400. 
permit notes to be issued to reserve banks by the deposit of gold with the agent. But the Board was accomplishing virtually this result by, first, issuing the notes on commercial paper security, and then, upon the maturity of the paper, making gold the cover. In reality, urged the Chron$i c l e$, the Board was breaking the spirit of the law.

Those closely connected with the management of the reserve system did not hesitate sharply to defend this policy. Governor Strong, of the New York Reserve Bank, denied vigorously that the Board was exceeding its authority. ${ }^{x}$ If it had been intended that the notes should represent only paper, a simple provision could have been inserted in the act to that effect. It was clearly the purpose of the act that the notes should become a part of the gencral circulation and the policy of the Board was designed merely to hasten this result. Furthermore, the impounding of gold meant no inflation, but, on the contrary, a restriction of bank credit. For neither by reserve banks nor by member banks could the notes be counted as reserve money.

As the law then stood there can be little question as to the correctness of Governor Strong's views. The deposit of gold cover with the reserve agents did not restrict the possibilities of credit expansion. But the law was subsequently amended in many ways, with the general result of increasing the ability of the reserve and member banks to expand their deposits. The Chronicle was correct in surmising that the practice of impounding gold as cover was a forerunner of many later events the general trend of which was to alter radically the working of the system. In the development of these plans it was incidentally necessary to create a larger field for the circulation of the notes. These subsequent events will be discussed in the follow-

I Issue of August 7, 1915, pp. 412-13. 
ing chapter. They can be treated best in connection with certain amendments altering the reserve requirements for member banks deposits. To-day the Federal Reserve note is the most important element in our general circulation. Its supremacy over other moneys can be noted by examining the following figures: ${ }^{\mathrm{T}}$

Money Held Outside the United States Treasury and tile

Federal Reserve System, November 1, 1921

Gold coin (including bullion) . \$ 373,456,004

Gold certificates.......... I 89, I 41,549

Standard silver dollars...... 38,837,297

Silver certificates......... 21 $2,351,466$

Subsidiary silver........ 259, 176,773

Treasury notes of $1890 \ldots \ldots$ I, ....

United States notes........ 265,4I3,01 8

Federal Reserve notes...... 2,446,481,946

Federal Reserve Bank notes . . 102,363,172

National bank notes....... 719,196,68 I

At the present time the national bank note is dwarfed by the Federal Reserve note. Even though the national bank issues aggregate an amount somewhat comparable to that of I9I4, they have become relatively unimportant. Their place has been seized by the new Federal Reserve note. But whether or not the new note is to be truly elastic, whether or not it is to display the qualities of contractility, is dependent mainly upon the discount policy adopted by the Federal Reserve management.

s Obtained from the Bulletin, December, 1921, p. 1495. 


\section{CHAPTER XI}

\section{ADVANCES OF RESERVE BANKS-DEPOSITS AND RESERVES}

IN the preceding chapter it was remarked that the movement in this country for banking reform took first the direction of attempts to secure an asset currency. The plan formulated by the American Bankers' Association in 1894, known as the Baltimore plan, may be interpreted, for instance, as a direct attack on the bond-security theory. According to this plan it was proposed to permit the issue of bank notes by national banks secured by commercial assets. Protection for the noteholder would consist of : first, the prior lien upon the assets of the failed bank; secondly, restriction of bank note issues to a certain percentage of the capital stock; thirdly, the double liability of stockholders. The plan may be regarded, therefore, as an attempt to ensure the safety of the bank notes by relying upon other requirements than the deposit of Government bonds. But it disregarded totally the problem of securing a more elastic deposit currency.

It may appear as if a similar disregard of the importance of deposit currency was displayed in the Aldrich-Vreeland Act of 1908. It could be asserted, for instance, that the panic of 1907 had demonstrated clearly that the principal difficulty of our banking machinery was the concentration of the reserves of the interior banks in New York City. Because of certain misuses of these funds the deposits could not be withdrawn. After the default of the New York depository banks, substitutes for money, such as 
clearing house loan certificates, had to be clevised. In many localities they were believed to have brought relief. What was accomplished under the Aldrich-Vreeland Act was to make regular provision for the issue of emergency currency under the regulation of the Federal Government. This act did not attempt to go to the root of the difficulty. It contained nothing to prevent future difficulties of a similar sort from again arising. It was purely palliative and not surgical.

But despite its apparent necessity the matter of revising our deposit machinery was a difficult task. It would seem to involve the prohibition of the employment in the financial centers of interior bank deposits for the purpose of supporting stock market loans. Plans which contemplated such restrictions must arouse a great deal of opposition. It was easier to confine efforts to the securing of an asset currency. Such efforts could be made to appear solely in the light of concessions to the banks. They would be given powers which previously were denied. But by the time of the Wilson Administration public opinion had crystallized itself more definitely. The country had begun to understand that any reform which reached the roots of previous difficulties must do something more than merely to provide for emergency note issues. It also must alter old methods relating to the employment of bank reserves.

As a final result of the legislative endeavors culminating in the Federal Reserve Act, four leading provisions were enacted regarding the reserves of member banks. First, it was stipulated that after three years nothing could count as reserve for any member bank except cash in its own vault or deposits with the reserve bank of its district. This did not mean that member banks would be prohibited from keeping deposits with other than the reserve institutions. Banks in the interior could continue to keep deposits with 
big city banks in any amount desired for purposes of domestic exchange and the securing of whatever interest such deposits would command. The only prohibition of the act related to the use which could be made of these deposits. They no longer could be counted as a part of the required legal reserve for the depository banks. ${ }^{\mathrm{I}}$

Secondly, the act reduced considerably the amount of the reserve percentages. The theory accepted was that with reserves massed in central reservoirs the same protection could be furnished the depositor with a smaller amount of reserve money. It was a matter of realizing the economies of reserve concentration. As a result of this reduction it is estimated that in I9I4-I5 an economy of four or five hundred millions of dollars was effected.

Thirdly, it was provided that the transfer of money from private correspondent banks in the central reserve cities to the Federal Reserve banks might be gradual. The law stated that the transfer must be completed within three years after the establishment of the Federal Reserve bank in the district in which the bank was located. A specified amount of the reserve must be transferred to the district reserve bank immediately, another specified portion at the end of the year, and later installments at semiannual intervals.

The purpose of these provisions was to effect the transfer of reserves without subjecting the stock market to a sudden, severe shock. Banks in the central reserve cities were to be permitted gradually to make the necessary rearrangements in their loan position. It was hoped that some progress might be made in establishing the custom of financing sharply fluctuating securities by time instead of by call loans.

Lastly, the act stated a distinction between demand de-

Exception could be made to this statement during the period prior to the completion of the process of transferring reserve money from central reserve cities. 
posits and time deposits. Deposits subject to immediate call necessarily require a larger reserve than those withdrawable only after the expiration of a certain period of time. As to the distinction between demand deposits and time deposits a paragraph of section 19 stated that

Demand deposits within the meaning of this Act shall comprise all deposits payable within thirty days, and time deposits shall comprise all deposits payable after thirty days, and all savings accounts and certificates of deposit which are subject to not less than thirty days' notice before payment.

These reserve requirements for member banks under the original act may be represented by the following scheme:

1. Banks in the Central Reserve Cities (New York, Chicago, St. Louis). I 8 per cent demand deposits and 5 per cent time deposits.

(a) In own vault 6-18.

(b) In reserve banks of its district 7-I 8 .

(c) Balance optional with the bank.

2. Banks in Reserve Cities.

15 per cent demand deposits, 5 per cent time deposits.

3. Country Banks.
After three years $\left\{\begin{array}{l}\text { (a) } 5^{-15} \text { in own vaults. } \\ \text { (b) } 6-15 \text { in reserve bank. }\end{array}\right.$
(c) Balance optional.

12 per cent demand deposits, 5 per cent time deposits.

(a) $4^{-12}$ in own vault.

(b 5-12 in reserve bank.

(c) Balance optional.

Four methods were provided by which deposits could be established with the reserve bank. First, lawful money might be remitted. Secondly, checks or other items might be forwarded for collection to the reserve bank. (In a preceding chapter account has been made of the gradual development of this work. At the present time the reserve banks receive for collection daily an enormous volume of cash items as well as of time items.) Thirdly, commercial paper might be rediscounted according to the terms of sec- 
tion 13. Lastly, certain types of paper or securities specified by section 14 might be sold directly to the reserve bank.

But how far could the reserve banks go in granting member banks book credits? This would depend upon the volume of reserve money possessed by reserve banks. Section I6 states that

Every Federal reserve bank shall maintain reserves in gold or lawful money of not less than thirty-five per centum against its deposits. ...

Since the establishment of the reserve system the minimum reserve percentages for reserve banks have been unchanged. But those for member banks have been altered. Let us next endeavor to find explanation for these alterations.

Although the provisions of the act created a reduction in the aggregate volume of reserves, the new arrangements were not altogether satisfactory to the member banks. Many of their criticisms were unsound; nevertheless, their general effect was to prepare the way for a change. The first criticism was purely the result of a misunderstanding. It involved the belief that member banks would not be permitted to keep deposits in banks other than the district reserve banks. This view was, of course, erroneous. The act prohibited only the counting of such deposits as reserve money.

Secondly, it was asserted frequently that in reality the act increased reserve requirements. Many banks argued that they would be forced for exchange or other purposes to keep deposits with city correspondents as well as with the reserve banks. The two deposits combined might exceed those customarily maintained under the old law.

Reply to this was that since the reserve banks would make collections on checks and other items and credit these 
to the account of the forwarding bank, deposits in other banks for collection purposes would be necessary no longer. In the beginning, however, there was some doubt as to how completely the reserve banks would function in these matters. Would the reserve banks give immediate credit for the remittance of checks drawn against non-member State banks? Would they collect time as well as demand items? Would their service charge be unduly high? These, at first, were matters of doubt. Some time must elapse before reserve banks could demonstrate that in every feasible way they would endeavor to perform the services previously rendered by the correspondent banks of the financial centers.

But even though reserve banks would perform these services, they could not pay interest on deposits. In the past, city banks were willing to make collections, receive at par checks drawn against the bank, as well as pay interest on the balance. The reserve banks would pay no interest.

This objection, however, overlooked the savings effected through the reduction in the amount of the reserve required. Suppose, for instance, that the country bank had outstanding before the establishment of the new system $\$ 100,000$ of demand deposits. The minimum reserve for this would be $\$ 15,000$. Three fifths of this amount, or $\$ 9000$, might be carried as a balance with its city correspondent. The year's interest on this amount at 2 per cent would be \$180. This appeared to be a direct loss.

But under the new arrangement the required reserve would be $\$ 12,000$ instead of $\$ 9000$, or a saving of $\$ 3000$. If this could be invested to realize 6 per cent, the interest would cancel entirely the apparent loss of $\$ 180$.

In the matter of the "float," finally some member banks felt themselves harshly treated. In an early chapter mention was made of the loose practices formerly permitted by the Comptroller according to which country banks could 
establish reserves. Checks drawn against outside banks would be dispatched to the city correspondents and immediately considered as reserve money. Under the clearing plan finally worked out by the Reserve Board, distantly drawn checks would not be credited to the account of the forwarding bank until sufficient time had elapsed in which to make collections. Despite the logic and the necessity of this practice, many banks asserted that they were being harshly treated.

Whether or not these complaints alone would have secured any concessions for member banks cannot be ascertained definitely. But it happened that the plans of the reserve administration were such as to lend its influence to the lowering of reserve minima. The endeavor of the administration was to devise a means of gaining control of a larger portion of the country's gold. The natural method of accomplishing this result would be to require member banks to keep a larger portion of their reserves with reserve banks than that law at first compelled. But it was understood that this could be brought about only by lessening the amount which must be kept in the banks' own vaults. Since it was felt that the concentration of reserve money under the control of reserve banks would be a more economical use of reserve money, the final outcome was a reduction in the aggregate legal minima.

It is easy to understand the importance ascribed by the reserve management to the accomplishment of the purpose of accumulating the Nation's gold more largely in the vaults of reserve banks. Such gold would form the basis for a much larger issue of Federal Reserve notes or of book credits to member banks. The war in Europe resulted in an enormous inflow of gold to America and there was no assurance that after the war there would not be an outflow of similar proportions. In order to guarantee our ability to meet any 
post-war demands, it would be desirable to have it under the control of the Board, which was supposed to keep the general public needs foremost in mind. Then again the disregard of neutral rights had gone so far in the European conflict that it was not at all certain whether the United States could continue to assume an inactive rôle. If war should come, the demands upon our banks would be heavy. A much greater expansion of credits would be possible if the gold was lodged in reserve banks' vaults.

As expressive of the views of one member of the Federal Reserve Board the following remarks may be quoted from an address of Paul M. Warburg: ${ }^{x}$

We are faced with the simple question: Will we be strong enough to share our plenty, during the coming period of stress, with other nations and be the world's banker, or will we be so weak that, when these demands come, we must stop them at once by raising our discount rates high enough to retain our gold at home? Keep all the gold in your vaults, gentlemen, where it is useless for yourselves and deprived of the additional force that it may gain in the hands of the federal reserve banks; keep every cash till in hotels, railroad stations, dry goods stores and what not, filled with gold certificates, and you will rob the country of its legitimate opportunity of growth, of helping itself, and of helping the world. Our foreign competitors will proclaim that only a country willing to part freely with its gold may safely be accepted as a world's banker, and they will point to the fact that in past critical periods, our banks stopped paying in gold. It is our duty to give the world an overwhelming evidence of our ability and determination in the future to maintain our gold obligations under any and all circumstances.

A discussion of the measures employed by the reserve administration to accomplish this purpose forms one of the

¿ Delivered before the American Bankers' Association at Kansas City. See Journal of the American Bankers' Assuciation, October, 19i6, pp. 307-19. Cf. also address by A. C. Miller, another member of the Board, delivered before the Indiana Bankers' Association. Ibid., November, 1916, pp. 385-90. 
most interesting chapters in financial history. At the inception of the new system, it was not clear what machinery could be employed to bring under the Board's control any large amounts of gold. The act required member banks ${ }^{\mathrm{x}}$ to make payments for their capital stock subscriptions in gold. Member banks must also keep a portion of their reserves with reserve banks, but the final transfer of reserves from reserve or central reserve cities would not be completed for three years. These reserves might be established partially, moreover, by rediscounts and not the remittance of specie. Altogether these measures would bring the reserve banks only a small portion of the Nation's gold. Accordingly, the ingenuity of the Board hit upon the previously mentioned device ${ }^{2}$ of impounding gold as cover for note issues. By this means a large quantity of gold was got into the hands of the reserve agents. But this gold was immobile. It must remain as collateral for the Federal Reserve notes, and could not be employed to support further issues of notes or deposit credits extended by reserve banks.

But for the time being the Board was obliged to confine its efforts to the substitution in the general circulation of Federal Reserve notes for gold, and to the accumulation of this gold in the hands of the agents. In this connection it is interesting to read a letter sent by the Board on September II, I9I6, to the various district banks. It had developed that one of the reserve banks had been meeting the currency requirements of its members by shipments of gold certificates. Gold certificates could be obtained a little more cheaply than the Federal Reserve notes. Section I6 states that

The plates and dies to be procured by the Comptroller of the Currency for the printing of such circulating notes shall remain

Section 2.

'See supra, Chapter X, pp. 2I7-219. 
under his control and direction, and the expenses necessarily incurred in executing the laws relating to the procuring of such notes, and all other expenses incidental to their issue and retirement, shall be paid by the Federal reserve banks . . .

The Board, however, requested the reserve banks to ignore their desire to save a small expense and to issue, instead, whenever possible Federal Reserve notes,

thereby helping to concentrate gold certificates in the vaults of the Federal Reserve banks. ${ }^{*}$

But to what extent would member banks be willing to receive Federal Reserve notes? If their need was for reserve money, they could return the notes to the reserve bank and demand redemption. But for counter money purposes the notes would be as good a currency as any. They would be acceptable also by such State banks as were permitted to count them as reserve money.

Nevertheless, there were limits to the willingness of member banks to absorb the notes. They would not be acceptable when held in excess of the amount necessary for till money and when legal reserves were low. Accordingly the Board began to move for changes in the act which would create a wider field for the Federal Reserve note circulation. It proposed an amendment which would permit reserve banks to issue Federal Reserve notes directly against the deposit of gold with the Federal Reserve agents. This suggestion was rejected by Congress together with another proposal that the Federal Reserve notes should be made legal reserve money for member banks. But in the amendments of September 7, I9I6, it was enacted that

Upon the affirmative vote of not less than five of its members the Federal Reserve Board shall have power, from time to time, by general ruling covering all districts alike, to permit member

'Bulletin, October 1, 1916, p. 512. 
banks to carry in the Federal Reserve Banks of their respective districts any portion of their reserves now required by section nineteen of this Act to be held in their own vaults.

The Board ruled immediately (September 8, 1916) ${ }^{x}$ that until further notice

any member bank so desiring shall be permitted to carry in the Federal Reserve Bank of its district any portion of its reserves now required by law to be held in its own vaults.

This amendment did much to increase the willingness of country member banks to transfer their deposits from city reserve agents to reserve banks. It tended also to render the Federal Reserve notes more acceptable. A member bank possessing a sufficient amount of credits on the books of its reserve bank need not worry about the kind of money in its own vaults. For counter-money purposes the notes were as good as gold.

But helpful as this amendment was, its accomplishments were negative so far as rendering any outright advantage to member banks was concerned. Shifting reserves to reserve banks would not increase the member bank's loaning power. If the member bank did not heed the Board's implorations, it would not be subject to penalty. Accordingly, the Board pressed for a change in the law which woukl make compulsory what previously had depended entirely on the discretion of the member bank. Success crowned its efforts by the enactment of the amendment of June 21 , 1917. This amendment stated that thereafter member banks must hok1 their legal reserves entirely on deposit with reserve banks. The only legal reserve would be credits on the books of the reserve banks. Of course the nember bank woukl be obliged to keep on hand a supply of money for payments over the counter. But the amount of this till money would depend upon the discretion of the member bank.

$\therefore$ Bulletin, October 1, 1916, p. 508. 
According to one of the Board's earlier suggestions to Congress, the percentage of till-money reserve would be definitely stated by law. Leaving the matter entircly to the discretion of the member bank, therefore, may be regarded as a step toward the abolishment of the rigid reserve requirements of the carlier days.

There has been a disposition on the part of some banks to insist that this amendment increased rather than decreased the real reserves required of member banks. This argument was based upon the fact that the requirements of the new law made no mention of till money. Whatever amounts must be kept for payments over the counter must be added to the legal requirements. But even with this addition the writer's investigations lead him to believe that for all the banks of the country there was a considerable reduction. At any rate, as will shortly be explained, the ability of reserve banks to rediscount for member banks was increased by this measure enormously. Member banks establish reserves by rediscounting. They were benefited by the terms of this amendment.

The percentage of member banks' net deposits which must be held as credits with the reserve banks has been as follows since the amendment of June 21, 1917.

FOR DEMAND DEPOSITS FOR TIME DEPOSITS

Banks in central reserve cities. .

Banks in reserve cities........

13

Banks in all other cities.......

10

3

In the opinion of the writer this amendment is by far the most important which has been superimposed upon the original act. Occurring shortly after our entrance into the World War, it rendered absolutely certain the ability of our banks, for the time being at least, to guarantee the success of the Treasury's bond sales. It made possible a pyramiding of credits uncxampled in the history of banking. It 
contained great possibilities of good as well as of evil. The expansion of credit which has taken place since 1917 is in large measure due to the working of the amendment of June, I9I7.

Let us now endeavor to explain how efficient gold in the possession of reserve banks has become in furnishing a basis for member banks' deposit credit advances to the business public. First, let us view the situation from the standpoint of the country bank. Taking into account only demand deposits and assuming no till money to be necessary, $\$ 24.50$ of lawful money in the possession of the reserve bank would permit a country bank to extend $\$$ iooo of deposit credits to its clients. The $\$ 24.5$ o would be the 35 per cent reserve for the $\$ 7$ o of book credits granted by the reserve bank to the member bank. This $\$ 70$ would be the member bank's 7 per cent reserve for $\$$ Iooo deposits granted one of its customers. In other words, a dollar of legal tender currency lodged in the vaults of a reserve bank would enable a country bank to loan more than $\$ 40$ of deposit credits.

This same sort of pyramiding of reserves existed under the old national banking system. But then the utmost that could be done was to enable the country bank to loan $\$$ I 3 for a dollar of reserve money lodged in the vaults of a central reserve city bank. The old reserve percentage for country banks was $\$ 1000$. Fifteen per cent of $\$ 1000=$ $\$$ I50. Of this, $\$ 90$ might be held as a deposit with a reserve city bank whose minimum reserve was 25 per cent. Twenty-five per cent of $\$ 90=\$ 22.50$. Half of this $\$ 22.50$, or $\$$ II.25, might be held as a deposit credit on the books of a central reserve city bank which must keep a straight 25 per cent reserve. Twenty-five per cent of $\$$ II.25 is $\$ 2.8 \mathrm{I} ; \$ 60$ plus $\$ 11.25$ plus $\$ 2.81$ is $\$ 74.06 ; \$ 1000$ divided by $\$ 74.06$ is 13 plus. 
Let us now view the situation from the standpoint of the reserve city bank. Under the old system pyramiding of reserves could go to a point where $\$$ IOOO of its deposit could be backed by $\$ 156.25$. The reserve city bank's 25 per cent reserve for $\$ 1000$ is $\$ 250$. Half of this might be kept in the form of a deposit with a central reserve city bank whose reserve must be 25 per cent. Twenty-five per cent of $\$ 125=\$ 31.25 ; \$ 31.25$ plus $\$ 125=\$ 156.25$. In other words, the real reserve minimum was 15.6 per cent.

After the amendment, however, the actual reserve for this class of banks need be only 3.5 per cent; IO/IOO of $\$ 1$ ooo of $35 / 100=\$ 35$. In central reserve city banks a straight 25 per cent reserve was required. Now it need be only 4.55 per cent; $13 / 100$ of $\$ 1000$ of $35 / 100=\$ 45.50$.

Some allowance, however, should be made for the member bank's till-money requirements. Let us assume that a counter-money reserve of 5 per cent would be sufficient, and that this be composed entirely of Federal Reserve notes. Behind these notes the reserve bank must keep a 40 per cent gold reserve. Forty per cent of 5 per cent is 2 per cent. Two per cent, therefore, should be added to the percentages given above.

But, even after making this addition, it will be perceived that a dollar of gold or lawful money in the possession of the reserve bank was rendered extremely efficient in supporting member bank advances. Our reserve mechanism after June, 1921, was very similar to the English system wherein the reserves of private banks consist largely of credits on the books of the Bank of England. But the English custom was the result of a long and slow development. Never before was a currency measure enacted which enabled banks on the moment to multiply so enormously their grants of credit to the business public.

Not only was gold becoming more efficient as reserve 
money, but the inflow of gold to this country prior to the amendment had been enormous. In a few years the net inflow was more than a billion dollars. If this gold could be got into the reservoirs of the reserve system, the power of the new system would be established once for all. Here was an opportunity of centuries and the reserve management did not overlook it. In every possible way the endeavor was made to substitute notes for gold certificates in the general circulation, and to accumulate the gold in the reserve banks' vaults.

One difficulty in accomplishing this purpose resulted from the fact that the Federal Reserve notes could not be issued in sufficiently small denominations. The act limited these issues to denominations of $\$ 5$ and above. It was impossible under these circumstances to keep the notes circulating in as large a volume as otherwise might be accomplished. When the need was for money in small denominations, the Federal Reserve notes would be presented for redemption. The problem was thus to overcome the difficulty created by the large denominations of the notes.

Partial solution for this difficulty, however, was found by an act passed on October 5, I9I 7, which was designed to create a larger field for the circulation of the notes. To quote the Bulletin on this matter: ${ }^{x}$

The passage of the act of October 5,1917 , authorizing national banks to issue not more than $\$ 25$,000 each in denominations of $\$ I$ and $\$ 2$ and authorizing them to issue notes of $\$ 5$ on the same basis as other denominations is intended to provide a larger volume of small bills. The Treasury Department, as is well known, has for some time past been converting large greenbacks or United States notes into notes of small denominations, thereby probably finding a permanent field of circulation for them. As the greenbacks thus move out of the larger and into

${ }^{2}$ Bulletin, November 1, 1917, pp. 833-34. 
the small denominations, an increasing field for Federal Reserve notes is opened. The Treasury, Federal Reserve Board, and the Federal Reserve Banks are consistently coöperating in substituting Federal Reserve notes for the circulation of gold certificates, and they are effectively supported in this undertaking by the national banks and those of the State banks and trust companies which have joined the system.

Various other devices were being employed in the meanwhile to discourage the issuance of gold into the general circulation. By the fall of I9I7 the banking law of New York State had been amended so as to permit State banks and trust companies to count Federal Reserve notes as part of their vault reserves. ${ }^{\mathbf{x}}$ In the securing of such statutes various associations of bankers played an important rôle. April I0, I9I7, the executive committee of the American Bankers' Association at a meeting in New York resolved: ${ }^{2}$

That this committee urgently recommends to the trust companies of the United States that immediate steps be taken to secure amendments, where necessary, to the State laws in order that the trust companies may be permitted to carry their gold reserves on deposit with the Federal Reserve Banks in their several districts, and that as soon as such action can be legally taken, the trust companies offer to deposit these reserves with the Federal Reserve Banks.

In its issue of January 29, 1919, the Chicago Tribune contained an announcement of the position of the Subtreasury of Chicago and the Federal Reserve bank of that city. It was stated that the Federal Reserve notes bear the words:

This note is redeemable in gold, on demand, at the Treasury Department of the United States in the City of Washington, or in gold or lawful money ${ }^{3}$ at any Federal Reserve Bank.

Accordingly, the Subtreasury and the bank were within

${ }^{1} \mathrm{Cf}$. Commercial and Financial Chronicle, August 25, 1917, pp. 760-61.

'See Bulletin, May 1, 1917, p. 335.

3 Italics are the writer's. 
their legal rights in suggesting that the party who wanted gold could go to Washington to get it. They announced that they themselves would not pay out a single gold coin for any purpose whatsoever.

By such methods as these the reserve notes were made to take the place in the general circulation of the legal tenders so that the latter could be available for the reserves of reserve banks. But prior to June 2I, I9I7, the law relating to the collateral securing reserve notes was such as to limit the possibilities of substituting notes for gold. When the collateral originally securing Federal Reserve notes matured, gold would be deposited with the Federal Reserve agent, and the notes would be retained for reissue to the member banks. This gold could not be counted as a part of the reserve for deposits. Accordingly, the effectiveness of the policy of impounding gold as cover for the notes was limited.

This difficulty was lessened, however, by the amendment of June 2I, I9I7, which paved the way for a still greater expansion of bank credits. Prior to this amendment, money deposited with the Federal Reserve agent as cover for the notes could not be counted as part of the reserve for deposits. But after this amendment, gold deposited with the agent as security for the reserve notes could be counted as a part of the reserve bank's 40 per cent gold reserve for notes. This would enable other gold, which previously had been earmarked as the note reserve, to support a larger volume of book credits granted to member banks. The limit was further removed within which note issues might restrict reserve banks' power to create money deposits for member banks.

By such legal and administrative measures the reserve management had answered with finality the question of its future power and influence. The gold hollings of reserve banks became steadily larger, and more and more 
banks became members of the system. The expansive power of our credit structure was increased wonderfully. In later chapters figures will be given regarding the amount of increase in credit advances to member banks rendered possible by these measures. ${ }^{x}$ But enough has been presented to indicate that, as a result of the administrative and legal changes culminating in the amendment of June 2I, 19I7, the working of the reserve system was altered definitely.

One or two matters of banking technique may now be considered briefly. The first relates to the method of computing member banks' reserve percentages. Specifically, what was the law's definition of net deposits to which the reserve percentages applied? To answer this we can do no better than to quote from an Opinion of Counsel in the Law Department in the Bulletin: ${ }^{2}$

Member banks, in determining the amount against which reserves must be carried, may deduct all Government deposits, except postal savings' deposits, ${ }^{3}$ and may deduct from the amount of balances due to other banks the amount of balances due from bank checks drawn on banks located in the same place and exchanges for clearing houses. The law, however, does not permit member banks to deduct checks on other banks located in the same place or exchanges for clearing houses from gross demand deposits, nor does it permit cash on hand to be deducted from gross demand deposits.

In a later chapter certain information will be given regarding the determination of the reserve banks' reserves for deposits granted member banks.

'See infra, Chapter XIV. $\quad$ 'Bulletin, September I, 1917, p. 692.

3 Bulletin, June 1,1917 , p. $45^{8}$. This exemption of Government deposits was the result of an act approved April 24, 1917. While the prime purpose was to assist in financing the war, the law referred to all Government moneys and not merely to the proceeds of bond sales. The purpose was in part to enable the Treasury to keep as long as possible, to the advantage of the local banks, funds in the localities which supplied them. 


\section{CHAPTER XII}

FEDERAL RESERVE DEVELOPMENT, NOVEMBER, 1914, TO DECEMBER, 1916

IN each of the preceding chapters attention has been focused upon some one aspect of Federal Reserve operation. The problems confronting the reserve management cannot be well presented, however, by employing this method alone. It is necessary that we understand the relation of each project to the others in the gradual development of Federal Reserve policy. For this purpose we have divided the life of the reserve system into four periods. The first period, extending from November, I914, to December, 1916, was primarily one of organization-development and preparation for future emergencies. The second period, January, 1917, to May, 1917, is characterized chiefly by two facts. First, the reserve banks by their discount and purchase operations were beginning to secure some degree of effective control over the money market; and, secondly, the reserve system was being made ready to bear the financial strain of the war that began to appear more and more imminent. In the third period, June I, I9I7, to November II, I9I8, the management was absorbed in the task of coöperating with the Treasury in meeting the problems of war finance. The fourth period, extending from the armistice to the spring of 1920 , may be characterized as that of post-war credit and trade expansion. The final period concerns the relation of the reserve system to business and industry in the depression of $1920-21$. 
The Federal Reserve Act became law December 23, 1913. It provided for the appointment of an Organization Committee composed of the Secretary of the Treasury, the Secretary of Agriculture, and the Comptroller of the Currency. Among this committee's duties was the mapping out of the country into the various districts, each to be served by a reserve bank. After this work was completed, the committee served notice upon the national banks of the country to subscribe to the capital stock of the new banks. As soon as a sufficient amount of capital was guaranteed in this way, the formalities were begun of granting corporate life to the reserve banks and proceeding with the election of directors for the district boards. In the mean while the President was engaged in the task of appointing the members of the Federal Reserve Board. In this some delay was encountered. President Wilson had announced that in the selection of the Board he did not wish suggestions of the sort usually offered in the making of appointments. He appeared to be convinced that the selection of a strong personnel was of the utmost importance to the Nation. But after his nominations were made, some further delay was caused by the action of the Senatorial Banking Committee in holding up, on the ground of their business affiliations, the appointments of Mr. Warburg and Mr. Jones. Mr. Warburg refused to submit to cross-examination by the committee. His nomination, however, eventually was confirmed. ${ }^{x}$

In these ways the spring and summer of 19 I 4 slipped by, and it seemed that the opening of the reserve banks for business must be postponed until the spring of 1915 . But in the meanwhile the European conflict broke out, creating such financial disturbances as to cause to be reconsidered the question of the date of operation.

${ }^{2}$ Cf., Comnercial and Financial Chronicle, July II, I9I4, pp. 9I-92. 
The nature of the upset to the Nation's finances created by the sudden outbreak of hostilities is now thoroughly familiar to the general public. In a very brief period European security exchanges were closed and New York became the world's dumping ground for a great mass of internationally owned securities. This sudden selling pressure induced such weakness in the securities market that to prevent the collapse of bank credit exceptional action was taken. New York followed the lead of Paris and London and closed to trading the country's leading securities exchange.

In a number of ways this upset in stock market circles occurred at a very inopportune time. A large block of New York City Subway notes held by foreign capitalists was about to mature, and, moreover, there had been the usual drawing of finance bills in the pre-autumnal period to provide a portion of the funds for the moving of the crops. The expectation was that these bills would be covered out of the proceeds of agricultural exports subsequent to the fall harvesting period.

For the time being, however, there was a virtual stoppage in the export trade and a cessation of active trading in some of the leading articles of commerce. Some time was required for the English and French navies to clear the sea lanes of German raiders, and it was understood that foreign countries must economize wherever possible in the consumption of American products. Food products were necessaries, however, and it is interesting to note that throughout the emergency the Produce Exchange of New York as well as the grain exchanges remained open and did an enormous business. It was perceived that the European purchase of food products could not long be postponed. But the leading product of an entire section of the country, cotton, could not be moved, and its price 
declined in a very brief period from twelve or thirteen to seven or eight cents a pound. No basic article of agricultural production is financed more largely by credit than cotton.

Under these circumstances all sorts of plans were conceived to relieve the strain upon the Southern banks. The "Buy-a-Bale-of-Cotton" movement was launched and projects were formulated involving loans upon cotton evaluated by semi-governmental agencies at prices higher than existing quotations. These plans came to naught, but Northern Bankers were induced to pool their resources by organizing a cotton loan fund.

Gold could not be shipped until the sea lanes were made safe, and, moreover, there was displayed a general disinclination of American bankers to let gold go out of the country. With the cessation of gold shipments sterling exchange moved far above the normal export point.

It was felt generally that these adverse conditions could not continue indefinitely. It was expected that European demand for cotton must finally renew itself, the resumption of export selling would lessen the demand upon our gold, the quieting of conditions in European financial centers would lessen the likelihood of reckless security dumping and make safe the opening of our exchanges. But despite this undercurrent of confidence the shock was of almost unprecedented severity. It is generally believed that the banking system of 1907 would have succumbed quickly in this crisis.

Fortunately the Aldrich-Vreeland Act was available to provide legal sanction for the issuance of bank notes secured by other collateral than Government bonds. It will be recalled that the terms of this act were such as to permit of these notes being issued without much formality. Banks were empowered to organize into associations and the issues would be protected by the collective collateral 
of the association. In August the act was amended by Congress in such a way as to enable the issuance of these bank notes to a larger proportion of the banks' capital than at first authorized. Altogether something like $\$ 380$,000,000 of emergency currency notes were put out. ${ }^{x}$ In many of our cities also large volumes of clearing house certificates were issued. As additional measure of relief the Secretary of the Treasury adopted some rather extraordinary measures. Mr. McAdoo took the position that in a situation so grave, a situation, moreover, in which the provision for emergency issues existed, no bank was justified in refusing legitimate demands of its customers for credit. Consequently, publication was begun of a so-called blacklist in which were stated the names of banks whose reserves were extraordinarily large. Possibly because of the aid rendered by such measures the credit stringency was prevented from becoming acute.

It was undoubtedly unfortunate that the reserve system was not in operation at the time of the crisis. It provided for a reduction in reserves somewhat comparable to the total amount of Aldrich-Vreeland notes and clearing house certificates issued. ${ }^{2}$ IVith its note-issuing powers there would have been little doubt of its ability to meet all legitimate demands. With the reserve banks operating, many of the emergency measures, such as the Cotton Loan Pool and the Foreign Exchange Fund, would have been unnecessary. If the stock exchange could have been kept open, our willingness to pick up at bargain prices the securities of frightened European holders would have been

${ }^{3}$ Cf. Report of the Federal Reserve Board, 1914, p. 15.

'According to figures based upon the Comptroller's call of September 12, the reduction would be $\$ 464919,076$. This makes no allowance, however, for the duplication and triplication of items under the old law. The real cash reduction would be consiferably less. Vice-Crovernor Delano's estimate of the actual reduction was $\$ 250,000,000$. (Cf. Commercial and Financial Chronicle, Novembur 21,1914, p. 1486.) But at any rate the psychological effect was good. 
one of the strongest indications of our financial power. If gold exports could have been maintained freely, Withers ${ }^{x}$ would not have found opportunity for chiding New York at becoming panic-stricken at her first opportunity of supplanting London as the world's banker. He would not have been able to assert that a temporary little difficulty in Lombard Street threw Wall Street into utter confusion. The reserve banks could have furnished all the relief of the emergency measures without outward confession of the existence of strain.

It was felt, however, that it would be a mistake to begin the operation of the reserve banks until its organization was more complete. Inability to function properly might lessen permanently the prestige of the new system. Some difficult readjustments, moreover, would be occasioned by its establishment. For one matter, the transfer of reserve funds from the banks of the central reserve cities to the Federal Reserve banks might create some acuteness in the financial centers. But in a short period financial conditions became less disturbing. By the end of August it was noted that the emergency currency notes were being returned in large quantities and there was less discussion of plans involving the valorization of cotton. Money rates in the financial centers began to ease, and on the last Saturday of October the New York Clearing House report showed that the reserve deficiency which had existed since the outbreak of the European war had been replaced by a substantial cash surplus. The demand for funds, moreover, began to lessen under the influence of reduced speculative activity in the stock market. Accordingly, toward the close of October the Secretary of the Treasury announced that all of the twelve reserve banks would begin operation November 16 .

¿Cf. Hartley Withers, War and Lombard Street, pp. 98-I I I. 
The time of their opening was thus synchronized with the restoration of activity in the export trade. Accordingly, the return to normal conditions was rapid. The first week in December tradings under a minimum price were resumed in the New York Stock Exchange, and shortly thereafter all restrictions were removed. The emergency issues continued to come in for redemption.

In the haste to get the reserve banks into operation they were not equipped at first with full power. The Board was able to issue regulations covering only such operations as were deemed essential to their functioning with reasonable efficiency. In Circular No. 13 addressed to all the Federal Reserve agents on November $10,{ }^{1}$ the Board confined its recommendations to discount operations. Open-market dealings were to be reserved for slow development, and no attempt was to be made for the time being to establish a unified system of clearances.

The discount demands upon the banks immediately after opening were light, however, and the administration's efforts were confined largely to developing the internal organizations of the banks and to the determination of certain broader questions of policy. The most important of the latter was this: What should be the normal place of the reserve banks in our financial structure? Should they be continuously in the market, or should they husband their resources for use primarily in emergencies? There were many at that time who stressed the emergency character of the machinery. It was the outgrowth, it was held, of the movement for banking reform which first reached greatest proportions in the framing of the Aldrich plan. In that project, avowedly, the new machinery in large degree was designed for emergency operation. Except on occasion of financial disturbance the National

'Cf. Report of the Federal Reserve Board, 1914, p. 9. 
Reserve Association's activities would be limited. But in period of credit strain it would offer its notes to the stockholding banks.

It was also argued that the permanent functioning of the reserve machinery must mean undue competition with the member banks. It was insisted that its rediscount rate should normally be higher than the general money rate. If not, its funds would be used to the profit of the banks which rediscounted their paper, and the resources of the system, derived from the contributions of all the banks, would be unavailable in time of disturbance. Partiality in the distribution of its funds must not be permitted. In this vein writes $\mathrm{C}$. W. Barron in his book on the Federal Reserve Act. He states: ${ }^{\mathbf{X}}$

If the new Federal Reserve Board is of the desired quality and character it will be the most unpopular board that ever sat in Washington. It will turn deaf ears to all political and sectional considerations. The greater the clamor for cheap money the tighter it will hold"the reserves within or without the country. It will keep watchful eye upon every section to see that banking facilities for cornering potatoes in Maine, or cotton in Texas; lumber in Oregon or the Carolinas, corn in Illinois, or wheat in Kansas or Minnesota, are absolutely not furnished by any part of the reserve system over which the board presides.

To follow out this argument, the only means of avoiding sectional partiality is to remain absolutely aloof from the money market except on occasion of great need.

In a somewhat similar manner argued Mr. Arthur Reynolds, then President of the American Bankers' Association, in an address delivered on June 27 , I9I4. He regretted that every line of the Reserve Act contained an invitation to rediscount. He feared over-expansion of credit if this invitation was generally accepted. ${ }^{2}$

I Page I3.

2 Sce Commercial and Financial Chronicle, July 4, I914, p. 20. 
A similar view was also the editorial expression of the Commercial and Financial Chronicle. To quote one sentence of their statement: ${ }^{\mathrm{T}}$

The point which should not escape attention is that the reserves having been passed over to the keeping of the Federal Reserve banks, the member banks no longer have any control over them, and yet they are the property of the member banks and their character has not been changed; they are still the reserves of these member banks.

Consequently they should not be dissipated except on occasion of intense need.

These views, however, failed to commend themselves to the reserve management. Unless the reserve banks should get into the market, their earnings would be small. Earnings were held to be necessary to pay the operating expenses of the reserve banks, to yield a dividend on the stock subscriptions, to finance internal developments, and to maintain the prestige of the banks in the eyes of the public. It was argued that the resources of the reserve banks, if employed sparingly and wisely, need not become unavailable for the member banks. They could be invested mainly in such short-time liquid investments as could be convertible into cash without difficulty upon occasion of need.

Time and experience [it was stated] will show what the seasonal variations in the credit demands and facilities in each of the Reserve Banks of the several districts will be and when and to what extent a Reserve Bank may, without violating its special function as a guardian of banking reserves, engage ib banking and credit operations. ${ }^{2}$

The relation between earnings and prestige was stated

- Commercial and Financial Chronicle, January 30, 1915, pp. 334-35.

'Cf. Report of the Federal Reserve Board, 191.t, p. 18. 
as follows in one of the annual reports of the Federal Reserve Bank of San Francisco: ${ }^{\mathrm{X}}$

While there seems no economic defense for an effort under existing conditions to employ a Federal Reserve bank's funds for the purpose of earning profit, yet what may be called the psychological importance of reasonable earnings seems so great as to become a well-defined economic factor. .... Earnings constitute the gauge of success applied by a large section of the public including many bankers. It is characteristically human to uphold the successful enterprise and to obstruct the unsuccessful. A smaller percentage of money reserve, coupled with unqualified approval, will constitute more potent power of support than larger reserves with less or popular confidence.

It was furthermore argued that a piece of banking machinery unused in normal periods could not be made to operate with efficiency on occasions of disturbance. The organization would not be intact when needed. To quote from an address by F. A. Delano, a member of the first Federal Reserve Board: ${ }^{2}$

It might be assumed from what has been said that these twelve Federal Reserve banks exist solely to take care of the unusual, spasmodic or seasonable demands of business, or else those excessive demands which periodically come upon us at greater intervals of time. That alone might well be called a worthy object to attain, but it would have to be admitted that a ponderous and costly machine had been created to serve an additional demand; and it might be doubted whether a machine thus kept in comparative idleness two thirds of the year would operate smoothly and successfully when the steam was turned on.

In its Report for the year 1914, the Federal Reserve Board rejected the theory that continuous operation would lessen the ability of the banks to meet the panic or

' Cf. Commercial and Financial Chronicle, April 8, I9I6, p. I3II.

- Cf. Ibid., February 27, 1915, p. 697. 
emergency needs of their members. What was required was such a control of credit, in times of business optimism as well as of depression, that serious difficulties would never arise. In periods of excessive activity, the banks shoult exercise a restraining influence by withdrawing support from the markets. In periods following extensive liquidation, they should offer their funds freely.

Normally, therefore, a considerable proportion of its resources should always be kept invested by a Reserve Bank in order that the release or withdrawal from active employment of its banking funds may always exercise a beneficial influence.

But no matter what decision should be reached on grounds of business expediency, the reserve administration held the terms of the statute were such as clearly to indicate the desire of the lawmakers that operation should be continuous. Aside from any duty of earning dividends for shareholders, section 14 of the act stated that the rates of discount "shall be fixed with a view of accommodating commerce and industry." For occasions on which there was no demand for discounts, reserve banks were endowed with open-market powers. It seems to the writer that throughout the Reserve Act there is indicated the intention of the lawmakers that reserve banks should do something more than merely to offer emergency relief. The reserve system was intended to operate continuously.

But the problem of getting into the market was one of great difficulty. Because of the reduction in reserve requirements, member banks could expand their loans considerably without engaging in any large amount of rediscounting. In the early part of 1915 the export trade was heavy and gold imports on an enormous scale began. 'The member banks were in so strong a reserve pusition that,

See pp. 17-19 
despite the very moderate rates demanded by the reserve banks, there was no large demand for rediscounts. In this situation, accordingly, the reserve banks were forced to turn to their open-market powers in order to find effective use for their funds. Dealings in Government bonds and municipal warrants were especially large in I9I 5.

But there were limits to the extent to which openmarket purchases could be made with expediency. The reserve system was in its infancy, and it was particularly necessary that it avoid creating the appearance of being a competitor of member banks. The problems' of attracting a larger membership from State institutions and of securing the allegiance of all classes of banks to the voluntary clearance plans had still to be worked out. Despite the fact that the volume of operations at first was not much more than sufficient to meet the expenses of operations, there was a general disposition on the part of member banks to view the reserve banks as rivals and not as servants. Now and then the argument was advanced that the capital stock subscriptions of member banks should be returned. As typical of such views the following utterances may be quoted from an address delivered in August, 1915, by Frank C. Mortimer, Cashier of the First National Bank of Berkeley, California: ${ }^{\mathbf{X}}$

The present law appears to place the Federal Reserve banks in competition with member banks through open market operations. This has already been availed of by the purchase of warrants and other instruments of credit. The abnormally heavy reserves now carried by national banks might have been profitably employed by them, at fair rates of interest, through the purchase of the very obligations now held by the Federal Reserve banks.

The open market operations of the Federal banks are expected, in a measure, to regulate interest rates throughout

${ }_{1}^{1}$ Cf. Commercial and Financial Chronicle, September 18, 1915, p. 888. 
the country and should be exercised in the manner indicated. Since their organization there has been no complaint regarding abnormally high interest charges. Therefore, there appears to be no valid reason for any open market operations at this time.

In buying in the open market the Reserve banks already. have been in competition with member banks, and they appear to have demonstrated that they are operating, not altogether as emergency banks, to be used during periods of financial stress but as open competitors of member banks.

The question naturally arises: At times, when there is no demand for the rediscourting privilege, are the Federal Reserve banks forced to compete with member banks by going into the open market and buying municipal and other warrants, in orler that they may earn expenses and pay the expected dividend of 6 per cent.

If this is the situation, there exists a very good reason for the return of the capitalization to the member banks and the elimination of the implied obligations on the part of the Reserve banks of earning a dividend of 6 per cent.

The return of the capital stock of Federal Reserve banks to member banks has more than incidental bearing on the success of the whole system. With the elimination of this feature, which never has set well upon the national banks, the State banks, recognizing the value of the rediscount feature, in all probability would voluntarily and quickly apply for membership.

The desirability of returning the paid-in capital of the reserve banks will depend upon the reader's conception of the nature of the reserve system. If he believes it desiral,le that the reserve banks should attempt to exercise any large measure of continuous control over the money market, then he would oppose the proposal. Not until the influence of the reserve bank system was more firmly established would it appear feasible to lessen its resources. If, on the other hand, the reserve system is to operate in a purely palliative manner, if it was intended to confine its services primarily to occasions of fmancial disturlanee, greater objection would be made to the capital stock 
feature. For such a system the apparent necessity of earning dividends must prove a frequent source of embarrassment. It might compel the abandonment or modification of policies formulated solely in the interest of financial necessities. But the whole question throws into striking relief the difficulties confronting the management at the beginning of this period. The reserve system must get into the market in order to fulfill its purpose. But the task of getting into the market rendered inevitable many serious problems of financial readjustment. To employ Delano's figure of speech : ${ }^{\mathrm{x}}$

It was like the problem of reconstructing a great office building, changing an antiquated construction and substituting therefor steel and marble, yet accomplishing it all without serious inconvenience to the tenants.

As regards the rate policy of the Board it has been remarked previously that it was believed desirable to act with prudence and conservatism at first. Accordingly, in the first schedule, rates were fixed at from $5^{1 / 2}$ to $61 / 2$ per cent. But as in the case of qualifications for eligibility, ${ }^{2}$ it was soon perceived that these requirements were too high. Accordingly, upon the applications of the various reserve banks the rates were lowered from time to time. On December 30, 1914, the rate on 30-day paper was $4 \frac{1}{2}$ per cent in four districts and 5 per cent in all the others. ${ }^{3}$ Paper of longer maturity commanded slightly higher rates. On this date the differentials were based entirely on maturities.

In 1915 further reductions were made. At the close of the year the rate on bankers' acceptances was 2 to 4 per

I See Bulletin, October I, I9I5, p. 298.

'See supra, Chapter IV, pp. 82-83.

${ }^{3}$ See Report of the Federal Reserve Board, 1914, Exhibit .1, p. 203. 
cent, the lowest figure usually prevailing; and 90-day trade acceptances were discountable in most districts at $3 \frac{1}{2}$ per cent. The 30 -day commercial paper rate was 4 per cent in all districts, save the San Francisco district, where the rate was $31 / 2$ per cent.

Save for a slight tendency toward stiffening at the close of the year, these rates were not altered greatly during $1916 .^{2}$

In order to indicate the general discount situation during these years, the table on page 254 (Table No. I) is presented. The figures show that the total volume of discounts (column 5) increased considerably in 1916 over $1915 ; 1916$ also showed a marked shifting in the maturities of the paper. In 1915 paper maturing in less than 30 days was exceeded both by the 30-60-day paper and the 60-90day paper. In 1916, however, paper of the shorter maturity exceeded all other classes combined. In fact, for the month of December, 1916, discounts of paper maturing within 30 days was considerably larger than the year's total for any of the other classes. This may be interpreted possibly as evidence of the increasing strain upon the money market toward the close of the year. Rediscounting was becoming more general and member banks were offering a more representative lot of paper on their rediscount applications.

As to the district origin of the paper Table No. 2 on page 254 gives information. In I9I5 there was little demand for rediscounts save in the three Southern districts of Richmond, Atlanta, and Dallas. But in 1916 the rediscounts in the Boston, New York, Philadelphia, and Chicago districts compared favorably with those in the three Southern districts.

See Report of the Federal Reserve Board, 1915, Exhibit A, p. 27.

'Cf. Ibid., 1916, Exhibit A, PP. 35-39. 
TABLE No. I

Volume of Discounts for Entire System by Types of Paper ${ }^{1}$

Classification

\begin{tabular}{|c|c|c|c|c|c|}
\hline \multirow[t]{2}{*}{ DAtE } & $\begin{array}{l}\text { MATURING } \\
\text { WVITHIN } \\
\text { 30 DAYS } \\
\end{array}$ & \multirow{2}{*}{$\begin{array}{l}\begin{array}{l}30 \text { DAYS TO } \\
60 \text { DAYS }\end{array} \\
\frac{2}{2}\end{array}$} & \multirow{2}{*}{$\begin{array}{l}\begin{array}{c}60 \text { DAYS TO } \\
90 \text { DAYS }\end{array} \\
3\end{array}$} & \multirow{2}{*}{$\mid \begin{array}{c}\text { AG. PAPER } \\
\text { MATURING } \\
\text { AFTER OO DAYS } \\
4\end{array}$} & \multirow{2}{*}{$\begin{array}{c}\text { TOTAL COM- } \\
\text { MERCIAL PAPER } \\
\text { DISCOUNTET } \\
5\end{array}$} \\
\hline & 1 & & & & \\
\hline \multicolumn{6}{|c|}{ IN THOUSANDS OF DOLLARS } \\
\hline \begin{tabular}{l}
\multicolumn{1}{c}{1914} \\
November \\
December
\end{tabular} & $\begin{array}{r}7,306.2 \\
5,074.5\end{array}$ & $\$ \begin{array}{r}1,929.1 \\
3.250 .9\end{array}$ & $\$ \begin{array}{r}585.6 \\
2,6209\end{array}$ & $\begin{array}{r}128.2 \\
515.6\end{array}$ & $\begin{array}{r}\$ 9,949.1 \\
11.461 .9\end{array}$ \\
\hline $\begin{array}{l}\quad 1915 \\
\text { January } \\
\text { February } \\
\text { March } \\
\text { April } \\
\text { May } \\
\text { June } \\
\text { July } \\
\text { August } \\
\text { September } \\
\text { October } \\
\text { November } \\
\text { December }\end{array}$ & $\begin{array}{l}4,109.3 \\
2,957.5 \\
1,798.6 \\
1,239.0 \\
1,631.5 \\
1,810.3 \\
1,715.9 \\
1,700.3 \\
1,829.9 \\
2,160.4 \\
2,730.8 \\
2,825.7\end{array}$ & $\begin{array}{l}3,627.0 \\
5,421.7 \\
5,257.4 \\
3,500.9 \\
3.800 .8 \\
3.905 .3 \\
4,512.4 \\
4.990 .9 \\
6.180 .0 \\
5,327.4 \\
6.242 .0 \\
5.071 .6\end{array}$ & $\begin{array}{l}2,365.1 \\
3,265.9 \\
5,162.9 \\
4,166.4 \\
4,3.31 .1 \\
5,187.2 \\
5,294.3 \\
4,520.1 \\
5,306.5 \\
5,671.0 \\
6,791.2 \\
5,260.7 \\
\end{array}$ & $\begin{array}{r}611.4 \\
885.2 \\
1,180.8 \\
1,643.0 \\
2,382.3 \\
2,503.2 \\
1,715.4 \\
1,022.4 \\
1,088.6 \\
1,892.0 \\
2,505.7 \\
2.254 .0\end{array}$ & $\begin{array}{l}10.712 .8 \\
12,530.3 \\
13,399.7 \\
10.549 .3 \\
12,145.7 \\
13.406 .0 \\
13,238.0 \\
12,233.7 \\
14,405.0 \\
15,0.50 .8 \\
18,269.7 \\
15,412.0\end{array}$ \\
\hline Total, 1915 & $\overline{\$ 26,509.2}$ & $\overrightarrow{\$ 57,837.4}$ & $\overline{\$ 57,322.4}$ & $\$ 19.684 .0$ & $\$ 161,353.0$ \\
\hline $\begin{array}{l}\text { January } \\
\text { February } \\
\text { March } \\
\text { April } \\
\text { May } \\
\text { June } \\
\text { July } \\
\text { August } \\
\text { September } \\
\text { October } \\
\text { November } \\
\text { December }\end{array}$ & $\begin{array}{r}2,118.8 \\
1,104.3 \\
1.202 .1 \\
4,363.9 \\
3,220.0 \\
3.271 .6 \\
10.645 .0 \\
8.339 .6 \\
5.342 .6 \\
4,392.7 \\
13.497 .3 \\
57.555 .5 \\
\end{array}$ & $\begin{array}{r}\$ 3,359.2 \\
2,558.4 \\
3,176.7 \\
2,373.2 \\
2,623.3 \\
2,377.6 \\
2,747.5 \\
3,447.3 \\
3,898.4 \\
3,492.6 \\
1,626.1 \\
2,742.6 \\
\end{array}$ & $\begin{array}{r}\$ 4,121.6 \\
2,995.8 \\
3,805.5 \\
3,017.1 \\
2,961.3 \\
3,084.4 \\
4,965.8 \\
4,521.7 \\
4,107.4 \\
3,126.4 \\
1,895.9 \\
2,973.7 \\
\end{array}$ & $\begin{array}{r}\$ 1,515.4 \\
1,006.1 \\
1,203.0 \\
1,767.3 \\
2.390 .9 \\
2.926 .4 \\
1,824.7 \\
1,043.2 \\
960.4 \\
851.5 \\
884.8 \\
442.2 \\
\end{array}$ & $\begin{array}{r}\$ 11,115.0 \\
7,664.6 \\
9.387 .3 \\
11,521.5 \\
11,195.5 \\
11,660.0 \\
20,183.0 \\
17.351 .8 \\
14,308.8 \\
11,862.9 \\
17,904.1 \\
63,716.0 \\
\end{array}$ \\
\hline Total. 1916 & $\$ 115,053.1$ & $\$ \overrightarrow{34.422 .9}$ & $\$+1.576 .6$ & $\$ \longdiv { \$ 1 6 , 8 2 5 . 9 }$ & $\$ \longdiv { 2 0 7 . 8 7 0 . 5 }$ \\
\hline
\end{tabular}

1 Figures taken from A nnual Reports of the Federal Reserve Board.

TABLE No. 2

Distribution of Discounts by Dist Ricts

\begin{tabular}{|c|c|c|c|c|}
\hline \multirow{3}{*}{ DISTRICT } & \multicolumn{4}{|c|}{ IN Thousands of Dollars } \\
\hline & \multicolumn{2}{|c|}{ Nov. 16, 1914-DEC. 31, 1915} & \multicolumn{2}{|c|}{ JAN. 1, 1916-DEC. 31, 1916} \\
\hline & AMOUNT & $\begin{array}{l}\text { PER CENT } \\
\text { IN } 1915\end{array}$ & AMOUNT & PER CENT \\
\hline Boston. & $\$ 2,386.9$ & 1.3 & $\$ 33,921.9$ & 16.3 \\
\hline New York.... & $9,668.7$ & 3.0 & $22,329 \cdot 5$ & 10.7 \\
\hline Philadelphia. & $6,839.7$ & 3.2 & $22,328.4$ & 10.7 \\
\hline Cleveland.... & $5,201 \cdot 3$ & 2.8 & $6,792.4$ & 3.3 \\
\hline Richmond ... & $47,076.1$ & 27.8 & $34,377.2$ & 16.5 \\
\hline Atlanta..... & $35,336.6$ & 21.2 & $22,323.2$ & 10.7 \\
\hline Chicago ..... & $14,6+8.5$ & 5.7 & $23,178.1$ & 11.2 \\
\hline St. Louis..... & $8,231.2$ & 3.9 & $8,842.7$ & $4 \cdot 3$ \\
\hline Minneapolis. & $5,870.3$ & 3.2 & $6,473 \cdot 5$ & 3.1 \\
\hline Kansas City. . & $11,3^{85} \cdot 3$ & 6.8 & $6,817 \cdot 7$ & 3.3 \\
\hline Dallas....... & $27,795.8$ & 16.6 & $18,512.5$ & 8.9 \\
\hline S.n Francisco & 8.3266 & 4.5 & $1,97,3.4$ & 1.0 \\
\hline
\end{tabular}


DEVELOPMENT, NOV., 1914, TO DEC., 1916255

During these years discounting for banks in the Nation's financial center, New York City, was conspicuous because of its almost total absence. The exceptional nature of rediscounts for the metropolitan institutions is indicated by the following statement issued by the New York Federal Reserve Bank early in December, I9I6: 1

During the course of the day a number of New York City banks, including among others . . made use of the rediscount facilities of the Federal Reserve Bank of New York. While the amounts of the rediscounts were not large, the facility and promptness with which the credits were obtained serves to illustrate in a practical way, for the first time in the history of the bank, the readiness of the Federal Reserve system to meet the calls made upon it. The officers of the Reserve Bank expressed themselves as much gratified with the attitude of the member banks in making use of their facilities, it being apparent that the rediscounting had been undertaken not so much because there was any necessity for it, but rather to inaugurate the practice which, while already a commonplace at other Federal Reserve banks, had not heretofore become an established procedure in New York.

The number of member banks accommodated through the discount of commercial paper was somewhat similar in the two years. In I916, 23.4 per cent of all member banks received discount credits from reserve banks. The figures for 1914, 19I5, and I9I6 were as in Table No. 3 on page 256.

According to the figures of Table No. 4 on page 256, the amount of paper most commonly discounted during I9I6 was $\$$ I 000 to $\$ 2500$. But approximately an equivalent amount of pieces in size from $\$ 250$ to $\$ 500$ and $\$ 500$ to $\$ 1000$ were discounted. More pieces of paper under $\$$ Ioo

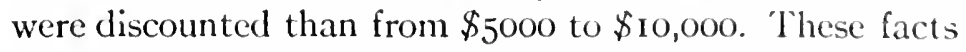

${ }^{1}$ Cf. Commercial and Financial Chronicle, Decenber 9, 1916, p. 2118. 


\section{TABLE No. 3}

Number of Member Banks Accommodated Through Discount of Commercial Paper

\begin{tabular}{|c|c|c|c|}
\hline District & Nov. 16, 1914-DEC. 31, 1915 & 1915 & 1916 \\
\hline Boston. ............ & 29 & I9 & 56 \\
\hline New York. ......... & 54 & 49 & 62 \\
\hline Philadeiphia........ & 70 & 65 & 143 \\
\hline Cleveland........... & 88 & $8 \mathrm{I}$ & 50 \\
\hline Richmond......... & 226 & 226 & 202 \\
\hline Atlanta. . . . . . . . . & $24^{8}$ & 247 & 209 \\
\hline Chicago........... & 221 & 143 & 212 \\
\hline St. Louis. . . . . . . . . & 131 & 129 & II4 \\
\hline Minneapolis. . . . . . . . & 197 & 176 & 174 \\
\hline Kansas City........ & 274 & $25^{8}$ & 189 \\
\hline 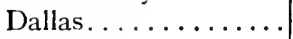 & 366 & 360 & 301 \\
\hline San Francisco. . . . . . . & 169 & 167 & 76 \\
\hline Total.... & 2,073 & 1,920 & 1,788 \\
\hline
\end{tabular}

TABLE No. 4

Commercial Paper Discounted by Size for the Year $1916^{1}$

\begin{tabular}{|c|c|c|}
\hline SizE & Number of Pieces & $\begin{array}{c}\text { Amoun in Thousands } \\
\text { OF Dollars }\end{array}$ \\
\hline To $\$ 100 . . . .$. & 4,407 & $\$ 322.6$ \\
\hline$\$ 100-250 \ldots \ldots \ldots \ldots$ & 12,088 & $2,137 \cdot 4$ \\
\hline $250-50 . \ldots \ldots \ldots \ldots \ldots$ & 14,551 & $5,670.8$ \\
\hline $500-1000 . \ldots \ldots \ldots \ldots$ & 14,907 & I I, 39I.5 \\
\hline $1000-2500 \ldots \ldots \ldots \ldots$ & I 5,460 & $26,120.4$ \\
\hline $2500-5000 \ldots \ldots \ldots \ldots$ & 9,608 & $38,756.2$ \\
\hline $5000-10,000 \ldots \ldots \ldots \ldots$ & 3.391 & 26.750 .9 \\
\hline Over $\$ \mathbf{r} 0,000 \ldots \ldots \ldots$ & $\mathbf{I}, 87 \mathbf{I}$ & 96.720 .7 \\
\hline Total...... & $\overline{76,283}$ & $\overline{207.870 .5}$ \\
\hline
\end{tabular}

1 See Report of the Federal Reserve Board. 1916, p. 91.

tend to combat the assertion that the principal advantages of the reserve system would enure to the large borrower.

Table No. 5 on page 257 gives certain information regarding the amount of the open-market purchases during 1915 and 1916. 
TABLE No. 5

Total Investment Operations (Purchased Paper and Discounted PAPER)

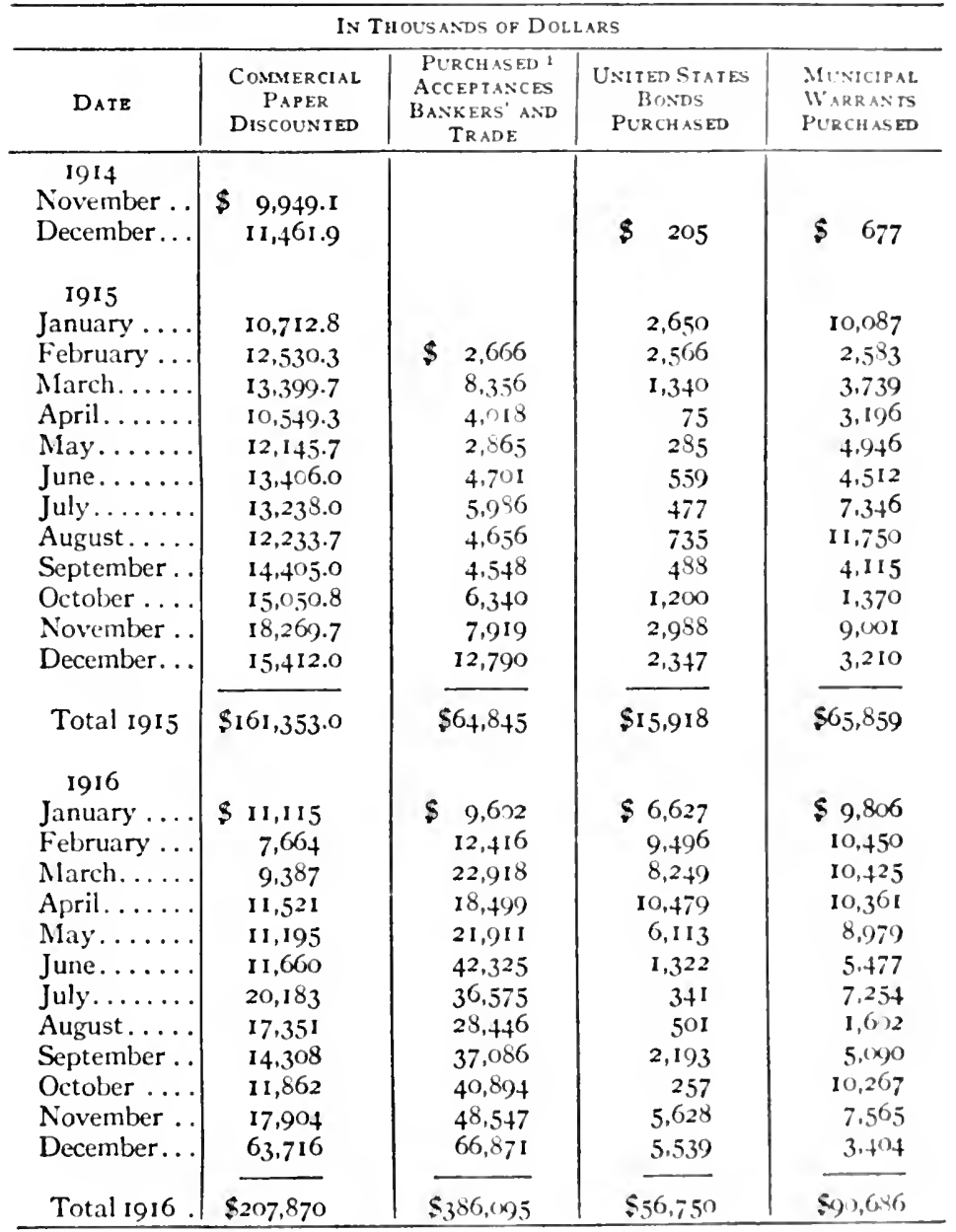

1 First purchase of acceptances, February 19, 1915.

By means of these operations the reserve banks were able to make a fair showing regarding carnings in 1915 
and 19i6. In these two years all earned expenses and were able to contribute a small amount to dividends. From the Report of the Federal Reserve Board for the year 1916 we read: ${ }^{\text {I }}$

The figures for the whole system to December 31, 1916, show an average net earning since organization of 3 per cent on the actual paid-up capital, while for the year I9I6 they show an average net earning of 5 per cent.

In comparing reserve banks' operations with those of private institutions, it must be remembered, however, that a portion of their capital is obtained without the issuance of stock. The law required member banks to deposit a portion of their reserves with the reserve banks.

Because of the rather limited scale of its operations, the reserve system approached the close of this period with exceedingly high reserves. December 30, 1916 , the ratio of the gold reserves of the reserve banks to the net deposit and Federal Reserve note liabilities was 79.4 per cent. On this date the cash reserve ratio was 81.4 per cent.

Despite the limited demands upon its resources, it appears undeniable to the writer that in this period the reserve management should be credited with a remarkable achievement. The legitimate needs of business were met without the sacrifice of principle on the one hand or the establishment of unduly bureaucratic methods upon the other. The requirements for eligibility of paper presented for rediscount were fair. The practice of discounting had become sufficiently prevalent to point the way to member banks for the solution of their future emergency requirements. Analysis of the number of banks served, of the size of the paper discounted, of the districts of origin, gave results which could not be employed to justify charges of favoritism. The reserve management had convinced the

$\therefore$ Page I3. 
DEVELOPMENT, NOV., I914, TO DEC., I916 259

member banks that its services were at the disposal of all banks and all districts.

While progress in popularizing the trade acceptance was slow, it had proceeded upon a sound basis. The firms won over to its use were in large measure those of high credit rating. Progress in the popularization of the bankers' acceptance was favorable.

In check collections the reserve system had proceeded slowly but cautiously. But by the middle of 1916 the foundations had been laid for a country-wide par clearance scheme which was finally to include the greater part of the country's banks, non-member as well as member. 'These steps had to be taken in the face of much legislative and political objection engendered by the large number of exchange-charging banks.

By amendments to the act and various administrative measures, much progress had been made in the movement to conserve the Nation's gold supply. On December 29, I9I6, its total gold reserve was $\$ 45,3,000,000$. On the same date a total of $\$ 282,000$,000 was deposited with the reserve agents as cover for the Federal Reserve note issues. The reserve banks were accumulating gradually a larger and larger portion of the country's gold. This concentration of gold increased the reserve system's power for evil as well as for good. But it would not have been courageous to have declined to accept this opportunity.

No occasions for inter-district rediscounting occurred in this period. But knowledge of the possililities of securing extra-district aid enabled industry to count upon the support of its banks with greater certainty.

In the Gold Settlement Fund at Washington the heginnings had been laid for a machinery which finally was to enable clomestic transfers of currency to be made with a minimum of cost and physical effort. 
The principal disappointment had to do with the refusal of the great majority of State banks to enter the system. But it seems clear that only by undesirable concessions could the system have been made such as to attract the voluntary entrance of many.

Lastly, the internal organization had been developed to meet the requirements of the future. The preliminary work had been accomplished. This period was one of achievement. But primarily the achievements were those of preparation. 


\section{CHAPTER XIII}

FEDERAL RESERVE DEVELOPMENT, JANUARY, I917 TO APRIL, I9I7

IN the early period of reserve operation the demand for rediscounts was light and the reserve banks were able to exercise little control over the money market. Toward the close of 1916, however, the general boom in industry had begun to throw some strain upon the credit mechanism. As a consequence several reserve banks in December, 1916 , increased their rates slightly and for the first period of their existence the member banks became somewhat sensitive to their rediscount policy. As stated by Governor Harding in the January, 1919, Bulletin:

the only period when the Federal Reserve Board was able to exercise any effective control over the banking situation was during the last two or three months of 1916 and the first quarter of $19170^{x}$

It might be expected, accordingly, that 1916 would mark the close of the period of experiment and preparation, and that permanent principles governing rediscount and open-market operations would soon crystallize. Prior to 1917 there was no danger of credit and currency inflation. The inflow of gold from Europe and the reduction of reserve requirements by the terms of the act left menber banks in an exceedingly strong reserve position. Under this situation member banks could provide credits without great deference to the policy of the reserve administration. There was then little objection to be made to the low

- Page 2. 
rates. Rather they appeared to be an outright advantage. In the first place, these low rates tended to encourage member banks to make rediscount applications and thus emphasized the helpful possibilities of the system. Secondly, they served to indicate the fundamental soundness of America's financial condition.

No system of central banking, however, can continue forever to serve as an agency for credit expansion, and it might be expected, accordingly, that in 1917 a beginning would be made in establishing a permanent basis for advances to member banks. The principle accepted might be to keep the reserve banks' rates above those of the general market or to base the volume of rediscounts upon the productive requirements of the community where the applications arose. But no matter what the basis of procedure, it was clear to all thinkers that in the first two years of operation no real progress had been made in this direction. Financial conditions in these years were such as to make unnecessary the solution of this problem.

As political events shaped themselves, however, neither I9I7 nor any subsequent year was to be such as to permit idealistic consideration of the proper basis for rediscount operations. Very early in I9I7 it became clear that only by receding from our oft-stated position regarding the rights of neutrals armed clash with Germany could be avoided. Prospects of entering the conflict overshadowed all other considerations, and the task of the reserve administration was to place the reserve banks in shape to meet the financial strain of war. It was understood that the Treasury's plan would involve huge borrowing operations and that these could be rendered successful only by the active coöperation of the banks. Credits would be required, not merely to finance our own expenditures, but also those of our allies whose purchase of war supplies in 
DEVELOPMENT, JAN., 1917, TO APRIL, I917 263

this country would increase as a result of our declaration of war. A credit system, moreover, not efficiently ordered before war, could scarcely be expected to be prepared during hostilities for the requirements of post-war reconstruction. The problem then would exist of transferring labor and capital from the production of war supplies to the industries of peace.

It was during this period, accordingly, that much of the work of concentrating the control of the country's gold was accomplished. In January the Board proposed the amendments which became law June 21, 1917, and which required member banks to maintain their entire legal reserves with reserve banks. The Board also suggested that it be given power to raise the reserve requirements of member banks in emergencies. Congress refused, however, to accept this amendment. At the same time proposals were made to render membership more attractive to State banks and trust companies and preparations were made for ensuring an adequate supply of Federal Reserve notes.

During the months of January and February it placed additional orders with the Bureau of Engraving and Printing, through the Comptroller of the Currency, for more than $\$ 900,000,000$ of notes, and arranged also that the stock of notes on hand should no longer be reduced through withdrawals for current needs, but that as drawn upon by the Federal Reserve Banks new orders in equal amount should be placed automatically. ${ }^{x}$

In view of the anticipated future strain it might have been expected that discount rates would have been increased during this period. The state of the money market, however, was such as to necessitate comparatively few alterations. For instance, the rates on commercial paper maturing within 6I to 90 days were increased

Report of the Federal Reserve Board, 1917, p. 2. 
in this period in only two districts. In January, the Atlanta and Dallas banks increased their charges one half of one per cent.

With these rates the discounts for member banks of the first quarter of the year totaled $\$ 67,523.7$ thousand. This compares with totals of $\$ 28,166.9$ thousand and $\$ 36,642.8$ thousand in the corresponding periods of 1916 and 19I5. The dependence of member banks upon rediscounting was increasing somewhat.

It might be surmised that this increased rediscounting must have been at the expense of the reserve banks' legal reserves. It is true that the reserve accounts of members on the books of reserve banks increased somewhat. On January 26 , members' reserve accounts were $\$ 687,84 \mathrm{I}$, 000. On February 23, they were $\$ 692,475$,000 and on March 30, $\$ 720,4$ I I, 000. The circulation of Federal Reserve notes, on January 26, was $\$ 259,768$,000; on February 23, $\$ 303,17 \mathrm{I}, 000$; and, on March 30, $\$ 357,610,000$. But as a result of the continuous impounding of gold the total cash reserves advanced steadily from $\$ 758,242$, o00 on January 5 to $\$ 962,662$,o00 on April 6. ${ }^{x}$ Consequently, the ratio of cash reserves to aggregate net deposits and Federal Reserve note liabilities remained continuously above 82 per cent. On April 6, the date of the declaration of war, it was 84 per cent.

The enlarging gold holdings of the reserve banks made possible also an increase in the open-market investment operations without lowering the reserve ratio. This is indicated by the table on page $265^{2}$

On January $5,1917,{ }^{3}$ the gold of the reserve banks in excess of required reserves - free gold, in other

3 Report of the Federal Reserve Board, 1917, p. 64.

I Ibid., p. I3I.

3 Ibid., p. 70. 
DEVELOPMENT, JAN., I917, TO APRIL, 1917265

\begin{tabular}{|c|c|c|c|}
\hline \multirow{2}{*}{ YEAR } & \multicolumn{3}{|c|}{ 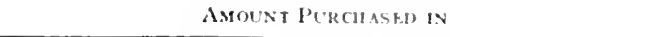 } \\
\hline & JANUARY & TEBRUary & $\mathrm{M}_{\mathrm{ARCH}}$ \\
\hline $1917 \ldots \ldots$ & $\$ 49,105,3.56$ & $599,5^{\circ 2}, 895$ & $\$(6,+195,153$ \\
\hline $1916 \ldots . .$. & $37,150,980$ & $4^{0,028,95^{\prime \prime}}$ & $\left.5^{(0)},(5) 1,15^{\circ}\right)$ \\
\hline $1915 \ldots \ldots$ & $23,45^{\circ}, 300$ & $20,3+5,800$ & $26,83+,(x)$ \\
\hline
\end{tabular}

words - amounted to $\$ 421,155,000$. On April 6 it had increased to $\$ 545,959,000$. On the basis of this free gold an enormous expansion of credit advances to member banks or of Federal Reserve note issues was possible. This free gold would provide a 40 per cent reserve for a deposit or note expansion of $\$$ I, I $64,697,500$. This would exceed the sum of the outstanding Federal Reserve note circulation and book credit advances to member banks $(\$ 1,134,729,000)$ by $\$ 29,978,500$. And the process of attracting gold into the reserve reservoir had yet to attain full proportion. Few State banks had joined the system, and the amendment of June 21 , I9I7, requiring member banks' legal reserves to be kept in their entirety in reserve banks, had not yet been enacted.

In view of the fact that this period closes before the amendment of June $2 \mathrm{I}$, I $9 \mathrm{I} 7$, and in view of the further fact that the reserve banks' reserves were to be enlarged by successive accretions of gold, it would be unprofitalle to calculate the amount of credit and note-issue expansion which the reserve banks' reserves would support on the date of the outbreak of the war. But a few facts relating to the conditions of member banks will serve to enable us better to understand the credic situation at this time.

March 5, 19I7, the required reserve for the net deposits of member banks was not quite 15.5 hundred millions of dollars. On this date the actual reserve (vault reserve, plus amount due from Federal Reserve banks plus amount due from reserve agents) was almost 20.5 hundred 
millions. Irrespective of any further aid to be secured through rediscounts, the member banks, as a whole, were in an exceedingly strong reserve position.

These facts should not be interpreted, however, as providing solely a basis for congratulation. It is true that the public and the banks were destined to support a war finance programme of unparalleled magnitude. It is also undebatable that without the Federal Reserve all this would have been impossible. But it is still true that the huge surplus reserves gave a false sense of security. They seemed to justify expenditures by the Government of any amount for any purpose. Much delay and many mishaps were to be encountered before it came to be realized that the problem of war finance was not primarily one of supplying dollars, but rather one of securing for war purposes labor and materials. Some time was to elapse before it could be understood generally that labor and materials were limited in supply even if dollars were not.

${ }^{x}$ Cf. Bulletin, June I, I9I7, p. 484. 


\section{CHAPTER XIV}

FEDERAL RESERVE DEVELOPMENT, MAY, I917,

TO NOVEMBER II, I9I 8

TIIE general policy of the Federal Reserve administration during the period of our participation in the World War may be epitomized briefly as one of complete and cordial coöperation with the Treasury. Once the Treasury had announced its plans, the banking machinery was adapted, so far as possible, to the work of furnishing the necessary financial support. To quote from the Bulletin for January I, I9I8: ${ }^{\mathrm{I}}$

Under the leadership of the Secretary of the Treasury ${ }^{2}$ the banks have done their duty admirably in placing both the short- and long-term securities of the Government.

The financial story of the war can thus be read to a very large extent in the policies of the Federal Reserve Board.

The first respect in which the reserve banks were called upon to lend their facilities to the Treasury was in connection with the sale of short-term Treasury certificates. Only to a limited extent were funds for war purposes obtained in advance of disbursements by means of taxation or bond sales. In large measure funds would be acquired first through the sales of short-term certificates. Upon their due dates the accumulated certificates would be retired through the proceeds of taxation and bond sale's.

The Treasury announced at an carly date its intention to follow this policy. On April 20, 1917, Secretary Mc:ldoo

Page $\mathbf{r}$.

Italics are the writer's. 
stated that as soon as the War Loan Bill became law several hundred million three per cent certificates, payable June 3o, would be issued. ${ }^{x}$ In order to avoid temporary shortage of banking funds in the communities where the certificates were purchased, the Treasury stated that disbursements would be made in such a way "that as far as possible money paid in will be promptly returned to the market." 2 But in case these measures should prove insufficient, it was announced by Governor Harling that ${ }^{3}$ "the Federal Reserve Banks may be counted upon by offering liberal terms of rediscounting to do their utmost in counteracting any effect of temporary dislocation of banking funds." Within a month there were three issues of these certificates totaling $\$ 650,000,000$.

But what specific measures should be provided to render effective this offer of support to member banks? It was evident that no alterations need be made in the laws or regulations governing eligible paper. The original act permitted the reserve banks to rediscount customers' paper drawn for the purpose of carrying bonds of the Government of the United States. Since the amendment of September 7, I9I6, provision had existed for the direct discount of member banks' promissory notes secured by "pledge of bonds or notes of the United States" as well as by eligible paper. Federal Reserve support was in large measure, therefore, a question of the rates of discount.

In the Bulletin of June I, I9I7, we read : ${ }^{4}$

The Board, therefore, recently took under consideration the question of establishing a rate of discount for the short-term notes of member banks secured by Liberty bonds or by shortterm certificates as collateral, as well as the question of a favor-

x Bulletin, May I, I917, pp. 34I-42

I Ibid.

3 Ibid., p. $3+2$.

4 Page 425. 
able rate of rediscount for customers' notes collateraled by such bonds or certificates and offered by the member banks to the reserve banks with their own endorsement.

As a result of this consideration the Board announced in May its willingness to approve a rate of 3 per cent on member banks' notes collateraled by war pajer. On May' 22 , it issued a circular stating that it would ratify a rate of $3 \frac{1}{2}$ per cent on the rediscount of customers' notes maturing within ninety days secured by Government bonds or Treasury certificates. Since the first war bonds bore interest at $3 \frac{1}{2}$ per cent, the bond subscriber was ixirly well protected against the dangers of subscriptions exceeding his ability to pay.

Inasmuch as the rate of interest increased on later issues of war bonds, it would be expected that the reserve banks' rates would increase also. Accordingly on the date of the armistice the rate was $4 \frac{1}{4}$ per cent on $16-90$-lay paper secured by war issues. In addition to these measures some use was made of a $3-4 \frac{1}{2}$ per cent rate on one-day discounts arising in connection with the Government's loan operations.

It did not seem feasible to the reserve management to establish high rates on other types of paper even in this period of capital-strain. All rates of interest are more or less closely related. High money charges exacted from the public on business loans would increase the difficulty of selling war bonds at low rates. Accordingly the 9o-day rate on commercial paper, which on April 30, 1917, was 4 per cent in five districts, and $4 \frac{1}{2}$ per cent in seven, was advanced only slightly during the period of hostilities. On the date of the armistice it was $43 / 4$ per cent in seven districts and 5 per cent in the others.

But the reserve banks did not confine their efforts to keeping their own rates low. In many ways they endeav- 
ored to bring pressure on member banks to offer loans to the public cheaply, as well as to maintain low rates on deposits. For instance, in the schedule of rates for October 3I, I9I8, the member banks' ability to secure a 4 rather than a $4 \frac{1}{4}$ per cent rate would depend, in two districts, upon whether the customer's paper had been discounted at a rate not exceeding that borne by the bonds. On several occasions we find the reserve administration cautioning banks against raising rates allowed on deposits. To quote from a letter by Governor Harding of February 26, I918: ${ }^{\mathrm{I}}$

Banks should remember that when deposits are reduced reserves are released. Reckless competition for deposits supported by high interest rates will tend to force the Government to pay higher rates, thereby imposing additional burdens on the people; and any forced and artificial expansion of banking credits will promote rather than check inflationary tendencies, which should be guarded against at the present time. There does not seem to be any demand on the part of depositors for increased rates of interest on their balances, and the Board wishes it understood that it does not favor any movement to increase these rates and that it will do all in its power to discourage it.

Because of the enormous demand upon the reserve banks' rediscounting facilities during the war, mere suggestions from the Board were undoubtedly more than ordinarily efficacious. But enough has been stated to indicate the complete coöperation of the reserve banks with the Treasury. The writer has found no important instance in which there was displayed an unwillingness to refuse support for the Treasury's low interest policy in the sale of war bonds.

In the preceding chapter ${ }^{2}$ some information has been

See Bulletin, April I, I9I8, p. 252.

'See supra, pp. 264, 265. 
DEVELOPMENT, MAY, I9I7, TO NOV. II, I9I8 27I given regarding the ability of the reserve and member banks to meet the demands upon them. There it was shown that, at the outbreak of hostilities, the member banks' surplus reserves were huge and that the free gokl of the reserve banks would permit more than a doubling of the issues of Federal Reserve notes and of credit advances to member banks. But the expansive possibilities of the system should be calculated on a date subsequent to the amendment of June 21,1917 , which lowered reserve requirements and provided for their transfer in entirety to reserve banks. Since the Comptroller's figures bearing upon the condition of national banks may be had for November 20, 1917 , the writer has selected November 23 as the date for his calculations as to the amount of bank credits the surplus reserves of reserve banks might enable member banks to grant the public. All figures are given in thousands - i. e., ooo omitted."

I. Gold reserve for federal reserve notes.

On November 23, 1917, the gold reserve for note issues totaled $\$ 635,497(\$ 623,948$ (leposited with the reserve agents plus $\$ 11,549$ in the gold redemption fund).

On this date the notes in actual circulation totaled \$1,051,892. The actual gold reserve was $\frac{635,497}{1,015,892}$ or 62.5 per cent. The minimum 40 per cent required would be $\$ 406,356$.

The excess reserve for notes was $\$ 635,497$ less $\$ 406,356$ or $\$ 229$, I40.

2. Possibilities of further note expansion.

Supposing the excess reserve for notes to be used to support the maximum value of notes, a further note issue is possible of $21 / 2$ times $\$ 229,140$ or $\$ 572,850$.

3. Reserve for member bank deposits.

"This calculation is quoted from H. L. Reed, "Creclit Expansion under the Federal Reserve," American Economic Reviewe, Junc, 19) I8, 111). 270-82. Sice pp. $279,280$. 
On November 23, 1917, the net deposits of all the reserve banks totaled $\$ 1,546,122$; computed as follows:

Government deposits............. 196,4 I I

Due to members (reserve account) . . . . . I,426,648

Due to non-members (clearing account)... 22,29 I

Collection items.............. 215, 169

Total gross deposits.............. $\quad \$ \$ 1,860,519$

Due from other reserve banks, net ....... $\$ \mathrm{II}_{1,872}$

Uncollected items................. 302,525

Total deductions................. $\quad 314,397$

Net deposits.................. \$ \$1,546,122

The gold reserve for net cleposits totaled $\$ 969,207$, as follows:

Gold coin and certificates in vault........\$530,045

Gold settlement fund............... 385,662

Gold with foreign agencies............ 52,500

Total. ............................\$969,207

The gold reserve for deposits was $\frac{969,207}{1,546,122}$ or 62.6 per cent.

The total lawful money reserve for depos-

its (gold reserve plus legal tender notes,

silver, etc.) was $\$ 969,207$ plus $\$ 54,058$

or. . . . . . . . . . . . . . $\$ 1,023,265$

The lawful money reserve required ( 35

per cent minimum) would be...... 54I,I42

The surplus reserve for deposits was. . . \$ 482,123

4. Possibilities of further expansion of deposit credits of reserve banks.

-Supposing the"surplus reserve for deposits to be used to support the maximum volume of member bank deposits, an increase in these is possible of $\frac{I O O}{35}$ times $\$ 482,123$ or $\$ 1,377,494$. This represents a potential increase of more than 95 per cent. (Member bank deposits with reserve banks on November 23 equaled $\$ 1,426,000$.)

5. Possibilities of further expansion of deposit liabilities of member banks. 
Supposing that the required reserve for member banks averages Io per cent, and that the $\$ 1,377,49+$ should be used to the maximum amount to support their deposit grants to the public, an increas? in these is possible of to ro times $\$ 1,37 \pi+49+$ or $\$ 13.774,940$. This represents a potential expansion of more than 90 per cent. (Total deposit liabilities of national banks on November 20, were $\$ 14,798,000$.) An increase of note issues by $\$ 572,850$ would probably furnish all the till money necessary to support the $\$ 13,774,940$ of bank deposits.

But even these figures do not show the full possibilities of credit expansion on this date. No account is taken of the huge surplus cash then reposing in the vaults of member banks. Much new gold, moreover, was to continue to accumulate in the vaults of reserve banks and many large and powerful State institutions were yet to enter the system.

To what extent we may next inquire was this expansive power of the Federal Reserve utilized during the period of hostilities? The following figures show the amount of the total investment operations of reserve banks.

1917

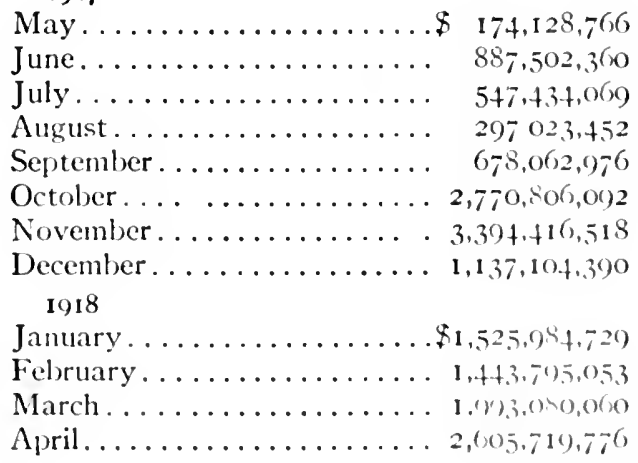

- Figures do not include rediscounts and sales of discounterl paper between Federal Reserve banks nor purchases of Unitel States cert ificates of indebted. ness. See Report of the Federal Rescrve Board, 1918, pp. 191-1)2. 


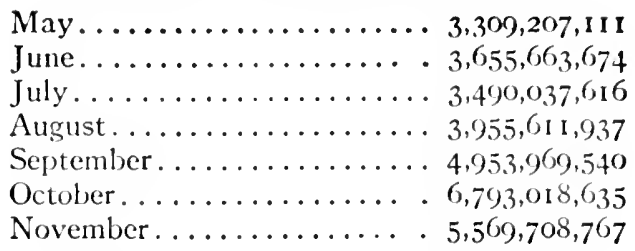

The following table shows the changes in the reserve banks' total earning assets, member banks' reserve account, and Federal Reserve notes in actual circulation for various lates: ${ }^{\mathbf{x}}$

\begin{tabular}{|c|c|c|c|}
\hline \multicolumn{4}{|c|}{ OOO'S OMitTED } \\
\hline DATE & $\begin{array}{c}\text { Total Earning } \\
\text { ASSETS } \\
\end{array}$ & $\begin{array}{l}\text { FEDERAL RESERVE } \\
\text { NOTES IN ACTUAL } \\
\text { CIRCULATION }\end{array}$ & $\begin{array}{l}\text { MEMBER BanKS' } \\
\text { RESERVB } \\
\text { ACCOUNI }\end{array}$ \\
\hline 1917 & & & \\
\hline April $27 \ldots \ldots$ & $\$ 239,260$ & $\$ 420,509$ & $\$ 719,785$ \\
\hline May $25 \ldots .$. & 287,297 & 454.402 & 813.326 \\
\hline June $29 \ldots \ldots$ & 494,536 & . 508,753 & $1,033,+60$ \\
\hline July $27 \ldots \ldots$ & $411,97^{8}$ & 534, OI 5 & $I, 135,456$ \\
\hline August $31 \ldots$ & $3^{81,063}$ & 587,9 I 5 & $1,069,804$ \\
\hline Septemler 28 & 504,937 & 700,212 & $1,136,930$ \\
\hline October $26 \ldots$ & 684.959 & 847,506 & $1,264,323$ \\
\hline November 30 & $1,052,377$ & $1,056,983$ & $1,489,370$ \\
\hline December 28. & $1,064,310$ & $1,2+6,488$ & $I, 453, I 66$ \\
\hline 1918 & & & \\
\hline January $25 \ldots$ & $\$ 1,029,670$ & $\$ 1,234,934$ & $\$ 1,480,743$ \\
\hline February 2 I .. & $1,031,797$ & $1,314,581$ & $I,+59,720$ \\
\hline March 28-29. & $1,201,5^{35}$ & $I, 452,838$ & $1,499,400$ \\
\hline April 26. . . . . & $1,286,162$ & $1,526,232$ & $1,497,416$ \\
\hline May $31 \ldots .$. & $1,301,390$ & $1,600,968$ & $1,440,413$ \\
\hline June $23 \ldots \ldots$ & 1,345 , I I 2 & $1,722,216$ & $1,557,5^{87}$ \\
\hline July $26 \ldots .$. & $1,564,540$ & $\mathbf{1}, 870,835$ & $1,435,196$ \\
\hline August $30 \ldots$ & $1,716,987$ & $2,092,708$ & $1,478,639$ \\
\hline September 27 . & $2,080,566$ & $2,3+9,326$ & $1,535,490$ \\
\hline October $25 \ldots$ & $2,295,122$ & $2,507,912$ & $1,653,499$ \\
\hline Novenber 29. & $2,312,359$ & $2,568,676$ & $1,488,893$ \\
\hline
\end{tabular}

Some surprise may be evoked by the fact that the growth of the note issues was so much greater than that of the book credits granted to member banks. This is

× See Reports of the Federal Reserve Board, 1917, p. 60; 1918, pp. 122 and 117. 
DEVELOPMENT, MAY, 1917, TO NOV. II, 1918275

explained in large measure, however, by the fact that the notes were being substituted for gold in the general circulation. The process was one by which notes were issued to meet member banks' counter-money needs and the gold of the reserve banks was being deposited with the Federal Reserve agents as cover. This is shown by the following figures:

Gold Cover for Federal Reserve Note Circulation 1

(000,000's OMITTED)

DATE

1917

June $29 \ldots \ldots \ldots \ldots \ldots \ldots \ldots 402$

July $27 \ldots \ldots \ldots \ldots \ldots \ldots \ldots \ldots, 434$

August $31 \ldots \ldots \ldots \ldots \ldots \ldots . \ldots . \ldots 49$

September $28 \ldots \ldots \ldots \ldots \ldots \ldots \ldots .558$

October $26 \ldots \ldots \ldots \ldots \ldots \ldots \ldots .614$

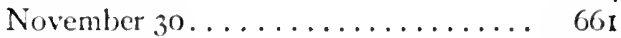

December $21 \ldots \ldots \ldots \ldots \ldots \ldots \ldots, 746$

1918

January $25 \ldots \ldots \ldots \ldots \ldots \ldots \ldots 793$

February 2 1.............. 877

March 29................. 852

April $26 \ldots \ldots \ldots \ldots \ldots \ldots \ldots .624$

May $3 \ldots \ldots \ldots \ldots \ldots \ldots \ldots . . . . . .655$

June $28 \ldots \ldots \ldots \ldots \ldots \ldots . . \ldots 97$

July $26 \ldots \ldots \ldots \ldots \ldots \ldots \ldots \ldots$ 910

August $30 \ldots \ldots \ldots \ldots \ldots \ldots \ldots$. . . . . . 6

September $27 \ldots \ldots \ldots \ldots \ldots \ldots$ 1,161

October $25 \ldots \ldots \ldots \ldots \ldots \ldots \ldots$. 1,184

November $29 \ldots \ldots \ldots \ldots \ldots \ldots$. . 1,216

To a greater and greater extent the country's gold was being drawn into the hands of the reserve agents where, according to the amendment of June 21,1917 , it would be counted as part of the reserve banks' 40 per cent required reserve. By this process other gold in the reserve banks' vaults was released to serve as the reserve for deposit grants to member banks.

${ }^{1}$ See Reports of the Federal Reserve Board, 1917, p. 47; 1918, pp. 97, 98. 
The effect of the discount operations upon reserve banks' ratio of cash reserve to net deposits and notes is next indicated:

Ratio of Total Casil Reserves to Net Deposits and Federal RESERve NOTES ${ }^{*}$

I9I 7

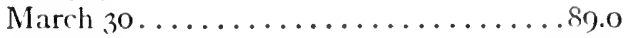

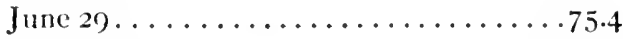

August $3 \ldots \ldots \ldots \ldots \ldots \ldots \ldots \ldots$. . . . .

November $2 \ldots \ldots \ldots \ldots \ldots \ldots \ldots$. . . . . . . . .

December $28 \ldots \ldots \ldots \ldots \ldots \ldots \ldots .6 .6 .6$ 191 8

February 21 ................66.0

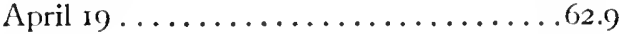

May 3 ז ....................62.0

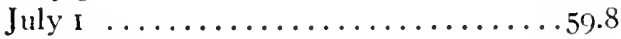

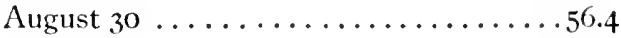

November $22 \ldots \ldots \ldots \ldots \ldots \ldots \ldots . \ldots .50 .5$

Great, however, as was this reduction in the reserve ratio, it would have been much greater had it not been for the new accretions of gold by the reserve banks. On April 5-6, I9I 7, for instance, the total gold holdings of reserve banks (gold in vaults plus gold with foreign agencies plus Gold Settlement Fund plus gold deposited with Federal Reserve agents as cover for the notes) was $\$ 943,552,000$. On November I5, I9 I 8 , this total was $\$ 2,056,777$. Credit and currency expansion were so great and so rapid that the huge surplus reserves of April 6, I9I7, would have fallen far short of meeting the demands. Only the attraction of gold from the general circulation enabled reserve banks to maintain a favorible ratio. As it was, the reserve ratio fell approximately forty per cent in little more than a year and a half of hustilities.

Let us next ascertain the effect of the war upon the operations of member banks. Between May I, I9I7, and

× See Reports of the Federal Reserve Board, 1917, p. 15; 1918, pp. 9, 10. 
November I, I918, demand deposits of all national banks responding to the Comptroller's call ${ }^{x}$ increased from $\$ 7,6$ I 8 , o I I, o00 to $\$ 8,640,8$ I 8,000 , or more than a billion dollars. Time deposits increased in the same period by a sum approaching $\$ 300,000,000$. Loans and discounts advanced in the same time from $\$ 8,751,679,000$ to $\$ 10,096,940,000$, or approximately one and a quarter billion dollars. Total resources displayed a gain of $\$ 3,676,97$ I, 000.

In view, however, of the huge increase in reserve bank operations some surprise may be evoked because the increase of member bank advances was not even more large. Deposits with reserve banks comprise the legal reserves for member banks. Each dollar of deposits with a reserve bank forms the legal minimum reserve for many dollars of its own deposits. The advances of reserve banks furnish the basis for a several-fold expansion in member bank operations.

We must recall the effect, however, of the amendment of June 2I, I9I7, which required the deposit of all reserve money with reserve banks. As country banks transferred their funds from their city reserve agents to the reserve banks, the deposits of the city reserve agents diminished and those of the reserve banks increased. For instance, the condition of reserve banks prior to the amendment is indicated by the weekly statement of June 22, 1917. On that date the reserve banks due-to-members account was $\$ 806,209,000$. The final transfer of reserves was completed July 20, 1917. On this date the reserve account of members had increased to \$1,164,995. Nore than $\$ 350,000,000$ of reserve bank deposits represented the

\footnotetext{
' Sie Comptroller's Report, 1917, vol. 1, p. 35; 1918, vol. 1, p. 16. Fisures fur May, 1917, are for $7,5 \%$ banks. Those for Novemler 1, 1918, are for 7,754 banks.
} 
shifting of reserves to reserve banks. So far as the increase of Federal Reserve note issues is concerned, it has been shown that they represented in large measure the substitution of notes for gold in the general circulation.

An increasing volume of currency and credit indicates one of several results. ${ }^{x}$ First, it may point to a higher degree of industrial and business activity. If the general level of prices remains unchanged, greater production and more numerous exchanges necessitate an increased circulation of money. Secondly, the increased circulation may indicate, not greater economic activity, but rather a higher price level at which exchanges take place. Third, the enlarged circulation may indicate changes either in the amount of productivity or in the general level of prices. Let us next endeavor to ascertain in which direction the effect was felt most largely.

The figures of the United States Bureau of Labor Statistics ${ }^{2}$ show an enormous rise of wholesale prices in this period. Considering 1913 as a base year the index number of wholesale prices for all commodities advanced as follows:

I9I 7

April...... I72
May ...... I 82
June..... I 85
July...... I 86
August.... I 85
September .. I 83
October ... I 8 I
November . I 83
December... I 82
I91 8

January.... I 85

February ....186

March ..... 887

April....... 190

May....... I90

June ........ 193

July ....... 198

August....202

September . .207

October ....204

November . .206

- No account is taken here of changes in the rate of turnover of money. Undoubtedly money was becoming more efficient in this period. The Gold Settlement Fund and the Federal Reserve Clearing System, for instance, lessened enormously the amount of money required to effect inter-bank balances. To the extent that the efficiency of money was increasing, we have another explanation of the rise in commodity prices.

${ }^{2}$ Bulletin No. 269, July, 1920, pp. 16-19 
In the field of retail prices the movement for the same period is indicated by the following index numbers of the Bureau of Labor Statistics representing twenty-two articles of food: ${ }^{\mathbf{}}$

\begin{tabular}{|c|c|}
\hline \multicolumn{2}{|c|}{$1913=1$} \\
\hline 1917 & 1918 \\
\hline April....... 445 & January .... I 60 \\
\hline May....... I5I & February ... I6I \\
\hline June . . . . I52 & March .. .. I54 \\
\hline July.......146 & April ......154 \\
\hline August . . . . I 49 & May....... I5s \\
\hline September. . I 53 & June... . . . I62 \\
\hline October & July . . . . .167 \\
\hline November . . I 55 & August .....I7 I \\
\hline December . . I57 & September .178 \\
\hline & October .... I 8 I \\
\hline & November .. I 83 \\
\hline
\end{tabular}

Both wholesale and retail prices displayed an exceptionally large advance. Let us next endeavor to ascertain whether the volume of trade increased in anything like a similar degree. Figures in this field cannot be accepted with so much confidence because the increase in business activity is bound up with that of increased prices. Bank clearings, for instance, may show no more the effect of increasing trade activity than the heightened price level at which exchanges of goods and services were made. This problem of entangling prices from the volume of business has been most successfully attempted, however, in statistics relating to the production of raw materials. According to figures contributed by Professor Wesley C. Mitchell, the following index numbers represent changes in the production of ninety commodities. In order to eliminate the effect of the change in the price level the value of all commodities is figured on the basis of 1917 prices. $^{2}$

- Bulletin No. 27o, February, 1921, p. 27.

Cf. Bulletin, April 1, 1919, p, 337. 
Index Number of all Commoitties

Yearly Production Times 1917 Prices

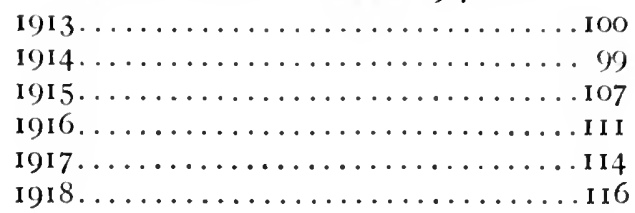

These figures would seem to indicate that the withdrawal of labor to the field and camp almost overcame the effect of speeding up inclustry by resort to the devices of more complete employment, longer hours for labor, and the bonus system. The year I9I 8 shows only a slight increase over I9I 7. While the field of production statistics has received little attention until recently these results agree sufficiently closely for our purposes with those of other statisticians. Walter W. Stewart, for instance, using 1913 as the equivalent of 100 , shows the advance in 1918 over I9I7 to be one point (125-124). ${ }^{x}$

These facts show that the enlarged media of exchange correlates more closely with the rise of commodity prices than with increasing trade activity. We may next inquire as to the causal relationship between the increase in the media of exchange and the advance in commodity prices.

It is clear that the bond method of war finance resulted in an increasing money demand for goods. The part played by the banks in furnishing funds for bond purchases was such as to supply the means whereby the Government and the consuming public were brought into sharp competition one with the other. The Government was given credit not previously in existence, and this credit was employed for the purchase of labor and materials. So far as these became more scarce relative to the demands

"Cf. WV. IV. Stewart, "An Index Number of Production," American Economic Review, March, 1921, p. 68. 
DEVELOPMENT, MAY, I9I7, TO NOV. II, I9I8 28I

for them, the individual could secure them only by offering higher prices. It is true, however, that this was not the result of all types of Government bond purchases. If the individual purchased the Government bonds out of savings, no enlarged money demand for goods was made possible. Credit previously possessed by the subscriber was transferred to the Government. To the extent that this enabled the Government to offer money for goods, the individual's demand must be lessened. The Government merely took the place of the individual and the conditions of demand were not greatly altered.

But in many cases, war bond subscriptions resulted in something more than the mere transfer of existing bank credit from the bond purchaser to the Government. If the bond was bought by a bank, bank credit was given to the Government, but loans to the bank's customers need not be reduced. In case of a shortage of loanable funds, the bank had merely to call upon the reserve bank for a discount. In such a situation customers of the bank retained the funds they possessed before, and the Government entered the market with new credit to bid for goods.

The same results followed when the individual hypothecated his bonds with his bank as collateral for a loan, or purchased the bond out of money loaned by the bank. In these cases the individual's bank account was not correspondingly lessened by the bond purchase, and the net result of the transaction was to furnish the Government with dollars in such a way as not to lessen the bond purchaser's ability to offer dollars for goods. Finally, if the bond was used itself as a medium of exchange, it operated in much the same way as Government paper money.

The effect, however, of an enlarged monetary demand for goods need not necessarily result in higher prices. The increased demand may make possible production on a 
larger scale in such a way as to lessen per-unit expenses. To the extent that competition prevailed in the industry, lower production costs would be reflected in lower prices. Slight reflection, however, is required to indicate that this could not have been the usual result. In order to remove labor from peace to war industries, the wage scale necessarily had to be advanced. New standards of labor remuneration were thus established which unionized labor insisted upon realizing elscwhere. The tremendous demand for war materials made it necessary throughout the industrial field to extend production to the relatively inefficient plant. There was much work for the marginal concern. These factors seem to have more than counterbalanced the cconomies occasionally realized of large-scale production. Enlarged demand necessitated greater perunit expenses and accordingly higher prices. The only means of preventing such a result would have been to employ a method of war finance whereby advances of bank credit to the Government could be made only by lessening the public's command over dollars of credit or currency. The bond method obviously could not do this.

It is no part of the purpose of the writer to elaborate the objectionable features of the war-time price advance. The difficulties created, particularly for the unorganized worker, the bondholder, public utilities, endowed universities and hospitals, in general for the recipients of relatively fixed incomes, have been sufficiently elaborated in popular discussion. It is fully understood, also, how the destruction of old standards of fair prices, standards which were the crystallization of past competitive conditions, made it virtually impossible for the consuming public to keep a close check upon the profiteer. Labor disturbances also and the consequent interference with war materials' production were frequently attributable to the worker's 
DEVELOPMENT, MAY, 1917, TO NOV. I1, I918 283 unwillingness to submit to a reduction in the real value of his wage. Altogether, price inflation enabled a small class of society to levy undeserved tribute upon the other classes. Profound and permanent changes in the social and economic structure of society were the inevitable results. Most of these changes, affecting extremely harshly the middle classes and the organized worker, were not such as to render easier the preservation of real democracy in this country's future.

But the writer would prefer to emphasize two special aspects of the war-time price increase. In the first place, it rendered more difficult, if not impossible, the satisfactory solution of many international as well as of domestic post-war financial problems. Secondly, it retarded the speedy mobilization of this country's material and manpower for war.

It was clear to careful observers that our post-war requirements would be such as to necessitate easy money and liberal credits. The release of soldiers from field and camp and the cessation of work in the munitions' factories would demand the rapid return of these men into industry. To fail to secure their speedy reëntry must mean unemployment, discontent, and unrest. Accordingly, the post-war banking policy must be one of easy money rates and liberal credits. The banks should offer this stimulus to industry after the war.

Every dollar of credit expansion during the war rendered this post-war relief more difficult, however. Even despite the sudden cessation of hostilities the war-time advance was such as to render a further increase almost unendurable to the non-entrepreneurial classes of society. As it was, prices got further out of line with each other, and the inevitable readjustment was rendered more serious. But if the war-time price advance could have 
been retarded, a slight post-war increase, made possible by offer of liberal bank credits, could have been withstood with comparative ease.

The price increase of the war period rendered more difficult also our post-war position as the world's banker. Despite the enormous advances to Europe made in the days following the signing of the armistice, there seems no doubt in the mind of the writer that we fell far short of the demands upon us. This should not be construed as meaning that we did not loan Europe sufficient sums for nonproductive purposes. On the contrary, the writer feels that one of our greatest mistakes of the reconstruction days was our failure to restrict Europe's purchases to the goods needed for her industrial revival. We permitted her to dissipate her credit in the purchase of luxuries and consumption goods until the point arrived when her purchases must necessarily be restricted. Rather suddenly, American export industries lost their European market. There need have been no such loss of this foreign market. If Europe's purchases could have been confined to machinery, necessary raw materials, production goods in general, her ability to continue to buy from us need not have been impaired. The resuscitation of her industries would have enabled her in time to purchase our goods through offer of the credits established throughout the world by sale of the products of her revived industries. But as it was, Europe used up her credit quickly without restoring her earning power. We could have afforded to loan far more to her had the credits been used for wise reconstruction purposes. The delay of reconstruction in Europe helped to usher in this country's depression of I920-2I.

But was price inflation necessary to win the war? Were not bond subscriptions necessary to furnish the dollars 
DEVELOPMENT, MAY, I9I7, TO NOV. II, I9I 8285

required by speedy mobilization and rapid war preparation? Were not cheap rediscount rates necessary to enable banks to guarantee their customers the funds for their bond subscriptions? Could the twenty-odd billions of dollars have been obtained other than by a policy of inflation?

Nobody would argue that any such colossal sum of money could have been obtained in any other way. If our total national annual income prior to the war was no more than fifty billions of dollars, for which estimate there is reputable statistical authority, nothing like fifteen or twenty billions a year could have been obtained by taxation or borrowing from the public's savings. Our economic life was not so ordered as to permit the devotion of one half or one third our total income for war purposes. The only means of securing such a stupendous sum lay in direct or indirect bank advances. But under this method each dollar bought less than would the dollars contributed under a tax or buy-a-bond-out-of-savings-only programme.

To secure the speediest mobilization of our war resources, the funds for military purposes should have been obtained from the existing volume of money and credit. The lessening of funds expendable for peace goods would have hastened the transfer of labor from the industries of peace to the industries of war. The most rapid shifting could be compelled only by lessening that portion of our income stream customarily spent for civil goods. Credit and currency expansion delayed the process of war mobilization.

Since the war, when more leisurely reflection is possible, there has been an increasing disposition to accept these views. But these views, we are informed, represent judgment ascertained after instead of before the fact. They indicate only the hindsight of the parlor observer. In order 
to make clear the writer's position in this matter, he would like to quote from an article prepared by him in the winter of $1917-18$ in the midst of our warlike preparations: ${ }^{x}$

To what purposes, then, should the reserve banks' surplus gold be put? Should it be used at the present time to enable member banks to increase their loans to the business public, or should it be carefully husbanded to meet post-bellum requirements? Now is the time when this question of policy must be met squarely. The Board that controls the largest surplus stock of gold the country has ever held surely ought not to content itself with mere day-to-day decisions. Let the maximum amount of credit be extended to-day and heightened commodity prices will render this gold unavailable for later purposes. More bank loans, and consequently more gold, will be needed to finance the same volume of transactions. Deflation can take place only slowly and gradually and with resultant depression to business.

In the minds of the great majority of the people the Board can make but one choice. We are reminded that the present need for funds exceeds that of any previous period, that the gravity of the war situation demands that every possible dollar be used to meet existing requirements regardless of any opportunities to come. National defense, we are told, supersedes all future trade advantages. By liberal offer of its credit the Board should quicken, therefore, the course of present industry. If inflated prices result, these must be accepted as part of our sacrifice to the cause of democracy.

Each day, however, the fallacy of this view grows more obvious. It is becoming clear that the production of war supplies is fundamentally not a problem of securing dollars, but rather one of commandeering labor and materials. The real problem of war finance is to shift labor and equipment with the least possible delay from the unessential to the necessary war industries. No matter what financial programme is adopted, it is clear that only by restricting the operations of the non-war industries can there be the largest possible increase in the production of military

${ }^{x}$ Cf. H. L. Reed, "Credit Expansion under the Federal Reserve," A merican Economic Review, June, 1918, pp. 270-82. 
supplies. The stream of purchasing power that ordinarily flows to the one must in large measure be transferred to the other. The quickest transition can take place, not by increasing the total volume of bank dollars, but by diverting dollars from former fields of expenditures. The funds for financing war industries and activities should be obtained in largest part from the existing volume of money and credit.

In the last analysis the real gain from economizing our gold does not arise from an internal expansion of credit. By virtue of price adjustment domestic industry can accommodate itself either to a large or to a small volume of bank credit. The advantage of refining our credit system results rather from foreigntrade operations. To support our credit structure with less gold releases the surplus for foreign purchases, virtually enabling us to obtain the products of foreign industry without the expenditure of labor or the sacrifice of material on our part. To the extent, therefore, that foreign countries are not in a position to sell to us to-day, our surplus gold should be retained for postbellum needs. In the measure that we use this gold at the present time to support domestic loans, and thereby inflate the general level of prices, we lose our power to reap the final and ultimate gains.

Inflation is sometimes defended on the ground that rising prices have a stimulating effect upon industry. So much accustomed are we to think in terms of dollars, rather than in terms of their purchasing power, that an increase of money incomes may exert a favorable psychological effect upon business and labor. As David Hume once described the effect of the gold and silver discoveries of the sixteenth century: ${ }^{x}$

Accordingly we find that, in every kingdom in to which money begins to flow in greater abundance than formerly, everything takes a new face: labor and industry gain life: the merchant becomes more enterprising, the manufacturer more diligent and skillful and even the farmer follows his plow with greater alacrity and attention.

* Essays, Moral, Political and Literary. 
This argument was scarcely applicable, however, to the period of our participation in the war. Our financial problem was as much to repress the industries of peace as to stimulate the industries of war. The rising prices stimulated the unnecessary quite as much as the necessary war industries. Rapid preparation for war could come only by withdrawing capital from the industries of peace at the same time that funds were being made available for those of war.

There is no doubt but that the general public was unprepared for heroic financial measures. Our patriotism is a curious thing. It is fit that men be conscripted to die upon the firing line. It is not fit that there be conscription of the civilian's income, not his capital, to equip the soldier. Yet those who resist taxation, the logical method of transferring funds from civil to war expenditures, are the stuff out of which war heroes are made! We scem to prefer to bear the financial burden of war indirectly, rather than directly, in the form of higher living costs. But this sort of a sacrifice is most inequitably imposed upon the people of society.

Would it have been possible, however, to educate the public to the fact that the bond method, in the same manner as any other, involves a real burden which the public cannot shift to another generation by borrowing from its own people? In the last analysis the economic burden of war consists in the using up of commodities and human services for purposes of destruction, thus lessening the volume of production for civil uses. Selling bonds to its citizens does not mean the shifting of the burden to a future generation. An internal debt is not a burden for a people as a whole. To the extent that some are taxed to pay the interest and the principal of the bonds, others benefit by receiving these taxes in the form of bond inter- 
DEVELOPMENT, MAY, I917, TO NOV. II, I9I8 289

est and principal repayment. If bonds are not in the next generation a burden upon the people as a whole, there could be no shifting of the burden from the generation which witnessed the conflict.

It may be that it would have been impossible to secure general confirmation of these simple economic principles by the ordinary processes of education and propaganda. But if so great attention had not been drawn to the virtually unlimited supply of dollars in the reserve bank reservoirs, the necessity of higher taxes and more restrictive rationing methods would have become apparent much more early. Gradually we should have seen that a modern world war necessitates financial as well as military conscription. But the part played by our public authorities was such as to deaden our perception of these facts. We were encouraged to buy bonds on such terms as inevitably to create price inflation. Individual subscribers were offered funds indirectly obtained from the Federal Reserve; banks virtually were informed that they would be protected by the Federal Reserve banks against oversubscription on their own part or on the part of their customers. Everything possible was done to lull instead of to arouse a spirit of critical analysis by the public.

But what was the responsibility of the Federal Reserve administration in all this? Should the Federal Reserve Board have refused to coöperate with the Treasury? Should it have based its rediscount policy upon general banking and financial considerations alone and have ignored the Government's fiscal programme? Should the reserve banks have ignored the bond issues in the formation of their discount policies?

Only slight consideration is required to indicate the undesirability of any hostile attitude. During time of war the various govermmental agencies cannot refuse mutual 
coöperation. They cannot work at cross-purposes. Congress had sanctioned the bond method of war finance, and the treasury undoubtedly acted in accordance with the general point of view in recommending the "low interest" policy. When Congress enacted the Federal Reserve Act it provided specifically for ex-officio membership on the Board of the Secretary of the Treasury and the Comptroller of the Currency. Was not this the expression of its desire that there be close coöperation between the Treasury and the reserve banking authorities?

From the standpoint of political expediency it would have been extremely unwise for the Reserve Board to have refused full coöperation with the Treasury. From the time of Andrew Jackson the public has accepted the dictum that the management of a central banking system must consider itself a servant of public authority. During the World War it could not have established for itself an independent position.

Whatever responsibility can be placed on the shoulders of the Board, therefore, can only be those resulting from its encouragement of an unsound financial policy. The final question to be investigated, therefore, is whether or not the Board's counsel was such as to encourage inflationary tendencies.

There is no doubt regarding the Board's position in this matter. Throughout the war it preached the doctrine of conservation of credit as well as of goods. To quote from its official pronouncements in the January I, I9I8, Bulletin: ${ }^{\mathbf{x}}$

Events are, however, every day making it clearer that the conservation of our financial strength is not of itself sufficient to ensure the successful financing of the war. The financing of the war is only in part a money problem; in very large part

I Pages 2, 3 . 
DEVELOPMENT, MAY, I9I7, TO NOV. II, I9I8 29I

it is an economic problem - a problem of conserving the economic as well as the financial strength of the Nation. ...;

Nobody should, therefore, consume goods except to the extent that their consumption is necessary to maintain health and vigor;

Let the public realize that it is more respectable in such war times as confront us to be seen in old clothes than in new ones. Let the banks tell the people of their communities and their authorities, the mayors and governors, that this is not the time for cities to be spending money on public works. . . . ;

... it must nevertheless be our constant concern to keep every dangerous tendency in the banking situation under control and particularly to retard the too rapid expansion of banking credit. ...

The effectiveness of such implorations may well be questioned. Spending cannot be lessened while the means of spending increase. Nevertheless, the Board's record, during this period, was clear. Whatever the evils of the easy-money policy of war finance the responsibility cannot be laid at its doors. The fault was that of the Treasury, of Congress, and of the people. So infrequently does war occur that the requirements of successful war finance are not generally understood. No nation ever taxed itself sufficiently highly during a great war. Any other policy must be inflationary. During the Civil IVar the inflation was a matter of greenback issues. During the World War it was a matter of note issue and bank credit expansion. But throughout this period the reserve banks were merely financial instruments through which the Treasury endeavored to accomplish its aims. 


\section{CHAPTER XV}

FEDERAL RESERVE DEVELOPMENT, NOVEMBER I2, 1918, TO MAY, 1920

\section{THE PERIOD OF POST-WAR CREDIT EXPANSION}

AFTER the signing of the armistice, the industrial outlook was extremely uncertain. It is true that most of the longtime forces seemed to point toward the early resumption of general prosperity. The labor and the materials that had been utilized for war purposes would now be available to supply our normal wants, and, moreover, the cessation of hostilities enabled industries to be freed shortly from a host of restrictive measures. Gradually embargoes upon certain articles of export were removed, the list of prohibited imports reduced, and the priority rules established under the rationing policy of the War Industries Board abandoned. Shipping was increasing in quantity, building and construction were no longer to be discouraged by public authority, and the war restrictions relating to the securing of investment capital for private enterprise were repealed. With these fetters removed, it appeared that the general economic welfare soon would improve. ${ }^{\mathbf{x}}$

Expressions of confidence frequently overlooked, however, the fact that in our existing economic society industrial activity depends upon the volition and the appraisals of the entrepreneur. If he does not feel the situation ripe with profit-making possibilities, industrial stagnation is our lot. Instead of demobilization increasing the more complete utilization of our labor force, it might mean

"Cf. H. L. Reed, "The Industrial Outlook," Journal of Political Economy, April, 1919, pp. 225-40 
merely the recruiting of the army of the unemployed. The essential question at the close of I9I9 was whether or not industrial and financial conditions were such as to arouse enthusiasm on the part of the entrepreneur.

In very many respects the situation was cloudy. Money wages of the laborer had increased far above their pre-war level and it did not appear that they could be reduced quickly. Organized labor appeared determined to hold what it considered to be the gains of the war period, to insist upon the prevailing wage scale even though commodity prices should fall to a lower level. It is true that the manner in which wages were increased was frequently such as to offer hopes of speedy reduction. The elimination of extra hours of labor would remove the necessity of paying high rates for the products of the hours of greatest fatigue. With the suspension of work in the war industries the employer's bargaining power would be still further increased. A strike could take place only in a situation where many unemployed would be looking on. The return of soldiers, moreover, would enable the employer to take his pick and select only the fit. During the war, labor costs were high, not merely because of the high money wages, but also because employment had to be offered to the most inefficient of the labor group. Nevertheless, there was the likelihood that the life of the soldier had been such as to unfit him for steady work in monotonous tasks. War necessarily creates a spirit of unrest and independence, not consistent with strict industrial discipline.

As to finding markets for industry's products there appeared to be much less uncertainty. The economies of the war period left many demands unsatisfied. Work on the roads, on buildings, on capital equipment of various sorts, could not continue to be neglected. In the course of time the Government demand for investment funds would 
relax and enable a part of society's income stream to be redevoted to the purchase of neglected goods and services.

In one way it was particularly fortunate that a large portion of our soldiers did their fighting three thousand miles from the United States, and that many months elapsed before all of them could be returned home. Industry was not required to plan for the immediate absorption of all of these millions. Demobilization began with certain special units in this country and was extended gradually. As the men first discharged worked their way into industry, their own wages would help to create the demand for the production of other goods. By the time the divisions from the battle front returned, industry might be revived sufficiently to offer them general employment.

From the banking standpoint the situation was somewhat more hopeful. At the close of hostilities the reserve ratio of the reserve banks was approximately fifty per cent. It would appear that this would be sufficient to guarantee ample funds for a moderate volume of new financing. It was true that the expenditures of the war had not terminated. One new bond issue was yet to be offered to the public, and it was plain that for some time the Treasury must appear in the loan market as a bidder for investment capital. There were also certain possibilities of a considerable drain of gold from the reserve bank reservoirs. During the war the embargo upon gold prevented us from balancing our indebtednesses by shipments of the money metal, particularly to the neutral countries of Europe and to certain nations of the Orient. Unpaid balances as well as new indebtedness might create a heavy demand for this purpose. It might be that our inability to collect gold from the warring nations of Europe might subject us to a loss of gold even though our general trade 
balance was favorable. But all in all the sudden termination of hostilities left our banks in fairly good shape.

It was in the matter of prices, however, that the greatest uncertainty existed. There was grave doubt everywhere as to whether the war level could be maintained. Undoubtedly the common prediction was that the removal of war conditions would destroy the cause of the high prices, and that in a short period the restoration of production would bring about their decline. It is true some difficulty was experienced in explaining how there could be enhanced production in a situation of tumbling prices. Would not weakening prices destroy the entrepreneurial incentive to productive activity? The general feeling, nevertheless, seemed to be that the war level was an abnormal level, and that normal conditions would mean the return of the pre-war level.

Such, for instance, was the prediction of Mr. B. M. Anderson. To quote from his argument: ${ }^{x}$

The belief that there will be a drastic drop in prices is based on obvious conditions. With a vast volume of labor rapidly being discharged from munition factories the world over to resume the production of nomal supplies; with steel, copper, coal, shipping and other essentials released; with 50,000,000 soldiers returning to farms and factories, there will be an immense increase in the volume of goods available for civilian consumption. Prices should fall, even before this actual transformation is carried far, because wholesale markets commonly. forecast impending changes.

It must be admitted that the price movement, shortly after the armistice, tended to confirm these views. The wholesale price index of the Bureau of Labor Statistics showed for December, I9I8, a decline in the clothing,

s "When War Ends and Prices Drop," Economic World, November 23, 1918, p. 727 . 
metal, and chemicals groups. ${ }^{*}$ Both in January and in February the index for all commolities fell somewhat. The first two months of I9I9, moreover, displayed a decline in the index number of retail food prices. ${ }^{2}$

In the belief that a continuous price decline was inevitable, certain projects were launched for the purpose of hastening the return to the "rock-bottom" level, the level at which industry could figure upon the immediate revival of activity. No positive achievements resulted from these projects, but there was no disposition to impose harsh restrictions upon industry. The Federal Reserve banks held their rates low. For January, I919, the average rate charged on all paper discounted by the reserve banks was 4. I 8 per cent and for February 4 .I 4 per cent. ${ }^{3}$

In a short time, however, it appeared that predictions of price decline were not to be fulfilled. Both in March and in April the all commodities wholesale index of the Bureau of Labor Statistics showed a slight increase, and the expected 'difficulties of finding employment for the returned soldiers did not seem insurmountable. Undoubtedly most observers were amazed at the rapidity with which industry adjusted itself to the new conditions. It is probable that not one tenth as much discussion was heard of the problems of reconstruction as had been anticipated. The May, I9I9, Bulletin noted that price recessions had not been as rapid as predicted. It stated $:^{4}$

What is now happening seems to indicate that business will, after a period of initial readjustment in prices, proceed upon a level not far removed from that established during the war, leaving the question as to the ultimate level of prices to the future and to more slowly acting forces.

I See Bulletin No. 269, July, 1920, pp. 16-19.

' See Bureau of Labor Statistics, Bulletin No. 270, February, 1921, p. 27. The index numbers are made up of the prices of twenty-t wo articles of food.

3 Report of the liederal Reserve I3oard, 1919, p. 176 .

+ Page $+1 \mathbf{I}$. 
Various were the explanations which were offered for this unexpected firmness of prices. For one, the foreign demand for our products proved much stronger than anticipated. Also during the war, the prices of many commodities had been held artificially low by the pricefixing activities of Government agencies. When the restrictions were removed, supply and demand conditions were such as to exert a tendency for these prices to move to a higher point. On the part of entrepreneurial management there was undoubtedly also a recognition of the fact that the time was not opportune for a conflict with labor, that since labor insisted upon a high level of money wages it would be best for the time being to proceed upon the assumption that wages were not to be reduced. Wages could be put in proper relation to other prices by permitting the general level to advance. But whatever the correct explanation, it was recognized generally by the spring of 1919 that the period of price uncertainty was over and that the industrial barometer pointed toward increasing activity.

The financial events of the following year are now well understood in their general outlines. The country was to experience a rise in prices, an expansion of currency and credit, and a boom in industrial and speculative activity which exceeded by far even that of the war period. This is indicated by the following facts:

April 25, 1919, the reserve account of member banks with reserve banks was $\$ 1,664,320,000$. April 23, 1920, it was $\$ 1,859,062,000$, a gain of nearly $\$ 200,000,000$. In the same periol the circulation of Federal Reserve notes increased more than $\$ 500,000,000$ and earning assets over $\$ 800,000,000$. On May 12, 1919, the Comptroller's reports show loans and discounts for 7773 national banks to be $\$ 9,904,821,000$. May 4, I920, 7990 national banks pos- 
sessed loans and discounts of $\$ 12,288,582,000$. 'This was a gain of more than two and a third million dollars. The activity on the stock exchanges, the boom in security prices, the rise of call-money rates exceeded past precedent. In the field of wholesale prices the movement was as follows:

Bureau of Labor Statistics' Index Numbers of IVholesale Prices for All Commodities. Base $1913=100$

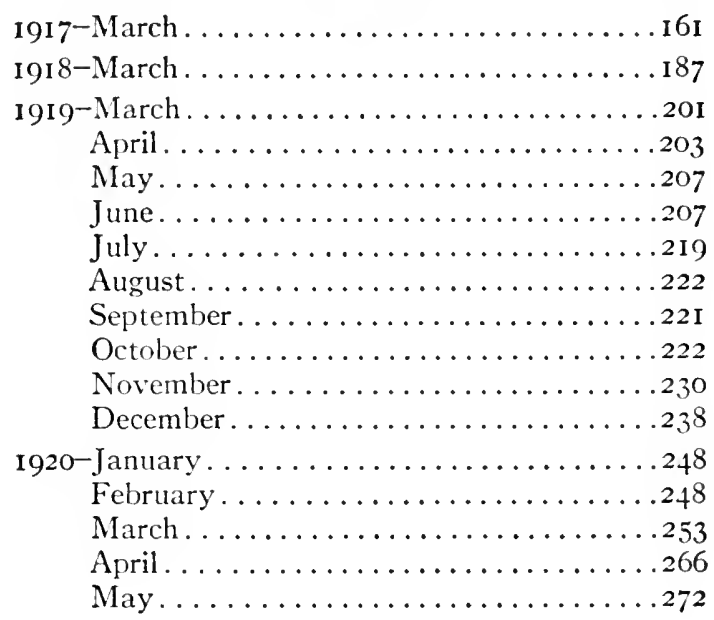

In view of the fact that this currency and credit expansion was so great as to cause the reserve ratio to fall from 7 I.7 per cent on May 2, I9I9, to 43 per cent on May 7 , ' I920, and that on many occasions the New York Reserve Bank's ratio ${ }^{x}$ was on the margin of falling below the legal

'A slight change in the method of computing reserve banks' reserve ratio was introduced February 12, 1920. Regarding this the January, 1920, Bulletin (p. 3) states: "Beginning with February 12, 1920, the reserve to be carried by Federal Reserve Banks against deposits will be computed against immediately available deposits only. Items on the liability side whose availability is deferred and uncollected items on the resource side of the bank statement will be disregarded in determining the liability upon which reserve is computed. This action will tend to apply a more severe standard of computation, especially in the case of those banks which have been carrying a relatively large float." 
minimum, some astonishment may be evoked because the reserve administration permitted this enormous expansion of credit and currency. It should be emphasized that this expansion rendered possible an unexampled ${ }^{\mathrm{I}}$ price increase in time of peace. It had generally been expected that the post-war cra would witness an attempt to return to pre-war conditions. ${ }^{2}$ As stated in the Bulletin for March, r919: ${ }^{3}$

The era of inflated prices maintained by aid of legislation or by Government administrative action thus draws to a close, and the aim to be sought is not that of perpetuating war conditions, but that of returning to a stable footing upon the terms and conditions that would be just and fair to all concerned. There is much agreement with the Secretary of the Treasury in his statement that the readjustment must begin with a reduction in the cost of living to the consumer, sorely tried as the latter has been by the great inflation of prices and the additions made to his living costs in many directions.

It should be kept in mind, furthermore, that in the latter part of I9I9 many speculative excesses were commonly attributed to the rapid growth in the volume of bank credit.

Explanation of the credit policy of the reserve administration may be attempted by considering the following suggestions:

First, the short-time fiscal requirements of the Government were such as to cause the Treasury to demand easy money rates.

Secondly, there was the fear that higher rates would work a hardship upon the holders of the war bonds by depressing further the market price of their securities. Thirdly, it was believed that easy credits were neces-

Unexampled in this country since the greenback era.

- As stated in the previous chapter, the writer does not believe this would have been good policy.

3 Page I9I. 
sary to enable industry to readjust itself quickly to the new conditions.

Fourthly, there was a failure to perceive the correct relation between expanding credits and rising prices in a period of great industrial activity. The theory was apparently accepted that prices were determined by other forces than the volume of currency and credit.

Fifthly, a restriction of credits would have been politically unpopular. The public does not understand the necessity of restraint in the manufacture of bank credit. Its complaints are directed most largely against the results of an unduly rapid expansion and not against the expansion itself.

Sixthly, there was much doubt as to the effectiveness of the weapons possessed by reserve banks to curb continuous increases in the reserve banks. In no previous period of Federal Reserve operation had restrictions been $\mathrm{em}$ ployed vigorously. Precedent and experience were lacking.

In regard to the short-time fiscal requirements of the Treasury, it will be recalled that the Victory notes were issued in the spring of 1919, and that in the succeeding months the Treasury continued to meet its current requirements by selling low-interest-bearing short-time certificates. To have increased rediscount rates on paper collateraled by these issues would have rendered their sale difficult. It will always be a grave question as to whether the continuation of the low-interest policy was justified. Despite the depreciation of the dollar, it is probable that such a policy was to the immediate advantage of the Treasury. Since a large portion of the Government's disbursements were fixed in terms of dollars, its expenditures did not increase proportionately with the decline in the value of the dollar.

Whether or not there was warrant for subordinating 
banking considerations to Treasury requirements is another matter. But as the situation developed it was not until after January, 1920, when the Treasury gave up its policy of floating certificates at abnormally low rates, that considerations of banking policy became the controlling factor.

But Government finance exerted its influence in other guise than in the Treasury's short-term requirements. It was understood that the market quotations of war bonds must be further depressed if rediscount rates were increased. If member banks could not rediscount paper collateraled by war bonds, the banks could not carry the subscribers without loss. Was not the Government morally obligated to protect those who had heeded its call to borrow and buy bonds?

Thorough analysis seems to indicate that there was no possible manner in which the interests of these bondholders could be protected fully. Bond prices could be upheld only by a policy of inflation. But inflation meant a clecline in the purchasing power of the dollars realized by the sale of the bonds. What if they did sell near par? The proceeds would purchase less and less either in other securities or in goods, the greater the depreciation in the purchasing power of the dollar. In other words, the sacrifice of the bond-buyer in purchasing low interest securities must mean loss to him. No policy of inflating to keep money rates low could avoid this loss. Only an ease in the money market, determined freely and without artificial control, could aid him.

Those connected with the Treasury have not hesitated, however, to defend its policy on the ground of war necessity. To quote from R. C. Leffingwell, Assistant Secretary of the Treasury: ${ }^{\mathrm{I}}$

- See American Economic Revicw, March, 1921, pP. 30-36. 
During the whole period of the war any attempt of the Federal Reserve Board to control credit through rates would have been futile. The Treasury would have had to meet any rate they made at home, and the federal reserve bank rate could have no effect upon the international situation, because the international movements of goods, gold, and capital was controlled by foreign governments or our own for the purposes of the war. The adoption of a "dear money" policy during the war, with a view to preventing inflation would have failed of that purpose unless it had been carried to such an extreme as to bring about such conditions in war time as exist to-day, in which case we should have lost the war and would have had to inflate afterwards in order to pay the indemnity which Germany would have imposed upon us.

If Leffingwell means by this that a higher rate on bonds would not have enabled the Government to obtain many more dollars from the bond subscriber, we may express agreement. To a very large extent considerations of interest and income were ignored by the bond-buyer in the making of his subscription and a higher rate might not have attracted greater purchases. No matter what the rate, the national income was not large enough to permit a large portion of the subscriptions to be made from savings. Banks were obliged to advance a large part of the funds, expecting individual subscribers to take them up at a later date. But to the extent that these considerations are true, we have another argument against relying upon borrowing as the chief means of securing war revenues. At an earlier date heavier taxation would have aided the process of speedy mobilization and would have confined the financial disturbances more largely to the period of hostilities.

But to continue Leffingwell's statement:

After the war was over in the fighting sense, it went right on in the Treasury sense. We reached the peak of expenditures in 
the three months, November and December, i9 8 , and January, 19I9. We spent two billion dollars a month. That was as much as the First Liberty Loan each month. Since armistice day this Government has paid out as much as before armistice day, twenty billions before and twenty billions after. The gross debt of the Government on armistice day was eighteen billions. Nine months later it was twenty-six and a half billions. While the Government debt was mounting thus, the same condition continued which had existed during the period of active warfare. It was no more practicable to exercise control of credit by the use of dear money than it had been before. Indeed, it was less practicable, because the enthusiasm, devotion and self-sacrifice of the American people while war was on vanished over night with the signing of the armistice. The bills did not get paid any easier, but a good deal harder, because the Germans had capitulated.

\section{And further:}

Though something may be said for the view that in the latter part of I9I9 there might have been a somewhat earlier and greater advance in rates on commercial paper and in the open market buying rates for acceptances, my own judgment is that this is a question of detail rather than of substance, and that the effort to make money really dear before January, I920, when the Government was first able to reduce its floating debt to manageable amounts and maturities, would have risked more than it could have hoped to gain.

The undesirability of any pronounced increase in rediscount rates, as well as in the rates borne by the Treasury certificates in the post-war period, seems clear to the writer. But the matter of a slight increase at a date prior to the fall of I9I9 appears to be something more than a mere matter of detail. While the enhanced cost of bank credit in and of itself might not have been of great effect upon industry it would have furnished the most forcible statement possible of the reserve administration's discontent with the existing situation, and of its purpose to 
restrict credits as soon as the condition of the Treasury made such action possible. It might have prevented so thin a stretching of the speculative bubble. Despite the warnings of the Federal Reserve Board and of the reserve bank directorates, very many came to look upon the reserve system in the wrong light. For the first time in the period of reserve operation, rediscounting began to be considered generally as primarily a means of securing funds for profit-making opportunities. As stated by the Board in its April, I9 I9, Bulletin: ${ }^{\mathbf{1}}$

Already some well-managed member banks are showing in their statements the extent to which they are in debt to Federal Reserve Banks. It has been the opinion of the Board that the borrowing of member banks at Federal Reserve Banks might very easily be carried to excess, the loans being placed there primarily for the purpose of profit and not for any more general public or fundamental object. In a general letter to banks, issued on November I9, (I918), and referred to in the Federal Reserve Bulletin for December, the Board took occasion to caution member banks which it was thought were in some danger of overdoing their rediscounting, that the purpose of such rediscount operations was not primarily that of assisting the member institutions which placed the rediscount to obtain the funds for further profitable operations, but was rather to be determined upon the basis of general banking advantage or upon that of relief for banks which found themselves hard pressed or were suffering from reductions in reserve account.

The writer does not believe, however, that such warnings as these were interpreted very seriously. IVithout positive action in the form of rate increases they seem to have been regarded merely as indicative of the Board's viewpoint, a viewpoint not likely to warrant coercive measures. The crisis of 1920-2I was due to many causes. One of these was excessive commodity speculation which

'Page 3Ir. 
was fanned by the belief that credits would continue to remain cheap. The only way to dissipate this belief would have been to raise rates before the bull movement had spread far.

An increase of a half per cent or so on the 'Treasury's short-term borrowings would not of itself have been an important consideration. A few millions of extra charges would have heen a negligible consideration compared with the losses suffered by this country in the industrial collapse of I920-2I. Part of these losses might have been prevented by initiating at an earlier date a policy of rate increases.

Strengthening, however, the view that rates should be kept low was the desire to enable industry to readjust itself quickly to new conditions. It was a matter of supplying the stimulus of easy credits. Not until the summer of I9I9 was there manifested any strong disposition to look at the matter from the standpoint of the consumer's interests. In the general demand for lower living costs which followed the Railway Brotherhoods' insistence that either their wages should be increased or the cost of living lowered, there was manifested a general inclination on the part of those prominent in the reserve administration to lay the emphasis upon the necessity of wage revision rather than upon a reduction in prices. Mr. A. C. Miller, a member of the Federal Reserve Board, declared, for instance, that

Some mechanism by which wages may promptly be adjusted to changes in the cost of living must be accepted as an essential part of the American wage system.

He did not state what should be done to relieve the recipient of a fixed income, the bondholder, the bank depositor, the endowed university or hospital.

- Cf. Bulletin, October 1, 1919, p. 915. 
Prior to the cost-of-living controversy in the summer of I9I9 there had been no clear statement of the Board's position regarding the relation of an increasing volume of currency to the general level of prices. But on August 8, 1919, in a letter replying to an inquiry of the Senate Committee of Banking and Currency, Governor Harding expressed his views on this question. To quote a brief extract from Governor Harding's statement: ${ }^{\mathbf{x}}$

The difficulty, indeed the impossibility, of keeping in circulation an excessive volume of Federal Reserve notes should be understood. . . . They are issued only as need for them develops, and as they become redundant in any locality they are returned to the Treasury at Washington or to a Federal Reserve bank for redemption. Thus there cannot be at any time more Federal Reserve notes in circulation than the needs of the country at the present level of prices require.

In other words, the volume of note issues depends upon the height of prices. Instead of the volume of currency determining the general level of prices, it is a matter of the level of prices determining the height of the price level.

Because the increase in circulation of notes had exceeded the increased grants of book credit to member banks, Harding's communication dealt almost entirely with note issues. It appears to the writer, however, that the same position must be taken regarding deposit credits granted by member banks. The underlying theory of Federal Reserve note issues was that the notes should be emitted under regulations more similar to those governing deposits. In reality the nature of the note and the deposit are identical. They both represent ways by which banks may create credit or credit money. It is true that the note possesses a greater circulation power and is needed by banks to avoid losing reserve money on occasions when

* Bulletin, August I, 1919, p. 699 ff. 
there is a drain on counter money. But so far as their effect on prices is concerned, and that is the question now under discussion, both must be regarded as part of the general circulating medium.

If this theory be true, that the volume of the circulating medium depends upon the height of prices, the reserve administration's responsibility would appear to be lessened considerably. It never could issue more Federal Reserve notes than the "needs of the country at the present level of prices require." Its policy in creating credits or currency could never be attacked. Prices are determined by other factors and other causes, without direct regard to the acts of the reserve administration.

Since this theory, if accepted, would relieve the Board of many attacks and adverse criticisms, it is not surprising that the Board was inclined to emphasize it. But is it true?

Viewed superficially, the theory appears to be correct. Every business man knows that there are countless transactions in which prices are agreed upon first, and that the bank credit to satisfy the purchaser's indebtedness is granted later. In such situations it appears that the height of prices, independently fixed, determines the volume of credit later to be created. But what led our buyer let us say a retail dealer, to agree to pay such and such a price? The principal consideration was whether so high a price must be paid to get the goods, and whether the demand of consumers would be sufficiently strong to enable him to unload at a profit. It requires but a moment's analysis to demonstrate that both of these factors are subject to influence by the banks in their grants of credit to the business pulblic.

Why did our dealer agree to pay the stipulated price? Obviously, because the seller of the goods could obtain a 
favorable price elsewhere. What enabled other dealers to bid up prices for the goods? Obviously, it was a matter of the general volume of currency or credit at their command. In the creation of this credit, the banks elsewhere played their part in determining the strength of the outside competitive demand. If they had been more illiberal in their advances, our buyer could not have been compelled to offer so high a price.

It is also clear that banks' advances help to determine the terms on which the dealer can unload his goods. The credit first advanced to him in the making of a purchase is gradually diffused throughout all classes in socicty. From the hands of the retailer it is passed successively, perhaps, into the hands of the wholesaler, wage-earner, and landowner. It thus helps to determine the intensity of the money demand of consumers for the goods.

But even if the effect of this advance of credit upon supply and demand conditions elsewhere is ignored, it is clear that the price our dealer will pay will be influenced by his knowledge of the bank's attitude toward his requests for credit. In making credit available for the dealer, the bank exerted an influence upon the money demand for the goods.

The writer does not mean to argue that there are no limitations upon banks' ability to affect the price level by the liberality of their credit grants. Under certain conditions, particularly those of declining confidence in the future stability of the market, banks' discount policies may have little effect on market prices. Bank credit cannot be forced upon a reluctant business community. But in a situation of increasing business confidence and rising markets, of business activity and commodity speculation, such a situation in fact as that of the summer and fall of 1919, banks did hold the key to the situation. They fur- 
nished the credits which enabled buyers to shove up prices in their eager desire to get goods quickly.

As indicated in the previous chapter, ${ }^{\mathrm{x}}$ however, an enlarged money demand does not always bear as its principal fruit higher prices. The enlarged money demand may enable the scalc of production to be increased on terms of lower per-unit costs. 'To quote from the writer's statement $\therefore$ in another connection: ${ }^{2}$

Suppose the situation is one in which additional labor and materials are easily available, that new orders need not necessitate enlargements of plants or changes in equipment. Larger production may create possibilities of economy in the amount of overhead or fixed charges allocated to each unit of output. If, under these circumstances, retailers are stimulated to a reasonable extent by information that the required credit will be forthcoming, prices are not necessarily disturbed. As a matter of fact they may even be lowered in that the retailers' orders may make possible production under conditions of greater efficiency. It may no longer be a matter of setting up greater dollar competition for the limited quantity of goods, but rather using more dollars to affect the transfer of more goods. Easy and abundant credit may thus affect either the level of prices or the volume of production or both. Undoubtedly the situation in which prices and production are both affected outnumber the cases in which abundant credit works upon the one alone. But as to which is most influenced an a priori answer is not possible. It all depends on the industrial situation.

It is unnecesiary to present evidence regarding the nature of the industrial situation in the period following the spring of 19 I9). It was a boom period of the most pronounced character. Little good unemployed labor was to be hat, goots and materials could be acepured only hy bifleing against competitors who were also short in sup)-

x See supra, pp. $281,282$.

"Cf. H. L. Reed, "A Stabilized Dollar," American Econumic Revienc, March, 1921, Pp. 91-93. 
plies, extra production could be had only by expensive enlargements of buildings and changes in machinery. Production could not be speeded up so rapidly as credits were increasing. Speculation, and not social production, absorbed a large portion of the volume of bank credit, and speculation tended to accelerate the rapidity of price advance. This was a situation in which bank credit played its part in increasing the buying competition and in diffusing throughout the business community the buying power in terms of dollars, on the basis of which prices were fixed.

Simple as is this principle, it is extremcly difficult to secure assent to it by the general public. No matter what the industrial situation, restrictions of credit grants are always unpopular. It is always asserted that the banks are handicapping productive enterprise. It is not understood that when the productive engine is running at full speed more fuel will not aid it. It is not clear that credit granted to this enterprise in a boom period may not add to the total volume of production. It is forgotten that too great activity soon brings the inevitable reaction by encouraging unsound enterprise. Money is confused with wealth, and the public's first reaction is always to side with the proponents of easy money.

Expressive of the popular point of view the following quotation might be made from a letter of a New Jersey, banker, E. C. Stokes, written in the summer of 1920 , to Senator Owen, commending the latter on his protest at the Board's belated policy in raising its discount rates: ${ }^{\mathrm{x}}$

Increased credit is not the cause of high prices. Increased credit is the result of high prices and is necessary because prices are high. If the industries and business of the land could be assured of more and cheaper credit, production would be

${ }^{x}$ See Commercial and Financial Chronicle, June 5, 1920, pp. 2341-45. 
encouraged, and with an increase of production prices would fall. With assurance of the proper amount of credit at reasinable rates, intensive production would follow and prices woulkl be cheaper, even without a reduction in wages. This prosluetion however, will never be undertaken by the manufacturer or " by the farmer if he thinks his loans are going to be called or curtailed and he himself forced into bankruptcy because of inability to carry his enterprise to completion.

There then follow illustrations of the very many projects which it would be desirable to encourage. Not a sentence in the entire letter displayed an inkling of an understancling of where the labor and materials for these vast new projects could be found. There was no recognition of the fact that unduly rapid credit grants at one period cannot accelerate continuously the speed of the industrial machine. All that was understood was that ecrnomic activity increases in the early periods of cheap and al)undant credit. But price adjustment to new and higher levels makes the advantage of easy money only temporary. Only continued increases in bank advances enable the boom to go on. There has to be a stop sometime. It is desirable that the brake be put on before the situation has become ripe for a violent reaction. The industrial situation must be contemplated from a long- as well as from a short-time point of view.

It must be admitted, however, that such demancls for unlimited credits as those just quoted from the letter of Mr. Stokes are the natural fruit of the price theory, formulated by the Governor of the Federal Reserve Board, that prices determine the volume of advances the banks must make.

But this was not all. Reserve banks deal mainly with member banks, and there was much doubt as to the effect of rediscount rate increases upon the operations of 
the latter. The spread between the prevailing commercial rate and the reserve rate appeared to be so great as to make rediscounting profitable despite moderate rediscount rate increases. These rate increases could only be moderate because of the Treasury's low-interest-bearing flotations. It is true that a higher rate could have been, and as a matter of fact was, decreed for non-war paper. But this meant merely that member banks offered war instead of commercial paper in their rediscount applications. There was much doubt, moreover, as to how efficiently a rate increase would work. There was not sufficient past experience to guide the reserve administration in the formation of its discount policy. Expression was given to this difficulty by the following statement of the October, I919, Bulletin: ${ }^{\mathrm{I}}$

The extent to which Federal Reserve Bank rates may normally be expected to be "effective," in the sense in which that term is used in Continental Europe, still remains to be determined. Our experience under the Federal Reserve system is too brief to enable definite conclusions to be drawn with reference to this matter. It seems doubtful, however, whether, for a long time to come and taking the country as a whole, there will be any such close connection of Federal Reserve Bank rates with the volume of credit in use as was to be noted, for example, in pre-war days in England, the home of central banking. Our nearest approach to an effective Federal Reserve Bank rate was reached in the closing months of the year 1916.

This matter will be discussed more completely in the following chapter. But sufficient explanation should have been offered regarding the hesitation of the Board to insist upon higher rates in the early part of the industrial boom of I9I9.

The situation, however, soon became such as to demand restrictive measures. The loss of gold to foreign countries,

1 Page 911. 
together with the great increase of advances to member banks and note issues resulted in considerable worry regarding the adequacy of the reserve ratio." 'These facts are expressed by the following figures:

\begin{tabular}{|c|c|c|c|}
\hline DAte & $\begin{array}{l}\text { TOTAL GOLD } \\
\text { RESERVES OF } \\
\text { RESERVE BANKS }\end{array}$ & $\begin{array}{l}\text { Total Net Deposits } \\
\text { AND FEDIRAL Reserve } \\
\text { Note LIABILITIES }\end{array}$ & \begin{tabular}{|} 
RATHO OF C.ISHI RL- \\
SERVES IO NET I DE- \\
POSITS ANI FEDERAL \\
RESERVE NOTE LIA- \\
BILITIES
\end{tabular} \\
\hline \multicolumn{4}{|c|}{ OOO'S OMITTED } \\
\hline 1919 & & & \\
\hline June $6 . . . \ldots$ & $\$ 2,201,804$ & $\$ 4,225,155$ & 53.7 \\
\hline July $3 \ldots \ldots$. & $2,128,946$ & $4,324,351$ & 50.8 \\
\hline August I . . . . & $2,088,475$ & $4,273,00 \mathrm{I}$ & 50.5 \\
\hline September 5 .. & $2,067,052$ & $4,235,8 \mathrm{I} 4$ & 50.4 \\
\hline October $3 \ldots$. & $2,1,35,282$ & $4,434,452$ & 49.7 \\
\hline November $7 \ldots$ & $2, \mathrm{~J} 19,565$ & $4,677,269$ & 46.8 \\
\hline December 26. & $2,078,4,32$ & $4.762,116$ & 44.8 \\
\hline
\end{tabular}

Meanwhile also the dates were approaching upon which member banks would no longer be obligated to carry the bond subscriber. Most banks had agreed to make oneyear loans to subscribers for the Fourth Liberty Loan and six months' loans to purchasers of the Victory notes. According to such arrangements these loans would expire in October and November. Although the Treasury's shortterm floating debt increased throughout the summer of I919, it reached its peak on August 31, I9I9, and it became probable that the 'Treasury's requirements would no longer be so controlling a factor. As stated in the October I, I9I9, Bulletin:2

The disappearance of the Treasury from the long-term loan market and the rapid reduction in its requirements for shortterm accommodations foreshadows the approach of the time when the financial operations of the Government will cease to be the important factor in shaping Reserve Bank policies which they have been, and Federal Reserve Bank rates once more

From January I, I9I), to Nowember Io, I9 in (the approximate date of the rate increases), the excess of gold exports over gold imports was $\$ 226,089,000$.

- L'agéno. 
will be fixed solely "with a view of accommodating commerce and business."

By the fall of 1919 , moreover, it was becoming clear that new creations of currency and credits were no longer exerting a stimulating effect upon the country's productive activities. Much worry was occasioned also because of the undesirable quality of paper in member banks' portfolios. In particular, the percentage of renewals was far too large. What theory had predicted confidently at an earlier date was now being exemplified by results. The country's productive mechanism could not accommodate too big a load. In the early part of November, accordingly, rates were increased slightly at all reserve banks as a means of indicating the determination to raise rates still higher if the reserve ratio fell further. On December II, after the autumnal demand for funds had subsided, another slight rate increase was sanctioned by the Board.

The reluctance of the reserve administration to adopt these measures is evidenced by the fact that the increase was preceded by many warnings. For instance, on June Io, I919, the Board made public the following letter which had been sent out to all Federal Reserve agents: ${ }^{\mathbf{x}}$

The Federal Reserve Board is concerned over the existing tendency toward excessive speculation, and while ordinarily this could be corrected by an advance in discount rates at the Federal Reserve Banks, it is not practicable to apply this check because of Government financing. By far the larger part of the invested assets of Federal Reserve banks consists of paper secured by Government obligations, and the Board is anxious to get some information on which it can form an estimate as to the extent of member bank borrowings on Government collateral made for purposes other than for carrying customers who have purchased Liberty bonds on account, or other than for purely commercial purposes.

- Cf. Bulletin, December I, 1919, p. I 108. 
DEVELOPMENT,.NOV. 12, 1918, TO MAY, 1920315

The rate increases of 1919 were continued in the early months of 1920. In January, after the Treasury had raised the rate on short-term certificates to $43 / 4$ per cent, the Board approved a similar increase on paper secured by these certificates.

Toward the end of January, however, the rate on paper secured by Liberty bonds and Victory notes was advanced to $51 / 2$ per cent and the rates on all classes of commercial paper, including trade acceptances and agricultural and live-stock paper, to 6 per cent. ${ }^{x}$

Except in the financial centers of the country these increased rates had little real effect in checking the continuous expansion of credits. By the end of April, 1920, the total earning assets of reserve banks were considerably larger than in December, 1919. But it had become evident that the rate of credit and currency increase was falling and that the speculative boom was collapsing. With the spring of 1920 , one stage in the post-war business cycle was drawing to a close.

- Report of the Federal Reserve Board, 1920, p. 57. 


\section{CHAPTER XVI}

FEDERAL RESERVE DEVELOPMENT, MAY, 1920, TO THE PRESENT TIME

\section{THE PERIOD OF BUSINESS READJUSTMENT}

IT is no part of the writer's purpose to measure statistically the relative influence of the various factors which coöperated to create the industrial reaction of 1920-21. Such a task would far exceed the limits of the present chapter. It will suffice for our plans to indicate the instability of the industrial situation in the spring of 1920 and to state briefly the causes of the subsequent depression.

In the opinion of many the post-war boom had carried us to a new and permanently higher level of prices. A very large part of the world's total gold supply had come to the United States, and this gold, in large measure deposited in the vaults of the Federal Reserve banks, had furnished the basis for the creation of a much larger volume of deposits and note issues than the country ever before had witnessed. Relatively to commodities the media of exchange had been greatly increased. The international trade situation, moreover, was not such as to indicate any early redistribution of our gold among the nations of Europe. Consequently, a larger volume of bank deposit and note currency could be supported without endangering in the immediate future the maintenance of the gold standard. There were no indications, furthermore, that our banking administration would endeavor to deflate for the purpose of restoring the old price level. All the evidence pointed toward the acceptance of the belief that attempts to correct financial maladjustments should 
assume the form of such devices as wage advances and railway rate increases. The rises in rediscount rates of the preceding period clearly had been initiated only as a means of preserving the reserve ratio and of preventing the inclusion in bank portfolios of too large a quantity of unsound paper.

Nevertheless, the memories of a lower price level were still vivid to a large portion of the people. It is true there had been no indication of a sudden return to the I9 I 3 level. But any temporary decline in the market would be interpreted generally as the beginning of the process of reëstablishing "normality" in prices. In this situation a voluntary lowering of prices to relieve congestion in the warehouses or on the shelves of merchants might not have the effect of increasing buying suddenly. If this viewpoint should be adopted generally, orders might be cancelled in large volume, the demand for labor lessened, and the reduction in money wages restrict the ability of the public to purchase goods. All that was required to set in motion a continuously accelerating buyers' strike was evidence of temporary weakness in the market.

The unhealthiness of the situation was due also to the rapidity of the price advance. All the weaknesses which normally develop in a period of prosperity had been accentuated by the amazing speed in the upward movement of the market. Commodity and security speculation had been overdone grossly; labor was losing its discipline; the assumption of unwise ventures had been encouraged by artificial cheapness of money; bank reserves were falling rapidly. On the New York Stock Exchange the shares traded in during 1919 were almost fourfold as great as in I9I3, and bond activity was multiplied almost sevenfold. Total bank clearings for the Nation were approximately two and a half times as great in 19 ig as in I9I3. The 
Comptroller's reports showed that net deposits of national bankis had increased from 7.I billions of dollars on October 21, I9I3, to I2.2 billions on September 12, I9I9.

It is inevitable in such eras that values and operations become based not solely upon confidence that former growth will be maintained, but that the rate of acceleration will be continued. Present speculation rests upon future anticipations. But by the spring of 1920 it was evident that, while the limit of their resources had not been reached, banks were genuinely worried as to their ability to finance new projects. The maturities of paper were growing and the percentage of renewals increasing. Considerations of public finance pointed also toward higher rates in the near future. In 1920 the Treasury advanced the rates on six months' certificates to $53 / 4$ per cent and to 6 per cent for twelve months' maturities. The Treasury was no longer to dominate the reserve banks so completely in the formation of discount policies. The money market was no longer to be kept so low by artificial measures. The true rate of interest was to be permitted to emerge. Coinciclentally with the rise in rates the member banks were being cautioned against the granting of unessential credits. Further credit expansion was possible, but the rate of past growth must fall.

Had the physical volume of production been less large in 1919 and 1920 the date of the reaction might have been postponed. But the volume of production, particularly in the first half of I920, was enormous. The Government's crop forecasts for 1920 were exceedingly favorable, presaging one of the best years on record. Mills and factories were thought generally to be working close to maximum capacity. But railroads found themselves unequal to the strain thrown upon them. The reports of the American Railroad Association disclosed a net shortage of cars three 
of the last four months of 1919 and for every month of the first half-year of 1920 . Shipments which might have been dispatched on advantageous terms were delayed until an enormous quantity of goods accumulated in the centers of production. It required not much of a shock to induce a general order of price cutting in order to move goods.

It had been apparent for some time that the international trade situation was growing more and more unhealthy. The balance of trade for I9I9 was over four billions of dollars in our favor, exceeding all past records. But in each of the first four months in 1920 the balance in our favor was much less than that for 1919. In several markets 1920 was to witness a sharp price break. After the early collapse of the silk market in Japan, there were rapid declines in the prices of sugar, coffee, and other products of Cuba and Latin-American countries. The Federal Reserve Board's international wholesale price index showed a price decline ${ }^{\mathrm{x}}$ in April for Japan, and a May decline for the United Kingdom, France, Italy, and Japan. In June, 1920, the Bureau of Labor Statistics' index number for wholesale prices of all commodities in the United States was to show the first recession experienced since the early part of I919. The accumulation of goods created by the inability of the railroads to furnish sufficient cars and the crash in foreign markets may have been the immediate factors causing the first severe shock to business confidence. Once this check had been felt, it was impossible to prevent the manifestation of all the weaknesses in the industrial system which have been developing gradually in the preceding boom period. The buyers' strike became soon, not a matter of volition, but of downright necessity. The reduction in money incomes created less demand for labor's services.

'Sec Keport of the Federal Reserve Board for 1920, p. 7 . 
A large part of the Federal Rescrve administration's policy during the crisis may be told statistically. The following figures depict the situation regarding changes in the reserve ratio, note issues, member banks' reserve account, total earning assets, and rates of discount on ninety-day paper.

\begin{tabular}{|c|c|c|c|c|c|c|}
\hline \multirow[t]{2}{*}{ DATE } & $\begin{array}{c}\text { Total } \\
\text { EARNING } \\
\text { ASSETS }\end{array}$ & $\begin{array}{c}\text { FEDERAL } \\
\text { RESERVE } \\
\text { NOTES IN } \\
\text { CIRCULA- } \\
\text { TION }\end{array}$ & $\begin{array}{c}\text { ' } \\
\text { MEMBER } \\
\text { BANKS' } \\
\text { RESERVE } \\
\text { ACCOUNT }\end{array}$ & $\begin{array}{c}\text { CASH } \\
\text { RESERVE } \\
\text { RATIO }\end{array}$ & $\begin{array}{c}\text { DISCOUNT } \\
\text { RATE ON } \\
\text { 90-DAY } \\
\text { PAPER IN } \\
\text { EFFET } \\
\text { FIRST DAY } \\
\text { OF THE } \\
\text { MONTH }{ }^{1}\end{array}$ & $\begin{array}{l}\text { DISCOUNT } \\
\text { RATE ON } \\
\text { 90-DAY } \\
\text { PAPER } \\
\text { SECURED BY } \\
\text { LIBERTY } \\
\text { BOND AND } \\
\text { VICIORY } \\
\text { NOTES THB } \\
\text { FIRST DAY } \\
\text { OF THE } \\
\text { MONTHI } \\
\end{array}$ \\
\hline & \multicolumn{2}{|c|}{ In billions of dollars } & \multicolumn{4}{|c|}{ In percentage } \\
\hline I920 & & & & & & \\
\hline $\operatorname{May} 7 \ldots$ & $3.2 \mathrm{I}$ & 3.09 & $1.8 \mathrm{I}$ & $42.7 \%$ & $6 \%$ & $5.6 \%$ \\
\hline June $4 \ldots$ & 3.27 & 3.12 & I.85 & 42.5 & 6.25 & 5.7 \\
\hline July $2 \ldots$. & 3.27 & 3.16 & I. 87 & 42.8 & 6.3 & 5.76 \\
\hline Aug. $6 \ldots$... & 3.18 & 3.14 & I. $8 \mathrm{I}$ & 44.0 & 6.3 & 5.77 \\
\hline Sept. $3 \ldots$. & $3 \cdot 36$ & 3.24 & 1.82 & 42.5 & 6.3 & 5.77 \\
\hline Oct. I.... & $3 \cdot 30$ & $3 \cdot 30$ & I. 77 & 43.7 & 6.3 & $5.8 \mathrm{I}$ \\
\hline Nov. $5 \ldots$. & 3.42 & 3.35 & 1.77 & 43.0 & 6.4 & $5.8 \mathrm{I}$ \\
\hline Dec. $3 \ldots$ & 3.33 & $3 \cdot 3 \mathrm{I}$ & 1.76 & 44.1 & 6.4 & $5.8 \mathrm{I}$ \\
\hline I92I & & & & & & \\
\hline Jan. $7 \ldots$. & 3.13 & 3.27 & I.79 & 46.4 & 6.4 & $5.8 \mathrm{I}$ \\
\hline Feb. $4 \ldots$ & 2.88 & 3.07 & 1.74 & $49 \cdot 3$ & 6.4 & $5.8 \mathrm{I}$ \\
\hline March $4 \ldots$ & 2.78 & 3.04 & 1.70 & 50.8 & 6.5 & 5.95 \\
\hline April I.... & $2.6 \mathrm{I}$ & 2.90 & 1. 67 & 52.4 & 6.5 & 5.95 \\
\hline May $4 . .$. & 2.42 & 2.82 & I.67 & $55 \cdot 3$ & 6.4 & 5.95 \\
\hline June I .... & 2.26 & 2.75 & I.65 & $57 \cdot 4$ & 6. I9 & 5.95 \\
\hline July $6 \ldots$. & 2.09 & 2.67 & 1.65 & 60.0 & 6.08 & 5.95 \\
\hline Aug. $3 \ldots$. & I.90 & 2.53 & 1.61 & 63.7 & 5.87 & 5.83 \\
\hline Sept. 7... & I.79 & $2.5 \mathrm{I}$ & 1.63 & 66.2 & 5.79 & 5.74 \\
\hline Oct. $5 \ldots$ & 1.66 & 2.48 & I. $6 \mathrm{I}$ & 69.0 & 5.75 & 5.70 \\
\hline Nov. $2 . .$. & I. 54 & 2.40 & 1.65 & 71.0 & 5.66 & 5.66 \\
\hline Dec. $28 \ldots$ & 1.53 & 2.44 & I. 66 & $7 \mathrm{I} .1$ & 5.04 & 5.04 \\
\hline
\end{tabular}

1 Average for the twelve Districts.

These facts show that there was no contraction of cur- 
rency or credits enforced by Federal Reserve authority during the depression. The combined Federal Reserve note circulation and member banks' reserve account at the close of 1920 exceeded that of the spring of the year. It should be kept in mind that these advances were maintained in volume despite the drop in prices. Since lower prices lessen the need for credits, the growth in reserve bank advances was in reality much larger than the figures indicate. The wholesale price index of the Bureau of Labor Statistics, which was 272 in May, 1920 , had fallen to 189 in December of the same year. So willing were the reserve authorities to employ their resources for the legitimate requirements of member banks that it was not until after the beginning of the new year that the reserve ratio began to move to a point commanding confidence. Discount rates increased until the spring of I92I, but they were never unusually high relatively to market rates. As a matter of fact they followed rather than preceled the movement of money rates in the financial centers. Until the summer of 1921 rates on four to six months' prime commercial paper were close to eight per cent in the New York market.

Recovery from the crisis was slow and uncertain. Bond and stock prices began to move upward sharply in the early summer of 1921. But security price movements precede usually the revival of business confidence. It was not until the close of I92 I that the volume of new securities issued became such as to indicate any general return of confidence. Nevertheless, at the close of the year statistics of failures portrayed greater mortality than at any preceding date of the crisis.

The public was somewhat slow to perceive the extreme severity of the depression. Had there been no Federal Reserve system to prevent credit contraction, a financial 
panic of unexampled dimensions might easily have occurred. What the reserve system has done has been to draw out the period during which liquidation took place. But so far-reaching were the maladjustments which had developed in the preceding boom period that no sudden revival of confidence was possible. Too many prices got out of line with each other. Relatively to other prices, agricultural commoditics fell too far. As a consequence the agricultural demand for manufactured products continues low. Unless, furthermore, adequate machinery is developed for supplying Europe with production goods for restoration purposes, we cannot count on the foreign demand. Building, however, is rapidly developing into the dimensions of a boom, and in this lies the germ of speedy resumption of industrial activity.

With the clearing of the industrial situation it is especially desirable that Federal Reserve policy for the future be formulated more definitely. In all the eight years of Federal Reserve operation there has not been a period when the administration was free to make a comprehensive statement of the relation of the reserve banks to other parts of the financial mechanism. Until 1917 the problem was that of acquainting member banks with the reserve banks' facilities and of getting into the market at a time when member banks' reserves were high. From I9I7 to the armistice the requirements of war or of war preparation were dominant considerations. In the post-war expansion period the Treasury's needs were such as to cause purely banking requirements to be subordinated. In the period of depression the inevitable charges of undue severity made the situation inopportune for any clear statement of future discount policy. But in the coming period of industrial revival it is important that the essentials of rediscount control be developed. If this be not done, 
industrial activity again may attain unhealthy dimensions thus breeding the forces of another reaction. The late depression has shown that, while the reserve system may serve to prevent sudden liquidation and thus to lessen the acuteness of the shock, it cannot prevent unhealthy tendencies from asserting themselves in the form of destroyed business confidence.

At the present time the surplus reserves of the reserve banks are enormous. December 28, $192 \mathbf{I}$, the total reserves of the reserve banks were 2992.2 millions of dollars. This would form a forty per cent reserve for $7+80$ millions of note issues and deposit credits granted to member banks. Assuming member banks require a fifteen per cent counter money and legal reserve combined, this $7+80$ millions would enable them to advance 49,866 millions to the business public. Since the total net deposits of national banks on the Comptroller's report for September 6, I92I, was 10.8 billions of dollars, an approximate fourfold expansion in national member banks' advances is possible. Here lie opportunities for inflation never before possessed in like measure by any banking system. If any large part of this new credit supply is utilized suddenly, the price level must react correspondingly. It is not possible that our physical volume of production be increased in any such measure. Too rapid credit expansion must mean price inflation. It, therefore, is more essential now than ever before that definite principles of credit control be formulated. Day-to-day considerations cannot be permitted to govern unless the reserve banks are to become mere engines of inflation.

Until business confidence is restored there is no danger of unduly rapid creations of currency or credits. New issues would become redundant. But in the next era of business revival it will be necessary to know when the 
endeavor should be made by reserve banks to restrict credit increases. Let us consider accordingly the wisclom and practicability of the following bases of credit control:

(a) Regard should be had primarily for the reserve ratios of reserve banks. In other words, reserve banks should take into account the same sort of considerations which guide the loan policies of member banks. They should concern themselves primarily with their ability to meet their obligations.

(b) Credit advances of reserve banks should be regulated in such a manner as to maintain the price level as stable as possible.

(c) Credit advances should be regulated in such a manner as to maintain the productive activities of the Nation as great as possible. Regard should be had, however, for long rather than for short-time considerations.

(d) Since certain excesses, such as impaired liquidity, appear whenever industrial activity is fanned by excessive credit grants, restriction should be begun whenever these evils become more than ordinarily prominent.

Let us consider these possibilities in turn.

There appears to be much to offer for a policy of utilizing the reserve ratio as a guide for rediscount policy. In Sprague's words: ${ }^{\mathbf{r}}$

It is definite and obvious. Public opinion may be expected to support the always unwelcome policy of credit restraint when that policy is enforced by a depleted reserve. It is unhappily very doubtful whether the public would have been reconciled to the advance in rates made last spring [1920] if the reserve banks had had, let us say, a rese:ve ratio of 55 per cent, and yet, all other things being the same, an advance in rates would have been no less desirable.

"Cf.O. M. IV. Sprague, "The Discount Policy of the FederalReserve Banks, ' American Economic Review, March, I921, pp. 27, 28. 


\section{Further:}

There is no substitute for the reserve ratio which possesses its peculiar virtues of simplicity and definiteness.

It is extremely unfortunate, therefore, that the situation frequently may (levelop to necessitate credit restriction even at a time when reserves are increasing. In a season of very active trade, payment of foreign balances might compel the shipment of gold to this country. In that situation our bank reserves would increase, yet the possibilities of too rapid expansion might then exist. The quantity of gold in the reserves is a product of more or less fortuitous circumstance and bears no necessary relation to the credit requirements of business.

There is also much to say for making price stability the test. The injustices of a rapilly changing price level are now recognized fully. Since bank credit is our most important medium of exchange, its volume should be regulated in such a way as to ensure a fair degree of price-stability over a course of time. It is also true that a chief evil created in a boom period is the throwing out of adjustment of various prices. The greater the rise in the general level, the greater the probability that their normal relationship will be disturbed. To maintain the level of prices stable, therefore, might accomplish much in the way of climinating periodic disturbances in business.

It is doubtful, however, whether public opinion would ever sanction the use of such a guide. As indicated previously, the people of this country lean innately toward the side of easy money. Particularly true is this of seasons of activity. The matter of legal authority for such a test is also doubtful. Mr. A. C. Miller, of the Federal Reserve Board, has stated: ${ }^{x}$

" Federal Reserve I'olicy," A merican Econonic Review, June, 1921, 1. 193. 
There is now no warrant in the statute under which the felcral reserve banks are organized for undertaking to regulate their credit operations on any such basis. The economic logic of the Federal Reserve aet is clearly predicated upon the theory that the federal reserve banks shall be operated with regard to reserve ratios, and "rates be fixed with a view of accommodating commerce and business." It would imply a very latitudinarian construction of the term "accommodating commerce and business" for the Federal Reserve Board and the federal reserve banks to adopt the "observed effects of credit on prices" as their rule of action in the future. There is not, however, the slightest reason for supposing that such a procedure on the part of the federal reserve banks would be viewed with public approval. Quite the contrary. Public sentiment in the United States is, and always has been, highly sensitive in matters of credit control, and precisely, among other reasons, because of the bearing that such control has, or is believed to have upon the movement of prices.

Mr. Miller's efforts accordingly are designed to alter the reserve machinery in such a way as to make it more safe to depend upon the use of reserve ratios as a guide.

Mr. R. C. Leffingwell's vigorous statement on this matter is as follows: ${ }^{\mathrm{I}}$

I share Dr. Miller's objection to Professor Sprague's suggestion that federal reserve rates should be determined by price movements. There is no man, or group of men, to whom the American people will, or should, accord the right to determine whether they shall be prosperous or miserable, whether thay shall have high prices or low prices, whether they shall have good times or bad times. The day Professor Sprague's suggestion is adopted by the Federal Reserve Board marks the end of the federal reserve system. It would be absurd for the Federal Reserve Board to ignore price movements as symptoms of the general situation, but it cannot base its discount policy upon them.

Both Miller and Leffingwell admit that the reserve I "The Discount Policy of the Federal Reserve Banks," American Economic Review March, 1921, p. 35. 
ratio alone cannot be an adequate guide. But in order to enable it to be utilized with effectiveness, they make certain proposals designed to remove the dangers connected with its use. Leffingwell suggests ${ }^{1}$ that

If the reserve gets big enough to be embarrassing, the best cure for the situation which will then arise is to pay out gold and gold certificates, and restore them to circulation.

This would have the effect of reducing the reserve ratio to a more manageable point. In an opposite situation, one in which the reserve ratio is low, gold could be retained when paid in by member banks and Federal Reserve notes issued to meet the general currency requirements.

Miller's suggestion is much more involved. He desires ${ }^{2}$ the Federal Reserve notes to become more similar to the issues of the Bank of England. If a larger gold reserve could be allocated for note issues, the reserve ratio for deposits could be made such as to render it safer to depend upon it. Calls by the public for more credits, calls which arise in time of rapid expansion, would reduce rapidly the reserve for deposits in such a way possibly as to justify efforts to restrict further advances. In this way the reserve ratio could be made a more workable guide.

Dr. Miller's suggestion is so important as to justify, perhaps, a somewhat extended quotation from his remarks. Speaking first of the administrative changes that need to be made he states:

The main change in the published weekly statement of the federal reserve banks that would be necessary would be to report the specific note reserve, held by the Federal Reserve Agent, and the specific deposit reserve held by the bank. The existing practice of stating the reserve position theoretically in the form of a ratio derived from a comparison of total re-

- "The Discount Policy of the Federal Reserve Banks," American Eca mamic Review, March, I921, p. 36.

Op. cit. 
serves with combined note and deposit liabilities should be discontinued, or, if continued, be given merely for purposes of theoretical comparison, by the federal reserve system, and a form of statement should be set up which would show the reserves actually held against deposits and notes respectively and separately, as the law contemplates.

The existing gold holding of the reserve banks should be reapportioned between the deposit reserve and the note reserve. To the deposit reserve might be allocated an amount of reserve money equivalent, say, to 45 per cent of their deposit liabilities as of the date when the new form of accounting would become effective. To the note reserve should be allocated all the remaining reserve, and, as the law requires, be in the form of gold.

The reserve thus allocated to the deposit reserve should be regarded as the working reserve of the banking or discount department of the federal reserve bank. The banks should be expected to conduct their discount operations on the basis of this reserve. Until conditions justified, the amount of this reserve should not be changed. Fresh accessions of gold received by the banking department should be transferred to the note reserve by way of substitution for other collateral held by the Federal Reserve Agent, or in exchange for federal reserve notes. Withdrawals of gold from federal reserve banks for foreign shipment should, for the present at least, be taken out of the note reserve by the presentation of federal reserve notes for redemption in gold or by the substitution of commercial collateral for gold in the security held by the Federal Reserve Agent. The deposit reserve held by the banking department would thus be fairly constant in amount; the note reserve, on the other hand, would be variable in amount, fluctuating mainly in accordance with changes in the international flow of gold, increasing when an influx was in progress and decreasing when an outflow was in process.

While the deposit reserve under the arrangement proposed above would be constant, the deposit reserve ratio would not be constant but would fluctuate. Any expansion of the loan account of the federal reserve banks would quickly reflect itself in the diminution of the reserve ratio below 45 per cent; any diminution of their loan account would quickly reflect, itself in an increase of the reserve ratio above 45 per cent. In brief, 
fluctuations in the reserve ratio would reflect quickly and accurately changes in the volume of the reserve banks' discounts.

From time to time the situation of the reserve banks as a whole, and of the several reserve banks individually, should be reviewed in the light of current credit conditions and needs in order to determine whether any reapportionment of reserves should be made; whether, e. g., any given bank should enlarge its deposit reserve at the expense of its note reserve. The modus operandi for effecting such enlargement would be for the bank in question to substitute commercial paper for gold as for collateral security pledged with the Reserve Agent for notes issued to the bank, the gold thus released being covered into the deposit reserve. So far as the bank's reserve position was concerned, this would be tantamount to the transfer of a certain amount of gold from the note reserve to the deposit reserve in order to give the bank an enlarged basis of lending.

Under this arrangement the reserve ratio would decline rapidly in an era of credit expansion. "It would be a faithful indicator of what was going on." It could be relied upon much more confidently than at present. At the same time, the public could anticipate with much more certainty future credit policy.

Adequate preparation, furthermore, would have been made for future outflows of gold to forcign countries. It seems impossible that the world's gold can continue permanently to be apportioned as inequitably as at the present time. Future withdrawals will likely be of enormous volume. Under Dr. Miller's plan the gold for these withdrawals would be conserved in the note reserve instead of having become demobilized by forming the necessary reserve for enlarged credit advances. This matter of making provision for future gold withdrawals, furthermore, might be accepted by the public as justilication for this proposed change much more readily than the desire to protect the system against future price inflation.

Although these suggestions represent mercly an attempt 
to remodel the Federal Reserve system more closely on the pattern of the Bank of England, they appear to the writer to deserve credit as a constructive proposal of great merit. It is particularly fortunate that they were formulated by a member of the Board.

But valuable as these suggestions may be, their adoption would not provide a complete solution. There would still remain the question as to just how great pressure should be exerted at any one time to keep the credit situation under control. How close to the legal minimum could the deposit reserve be permitted to sink without endangering its eventual sufficiency? And what would be the reply of the reserve administration if it were argued that its policy had been to the economic detriment of the country and that the gold earmarked as the deposit reserve had been made either too large or too small. In the final analysis the test of economic results must be applied to the reserve administration's acts. Making the reserve ratio a more accurate indicator will not accomplish everything.

The writer agrees with Miller and Leffingwell that there is no authority in the act for making price stability the test of discount policy. Neither would it comprise per se an infallible test from the standpoint of economic theory. High prices may be due to other causes than excessive issues of currency or credit. They may be due to physical causes of scarcity, scanty rainfall, depredations of insect pests, labor troubles, and a host of other factors. The remedy for such a situation would not be restricted credit. Rather, the difficulties due to such causes might demand extra advances from the banks. To enable the producers to avoid financial failure, it might be that the banks would be required to supply the funds necessary to meet current obligations. 
It has been mentioned previously that there are situa. tions in which slightly rising prices exert a tonic effect upon industry. Such a situation might be that following a period of subnormal activity. Federal Reserve policy should be adapted so far as possible to the requirements of productive efficiency and not to those of price stability. Over a series of years the volume of credit grants should be such as would lead to the maximum amount of production. The final test of the discount policy must be what production indices show regarding the effects of previous credit grants. If the curve of production is rising, there is justification for continued liberality. If past increases in the volume of credit have not correlated with an approximately corresponding enlargement of physical production, the situation, in the absence of other counteracting factors, calls for restrictive measures. To quote from a previous statement by the writer: ${ }^{1}$

Increase in the volume of rediscounts should be permitted so long as the main effect is to enlarge the volume of production and not to raise the level of prices. Decreases in rediscounts should be enforced when it appears that the volume of business and consequently the need for credit is declining. Over a long period of time increases in rediscounts should be apportioned to the natural rate of growth in the productive capacities of the people. To express the matter in terms of the equation of exchange $(P=M V)^{2} M$ should be altered when its principal effect will be borne by $T$ and not by $P$.

It should not be difficult to educate the public to this point of view. In every review of the month the proluction achievements of the country should be stressed promi-

'H. L. Reed, "The IVork of the Federal Reserve Board," Journal of Political Economy, January, 1921, p. 76 .

In this equation, symbol $P$ refers to the price level, $M$ to the amoun of money in actual circulation, $V$ to the rapidity with which the average unit of money circulates, $T$ the volume of trade for the period. 
nently. Attention should be called to the amount of credit advances for previous months and the attempt made to analyze their effects. Many would soon get in the habit of justifying credit advances according to their effect upon industrial activity. It should be seen that in a period of labor unemployment, of surplus stocks in the hands of producers and dealers, liberal bank loans may mean primarily the enlargement of production, the bringing on to the market of goods which otherwise would not be created. In an opposite situation, one of full labor employment, of shortage in supplies and materials, the effect of credit advances should be higher money terms on which business men bid for the scanty supply of goods, materials, and labor. Expansion then must mean price inflation.

In other words, the reserve bank which increases its operations should be made to defend its action on the ground that more credits were required to unlock unused productive resources. The writer is aware that the detailed rules for such a policy would call for a large measure of fine discrimination and that controversy must arise continually in their application. Nevertheless, there must be a correct formulation of the relation of increasing bank credits to the level of prices and the volume of trade. No ideal solution is otherwise possible.

It should not be difficult to find authority in the act for such a policy. The act states that rates should be fixed "with a view of accommodating commerce and industry." In so far as commerce and industry require the credits to function most efficiently, an attempt should be made to render them available. But if trade and production cannot be increased in approximately corresponding measure by use of a larger volume of credit, restrictive measures should be employed. It should be easy to secure assent to these principles by endeavoring continuously to lead the 
public to compare changes in the volume of proluction with those in the volume of credit and eurrency.

Decisions regarding the justification for increasing credits should be influenced also by qualitative considerations. In every season of unduly rapid activity certain excesses appear. Commodity and security speculation exceed past records, borrowers demand repeated renewals and loans of greater maturity, the liquidity of paper in general is reduced. By means of statistical comparisons: with the usual or standard conditions, aid could be had in ascertaining whether there is justification for permitting the volume of reserve bank advances to be enlarged.

At the present time there is a wide demand that as a permanent solution reserve banks' rates should be kept above the market rates. The argument is that the reserve banks should not contribute permanently any large part of the country's credit supply. The reserve banks' funds should be drawn upon only to meet extraordinary yearly or seasonal requirements. It is insisted that they should keep out of the market except in such situations. When a member bank rediscounts with a reserve bank, it should] do so only at a sacrifice. This, we are informed, is an accepted principle of central banking procedure. "Since I 87 I," for instance, "there has not been a single year when the official bank rate of the Bank of England was not above the market rate on yearly averages." s

A serious difficulty with this proposal is that of determining which of the various interest or discount rates should be taken as expressive of the gencral market rate. Should it be the rate on line-of-credit loans or should it be the rate on bank acceptances? Regarding this a Milwaukee banker states:

'Cf. "The Golk and Rediscount Policy of the Ferderal Reserve Banks," hy $\Lambda$. Barton Heplourn and Benjumin M. Anderson, Economic H'orld, July 23, 1921, p. I 12. 
The volume of line-of-credit loans in this country is far larger than the volume of bank acceptance credits, but it may be doubted whether the rates on such loans are as competitive as bank acceptance rates. Bank acceptance rates are fixed in the open market and are published. Line-of-credit loans are not as competitive as they may seem. A small firm commonly maintains a line of credit only at its own bank. Large corporations usually have lines of credit not only with their home banks but with large banks in financial centers, not necessarily because they can secure lower rates, but because no one bank wants to take care of their full needs. For these reasons it is to be cloubted whether line-of-credit loans afford as good an index of money market tendencies as the bank acceptance rates.

Although the acceptance rate may represent best the drift of the market, it might not be practicable to rely upon it. In many situations line-of-credit rates are far above the more competitive acceptance rate. A Federal Reserve rate based upon the acceptance rate might not have the anticipated effect of keeping the reserve banks out of the market except in emergency conditions. A reserve rate based upon line-of-credit rates, on the other hand, might remain too uniform instead of displaying the proper degree of flexibility.

It is believed, therefore, that no conscious effort should be exerted to make this the fundamental consideration. A rate fixed on the basis of preserving a reserve ratio, rendered manageable by the adoption of some such plan as Miller's, and modified according to production indices, ordinarily would be above the bank-acceptance rate. But as to how high above this rate it should be, this proposal ${ }^{2}$ gives no information. A reserve rate kept above all bank rates in all communities would, frequently at least, be too high to be workable. A reserve discount rate kept just

see IV. P. G. Harding, "Principles Governing the Discount Rate," The Annals, January, 1922, pp. 183-89.

'The proposal that reserve rates be kept above the general market rate. 
above the open market commercial paper rate might not be high enough to be effective.

The preceding brief discussion is designed to throw some light upon the question as to when reserve bank advances should be restricted. Let us next endeavor to ascertain the means which should be employed to restrict credits on occasions of necessity. Shall principal reliance be placed on rate increases? Or, will it be necessary to insist on direct rejections of applications on the basis of the quality of the paper offered? Or, finally, must greatest measure of attention be devoted to reserve banks' open-market operations?

There is much to be offered in behalf of reliance upon rate increases. It is the only means of restricting credit grants which does not subject the bank to charges of partiality. The general public undoubtedly has no adequate understanding of the pressure which is brought to bear upon the district directorates in such a period as that following the fall of 1919. Nothing can create more bitter criticism than the feeling that the bank discriminates unjustly against some portion of itscustomers. Particularly true is all this of the Federal Reserve banks. Their resources depend upon the contributions of all their members. Each member bank accordingly feels it has a claim upon the resources of the reserve bank on occasions of need. It is a requirement of policy that rate increases be made before other measures are attempted.

The efficiency of rate increases may be considered from two points of view. First, will a higher rate exacted by reserve banks be reflected in an increased loan rate by member banks? Secondly, will an increase in the general market rate discourage most largely desirable or undesirable business activities?

For a time a certain theory was current which, if true, 
would have denied the effectiveness of the ratc-increase method. Reliscounts create reserves for member banks. For every dollar of reserve money, member banks may loan six or seven or more dollars to their own customers. Since they receive interest on several dollars, must not the discount paid on the one dollar obtained from the reserve bank be a minor consideration? Any slight advance in rediscount rates would appear to be of little effect. To be really effective it would seem that the reserve banks' rates must be absurdly high, as, for instance twenty or thirty per cent. From the standpoint of commanding political support such a rate would be impracticable.

Answers to this puzzling question were several. Some argued that rate increases would be effective merely because most bankers had got into the habit of comparing the rates they receive on loans with the rate they paid on rediscounts. If the reserve bank rate was the higher, loans to customers would be reduced. It was held to be not so much a question of what bankers should think, but what they usually did think.

More complete analysis, however, would have indicated that there was little or no profit in paying a higher discount rate than that at which the funds were loaned. As a matter of fact banks cannot loan anything like six or seven or eight times the amount of credit obtained by the rediscounting operation. Inter-bank relationships render this impossible.

Suppose, for instance, a bank rediscounts sufficient paper to obtain a deposit credit of one dollar with a reserve bank. This one dollar of reserve money would enable the member bank to loan its customers, let us say ten dollars of deposit credits. In a short time, however, checks would be written against these deposits, and many of them deposited with other banks. In this way the other 
banks would receive the right to demand cash from the original bank. To meet these demands our bank would be obliged to give up cash or engage in further rediscounting. It must figure, therefore, if its reserve was insufficient originally, upon rediscounting almost as many dollars as it loaned its customers. Because of this fact, hanks would lose if they paid a rediscount charge very much greater than that received on their own loans.

It might be argued that the loss of cash to other banks need not occur if other banks were expanding their loans as rapidly as the bank we have in mind. Our bank woukd be receiving as many dollars of checks drawn upon other banks as they would receive against it. But if this were the situation, the loans of our bank prevent it from gaining cash through a favorable clearing house balance. Cash it might have gained in this way, upon being deposited with a reserve bank, would enable it to loan several fold its amount. The rediscount finally necessitated the cutting down of its loans to an approximately equal amount. Bankers were correct in refusing to admit profits unless they receive from their own customers approximately the same rate they pay to the reserve bank. ${ }^{\mathrm{T}}$

A second objection to the efficacy of rate increases is based upon the fact that many loans are exceedingly high, due to the fact that they are not subject to a high degree of competition. Many borrowers are unable to offer their paper outside their own community. In such situations the rates charged may represent some degree of monopolistic extortion. It is well known that in many newly developing sections of the South and West it is customary for banks to exact a charge of ten, twelve, fourteen per cent. As a matter of fact there may be some justification

${ }^{1}$ For a more elaborate discussion of this matter see Chester $A$. Pluillipa, Bank Credit, pp. I-76. 
for such high rates. The volume of business done in such communities may be so limited as to necessitate the allocation of higher ovcrhead charges to each dollar loaned. But, in such non-competitive situations, it would seem that an advance of a half per cent or so in rediscount rates might be a negligible consideration.

There is much to offer on the other side, however. It is questionable the extent to which the abuses of over-rapid credit expansion arise in such communities. Commodity and security speculation, the securing of capital for new industrial enterprises, in general the activities at the basis of a boom, are financed much more largely by funds obtained from banks in the larger cities where competitive conditions do prevail. With money dear in these places, unduly rapid industrial activity might be discouraged to a greater or less degree regardless of what takes place in the smaller localities.

By the application of the principle of progressive rates, moreover, banks even in these non-competitive communities might be made to feel the effect of the reserve bank's rate increase. Authority for the establishment of a progressive rate schedule has existed since the Phelan Bill became law on April 13, I920. According to the terms of this bill rediscount rates may be increased for those member banks whose rediscounts exceed a specified base line to which the normal rate applies. During the latter part of I920 effective use was made of this plan in two districts. In some cases member banks' applications were made as high as nine per cent for a portion of their borrowings.

The progressive-rate plan has not been highly popular, and during the period of its application there was a more or less general demand for its abolition. Some such measure, however, seems necessary if rate increases are to be made effective in communities where strong competition 
does not prevail. In situations demanding strict control of credit, inability to employ it may necessitate the use of other undesirable measures, such as the downright refusal to accept certain paper regardless of the amount of the cliscount that would be paid.

Many of the doubts regarding the effectiveness of rate increases are based upon the experience of the system during the latter half of 1920 during which reserve allvances increased despite higher rates. But so over-extended had most banks become in the preceding boom period that the process of liquidation was attended with great difficulty. There is general agreement that the rate increases of that year prevented the volume of advances from beconing as large as otherwise they woukl have been. It is not expected that many situations similar to those facing the reserve administration in the spring of I 920 will arise in the future. The credit and industrial situation at that time was intolerable. But it was due in large measure to the previous inability of the reserve banks to raise rates because of the Treasury's easy money programme.

It may be that the effect of rate increases will be most largely sentimental; that they are effective only in so far as they give hint of the determination of the administration to resort to stricter and more direct methods in the future. If this be true, it becomes necessary to develop standards for the application of methods designed to eliminate unessential paper. Such standards, however, should not be impossible of determination on the part of the district directorates. The former Directur of the Division of Analysis and Research of the Federal Reserve Board has suggested that the proper test is that of liquidity. He states: ${ }^{X}$

'See H. Parker Willis, "Discrimination in Inflation," Commercial and Financial Chronicle, September 11, 1920, pp. 1040-4l. 
If, for example, it should appear that a borrower had fallen into a way of business which required the extension of a longet and longer credit to customers, or that he was drawing upon securities of which he might stand possessed in order to protect, or collateral paper which he was keeping practically permanently in bank, or for which he was asking repeated renewals, the situation would be such as to raise a strong presumption against the essentiality of his borrowing.

But whatever the proper standards, they can be developed for use in situations where rate increases may not succeed in accomplishing their purpose.

In a brilliant article in the American Economic Review ${ }^{\text {x }}$ Miss Anna Youngman argues that the warning effect of rate increases cannot be sufficient unless it is known that the reserve banks possess the power to break local rates which remain high in spite of the discount policy of the reserve bank. She insists that rate increases cannot be effective if the local banks previously have been exacting much higher charges than those of the reserve banks. In such situations the warnings of the reserve banks will be ignored. Accordingly she advocates the extension of the open-market powers of the reserve banks to include the promissory note as well as the bill of exchange. If reserve banks were empowered to deal directly in the prevailing type of paper, they would be in a position to keep rates so closely in touch with those of the reserve banks that advances in the latter should prove more effective.

As mentioned previously, however, such a course would be politically hazardous. Nothing creates a greater degree of animosity toward the reserve system than the feeling that the district banks are competing with the member banks by using funds contributed by the latter. The weapons of the reserve system to-day are not perfect. But

"Issue of September, I921, pp. 466-85. "The Efficacy ot Changes in the Rates of the Federal Reserve Banks." 
it is believed they will be more powerful in ordinary situations than it is generally felt. As reiterated often, the reserve banks could exercise no real control over the loan market in the post-war boom period. Repuirements of Government finance were then the dominant considerations. Rather than increase the reserve banks' power to compete at all times more largely with member banks, it may be more expedient for the present to grant them further weapons in the use of their discount facilities. It may be preferable to permit them to "enforce reasonable regulations regarding usury or to refuse rediscounts to a bank that lends at extortionate rates." 1

The preceding discussion has emphasized the fact that an important question is the extent to which increases in reserve bank rates could be passed on to the business public. To what degree would higher rates discourage the public's demand for loans? It has been argued frequently that American business is commonly conducted on the basis of such liberal margins above cost that higher rates might not have the effect of limiting seriously the demand for credit. In the final analysis, however, all this would be a concern merely of the member banks. Member banks in the same manner as reserve banks desire to avoid direct refusals of loan operations. They would first proceed very likely on the basis of rate increases. But if the rate increases did not lessen the demand for loans, direct methods, however unpopular, must be employed. This, however, would not be a responsibility of the reserve hanks. It would be a problem solely for the member banks.

It may be true that rate increases would not be ideal in that they do not distinguish between socially desirable and socially undesirable demands for credit. Rate increases would impose the same handicap upon all regard-

- American Liconomic Keview, September, 1921, p. 478. 
less of the quality of the economic service rendered by the borrower. It may be true that higher rates can be withstood more easily by the borrower whose services are the least necessary to society. The margin of profit may be greater in the field of commodity speculation or in the sale of adulterated goods. But it is impossible for the reserve management to attempt to distinguish between the legitimacy of the various demands for credit. This, to repeat, is a problem primarily for the member bank.

It is not believed, therefore, that the time is ripe to grant further weapons to the reserve banks. What is most necessary now is that some means be found which will relieve the reserve banks from undue pressure to grant in the next boom period all the credits their present huge reserves would render possible. Two things in the writer's opinion need now to be emphasized. First, the reserve ratio should be made more manageable by transferring to the note reserves all reserve money except that which forms a workable basis for advances to member banks. Secondly, no opportunity should be overlooked to convince the public that an increase in the credit volume is defensible only when it is necessary to give full play to the country's productive powers. The effect of credit upon production should be most closely observed. Production indices should be given a position of prominence in every issue of the Bulletin.

The reserve system has been well managed. Although its policy has been developed in the stormiest years of American financial history, concessions have not been made destructive of its power and influence. Despite present attacks there is no doubt but that it has come to command the respect of the thinking American public. Bitter critics should remember that there has not yet been a period in its existence when the general situation would 
DEVELOPMENT, MAY, 1920, TO PRESENT 343 permit the formation of ideal policies for future credit control. The present, accordingly, is not the time to grant compromise to the advocates of easy money and cheap credit. The system must be fortified to mect the demands of the coming period of industrial revival. In that period will be tested the ability of the American people and of the reserve administration to adapt the powers of a wonderful financial mechanism to the requirements of presentday business and industry.

TIIE END 



\section{INDEX}

Acceptance, trade, development of, (Balances, minimum, $4^{6}$.

I05-27; bank, development of, Baltimore plan, the, 221 .

154-8.; foreign-trade and domes- Bank acceptances, essential function tic-trade, 169-71, 194, 195. Sie of, 154; in import trade, 155, 151): Bank, Trade.

Adanis, L. R., quoted on deducting exchange, 37,38 .

Advances, of rescrve banks, rediscounts, $7^{0-06}$; direct collateral, to member banks, 97-104: note issues, 205-20; of reserve bank deposits and reserves, $22 \mathrm{I}-38$. Sec Deposits, Note issues, Rediscounts, Reserves.

Agricultural credit, characteristics of, 128, I 30, I 32 ; restrictions on loans on real estatc, I28-30, I33, I34; need of commercial bank for farmers, 131, I32; provisions in Reserve Act relative to, $134-37$.

Agricultural paper, eligil,ility of, I $37^{-}$ 42 ; identification of, $1+2,1+3$; six-

months, rate of discount on, 146 , I 47.

Agriculture, legitimate ncels of, not neglected, I48-50; extent of hostility encountered by, 148. See Farmers.

Aldrich Bill, the, 2.

Aldrich-Vrecland Act, the, 22I, 222, 242.

American Acceptance Council, 12.3.

Anderson, 13. M., quoted on probability of decline in prices, 295.

Arbuthnot, l'rofessor C. C., quoted on banking resources, $7+$.

Asset currency, attempts to secure, 205-08, $22 \mathrm{I}$.

Atlanta Reserve Bank, and Supreme Court decision ronecrning cashing of cliectis, $36-38$. in export trade, $156-58 ;$ advantages of, 15 $5^{8-60}$; tyjes of transactions in which it is permitterl, 160,$162 ;$ restrictions on use of, I6I-65; conclitions governing use for permitted purposes, 165-60; forcign and domestic trade, identification of, I69-7I; classes of donestic, permitterl, $171-73$; restrictions governing power of reserve banks to accept, 17.3-75: syndicate acceptance, $\left.175^{-8}\right)$; policy in encouragement of use of, $180-82$; decline in, 182,$183 ;$ future development of, 183,184 .

Bank notes, issuing of, confined to reserve banks, 209; bond-secured, $2 I 1,212$; cause of increased circulation of, 212-14; Federal Reserve, and Federal lieserve notes, 213,214 ; issuance of, under $\mathrm{Al}$ drich-lrecland Act, $242,243$.

Bankers' acceptances, $19 \mathrm{r}$.

Bankers' loank, 1-3, 105 , 106.

Banking systems, of Europe and Ancrica, 107.

Banks, grerm of, in note issues and reposits, 205.

Barron, (". II., gunted on distrilmtion of funts, 24 ().

"liased on live stock," ruling of Board on, 1,37.

Bills of exclange, lefore the Civil II:Ar, 107: arlvamtages urgerl in ledealf of encouraging use of, $11 \mathrm{I}-$ 1.1: an epen-market paper, los. bunls, and bank notes, of natiunal. 
banks, 209-12; involve present hurden, 288, 289; prices of, 30Io3.

Book credits, 225, 237.

"Buy-a-Bale-of-Cotton" movement, 242.

Cable Transfers, 195.

Capital, definition of, 85,86 .

Cash reserves, ratio of, to net deposits and Federal Reserve notes, 276.

Central bank, fears of, 2 ; emergency character of, 6 ; arguments for and against, I05, I06; question of necessity of, I25; and bank note issues, 209.

Checks, collections and clearances of, importance of, 20; indicate need of continuous operation of reserve banks, 20; difficulties of, prior to I9I4, 21-25; indirect routing of, 22-24; exchange exactions, 25-28; provisions of act dealing with collections and clearances of, 28 , 29; means of absorption of charges, 29,30 ; methods of collecting and clearing, at first various, 30 ; voluntary-rcciprocal plan of clearances, 31,32 ; new system of clearances beginning operations July 15 , I9 16 , 33 ; attempts at coercion in connection with new system, 34-36; Supreme Court decision concerning method of cashing, 36-39; the Hardwick Amendment, 40, 4I; attitude of banks toward Board's clearance plan, 4I, 42; conclusions regarding par collections controversy, 45-49; extent of use of, 207.

Circulating medium, demand for, 208.

City banks and country banks, exchange exactions, 25-28, 45-49.

Clearances, check. See Checks, Collections.

Clearing house certificates, $2+3$.

Clearing house functions, and Federal Rescrve Board, 28, 29.
Clearing houses and clearing systems, before I9I $4,20$.

Collateral loans, 100-0.4.

Collections, check, difficulties of, prior to 1914, 21-25; provisions dealing with, 28, 29; voluntaryreciprocal plan of, 31, 32; new system of, 33; attitude of banks toward Board's plan of, 4I, 42; extension of system to time items, 44,45 ; conclusions regarding par collections controversy, 45-49.

Commercial bank, the farmer's need of, I31, 132.

Commercial paper, definition, 85,86 . Commodities, prices of, 278, 298. See Prices.

Commodity rate, $143-46$.

Contract for sale, 87,88 .

Coöperative credit institutions, I3r, I32.

Cotton, at time of Great IVar, 24I, 242.

Cotton loan fund, 242.

Country banks and city banks, exchange exactions, 25-28, 45-49.

Credit, regional system susceptible to expansion of, 5,6 ; principles of control needed, 19; agricultural, under the Federal Reserve, I2853; two forms of, note issues and deposits, 205; way open for expansion of, by amendment of June 21, 1917, 237; bank, on November 23, I917, 27 I 73 ; delayed process of war mobilization, 285 ; period of post-war expansion of, 292-3I5; and prices, as bearing on Reserve policy, 299-3II; and production 314,342 ; bases of control of, 32335; means of restricting, 335; and rate increases, $335-41$.

Credits, book, 225, 237.

Currency, volume of, relation to price level, 306.

Dairy cattle paper, I4I, I42.

Delano, F. A., quoted on purpose of reserve system, 248,252 . 
"Department store" banking, 68. Emergency relief, or continuous Deposits, a form of credit, 205; increase of importance of, 207 ; recognition of need of elasticity of, 208; demand and time, 223, 224; with reserve banks, methods of establishing, 224, 225; net, the law's definition of, 238 ; effect of, on prices, 306,307 .

Depreciation of the dollar, 200, 201 .

Discount, on ninety-day paper, rates of, 320 .

Discount operations, and openmarket operations, comparative volume of, 196; of newly established Federal Reserve banks, $2+5$.

Discount rates, acceptance and lineof-credit, 333-35. See Rates, Rediscounts.

Discountable paper, regulations regarding, 82- $\mathbf{5}$.

Discounts, direct, not permissible at first, 97 ; reasons for discrimination against, 97-99; arguments for, 99; amendment permitting collateral loans, roo; use of direct collateral loan, IOI, I02; advantages of direct loans, 102-07; in first years of the system, 253-57.

District directorate, responsibility of, 16, 17; and member banks, closeness of contact of, 18 .

Dollar, depreciation of, 201, 202.

Dollar exchange, 165, 166, 189, 203.

Domestic-tradc and foreign-tracle acceptances, 136, 169-71, 194, 195.

Double name and single-name paper, $75-82,107-11$.

Draft, in slow accounts, 109; trade acceptance in form of, 115,116 ; status of, for groorls to be used, 12 1; can be peldled, 136; for forcign tradle, $166-60$.

Draining and tilling, notes for, Ifo, I 4 .

Earning assets, 320 .

Edge Act, 177, 178, 180.

Elliot t, M. C., quoted, 122. operation, question of, 245-49.

European banking methods, anc! Anerican, 107.

Evans, Julge leverly D., his opinion concerning collection of checks, 38.

Exchange exactions, 25-28; means of absorbing, 20, 30; Mississippi law concerning, 35, 36; effect of Suprene Court decision concerning cashing of checks, 36-39; amil Hardwick amendment, fo, $f 1$; attitucle of hanks toward Board's plan, 4I, 42: legal warrant for, 43 . 44: conclusions regarding, $45^{-49}$. Export trade, use of trade acceptances in, $15^{6}-5^{8}$.

Farmers, discontent with reserve system, 15I-53. See Agriculture, Agricultural.

Federal Reserve Act, the llardwick amendment, 40,41 ; amendment of June 21, 1917, 66, 231-33, 237, 238, 263, 277; amendment of Septentber $7,1916,100,176,230$; provisions in, relative to agriculturil credit, 134-37; permitling mational banks to accept for (lomestic purpuses, 195; amemlunent of ceptember 17, I919, I76; andendment of December 24, 1919, 177: hecomes law, 240.

Feleral Reserve bank notes anul Fecleval Reserve notes. Ser dote issues, Notes.

Ferleral Reserve Banks, emergency character of, 6, 7 ; hegin operation, 24,245 ; questions of prolicy concerming, 24.5; for continuous operation, 245-40; earnings for 10 15 and 1016, 257, 25x; operalions, compared with those of private institutions, 25\%. Sie Reserve Banks.

Ferleral Reserve Board, and the question of resinnal responsilility, 16, 17; and liederal keserve Banks, 
I7, I 8; and clearing house, 28, 29; regulat ions of, regarding discountable paper, 82-85; appointnent of nembers of, 240; coöperated with the Treasury during the War, 2677o; coöperation with the Treasury a proper proceeding, 289-9) ; credit system of, 299, 307. See Credit.

Ferleral Reserve Clearing System, $278 \mathrm{n}$.

Federal Reserve System, district reserve banks the most eharacteristic feature; of, $\mathbf{I}$; the underlying theory of, 2; general considerations concerning admission into, $50-52$; national banks and, 52 ; conditions of membership in, for State banks, 52, 53; reasons for unwillingness of State banks to join, 5464; appeal for entrance of State Banks into, 65, 66; increased membership of State banks in, 67; considerations on State bank membership, 67-69; periods of, 239; not in operation at beginning of Great War, 243, 244; meant to operate continuously, $245^{-49}$; difficulties of getting into the market, 249-52; rate policy, 252, 253; discounts in first years, 25357 ; open-market purchases in 1915 and $1916,256,257$; statement of policy luring first period, 258-60; in the industrial depression of I920-2I, 320-22; future policy of, 322, 33I, 342, 343 .

"Float," 24, 25, 226.

Foreign branches, of American banks, $175,176$.

Foreign-trade and domestic-trade acceptances, 169-71, I94, 195.

Foreign Trade Financing Corporation, 179.

Gold, accumulating in reserve banks, 227-30, 235-37; in reserve banks, efficiency of, 233, 234; inflow of, 235; loldings of, increased, 237 , $264,265,275,276$.
Gold Settlement Fund, relation of, to inter-district shifting of funds, Io $n ., 29$; enlargement of functions of, 45; establishment of, 259; and . Iter-bank balances, $278 \mathrm{n}$.

Government bonds, I90, I94, $25^{\circ}$.

Harding, Governor, quoted on duties of Federal Reserve Banks and Federal Reserve Board, I7, I8; his attitude toward the Board's clearance plan, 42; opposed to plan of Senator Owen, 203; on Federal Reserve control of banking situation, 261; on notes, 270; on currency-volume and price level, 306.

Holmes, George K., 37, I30.

Implement paper, cligibility of, $\mathbf{1 3} 8$, 139, 142.

Import trade, use of trade acceptances in, 155 , I 56 .

Industrial reaction of $1920-21,316-$ 22.

Inflation, price, during the lWar, $278-8+$; due to method of financing the IVar, 284-9I; after the IVar, 295-99. Sce Prices.

Inter-district lending of funds, 9I4.

Investment operations of reserve banks, in 1917 and $1918,273,274$.

Investment paper, objections to rediscount of, $72-75$; criterion of, $85-93 ;$ and open-market operations, I9o.

Investment trust, 177.

Irrigation, I9I.

Jones, Mr., of the Federal Reserve Board, 240.

Kemmerer, Professor E. W., Izo.

Leffingwell, R. C., quoted, on rates, 301-03; on reserve ratio, 326,327 . Live-stock paper, I37, I38, I4I, $1+2$. 
Loans, collateral, I00-04; real estate, National and State, restrictions on, 128, 130, 133, I34; effect of rates on, $3+1,3+2$.

McAdoo, Secretary, quoted on entrance of State banks into Federal Reserve System, 65.

Member banks, and district directorates, I8; State banks, 50-69; arlvances to, in form of rediscounts, 70-96; direct collateral advances to, 97-10.4; restrictions on their power to accept bank acceptances, 167-73; and redemption of bank notes, $215^{-17}$; reserves of, 2222.; methouls of estal,lishing deposits with reserve banks, 224 , 225; and book credits, 225; reserve percentages for, 225-27, 232, 238; legal reserves of, to be hetel entirely on deposit with reserve lanks, 231, 232,263 ; and the question of capital stock subscriptions, 250-52; conditions of, in serond period, 265, 266; reserve account of, in I917 and I0Is, 27t; effect of II'ar on operations of $276,277$.

Miller, A. C., quoted on wages and cost of living, 305; his plan of credit control, 325-30.

Mississippi law, as regards exchange, 35,36 .

Mitchell, Professor W'estey C., 279.

Mortimer, lirank C., quoted on return of capital stock subscriptions, $25^{\circ}, 25^{1}$.

Moulton, Mr., quoted, 79.

Municipal lond!s, 194.

Municipal warrants, 250.

National banks, membership of, 52; legislation broalening powers of, 68 ; bonds and bank notes of, 20012. 220.

National Reserve Association, 2.

Net eleposits, the 12w's defintion of, 2.38.

Note issues, a form of credit, 205; developed before deposits, 206; subject to strict regulations by National Banking Act, 200; elasticity of, 2os: concentrated in hamis of rescrve bauks, 200): of Ferleral Reserve notes, 21 it methorl of, 21.-10; ditect of, on prices, 306,307 .

Notes, bank, issuing of, confinerl to reserve banks, 209); bomb-secured, 2I , 212; cause of increaserl cirrulation of, 212-14; isstued to replare standard silver dollars destroyed, $21.3 ;$ issuance of, umeler AldrichVreeland A.t, 2.42, 2.43.

Notes, farmers', 137-42. See Agricultural credit.

Notes, fecteral Reserve, issuance of, hy Act of 1913,21 t reveivalule by menler and reserve lanks, 215; lien luehinel, 215; issued through rediscounts, 215, 216; return of, 216,217 ; interest charges on, 2I7; outstanding of, 2I8-20; most important element in our general circulation, 220: made more acecplable by amendment of Sepr)temler 7,11$) 16,231$; sulistitution of, for gelde 235 ; to be coumed as part of rault reserves, 2,36 ; late place of legal temler, 237 ; chimges in circulation of, for varions dates, $27+320$; grolel cover for circularion of, 275 ; elfect of, on prices, 306 , 307.

Open book account system, ios.

()pen-market operations, and discount operations, difference between, 1,55-87; rextension of, (1) reservo bianks, 1s5; reilsouss for inclusion of, in linul lill, 18,- hes)

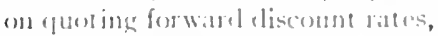

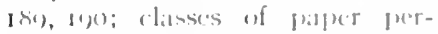
minfol in, Jun, (1)1; as regards

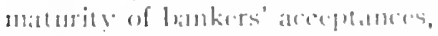
11)2, 19.3; as rekints cloalings in calde transfers amel gold roin am bullion, I93; ats regarits purchase of 
acceptances, 194, 195; comparative volume of, I96; objections to, I96-200; proposal for separate reserve bank, 200-04; during 1915 and $1916,25^{6}, 257$.

Organization Committee, 2 . 0.

Owen, Senator, quoted on abrlication of Board, I6; his proposal for separate reserve bank, 200-04.

Perrin, John, quoted on direct discounts, 98 .

Phelan Bill, 338.

Pittman Act, 2 I 2-I 4.

Prices, wholesale, rise of, in period $1917-1918,278-80$; retail rise of, in period $1917-1918,279,280$; relationship between media of exchange and, $280-82$; results of, 282-84; due to method of financing the War, 284-9I; after the War, 295-99; relation of, to volume of currency: 306 ; factors determining, 307 ; and bank:credits, 308-I I; as affected by enlarged money demand, 309 ; in industrial reaction of, 1920-1921, 316-22; stability of, as test for rediscount policy, 324 , $325,330-32$.

Production, as guide to future Federal Reserve policy, 33I-33; and credit, $3+2$.

Rates, 5-7; commodity, I43-46; discount, quoting forward, i 89, I90; policy of Board in regard to, marked by conservatism, 252, 253; on commercial paper, increased, 263, 264; from Nay, I9I7, to November II, I9I 8 , 268-70; rediscount, 303-05. 3III5; of discount on ninety-day paper, 320; of reserve banks, and market rates, 333; acceptance and line-of-credit, $333,33+$; reliance on, as means of restricting credit (progressive rate plan), 335-4I; effect of, on demand for loans, $341,342$.
Real estate loans, National and State restrictions on, $\mathbf{1 2 8}, \mathbf{I} 30$, I33, 134 .

Reclamation districts, 191.

Rediscounts, coöperative function of reserve banks, 70, 7I; provisions regarcling, 71, 172 ; of speculative and investment paper, objections to, 72-75; single-name and doublename paper, $75^{-82}$; regulations regarding rliscountable paper, 8285; determination of eligible paper, 85-93; the question of limitations, 93-96; and direct discounts, 97,98; rate of, on six-months agricultural paper, 146 , I 47 ; no great demand for, at first, 250 ; rates of, $303-05$, 3I I-I 5 ; control of, essentials should be developed, 322; policy, reserve ratio as guide for, $324,325,327-$ 30; policy, price stability as test for, $324,325,330-32$; increase in rates of, as means of restricting credits, 335-4r.

Reed, H. L., articles of, quoted, 286 , $287,309,33 \mathrm{I}$.

Regional banks, system of twelve, 2 . Regional responsibility, I6, I7.

Regional system, surprising outcome of legislative planning, I; statement of objections made to, 3-5; consideration of objections to, 5I 8 ; and credit expansion, 5, 6; and continuous functioning, 6, 7; and rates, 6,7 ; and sectionalism, 8 ; and inter-district harmony, 9-14; and complaints of sectional partiality, 14-16; and regional responsibility, 16, I 7; merits of, 18; most vulnerable point of, 18 .

Renewal trade draft, 122.

Reserve account, of member banks, 320.

Reserve bank, proposal for separate, 200-04.

Reserve banks, and check collections and clearances, 20-49; advances of rediscounts, $70-96$; condition governing the power of, to acquire 
acceptances, 173-75; open-market operations of, 185-204; advances of, note issues, 205-20; advances of, deposits and reserves, 221-38; their bank credits with menber banks, 225; reserve percentages for, 225; efficacy of gold in, 233, 234; and the question of capital stock subscriptions, 250-52; reserves of, 264; investment operations of, 273, 27t; earning assets of, 274 ; ratio of cash reserves to net deposits and Federal Reserve notes, 276; relation of, to other parts of system, should be formulated, 322; surplus reserves of, cnormous, 323; rates of, 333-35. See Federal Reserve Banks.

Rescrve clearing sy'stem. See Checks.

Reserve funds, used for speculative purposes, $15 n$.

Reserve percentages, 225-27, 238.

Reserve ratio, changes in, 298,320 ; as a guicle for rediscount policy, 324-30; should be made more managealsle, $3 t^{2}$.

Reserves, of nicmber banks, 222-24; percentages for reserve and member lanks, 225-27; gold, 227-30; to be held entirely with reserve banks, 231, 232; surplus of reserve banks, 323 .

Reynolds, Arthur, 246.

Sectionalism, and the regiosal plan, 5, 8-14.

Senatorial Banking Committee, 240.

Short-time paper, in open-market operations, 190 .

Silver dollars, melting down of, in accordance with Pittman Act, $212-14$.

Single-name and double-name paper, $75^{-82}$, I08-II.

Speculation, reserve funds used in, $15 \mathrm{n}$; land, 133, I34, I5I; boon, 315.

Speculative paper, objections to re- discount of, 72-75: criterion of, 85-93.

Sprague, O. M. W., quoted, 80, 324.

State lanks, conditions for membership of, in the Federal Reserve System, 52, 53; unwillingness of, to join Federal Reserve Sy'stem, 54; doubtful legal position of, 55, 56 ; question of double liability of, 56 ; on rediscountability of paper held by, 57-59; other reasons for unwillingness, 59-64; increased membership, 65-67; considerations on membership of, 67-69.

Stewart, Walter IV., 280.

Stokes, E. C., quoted, 310,3 II.

Strong, Governor, 58, 219.

Syndicate acceptance, $175^{-80}$.

Ter Mculen, 180 .

Thralls, Mr., quoted on the Hardwick Amendment, 40.

Timber, 86, 87 .

Time items, collection department for, 44,45 .

Tractor paper, 138 .

Trade acceptances, opcrating in same mamer as check, ron); advantages urged in belalf of encouraging use of, 11I-It; means employed to extend usc of, II5: origrin as distinct class of commercial paper, I I5; qualifications to which it must conform, 115, I16; why drawn in form of draft, 116 ; comparative amount of, discounted, 117; obstacles in the way of wide extcnsion of its use, i1820; aid to, justified, I20; objectionable nethods of using, 12023; in renewals, 122; on strength of firms whose allegiance 10 , was sourht, 123, 12.; used relatively infrequently, 125: limitations regarding anount of, 125-27.

Trade credit, historical catuses of present methorls of, 107.

Trumle paper, provisions pertinent to, 110 . 
Treasury certificates, short-term, issues of, in the WVar, 267, 268; shorttime fiscal requirements of, 300 .

Two-name paper. See Double-name.

Wages, 305.

War, the Great, effect on finances, 240-42; effect of, on operations of nember banks, 276, 277; conditions following, 292-97.

War finance, successful and unsuccessful, 284-9I.

Warburg, Paul M., 65; quoted on trade acceptances, 80,81 ; on the contrast between European and American banking methods, 107; on trade acceptances, il 8, I19; on quoting forward discount rates, I 89; on the storing of gold, 228; his appointment to Federal Rescrve Board, 240.

Warrants, 194, 250.

Williams, John Skelton, quoted on speculative use of reserve funds, 15 . Willis, H. P., quoted on central bank, 8 .

Wilson, President, 240.

Withers, Hartley, 244.

Youngman, Anna, her objection tu open-market operations, 196-200; on rate increases, 340 . 





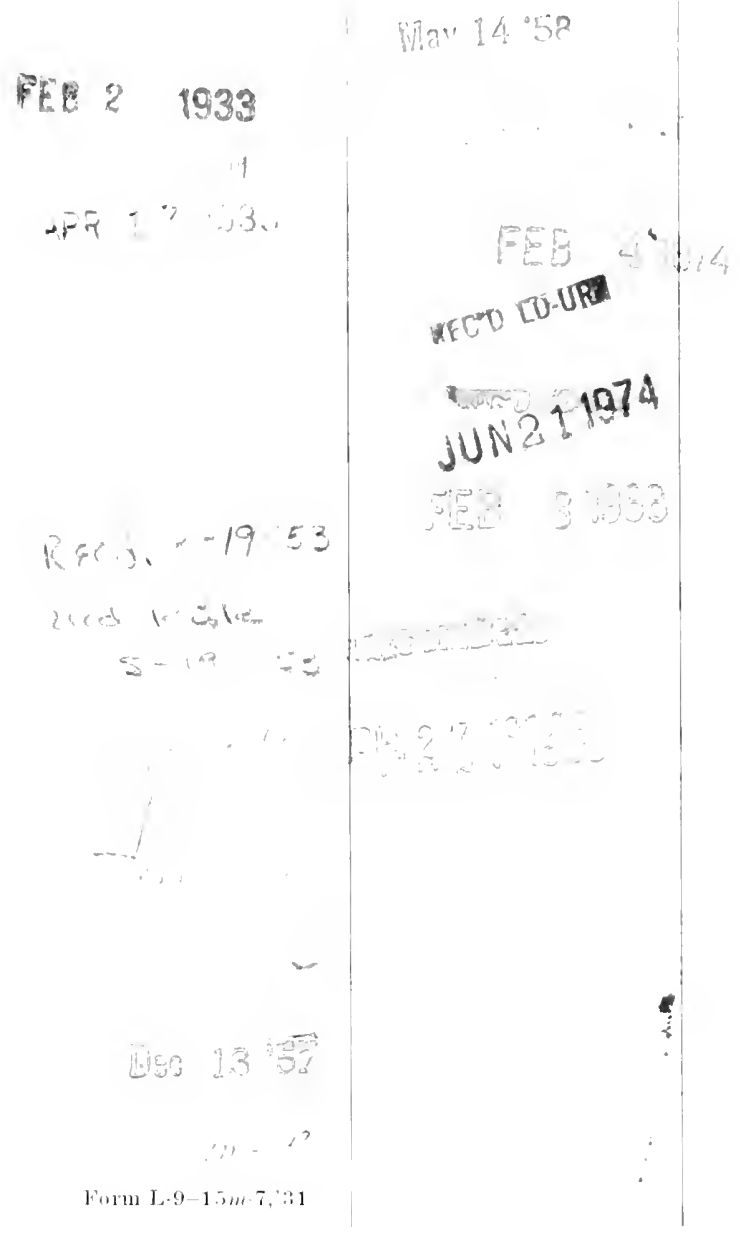


